\title{
O XAVANTE E A POLÍTICA INDIGENISTA NO BRASIL NOS SÉCULOS XVIII E XIX
}

JOSÉ CLAUDINEI LOMBARDI

Orientador: ORIOWALDO QUEDA

Dissertaçāo apresentada à Escola Superior de Agricultura "Luiz de Queiroz", da Universidade de São Paulo, para obtençāo do título de Mestre em Agronomia. Área de Concentraçāo: Sociologia Rural. 


\title{
AGRADECIMENTOS
}

\begin{abstract}
Assim como todos os demais aspectos da vida, este trabalho näo poderia deixar de ser fruto do trabalho coletivo, tanto do produto do trabalho que nos legaram as gerações que nos antecederam, como daqueles que partilharam os caminhos ou descaminhos que o atual momento histórico nos propicia。

Aqueles que me antecederam, sua contribuição já faz parte da história, restando-nos utilizar de sua produção; aos que participaram mais ativamente para o meu entendimerto da questão indígena, ou que viabilizaram o presente trabalho, quero, pelo menos, fazer o registro de seus nomes.
\end{abstract}

- Aos índios Xavante, não somente porquue me possibilitaram algum tempo de convivência entre eles, mas por terem me ensinado a romper com os estreitos limites do conhecimento acadêmico e ver, sentir e entender que a problemática da população indígena, existe e tem sentido no contexto histórico em que se insere. Ainda que tardiamente, quero registrar meu profundo respeito ao grande líder que foi Apowẽn, exemplo de perspicácia histórica e de condução política de seu povo, encarnando, 
como poucos, o exercício do poder coletivo em benefício dos seus.

- Aos companheiros indigenistas, ou que por força de circunstâncias atuavam no indigenismo, quero evidenciar que nossas longas conversas noites a dentro, nas aldeias e nas cidades, através das quais se buscava entender a problemática do índio e novas formas de ação j.ndigenista, em que a própria população indígena fosse agente histórico de seu projeto político, não ficaram relegadas ao esquecimento. Na verdade, foi toda a angústia que compartilhavamos que acabou sendo a mina de onde fluíram as idéias básicas de meu projeto de pesquisa e do presente trabalho. Aos companheiros Odenir Pinto de Oliveira, Izanoel dos Santos Sodré, Claudio dos Santos Romero, José Carlos A.lves, Maristella sundfeld e Isaac Bavaresco, com quem pude um aia compartilhar a preocupação pelo destino dos índios, meu sincero agradecimento fraterno。

- A Missão Salesiana de Mato Grosso e, mais particularmente, às Missões de Meruri, Sangradouro e são Marcos, que tantas vezes soube me acolher e possibilitar as condições para a pesquisa e ação indigenista. De modo pessoal, saliento a cordialidade, a atenção e a possibilidade de um conhecimento mais profundo sobre os Xavante à Bartolomeu Giaccaria e Adalberto Heide, ao Pe. Marinoni e ao Pe. Miguel, e, de modo especial, à Irmã Joana D'Arc e ao Pe.Clemente. Com essas pessoas aprendi que muito acíma da mera ação profissional, está um profundo comprometimento com a causa indígena e com os destinos de um mundo.

- Aos professores do Departamento de Economia e Sociologia Ru 
ral, da Escola Superior de Agricultura "Iuiz de Queiroz", da Universidade de são Paulo, pelo acolhimento ao programa de pós-graduação e pela contribuição prestada à minha formação intelectual. De modo especial, agradeço ao Prof. Oriowaldo Que da, não somente por ser meu orientador, mas por sua amizade e efetiva participação na discussão do projeto de pesquisa, indicação bibliográfica, discussão dos pressupostos básicos trabalhados, paciente leitura dos originais e às imprescindíveis sugestões que acabaram por tornar viável este trabalho.

- A Miguel Nakamura, não simplesmente por reconhecer sua amizade e companheirismo, mas registrar a profunda contribuição que me deu para delinear a problemática da pesquisa, o estudo e trabalho conjunto na busca de estabelecer os pressupostos teórico-metodológicos que permitissem a compreensão das questões tratadas e a participação ativa nas pesquisas preliminares para que se testasse a adequação (ou não) das análises.

- A Instituição de fomento à pesquisa e pós-graduação que me possibilitou o sustento durante o período de mestrado - o C.N.Pq. - a minha gratidão e ao mesmo tempo meu profundo desejo por ver transformada a política de pesquisa no Brasil.

- Aos colegas da Universidade Estadual de Maringá, que do inte rior mesmo das profundas contradições da vida acadêmica, principalmente das refletidas por uma estrutura universitária, acabaram possibilitando as condições para a redação final deste trabalho. De modo especial, àqueles companheiros com quem pude discutir as questões teórico-metodológicas norteadoras de nossa produçăo acadêmica; àqueles que pacientemente leram os escritos originais e forneceram preciosas sugestões; aos que pacientemente fizeram a revisão metodológica e ortográfica do 
trabalho final e as traduções necessárias: Ermelindo Tadeu Giglio, Guaraciaba Aparecida Tullio, Jean Vincent Marie Guhrur, João Carlos Catalão, Lízia Helena Nagel, Luiz Carlos da Gama, Mario Camargo Pego, Romilda Marins Correia, Sandino Hoff e Zélia Leonel.

- A Maria Saleti, por sua disponibilidade em contribuir na datilografia do trabalho final.

- Finalmente, ao companheirismo da Ivone, não somente no dia-a-dia, mas no acompanhamento aos trabalhos de campo, na redação dos relatórios de pesquisa, na datilografia dos maniscri tos e trabalho final. Também àqueles que a todo momento me renovam a esperança em viver: Maíra, Warody e Araê. 


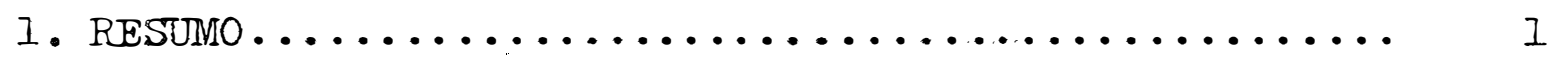

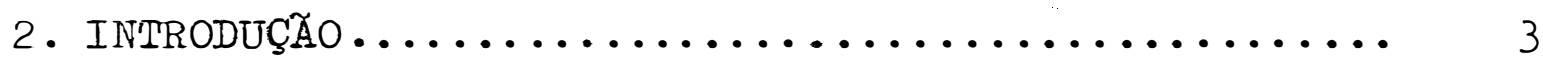

3. A QUESTÃO INDIGENA E O DESENVOLVIMENTO DO CAPITALISMO NO BRASII COLÔNIA.................. 35

3.1. A Formação Econômica Brasileira: a Economia

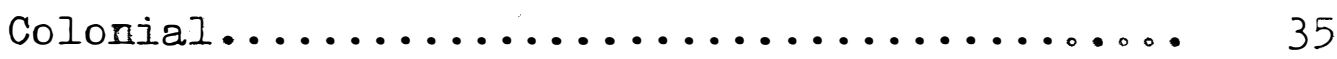

3.2. A Política e a Prática Indigenista no Período Colonial......................... 48

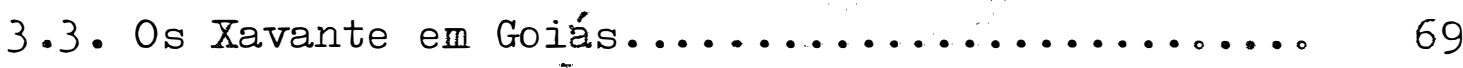

4. A ECONOMIA MERCANTIL-ESCRAVISTA NACIONAI......... 82 4.1. Caracterização Geral da Passagem da Economia Colonial à Economia Mercantil-Escravista..... 83

4.2. Passagem da Economia Colonial à Economia Mercantil-Escravista no Brasil.............. 93

4.3. A Economia Mercantil-Escravista Cafeeira Nacio nal........................... 103

4.4. A Crise da Economia Mercantil-Escravista e a Emergencia do Trabalho Assalariado.......... 122 
4.5. Desdobramentos da Economia Mercantil-Escravista e outros Aspectos da Economia Nacional....

5. A POLITICA E A PRÁTICA INDIGENISTA DURANTE O PERIO-

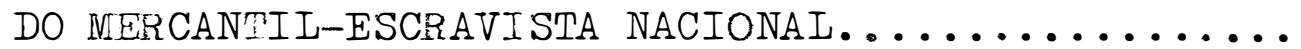

5.1. A Política Indigenista no Período Mercantil-ES cravista Nacional.................. 147

5.2. A Situação Indigenista no Centro-0este...... 210

6. OS XAVANTE NO SECULO XIX.................. 251

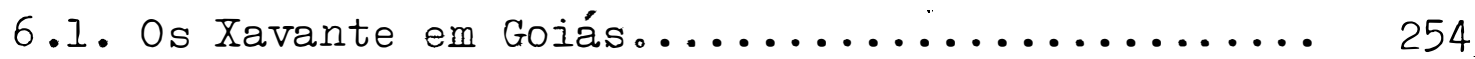

6.2. Os Xavante em Mato Grosso............... 274

6.3. A Questão da Origem Tribal dos Xavante....... 300

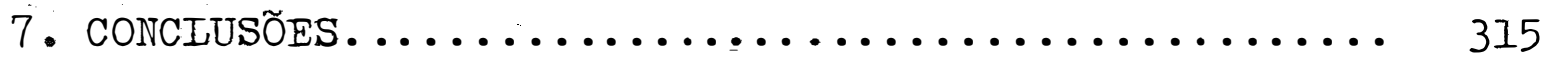

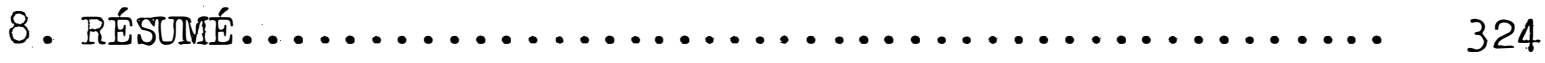

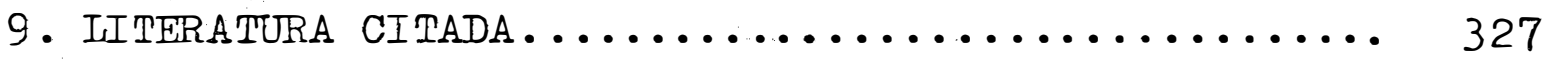

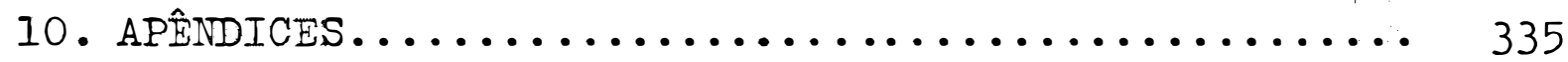

Apêndice I - Legislação Indigenista do Período Cole

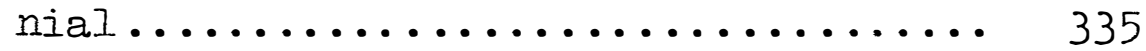

Apêndice II - Legislação Indigenista do Período Mercantil-Escravista Nacional...... 345

Apêndice III. Relato da "Primeira Pacificação" dos

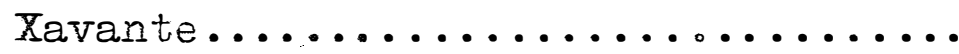


1. RESUNIO

Título: "O XAVANTE E A POLITICA INDIGENISTA NO BRASIL NOS SECULOS XVIII E XIX". Autor: José Claudinei Lombardi. Orientaaor: Prof. Dr. Orjowaldo Queda.

Esta dissertação é um estudo das condições históricas de insersão dos índios Xavante no processo de desenvolvimento do capitalismo no Brasil, que conduziu às seguintes conclusões: Tratar as sociedades indígenas de forma autônoma constitui uma distorção da realidade, pois os indígenas sè inserem r.o processo de desenvolviment;o do capitalismo no Brasil.

O caso dos Xavante evidencia que a expansão da colonização fez com que os índios formassem uma ccrfiguração sccial dependerte dos interesses dos colonizadores. A supremacla esestes imprimiu às relações entre índios e brancos um caráter essencialmente colonial, sendo regida pela oposição etnia colonizadora/ etnia colonizada, que norteou a submissão dos Xavante acs interesses coloniais e, depois, necionais. Estes prccessos representaram a subordinação das populações indíge- 
nas aos interesses do capital.

Isto não significou, porém, a destruição da identidade social dos indígenas, que permaneceram considerando-se e sendo considerados como índios. A inserção dos Xavante na estrutura global capitalista se deu quer enquanto grupo social pertencente ao segmento mais inferior da estrutura de classes, quer enquanto categoria social diferenciada, embora dependente. Mesmo sofrendo o violento processo de expropriação de seus meios de produção e o extermínio de parcelas de sua população, os Xavante continuaram a produzir e reproduzir as condições para continuar a ser Xavante, mantendo sua identidade tribal.

Esse processo exigiu que os Xavante continuamente construissem e reconstruissem sua identidade tribal, o que implicou a síntese dos vários elementos contraditórios que compõem o mundo tribal e o capitalista, elaborada pela reinterpretação das situações históricas que os envolviam.

o capital tende a impôr às demais relações de produção sua categoria e importância, o que não elimina suas coñtradições, sendo que é nesse espaço que se realizam as condições de subordinação/resistência das relações de produção não-capitalistas à forma de dominação do capital. A resistência indígena não se caracteriza, assim, por sua aparência, mas pela conservação de uma estrutura econômica não-capitalista, que se opõe à penetração do capital. Isto não indica a constituição de um ou mais modos de produção sob a dominância do capital, mas uma luta específica dessa categoria social, que procura manter a sua existência como índio. 


\section{INTRODUÇÃO}

A presente dissertação é parte de um amplo projeto de pesquisa sobre os Xavante, através do qual se busca recuperar a totalidade do processo histórico por que passou esse grupo tribal em face do desenvolvimento capitalista brasileiro. Até o presente, a pesquisa abrangeu o período compreendido desde a economia colonial à mercantil-escravista nacional (século XVI ao XIX), estando redigido, mas não publicado, - relatório de pesquisa (IONBARDI, 1985). Este projeto me acompanha desde 1972. Na época, estridante de Ciências Sociais, entusiasmei-me pela antropologia. O resultado foi a participação em um projeto quie estava sendo desenvoIvido pela FAFI de Rio Claro, junto aos índios Xavante da Reserva Indígena de Cou to de Magalhães. Tratava-se de um projeto de "desenvolvimento comunitário", eminertemente intervencionista e paternalista, cujos resultados práticos logo se mostraram inadequados para enfrentar a problemática que esse grupo tribal vivia.

Acreditava-se, na época, que o fracasso adveio da pouca compreensão que se tinha sobre os Xavante, sendo necessários estudos mais profundos da estrutura e organização do 
grupo, bem como da relação entre as diferentes etnias envolvidas.

Essas impressões acompanharam-me durante algum tempo, até que, ao terminar a graduação em 1976, recebi e aceitei o convite para trabalhar, como um dos antropólogos, em um novo projeto que estava sendo desenvolvido junto a esse mesmo grupo tribal (Xavante). Esse novo projeto abrangeu todas as aldeias e reservas indígenas dos Xavante, e mais as aldeias Bororo da Reserva Indígena de Meruri (Memri e Garças), sendo financiado pela FUNAI e administrativamente subordinado a ela. Em termos práticos, o projeto pretendia que se reduzissem os problemas sofridos pelos Xavante, fazendo com que este grupo deixasse de constituir-se um dos principais entraves ao Orgão Tutelar, principalmente junto à opinião pública e imprensa. Os instrumentos que estavam à disposição do projeto, principalmen te recursos para atender a reivindicações supérfluas ou que promovessem incremento e mudanças na estrutura produtiva, acabavam resultando num aumento da dependência dos índios em relação às instituições intervencionistas (à FUNAI e à Missão Salesiana). Objetivamente, o projeto cumpria muito bem o papel que cabia à FUNAI: ser meio de "integração" dos índios à sociedade nacional, ao mesmo tempo em que abria suas terras à exploração dominada pelo capital.

Ocorreu, porém, que alguns membros da equipe não se sujeitaram às determinações emanadas pela FUNAI, somando seus esforços aos dos próprios índios, sobejamente conhecidos por suc profunda resistência ao proçesso de penetração e ocupação econômica, social e cultural da sociedade nacional.

Tal situação levou a uma burocratização do projeto, submetendo-o à estrutura administrativa e funcional do 
Orgão Tutelar. Com isso, a equipe de trabalho se esfacela e do final de 1978 a 1979, passei a atuar junto a outros grupos tribais no sul do país (Kaingang, Guarani e Botocudo)。

Esse período de atuação na FUNAI, de 1976

a

1979, permitiu-me o conhecimento da situação de alguns grupos tribais (Xavante, Bororo, Karajá, Tapirapé, Kaingang, Guarani e Botocudo), além de contatos com muitos outros. Isso contribuiu para que me desse conta, na prática, de que somente o conhecimento do tipo etnológico não era suficiente para que se entendesse a realidade indígena. Não nego a contribuição que os estudos descritivos trazem ao conhecimento da problemática indígena, porém esta tem que ser inserida num contexto mais amplo: no processo de desenvolvimento do capitalismo no Brasil.

E na busca de entender a questão indígena no contexto do desenvolvimento do capitalismo no Brasil que o presente trabalho se insere. Dada a amplitude do tema, restringe-se o seu alcance à concentração de um único grupo tribal: os Xavante. A escolha dos Xavante como objeto de estudo deve-se não só ajo fato de ser o grupo que melhor se conhece, mas também por sua representatividade no debate da problemática indígena e resistência histórica à penetração do capitalismo na região centro-oeste do Brasil.

A presente dissertação apresenta os primeiros resultados das pesquisas que venho realizando e que tratam a questão indígena e o desenvolvimento do capitalismo no período mercantil-escravista nacional, buscando entender como os interesses do capital, instrumentalizados na política e na prática indigenista desenvolvida ao longo desse período, afetaram historicamente os índios Xavante. 
Antes de mais nada, é preciso que se entenda que ao longo da história do Brasil, que é a história da expansão e do desenvolvimento do capitalismo, as relações entre índios, por um lado, e "brancos", de outro, têm-se caracterizado pelo conflito, tendo por palco principal a luta pela posse da terra. O problema tem que ser encarado sob o prisma dos envolvidos: para os índios, os brancos liquidam as últimas possibilidades de uma vida autônoma ao invadirem seus territórios tribais; para o branco, a questão se coloca em termos de não ser possível parar com a expansão e o desenvolvimento da civilização, onde o Índio aparece como aquele que domina terras virgens, férteis e abundantes em recursos, criando dificuldades para que as terras, por eles ocupadas "improdutivamente", sejam ocupadas e possibilitem a realização da acumulação de capital para a promoção do desenvolvimento (LOMBARDI, 1983, p. $24-25)$.

Pela visão que se tem da questão a nível do senso comum, na literatura e mesmo nos textos didáticos usados nas escolas, pode-se apreender adequadamente o sentido desta ideologia dominante: entre a população situada nas áreas geográficas em que o capitalismo inicia sua penetração (zonas de garimpo, de instalação de empreendimentos agro-pecuários e de abertura de estradas), o Índio é considerado como a fera indomada, o selvagem matador de pobres inocentes, 0 vagabundo que nada produz... Já no ambiente urbano, e também no escolar (vejam-se os textos didáticos, por exemplo) o índio é tratado de modo romântico: é a imagem do bom selvagem, do homem do corpo perfeito, dentes bonitos e fortes, cheio de pureza, sem maldade e em perfeita integração com a natureza (NOSELLA, 1981, p. 191-198). 
Há os que fazem esforço para compreender a problemática indígena, mas acabam parando na superficialidade, nos aspectos aparentes: a descrição da situação de miséria de muitas aldeias; a falta de proteção da FUNAI, caracterizada como órgão que não cumpre seu papel de tutor; an falta de assistência (econômica, no campo da saúde e da educação); a situação de mendicância de miitos povos indígenas, etc。

Mesmo reconhecendo que esta última posição revela muitas situações reais a que se tem submetido historicamente a população indígena e seu mérito em denunciá-las junto à opinião pública, falta-lhe uma análise profunda das causas que geram em seu conjunto a questão indígena。

Tendo-se como pressuposto uma concepção que procura recuperar a totalidade de nosso mundo e de nossa sociedade, essas formas de apresentar a questão indígena não passam de aspectos diferentes da ideologia dominante. Enquanto tal, revelam posiçoes contraditórias e conflitivas: ora o índio é apresentado de forma romântica, como pessoa feliz e que vive num mundo onde tudo é belo e harmônico, amigo e fiel colaborador do branco; ora é apresentado como selvagem, capaz de guerras terríveis e cruéis, animal alucinado que não sabe bem o que faz. Normalmente essas concepções e narrações são apresentadas com um caráter impessoal, neutro, aparentemente sem um julgamento de valor, determinada pela concepção de mundo do "homem branco", a cultura que pretende se constituir no máximo da vida humana em sociedade: a civilização ocidental e cristã (NOSELLA, 1981, p. 191-192).

Sabe-se, porém, que os julgamentos de valor não podem ser descolados da totalidade social em que são engendrados, e que, por isso mesmo, a questão indígena, tal como é re- 
velada pela forma de pensar dominante, está carregada dos conceitos pré-concebidos presentes na concepção civilizadora de nossa sociedade. Nesta, os "brancos" são apresentados enquanto os possuidores da. verdadeira civilização e os índios ignorantes que precisam ser domesticados. O denominador comum que caracteriza uma ideologia dominante, reside no fato de que apresentam uma falsa realidade, através da qual fogem à verdade incômoda de ter-se que reconhecer que a práxis sócio-econômica da sociedade brasileira, por ser classista, é de exploração. Exploração que só é possível quando uma classe se outorga - direito de se constituir como dominante (IOMBARI, 1983, p. 25).

Se se continuam ignorando alguns fatos (como a expropriação histórica das terras indígenas; a legitimação da dominação e exploração dos índios em favor de um desenvolvimento que beneficia um número reduzidíssimo de pessoas; a destruição de uma cultura, considerada inferior, em nome de uma pretensa civilização superior; de ter-se cometido genocídio ao longo de nossa história, etc.), estar-se-ão criando as condições para que, através da ideologia dominante, muitas vezes científica e racionalmente justificada, se mascare toda uma realidade de exploração e dominação (Idem, p. 25).

Deixando de tratar a questão no âmbito ideológico e das considerações gerais produzidas e reproduzidas pela sociedade nacional, passar-se-á a algumas considerações relativas à construção que o conhecimento científico tem elaborado. Trata-se, evidentemente, de considerações introdutórias, destinadas a melhor adequar o campo problemático a que se propỏe este estudo, e que serão aprofundadas ao longo do traba- 
Iho.

As Ciências Hủmanas, a exemplo de outras ciências, têm procurado conhecer de forma adequada e profunda as muitas questões que afligem a sociedade, isto é: têm por objetivo tornar inteligível o real. (FREUND, 1973, p. 75)。 Porém,as abordagens científicas estão sujeitas a imperfeições, quer advenham da dificuldade em se caracterizar claramente o objeto de estudo, como, principalmente, das dificuldades inerentes a un campo do conhecimento que trabalha com variadas e diferentes concepções teóricas e metodológicas. Com relação ao primeiro aspecto, deve-se observar que as Ciências Humanas nasceram e se desenvolveram como um dos florescimentos intelectuais mais complicados das situações de existência das modernas sociedades industriais e de classes, sendo que seus pioneiros e fundadores se caracterizavam menos pelo exercício de atividades intelectuais socialmente diferenciadas, que pela participação mais ou menos ativa das grandes correntes de opinião dominantes na época, seja no terreno da reflexão, como no da propagação de idéias e da ação (FERNANDES, 1960, p. 273-279) . A este aspecto se une o fato das ciências humanas e históricas não serem o estudo de um conjunto de fatos exteriores aos homens, mas ao contrário, serem a análise de sua própria ação, de sua estrutura, das aspirações que a animam e das alterações que sofrem (GOIDMANN, 1980, p。27) .Quanto ao método, não há aquele que não acabe por perder sua fecundidade inicial, posto que todo método, assim como todo modelo teórico, é um produto histórico. Nesse sentido, não existe uma ciência capaz de postar-se diante do mundo livre de condicionamentos, de forma a-histórica (CASTRO e DIAS, 1974, p. 25-30)。Assim, o processo do conhecimento é ele próprio um fato humano, histórico e so- 
cial (GOIDMANN, 1980, p. 27), e por isso mesmo pode tanto mais compreender como deformar e mascarar a realidade (Iden, p. 70).

A problemática indígena, enquanto uma das questões que envolvem a sociedade brasileira, tem sido pensada prioritariamerte pela antropologia. Os estudos antropológicos dedicados a esta questão, durante muito tempo e ainda hoje, detiveram-se na descrição de gmipos indígenas considerados "primitivos", vistos de maneira isolada da problemática nacional e dando destaque aos aspectos curiosos e exóticos das "diferentes civilizações" (um tipo de contribuição etnográfica, portanto).

É razoavelmente grande a quantidade de estudos descritivos, de cunho predominantemente etnográfico, que têm sido produzidos. Evidentemente esses estudos trouxeram uma grande contribuição ao conhecimento das sociedades rumanas, notadamente quanto ao fornecimerto de vasto material empírico e que permite uma viءão panorâmica, embora fragmentária, da sociedade; mas, pouca foi a contribuição que deram para que se possa entender a totalidade do processo histórico do desenvolvimento recente da sociedade. No caso da problemática indígena, dada à fragmentação que esses estudos conduzem, fica difícil entende-la em sua inter-relação e dependência ao proces-so de desenvolvimento do capitalismo (LOMBARDI e NARAMURA, $1981, \mathrm{p} .10-11$ ).

Os pesquisadores que fugiram desse esquema descritivo ou acabaram por calcar seus estudos numa perspectiva culturalista, enfatizando a aculturação e o contato inter-étnico, ou acabaram caindo na esfera dos estudos sobre mudança sócio-cultural. De qualquer forma, couberam-lhes as tentativas 
de orientarem suas pesquisas partindo de pressupostos teóricos existentes nas ciências sociais $\epsilon$ buscando adaptá-los à realidade brasileira, contribuindo de algum modo xara a explicação da problemática indígena inserindo-a numa realidade mais ampla. Muitos dos estudos sobre o assunto afirmam que o enfrentamento ou a relação entre a etnia nacional em expansão e os diversos grupos tribais têm como efeito a extinção das tribos ou sua absorção gradativa pela sociedade nacional. Os conceitos utilizados para representar essa relação variam em conformidade com o referencial teórico e podem ser assim resumidos: miscigenação, aculturação, integração, contato cultural, ocidentalização, etc. De modo geral, a descrição da relação entre índios e brancos pretende abranger situações diferenciadas: nas áreas ainda não atingidas pela "civilização", encontraríamos tribos "virgens de contato", isto é, que não tiveram relações com não-índios; nas áreas ocupadas pela civilização, as tribos seriam tanto mais aculturadas, miscigenadas e integradas, quanto mais antiga fosse a ocupação, sendo que mitas já não se diferenciariam da população regional (Idem, r. IO-ll).

f fácil dar-se conta da precariedade de tais construçoes, pois, se fossem verdadeiras, seria praticamente impossível encontrar grupos indígenas nas áreas de longa ocupação nacional, como o Nordeste, Sudeste e Sul do Brasil.

A realidade dos fatos tem mostrado claramerte que o impacto da "civilização", embora desfigure a cultura tribal, não é suficiente para provocar a suposta "integração", inclusive prevista na legislação relativa aos índios e pregada como tarefa da FUNAI (Iei 6001, de 19 de dezembro de 1973)。 Via de regra, quando não ocorre a extinção, os índios conservam sua auto-identidade (ethos tribal), o que é suficiente pa- 
ra separá-los dos membros da sociedade nacional, conferindo- Ihes identidade própria. Issa questão de identidade assume importância crescente quarido se reconhece que os índios que atualmerte vivem no Estado de São Paulo, em situação de profunda desfigruração, não deixam de ser considerados índios e de ser identificados pelos demais segmentos componentes da sociedade nacional como tais:

"Mesmo frente a essas evidências, os índios em São Paulo não deixam de ser considerados índios e de ser identificados pelos 'outros' como tais, ainda que dentro de uma visão totalmente etnocêntrica. Assim, eles são caracterizados como índios tanto quando moram nas reservas, usufruem de uma terra e nela trabalham, como quando trabalham fora dela, recebem salário, têm um patrão e se relacionam com outros trabalhadores não-indígenas. Ou ainda quando caçam o que restou da fauna da Serra do Mar e vendem o artesanato que produzem, na Praça do Patriarca." (BOREILI e LUZ, 1984, p. 18)。

As autoras salientam que a terra, nesse contexto, aliada à recuperação e à preservação da memória e da cultura tribais, aparece como elemento fundamental para a permanência das comunidades indígenas no tempo (Idem, p. 19)。

Pelo que foi exposto, é necessário que se busque uma readequação na forma de se aboraar a problemática indígena, de tal modo que, ao mesmo tempo em que se capte a realidade tal como ela é, se possa explicar historicamente o proces-so de inserção do índio na sociedade nacional, oferecendo 
condições para que se analise sua práxis transformadora. Assim, crê-se que trabalhar a questão indígena exige um duplo esforço: por um lado, não se pode deixar de perceber que os índios se inserem historicamente no amplo prccesso de formação e desenvolvimento do modo de produção capitalista pelas características que este assume a nível da formação social brasileira. Tal como se entende a questão, essa -inserção não significa a destmição de sua identidade social, mas que são enquadradas enquanto uma categoria social determinada pela forma como produzem sua vida material, suas representações e suas relações com outros segmentos da sociedade brasileira, num determinado período histórico. Por outro lado, tem-se claro que essa inserção não significa simplesmente uma indiferenciação do Índio em relação aos demais segmentos sociais. Os Índios inserem-se enquanto uma forma de vida social que possui especificidades: definem-se e são identificados enquanto "Índios", o que os separa enquanto membros da sociedade nacional; possuem uma língua e um universo de representações que são próprios de sociedades autônomas; a concepção de propriedade e sua forma coletiva de apropriação, fato observado em todos os grupos tribais, constitui uma das contradições em relação ao conceito capitalista de propriedade (propriedade privada); a organização da produção e das relações de trabalho são conservadas, via de regra, de tal forma que permitam a apropriação coletiva dos frutos do trabalho (IOMBARDI, 1983, p. 26).

Convém aprofundar mais as questões acima para melhor contornar a problemática. A primeira questão a se observar é o processo de desenvolvimento do capitalismo, e o 
sistema colonial que desempenhou papel imprescindível para a acumulasão de capital:

"O sistema colonial fêz prosperar o comércio e a navegação. As sociedades dotadas de monopólio...eram poderosas alavancas de concentracão de capital. Ás colônias asseguravam mercado às manufaturas em expansão e, graças ao monopólio, numa acumulação acelerada。 As riquezas apresadas fora da Europa pela pilhagem, escraviza ̧̧̃̃o e massacre refluiam para a metrópole onde se transformavam em capital。" (MARX, Livro I, Vol。II, 1982, p。871).

Nesse quadro da colonização Européia em outras partes do mundo é que apareceu o primeiro quadro de inserção do índio, em que a expropriação de suas terras, o seu extermínio ou sua utilização como trabalho escravo eram fatores fundamentais da acumulação primitiva:

"A descoberta de ouro e prata na Ánérica, o extermínio das populações indígenas, forçadas a trabalhar no interior das minas, o início da conquista e pilhagem das Indias orientais e a transformação da Africa num vasto campo de caçada lucrativa são os acontecimentos que marcam os albores da era da produção capitalista. Esses processos idílicos são fatores fundamentais da acumulação primitiva。 (...)". (Idem, p. 868)。

Assim vista a questão, desde o início da expansão caritalista, scb a forma colonial, a problemática indígena deixou de comportar uma análise que coloque os índios de forma 
isolada ou separacia, zara projetá-la nun conjunto mais global representacio pela colônia, enquarto ua dos pilares do desenvol vimerto capitalista:

$$
\begin{aligned}
& \text { "... a exparsão colonialista es- } \\
& \text { vaziou as socieades não ocider- } \\
& \text { tais de seu conteúdo cultural, } \\
& \text { desmemou as etnias para proje- } \\
& \text { támas num conjunto mais global } \\
& \text { representados pela colônia." } \\
& \text { (CARviHo, I979, ․ I6). }
\end{aligned}
$$

Quario, porém, o capital se àeservolveu tornando-se a relação social acminante, rão significou a destruição de todas as formas àe orscanização de produção ou de relações de trabalho, que contiruaram a existir (MARC, 1983, p. 223)。E quando o capitalismo se encontra plenamente desenvolvido, ao seu lado encontram-se resquícios dos modos de produção precedente, conforme alerta KAUTSKY (1980, p. 25) e o próprio MARX (op. Cit, p. 223-224). A manutenção de relações de produção não-capitalista ter assim que ser entendida no seio do próprio processo histórico de āesenvolvimento do capitalismo: algumas relações de produção não-capitalista são reproduzidas para maior acumulação capitalista, já que se auto-reproduzem através da produção de 'subsistência e, em certos casos, acabam propiciando ao capital a apropriação de trabalho excedente, quando produzem uma mercadoria - quer como excedente de produção ou como prcảução especializaảa - cue ao entrar no mercado dominado pelo cajital possiibilitam a realização do trabalho incorporado à mercadoria, que o capitalista se apropria sob a forma de lucro; porém, o capital näo consegue destruir outras relações de produçäo, que acabaram por se constituir em entraves ao oleno desenvolvimento do capitalismo, como a existência de índios e posseiros, por exemplo (IOMBZRDI e MAYAMURA, I981, 
ps. $13-14)$.

Isto é explicado pela própria dinâmica do desenvolvimerto que não segue linearmente, mas de forma contraditória:

"Nias a transição da subordinação formal à subordinação real do trabalho ao capital não segue um desenvolvimento linear. o desenvolvimento do capitalismo em sua fase de transição - assim como do desenvolvimerto do capitalismo em geral - é o resultado de um conjunto de contradições." (SIIVA, 1980, p.22).

A tendência histórica, porém, é de que as relações pré-capitalistas não existiam de forma independente, senão enquanto relações subordinadas (SIIVA, 1980, p. 24)。Esta é a situação histórica dos indígenas no Brasil:

"... no Brasil, as comunidades definidas como indígenas, são levadas a participar de sistemas regionais e da economia regional através de um determinado conjun to de relações que as transformā em minoria sociológica e as coloca em situação de dependência." (CARVALHO, 1979, p。19).

Essa situação de subordinação ou de dependência não significa a conformação ou a manutenção da existência de sociedades autônomas, mas significa a submissão dessas sociedades à exploração de classe.

"O capitalismo, ao implari-
tar suas formas de produção,
elimina, gradativamente, outros
tipos de relações não capitalis-
tas. Entretanto, afirmar que o
sistema capitalista domina não


significa negar a existência de formas de relações não capitalistas de produção, que se assemelham às relações existentes em comunidades "primitivas", mas sim reter que as sociedades tribais, tomadas em seu conjunto, não estabelecem sua perspectiva histórica à margem do sistema de classes predominantes na sociedade global." (CARVALHO, 1979, p. 20).

Observe-se que o desenvolvimento do capitalismo é dinâmico e contraditório, o que implica reconhecer que é o próprio capital, no seio de seu movimerto histórico, que dá às outras relações sua categoria e sua importância, como observa - próprio MARX na Contribuição à Crítica da Economia Política: "(...) Em todas as formas de sociedade é uma prođựção determinada e as relações por ela produzidas que estabelecem a todas as outras produções e às relações que a elas dão origem a sua categoria e a sua importância. (...)" (MARX, 1983, p.224).

A questão da "categoria" e da "importância" dada pelo próprio capital às relações não capitalistas, tende a ser polêmica. Para alguns, a existência de relações pré-capitalistas sob a dominância do capitalismo não. pode ser explicada pela resistência. Veja-se um exemplo disso:

"(...) A presença das relações pré-capitalistas, a predominância dessas relações em certas regiões de uma formação social em que o modo de produção capitalista é o modo de produção dominante, não podem ser corretamente explicados por uma resistência dessas relações às rela- 
c̃oes capitalistas, porque a própria existência dessas relações é o resultado de uma forma determinada de dominação do capital." (SILVA, 1980, p. 23) ( o grifo é nosso).

No outro extremo está a consideração de que há resistência, que esta se expressa com um caráter anti-capitalista, sendo a expressão concreta das condições de classes impostas pelo capital. Esta posição é defendida, por exemplo, por MARTINS (1980) que considera a luta dos índios e posseiros como anticapitalista:

"O caráter anticapitalista da resistência no campo não deve ser depreciado e impugnado, sob pena de se cometer grave injustiça, derivada-basicamente de uma postura idealista. 0 anticapitalismo do lavrador é expressão concreta das suas condições de classe. Seria um absurdo exigir dele, senão em nome de uma postura totalitária, que pense como um operário de fábrica, que desenvolva uma concepção proletária da transformação da sociedade." (MARTINS, 1980, p. 19)。

$\mathrm{Na}$ opinião do autor, esse caráter anticapitalista, portanto, de resistência ao capital, fica claro em se tratando da luta pela terra:

"O próprio capital impôs,
no Brasil moderno, a luta pela
terra, como luta contra a pro-
priedade capitalista da terra.
ta terra de trabaliho contra a
terra de negócio. o que unifica
as aspiraçoses e lutas de um co-
lono kaúcho, de um posseiro ma-
ranhense e de um índio Tapira pé


é essa resistência obstinada contra a expansão da expropriação capitalista da terra. Mesmo que cada categoria social, construa o seu próprio refime de propriedade anticapitalista: a propriedade camponesa, a propriedade comunitária e a posse." (Idem, p。6I-62)。

Admirando a questão ristoricamente, é possível que se distingam três processos através dos quais as relações de produção não capitalistas acabam se inserindo no capitalismo: a absorção e ou destruição, a subordinação e resistência. No primeiro caso, a expansão capitalista tende a incorporar, ou integrar, ou absorver em seu seio as relações de produção não-capitalistas. A subordinação se dá quando o capital não destrói as bases de existêrcia das relações não-capitalistas, mas as submete direta ou indiretamente às condições de reprodução capitalistas, mormente através do mercado e do comércio, no qual o capital acaba se apropriando do trabalho excedente incorporado à mercadoria. Finalmente, existem relações de produção que o capital não consegue eliminar ou submeter e que, ao resistirem a sua penetração, geram um tipo de contradição que tende a negar a totalidade do processo de produção capitalista.

Esses processos não são, porém, estanques. Assim, tem-se que reconhecer que a resistência à penetração do capital, ou o anticapitalismo de determinadas categorias sociais - como o índio, por exemplo-, indicada pelas lutas contra a expropriação das terras e/ou contra a proletarização, não indica a constituição de um ou mais modos de produção que coexistam sob a dominância do capitalismo. Não se pode esque- 
cer que o capital não atua setorizado, mas no conjunto da estrutura econômica, apoiado pelas instâncias jurídico-políticas e ideológicas: se o capital não consegue apropriar-se dos meios de produção ou do trabalho, acaba dominando através do mercado capitalista, o que é suficiente para reforçar as condições de controle e submissão dessas relações de produção não capitalistas, bem como de suas respectivas categorias sociais, aos interesses maiores do capital (sua própria reprodução ampliada). É assim que o capital não só domina essas relações de produção, como acaba enquadrando eミtas categorias sociais na estrutura social da sociedade capitalista.

Com relação ao índio, que é a problemática em evidência, essa questão fica claramente caracterizada:

"Através do mercado e do comércio se estabelecem os nexos econômicos determinantes da participação indígena na sociedade nacional... A produção indígena, mesmo residual, é inseparável da produção regional (e global) e, nesse sentido, as relações de classe, que se produzem no interior das relações inter-étnicas, tornam-se o referencial básico para a análise da mudança. As etnias passam a se definir através de uma série de atributos culturais loealizados numa escala hierárquica onde os índios se situam no escalão mais inferior." (CARVALHO, 1979, p. 121)。

Nessa perspectiva, a história do índio brasileiro aparece como uma das faces da história. da expansão capitalista. Nessa expansão, o capitalismo vai invadindo o mundo dos índios, valendo-se de diversificadas armas: quer através do choque direto de extermínio, quer por outras formas mais len- 
tas, como a infiltração de novos valores, como meio de amortecer os choques violentos entre as etnias envolvidas. Da carte dos índios, sua luta tem sido contra a invasão de seus territórios e contra a destruição de seu modo de organizar para produzir e reproduzir os meios necessários à sua vida material, bem como de sua vi são de mundo e organização.

Ao longo desse processo histórico, diverzas "nações" indígena: foram dizimadas, expulsas de seu habitat e a Erande maioria sofreu intervenção direta ou indireta de aigências representativas dos interesses dominantes para que se desfigurasse. Porém, acuados a cada investida da expansão capitalista e em contato com a "civilização", os índios têm-se adequado a cada realidade histórica, criando novas formas de defesa, reproduzindo sob "novas vestes" seu modo de ser, pensar e agir. En outras palavras, mesmo com toda a pressão que têm sofrido continuadamente pelo capital para que se subordinem às condições de sua reprodução, os diferentes grupos tribais têm produzido e reproduzido as condições para continuar a ser índio, mantendo assim a sua identidade com já se disse. A questão fci adequadamente colocada na seguinte forma:

"...a luta pela reconstrução da identidade não im lica no retorno - historicamente inviável - à vida tribal.

Implica, sim, na síntese dos vários elementos que compõem os universos contraditórios e conflitantes do mundo tribal e do mundo capitalista, síntese es ta que deve ser buscada pela valorização da diferença: o 'eu' deve se sentir diferente do 'ou- 
tro' e se afirmar como tal." (BORELII E LUZ, 1984, D. 19)。

E nesse quadro referencial de problemática que se coloca a proposta de estudar as condições históricas de inserção dos índios Xavante no processo de desenvolvimento histórico do capitalismo no Brasil, principalmente o processo de ocupação do centro-oeste, na tentativa de analisar o papel que as instituições protecionistas, enauanto aparelhos a serviço dos interesses dominantes, desempenharam.

A complexidade do problema exige que se faça a distinção de três ordens de questões: a primeira se refere ao desenvolvimento do capitalismo no Brasil; a segunda, à política e à prática indigenista, engendrada em conformidade com os interesses dominantes do capital; e a última, ao processo histórico por que passaram os Xavante.

Sem a menor pretensão de se entrar no amplo debate sobre a economia política brasileira( ${ }^{(1)}$ e dada a existência de diferentes modelos teórico-metodológicos que buscam ana lisar e interpretar o desenvolvimento econômico brasileiro, é preciso que se tenha uma compreensão básica do desenvolvimento do capitalismo no Brasil e das relações existentes entre o capitalismo enquanto modo de produção e as condições particulares de sua realização a nível da formação e desenvolvimento nacional brasileiro. Em se entendendo que o desenvolvimento histórico do capitalismo é, em sua essência, contraditório,

(1) - Entre outros trabalhos, é de se destacar que a problemática da economia política brasileira foi objeto de estudo de recente tese de doutoramento, cujo título é A Economia Política Brasileira, de Guido IMANTEGA (1984)。 
isto é, transforma-se historicamente por força das negações que carrega em seu próprio seio, é preciso que se entendam, também, os mecanismos que utiliza para subordinar todas as formas que impedem ou bloqueiam sua reprodução ampliada, bem como a manifestação da resistência ao capital.

No interesse da problemática do indigenismo no Brasil, apresenta-se outro nível do problema: a política e a prática indigenista engendrada historicamente. Nesse quadro, o indigenismo aparece enquanto um conjunto de práticas, de normas e de ações que foram adotadas pelo governo ou pelos agentes envolvidos direta ou indiretamente com os índios。 Assim entendido o indigenismo, outro aspecto que exige compreensão é quanto aos mecanismos através dos quais se operava uma intervenção deliberada sobre as comunidades tribais, objetivando disciplinar as relações e os comportamentos desses grupos, em conformidade com os interesses e valores dominantes. A política indigenista tende, assim, a assumir historicamente duplo papel: por um lado, é o aparelho que instrumetaliza, no plano jurídico-formal, ideológico e da ação prática e concreta, os interesses dominantes da expansão capitalista; por outro lado, é o espaço que viabiliza e/ou reflete as relações envolvendo os índios e os representantes da sociedade nacional, acabando por dar corpo à contradição entre o movimento de subordinação de todas as sociedades, relações de produção e/ou segmentos sociais que impedem a plena realização do capital, e entre a resistência à penetração, domínio e/ou controle do capital pelas mesmas.

Dada a amplitude histórica e geográfica da problemática, tornando inviável uma análise profunda da questão indígena, e para não cair no equívoco de tomar os índios en- 
quanto categoria genérica, tomar-se-á para estudo os írdios Xavante ${ }^{(2)}$. Em relação aos Xavante, importa saber: como o desenvolvimento do capitalismo afetou o grupo tribal; como se deu a intervenção indigenista em relação a eles; e qual a manifestação desses índios face à penetração e desenvolvimento do capitalismo, quer em termos de subordinação aos interesses do capital, quanto à resistência que interpuseram historicamente. Ao tomar os Xavante como objeto de estudo não se tem a. menor intenção de gereralizações, mas de estudar como as condições dominantes, impostas pelo desenvolvimento do capitalismo e instrumentalizadas no indigenismo, determinaram as possibilidades históricas da práxis desse grupo indígena em termos de sua subordinação ou resistência ao capital.

Pelas informações que se têm depositadas na literatura que trata direta ou indiretamente dos índios ao Iongo da história do Brasil, os problemas advindos das relações en-

(2) - Existiram três grupos indígenas denominados genericamente de Xavante: os OFAIE-Xavante, os OTI-Xavante e os AUWẼ-Xavante. Os três são caracterizados pela especialização na vida campestre e viviam em regiões de cerrado, sendo que os elementos que os distinguem é a localização do habitat e a denominação específica. Os AFAI Ĺ localizavam-se na região sul de Caiapônia, Goiás, nas terras banhadas pelos afluentes do rio Paraná; os OTI, residiam nas terras situadas também no vale do rio Paraná, mas em território paulista; os AUW̃̃, originalmente habitavam o norte de Goiás, nos vales do Tocantins, migrando a partir das décadas iniciais do século XIX em direção ao rio Araguaia, até instalaram-se, em meados do século passado, na região da Serra do Roncador e rio das Mortes, na zona norte-oriental do Planalto Central do Brasil, em terras matogrossenses. É este terceiro grupo, os AUW -XAVANTE, que constitui nosso objeto particular de estudo. 
tre índios e brancos (não entendidas enquanto categorias étnicas, mas sim em seu sentido amplo de diferentes formações sociais) datam desde o descobrimento, passando por toda a história do Brasil.

Com relação às informações que se têm sobre os Xavante, essas só passam a ser documentadas a partir de 1762 quando se tem uma das primeiras notícias sobre essa tribo (RAVAGNAiNI, 1978, p. 14). Porém, como essa tribo pertence ao grupo Jê que ocupa todo o planalto brasileiro (ver NIMUENDAJU, 1981), isto desde a época do descobrimento, não fica difícil dar-se conta de que sofreu profundamente todos os resultados do desenvolvimento do capitalismo nacional, quer quanto à expropriação do território tribal, ou das expedições de resgate ou, finalmente, do extermínio de sua população.

Isto fica ainda mais patente se for levado em conta que desde o final do século XVI o centro do país foi percorrido por inúmeras entradas e bandeiras (RAVAGNANI, 1978, p. 1-9), donde se pode concluir ter "...poucas ou talvez nenhuma tribo permanecido imune às suas investidas. (...)" (RAVAGNANI, 1978, p. 13). Ainda mais, tendo-se em vista sua localização geográfica na época (até início do século XIX), isto é, toda a bacia do Tocantins, desde o sul de Goiás até o Maranhão, estendendo-se do rio São Francisco até o Araguaia (GIACCARIA e HEIDE, 1972, p. 14), pode-se ter a certeza de que muitos foram os conflitos que os índios tiveram com as frentes de expansão econômica nacional.

Na base específica da elaboração escrita sobre os Xavante, existem muitas informações esparsas ou artigos, 
que se caracterizam como relatos de viagens ou trabalhos jornalísticos. No âmbito da elaboração científica propriamente dita, foram estudados por MAYBURY-IEWIS (1967), por GIACCARIA e HEIDE (1972, 1975a e 1975b), por MULIER (1976), RAVAGNANI (1978) e SILVA (1980).

David MAYBURY-IEWIS (1967), é considerado o primeiro a fazer um estudo etnográfico profundo sobre a sociedade Xavante, contando com um modelo explicativo que the possibilitou ressaltar as relações e os princípios organizacionais do sistema social e do pensamento Xavante. Seu modelo teórico situa-se no quadro mais amplo-das preocupações do "HarvardCentral Brazil Research Project", que se ocupou da análise das sociedades Jê em geral, retomando, através delas, as discussões sobre as organizações duais e as alternativas metodológicas a sua análise (SILVA, 1980, p. 26). Akwẽ-Shavante Society é sua obra básica, constituindo-se numa monografia no sentido clássico da Escola Britânica (Idem, p. 28). Apresenta um modelo explicativo da sociedade Xavante como um todo, isto é: como um sitema, a partir do estudo detalhado de seus sub-sistemas. Preocupa-se fundamentalmente com as linhas de segmentação responsáveis pela formação dos vários grupos sociais, principalmente linhagens patrilineares e grupos de idade. Conforme bem observa Niaria Aracy P.I.SIIVA (1980, p。28-29), as relações interpessoais não foram tratadas de modo particular, a não ser aquelas que se deram dentro dos limites de um mesmo grupo social.

- livro dos missionários salesianos Bartolomeu GIACCARIA e Adalberto HEIDE, XAVANTE (Auwẽ Uptabi: Povo Autên- 
tico), de 1972, é extremamente ricc em informações e descrições etnográficas e oferece, além aisso, dados linguísticos muito importantes, frutos de um lorigo e intenso convívio de seus autores com os Xavante. Embora a obra como um todo apreenda quase que exclusivamente a forma tradicional da organização, da estrutura e das funções na sociedade Xavante, assim como suas representações, ao tratar dos "dados históricos" (GIACCARIA e HEIDE, 1972, p. 13-33) recupera o período imediatamente posterior ao da pacificação promovida pelo S.P.I. (Serviço de Proteção aos fndios) e que revela a continuidade das expedições punitivas, dos massacres, das transferências de território e das epidemias que reduziram parte do contingente populacional Xavante. Porém, é uma obra essencialmente etrográfica que se ressente na falta de uma orientação metodológica definida, de modo que o conhecimerto dos autores não é passado direta e facilmente aos leitores. As tentativas de interpretação são deficientes, sendo o emprego dos termos próprios da teoria antropológica nem sempre apropriados (SILVA, 1980, p. 28).

Alguns anos mais tarde (1975), esses missionários voltam a publicar outros dois importantes trabalhos: Jerônimo Xavante Conta (1975a) e Jerônimo Xavante Sonha (1975b)。 Nestas duas obras, os autores publicam tudo o que Jerônimo, o Xavante mais idoso atualmente e que é Wamarĩ Tedewa (sonhador, pacificador) entre os seus, conta aos rapazes nas longas reuniões que os velhos realizam com os jovens para thes transmitir sua história, suas leis, costumes, festas e instruí-los sobre a vida (cf.1975a, p.9). Revelar que para os Yavante mitos, lendas, contos e sonhos não são distintos: "Tudo é 
real; a única distinção é relacionada ao tempo. Antigamente, isto é, no tempo dos avós; e recentes, isto é, 'vividos' pelo próprio narrador." (Idem, p.10). Tudo o que está narrado é fruto de longas gravações que os membros mais novos da tribo escutaram e que um deles gravou. Os autores evitaram estar presentes para "não inibir o narrador e para que não fossen alteradas a originalidade e autencidade dos contoso" (Idem, p. 10). O que essas duas obras significam foi adequadamente captado por Egon SCHADEN: "...textos que exprimem e documentam a visão do mundo e a concepção da vida tal como as desenvolveram os antepassados da tribo, embora nessas narrativas já apareça também a figura do homem civilizado como problema que desafia a imaginação mística. (...)" (SCHADEN, "Apresentação", in GIACCARIA e HEIDE, 1975a, p. 7-8)。

A Pintura do Corro e os Ornamentos Xavante: arte Visual e Comunicação é a dissertação de mestrado de Regina Aparecida Polo NuLLER, apresentada à Universidade Estadual de Campinas, em 1976. O objetivo geral do trabalho é de "... demonstrar que a arte como qualquer sistema de linguagem é usada pelos homens para ordenar e classificar a realidade, como processo cognitivo básico de apreensão de seu universo." (MULIER, 1976, "Introdução", s/p.). Quanto à metodologia, a autora busca trazer uma contribuição ao referencial utilizado pela antropologia ao "aplicar um modelo lingtústico ao material etnográfico para demonstrar que a ornamentação corporal Xavante é um sistema de comunicação visual com estrutura própria como qualquer outro sistema de linguagem..." (Idem, 1976, p。206).

De mocio geral, a pesoutisa de Regina NuLLER com- 
plementa sobremaneira os dados etnográficos dos padrões tradicionais dos Xavante, avançando na dimensão que a forma e sua significação têm em relação à estrutura social global. Não somente avança em relação aos trabalhos de IMAYBURY-IEWIS e de GIACCARIA e HEIDE na exposição etnográfica tradicional, como revela uma dimensão da vida social, até ainda inexplorada. Secundariamente, em relação aos objetivos de sua pesquisa, fornece, em alguns momentos, importantes observações de mudanças que estão ocorrendo nesses padrões tradicionais advindas do contato com a sociedade envolvente, e que são importantes para os objetivos deste trabalho.

A Experiência Xavante com o Mrundo dos Brancos é - título da Tese de Doutoramento de Oswaldo Miartins RAVAGNANI apresentaāa à Escola Pós-Graduada de Ciências Sociais da Fundação Escola de Sociologia e Política de São Paulo, em 1978. Trata-se de um exaustivo trabalho de reconstrução histórica, solidamente baseado num levantamento das informações sobre os Xavante, espalhadas em livros, revistas e documentos oficiais, buscando concatená-las para se ter uma idéia do passado histórico do grupo e analisá-lo de forma a entender o seu comportamento (RAVAGNAIII, 1978, p.XII). o objetivo do autor foi de "... reconstruir a história dos índios Xavante a partir de seu contato com segmentos da sociedade nacional, ainda no século XVIII, até sua submissão no final da primeira metade do séculc XX (...)" (Idem, p. IX). Para atingir esse objetivo, o autor analisou as frentes de expansão com as quais os Xavante entraram em contato, quer seja em Goiás, onde estiveram por um certo tempo, ou já em terras matogrossenses, último refúgio e no qual foram submetidos. Em termos das frentes de expansão con- 
siderov. "... o interesse econômico que as impr.lsionava, as condições em que se deram, o apoio oficial que receberam, stia agressividade para desalojar os índios de suas terras, e so-

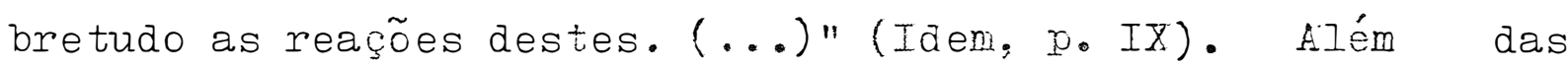
frentes de expansão, a pesquisa aborda o tipo de contato que tiveram com as bandeiras, inclusive as posteriores a 1930, com os missionários e com o S.P.I. (Serviço de Proteção aos Indios), analisando os "métodos utilizados, os interesses que os moviam a este fim, a atuação que tiveram e acima de tudo a reação dos iná́genas e os resultados obtidos. (...)" (Idem, p. $\mathrm{X})$.

É desnecessário enfatizar a importância do trabalho de RAVAGNANI, principalmente em relação à grande quantidade de informações que dá a conhecer sobre as frentes de expansão no centro-oeste brasileiro e o contato que tiveram com os Xavante. Porém, dada à falta de explicitação do referencial teórico e metodológico com que pauta suas análises, estas acabam por fragmentar a totalidade representada por um momento histórico. Dessa forma, o que aparece são "fatos", "dados" que têm um limite de análise muito estreito. Assim, quando trata das frentes de expansão que atingiram Goiás desde o século XVI, representadas pelo aprisionamento de índios e busca de metais e pedras preciosas, depois pela atividade mineira, etc., esse movimento é tratado em si mesmo, como se nenhuma relação tivesse com os mecanismos básicos que pautavam a economia brasileira, ou, a nível ainda mais amplo, com os processos através dos quais se dava a "acumulação primitiva de capital".

Ao entrar no reríodo mais recente, quando os Xa- 
vante já estão ocupando um território tribal em terras matogrossenses, perde de vista o processo econômico mais recente, representado por novas condições de desenvolvimento do capitalismo, inicialmente sob a dominância do capital mercantil sob - Estado Nacional e, depois, scb o controle do capital industrial. As condições em que se efetivam os contatos entre os índios e as frentes de expansão, somente superficialmente são relacionadas ao desenvolvimentc econômico, ficando o leitor à espera de melhores explicações para as tentativas de pacificação realizadas por missionários e setores das frentes da expansão. o mesmo ocorre em relação ao empenho do Governo Federal, através do S.P.I., em realizar a curto prazo a pacificação do grupo. Ainda que o autor consiga, na maioria dos casos, chegar a conclusões corretas (como a de que a pacificação representou a abertura das terras Xavante às empresas agro-pecuárias - Idem, p. 188), carece o texto escrito de uma recuperação do processo histórico em que se dão e das condições geradoras de determinadas situações.

A última elaboração sistemática sobre os Xavante, de que se tem conhecimento, é a Tese de Doutoramento de Maria Aracy de Padua Iopes da SIIVA, apresentada à Universidade de São Paulo, em 1980, e que levou o título: NOMES E AMLGOS: da prática Xavante a uma reflexão sobre os Jê。 A autora propõe-se a "apresentar a etnografia do sistema de nominação Xavante e da relação entre indivíduos que se denominam mutuamerte $\underline{\tilde{i} \text {-amõ }}$ (Iiteralmente, "meu outro"), completando o que se conhece sobre a organização social dos Xavante com dados referentes a uma esfera de relações sociais pouco estudadas até agora entre eles. São relações interpessoais formalizadas e 
que recebem expressão ritual "... são relações cerimoniais que ligam indivíduos que se classificam mutuamente como "outros" ..." (SIIVA, 1980, p. 29). Vista a questão em relação ao que já se escreveu sobre oミ Xavante, bem como sobre os Jê, seu objetivo foi "discutir a validade de uso e a capacidade explicativa de certos conceitos e de modelos previamente elaborados a respeito da sociedade Xavante... e optou por fazê-los através da apresentação de dados etnográficos inéditos relativos aos nomes pessoais e aos amigos formais entre os Xavante." (Idem, p. 228-229).

Tomando a elaboração etnográfica sobre os Xavante, fica evidente que a autora avançou na elucidação das características tradicionais do grupo, tomando como objeto de estudo uma esfera da vida social ainda não estudada. Além disso, - trabalho é rico na coleta sistemática de importantes dados etnográficos, o que permitiu à pesquisadora questionar algumas explicações relativas à estrutura social deste grupo anteriormente elaboradas.

Uma preocupação de SIIVA que merece realce é quanto ao seu posicionamento em relação aos modelos. teóricos existentes na etnologia contemporânea. Para a autorá, o estudo dos grupos Jê, juntamente com o de outras sociedades indígenas brasileiras, tem sido alvo de pesquisas sistemáticas "... dada a possibilidade que oferecem à etnologia contemporânea de repensar os modelos analíticos clássicos, construídos a partir da etnografia melanésia, polinésia e africana. (...)" ( Idem, p. 3I). Na medida èm que os modelos analíticos clássicos não conseø̃uem dar conta das peculiaridades das sociedades sul-americanas, surge a necessidade "... de elaboração de novos conceitos e de uma nova linguagem aptos a fazê-los." 
(Idem, p. 3I).

Neste sentido, estabelecem-se os limites da aná lise feita por ViAYBURY-LEWIS (1967): por um lado, seu modelo analítico deixa evidente a influência dos modelos africanistas; por outro lado, sua análise propunha novos caminhos que procuravam dar conta da dinâmica própria de uma sociedade Jê. Porém, na medida em que possibilitava "... Uma compreensão muito satisfatória da organização social e do pensamento dos Xavante, o autor chegou a alguns "becos sem saídas" justamente no tocante à determinação exata das linhagens quanto à sua filiação clãnica e à determinação dos critérios de maturidade masculina e feminina..." (Idem, p. 33).

O trabalho procura superar muitos dos limites existentes nos modelos explicativos da etnologia, ainda que sua contribuição se prenda a modelos teóricos que, em termos metodológicos, ainda estão pautados nas clássicas elaborações antropológicas.

Secundariamente ao corpo principal do trabalho, a autora traz interessantes informações sobre algumas das transformações que pôde observar entre os Xavante, tomando como base os padrões tradicionais do grupo. Além dos dados relativos aos aldeamentos e às Reservas Indígrinas, retrata de forma sumária e genérica a atual situação desses índios com relação a algumas esferas da vida social tribal, mudadas em face do contato: economia, política e "outros aspectos" (estrutura familiar, atividade ritual, acréscimos e perdas na vida ritual). Ademais, salienta a resistência dos Xavante ao impacto do contato com a sociedade capitalista (Idem, p. 3-22).

Após ressaltar as linhas gerais da produção 
cientifica sobre o grupo tribal em questão é possível uma definição mais adequada dos objetivos desta pesquisa, que tem por objetivo amplo: estudar as condições históricas de inserção dos índios Xavante no processo de desenvolvimento do capitalismo no Brasil, analisando o papel que as instituições protecionistas desempenharam enquanto "intermediárias" a serviço dos interesses dominantes.

Este objetivo geral, pode ser desmembrado em quatro objetivos específicos que ajudam a operacionalisar a redação: I) caracterizar as condições de formação e desenvolvimento do capitalismo no Brasil; 2) estudar as formas históricas que a política indigenista foi assumindo, buscando estabelecer suas relações com o desenvolvimento econômico nacional; 3) analisar as condições históricas do contato entre os índios Xavante e a sociedade nacional, bem como o papel desempenhado pelos setores ou segmentos encarregados de aplicar a política indigenista ao longo desse processo; 4) explicar as conseqtências sofridas pela sociedade Xavante, como fruto do contato com a sociedade nacional, buscando entiender a sua luta histórica em termos de subordinação ou resistência em relação a uma sociedade capitalista como o é a brasileira.

A problemática e os objetivos propostos serão tratados no período mercantil-escravista nacional fazendo-se assim un corte que permita analisar de forma mais profunda as diversas questões em termos históricos. 
3. A QUESTÃO INDAGENA E O DESETVCLVINENTO DO CAPITALISMO NO BRASIL COLONIAL

o presente capítulo, dividido em três partes, introduz o estudo da questäo indígena e do desenvolvimento do capitalismo no Brasil, sintetizando os principais aspectos do período colonial de nosso relatório de pesquisa (IOMBARDI, 1985, p. 33 a 163). Nesse período os Xavante viviam na região centro-oeste do território brasileiro e sofriam as conseqtências da ocüpação, econômica colonial, motivada pela exploração agrícola, pecuária e mineira, cristalizadas numa política e numa prática indigenista que vendc no índio um empecilho ac desenvolvimento e ocupação das terras, voltava-se para o extermínio daqueles grupos que dificultavam a colonização e/ou para a "desinfecção" das terras consideradas necescárias à o cupação pela "civilização".

3.1. A Formação Ėconômica Brasileira: a Economia Colonial

A formação da economia colonial moderna fez parte 
do amplo processo de "constituição do Modo de Produção Capitalista..." (NELLO, 1975, p. 28), quando se criavam as condições para superação do modo de produção feudaI e concomitantemente de desenvolvimento do capitalismo (Ver LAPA, 1981, p. 66-67).

Portanto, o que o sistema colonial fez foi viabilizar a transformạão do capital em capital industrial. Esta transformą̧ão não se deu repentinamente, mas no lento processo em que ocorreu, o capital mercantil se desenvolve, ao mesmo tempo em que quebravam as resistencias das estruturas pré-capitalistas (IAPA, 1982, p. 12-13). Para que ocorresse a superação do Modo de Produção Feudal e a constituịão do Modo de Produção Capitalista, necessitava-se, portanto, de mecanismos que propiciassem a acumulacão de capital. É este o sentido da expansão marítima, dos descobrimentos e das colonizações: aparecem como um desdobramento da expansão comercial levada a cabo pelos países da Europa Ocidental(3).

Contudo, essa atividade comercial e essa colonização, assumiram uma nova forma para que pudessem cumprir seu papel na acumulação: é a forna mercantilista (4) 。 mercantilismo se estruturou sobre três pilares: seu ponto de partida foi a idéia metalista, isto é, a riqueza de cada nação era identificada com o montante de metais nobres e pedras preciosas; para se conseguir acumular esta riqueza, o receituário mercantilista recomendava a formação de uma doutrina ou política de balança de comércio favorável, isto é, exportar em quantiaade maior que o montante de importações, de tal modo

\footnotetext{
(3) Sobre o assunto, para maior profundidade, ver: PRAD JR., 1979, p. 21-22; NOVAIS, 1981, p. 66-68; NIELIO; 1975, p. 28-30, entre outros.
}

(4) Sobre o mercantilismo, ver DOBB (198I, p. 181 e s.)。 
que se obtivesse um saldo favorável na transạ̃a o comercial; esta, por sua ver: propugnava por uma política protecionista, ou de fomento da produção nacional, estímulo às exportações de manufatura, dificuldade ou mesmo proibição da importação de produtos manufaturados, defesa da saída de matérias-primas e estímulo ài importação de produtos primários (NOVAIś, 1981, p. $58-61)$

Para que a colonização moderna fizesse sentido, neste quadro de comércio internacional, como evidenciou PRADO JR. (1979, p. 19-32), teria que ter uma natureza essencialmente comercial: quer explorando os recursos naturais pela coleta, em proveito do comércio europeu, quer produzindo para o mercado europeu os produtos "tropicais"; ou explorando metais" nobres e pedras preciosas para a riqueza das metrópoles européias.

E, pois, neste contexto de capitalismo mercantil que se pode inferir o significado e a importância das colônias - retaguarda econômica da metrópole (NOVAIS, 1981, p. 61-62).

Enquanto a burguesia ascendente não possuía uma capacidade de acumulação endógena, isto é, no interior da própria estrutura econômica capitalista, necessitava de meios externos que propiciassem a acumulação, que por ser anterior à acumulação capitalistà propriamente dita, foi denominada de primitiva por Marx ${ }^{(5)}$. Disto decorre que a função da colonização era a de ser um dos instrumentos para a acumulação primi-

(5) Marx assim se referiu ao processo de acumulação primitiva de capital: "... uma acumulação primitiva, anterior à acumulação capitalista, uma acumulação que não decorre do modo capitalista de produção, mas é seu ponto de partida." (MARX, 1982, Iivro I, Vol。II, p。 828). 
tiva de capital ${ }^{(6)}$.

Desde cedo, porém, a expansão ultramarina desdobra-se em concorrência colonial entre os Estados envolvidos nesse processo que se instaura no seio do capitalismo mercantil (7). Para fazer face à concorrência inter-metropolitana e possibilitar um estímulo à acumulação primitiva de capital, fez-se necessária a criação de mecanismos capazes de ajustar a expansão colonizadora acs mecanismos da economia européia: por um lado, enquanto economia produtora que propiciasse a apropriação do Iucros gerados na colônia pela burguesia metropolitana; por outro lado, enquanto mercado para a produção da metrópole (NELLO, 1975, p. 29)。O mecanismo por excelência que promoveu este ajustamento foi o monopćlio comercial ou "exclusivo" metropolitano $^{(8)}$.

É evidente que este processo em análise não se desenvolveu de forma linear e mecânica. Mesmo reconhecendo a dominação exercida pelo comércio exterior e pela prcdução colonial, existiram contradições profundas que marcaram o comércio internacional sob o exclusivo metropolitano.

(6) A acumulação primitiva de capital aparece em Marx como um vasto processo histórico em que se distinguem três mecanismos básicos: 1) a pilhagem colonial e a acumulação mercantil; 2) a política dos estados mercantilistas, e 3) a expropriação dos trabalhadores dos seus meios de produção. Aponta que a abertura do comércio mundial foi crucial para - processo de acumulação primitiva (MARX, idem, ibidem, p. 828-882).

(7) Sôbre a concorrência colonial entre os Estados europeus, ver FURTADO (1982, p. 10-15 e 19-31) e NOVAIS (1981, p。 $72-90)$.

(8) Para se aprofundar a questão do "exclusivo" metropolitano, ver NIELLO ( 1975, p. 31 e s.) e NOVAIS ( 1981, p. 88 e s.). 
A nível do exclusivo metropolitano, os tratados comerciais entre as metrópoles (através dos quais se concediam vantagens comerciais no ultramar a outras potências), as licenças concedidas a mercadores estrangeiros para comerciarem diretamente nos mercados coloniais e c contrabando e a pirataria, tornam manifesto que o exclusivo metropolitano se constituía nüm paradoxo à economia mercantil capitalista (NOVAIS, I981, p. 90 e s.). Ainda, embora a econcmia colonial fosse dominada pelo comércio metrópole-colônia-metrópole, é fundamental que se considere também as relaçoes comerciais que se travavam entre as diferentes metrópoles, entre as colônias de uma mesma metrópole e até entre as colônias de diferentes metrópoles. Este comércio inter-colonial tem sido considerado como um comércio periférico no interior do próprio pacto colonial, porém, como assinala José Roberto do Amaral IAPA (1982, p. 66-72), este se realizava com uma frequência e regularidade que Ihe tira o caráter circunstancial, abalando os próprios fundamentos do exclusivo metropolitano.

Ademais, se há evidência da contradição demonstrada pelas nações hegemônicas, através de estratégias, mecanismos e movimentos, bem como pela reiteração e preservação das práticas coloniais, internamente nas próprias colônias se manifestam oposições, através das quais procuravam suavizar, redirecionar ou mesmo romper com as malhas do sistema colonial: são as inconfidências, as rebeliões e as resistências. A repressão que sobre elas se abate dá clara visão dos problemas e contradições que o sistema thes coloca ao longo destes três séculos em que perdura o regime colonial (LAPA, I982, p. 9-10). De modo geral, a montagem da colonização moderna, em conformidade ccm os mecanismos do capitalismo mercantil se 
fez promovendo, inicialmente, o povoamento, com produção para - consumo local; em seguida, entrosando-se nas linhas do comércio europeu (NOVAIs, 1981, p. 92 e s.).

Quando entrosada nas linhas do comércio europeu, cumprindo a função a que se destinou, é que foi organizada a produção. Na agricultura, a produção se organiza apoiada sobre três elementos fundamentais: grande propriedade, monocultura, mão-de-obra cativa. Na mineração se adotará uma organização idêntica à da agricultura, afora as distinções e especificidades de natureza técnica: é ainda a exploração em larga escala, onde predominam grandes unidades produtoras, apoiada sobre o trabalho escravo. Outra atividade fundamental foi a extrativa. Essa atividade organiza-se de forma diferente - não tinha por base a propriedade territorial, não era uma atividade permanente e havia relativa liberdade no trabalho de coleta; porém, estruturalmente, em nada se diferenciará das demais atividades da colônia. Além destas atividades fundamentais, existiam outras (como a pecuária, a criação, a produção alimentar) que não tinham por objetivo produzir para o comércio externo, mas subsidiar, amparar e tornar possível a produção exportadora (PRADO JR., 1979, p. 119-125).

Deste modo, é a inserção do sistema colonial no processo global de formạ̃ão do capitalismo, que permite compreender adequadamente a economia colonial, como constituida pela interação entre dois setores básicos: um, exportador, e, outro, produtor de alimentos. Ao setor exportador cabia produzir, em escala mercantil, os produtos coloniais que possuiam procura no mercado mundial: açúcar, tabaco, algodão, cacau, anil, matériais-primas, metais nobres e pedras preciosas, etc. Tal produção mercantil era organizada pelos proprietários dos 
meios de produção e assentava-se no trabalho compulsório, servil ou escravo (NOVAIS, 1981, p。92-96). O setor produtor de alimentos surgia como um setor embutido no setor exportador, organizado de forma a que parte do tempo da força de trabalho emrregada pelo setor exportador fosse utilizada na produção de sua própria subsistência (NiELIO, 1975, p。26-27). Desta forma, enquanto o setor exportador era caracteristicamente mercartil, - setor produtor de alimentos funcionava como seu suporte, não sendo em si propriamente mercantil (PRADO JR., 1979, p. 157 e s.).

Ainda no caso da produção de alimertus, foram os mecanismos do sistema colonial que definiram o conjunto e imprimiram o ritmo da produção. Assim, quando o setor exportador estava em pleno funcionamento e a procura externa ampliava-se, as unidades produtivas tendiam a mobilizar todos os recursos na produção exportadora; quando, ao contrário, a procu ra externa se retraía, as unidades produtivas tendiam a colocar fatores para a produção de subsistência, garantindo endogenamente a reprodução da população colonial e, em certo sentido, do capital. Portanto, a produção de alimentos acaba con $\underline{\underline{S}}$ tituindo-se num setor que se revela embutido no setor exportador e, ao mesmo tempo, com relativa autonomia deste. f uma contradição na produção colonial, pois num caso ou no outro, abria-se à economia colonial a possibilidade de desenvolver um setor de modo autônomo (NOVAIS, 1981, p。96). Este setor, além de assegurar nos períodos de transição de uma produção dominante para outra (da economia açucareira para a pecuária \& desta para a mineira e assim por diante) a continuidade da estrutura produtiva na colônia, garantia alguma forma de capitalização e a reprodução interna das condições de produção 
(FURTADO, 1982, p. 54-60 et passin)。

Indo um pouco mais a fundo nas contradições apresentadas na produção colonial, observa LAPA (I982, p。 45-49) que foi ao lado da economia dominante - a exportadora - voltada para o comércio externo que surgiu uma agricultura de subsistência, da mesma forma com que se gerou um mercado interno. Com isto, não se pretende descondicionar a economia colonial dos mercados europeus, mas mostrar que em seu interior se localizava um mercado interno que por suas proporções não pode ser negado e muito menos ignorado. Se não se pode ignorar que a agricultura de subsistência e o comércio interno complementaram a economia mercantil, por outro lado, não se pode negar que tenham sido fatores de sua deterioração.

A economia colonial caracteriza-se, portanto, enquanto economia mercantil, na qual a produção não concorre, no mercado internacional, com a produção metropolitana. Isto quer dizer, "produção mercantil complementar, produção de produtos agrícolas coloniais e de metais preciosos" (VELIO, 1975,p.30)。 Porém, como bem observou PRADO JR. (1978, p. 119), este caráter de produção mercantil complementar se deu de forma subordinada. Subordinação da economia colonial aos interesses do capital mercantil; subordinação de todos os setores à produção e exportação de produtos coloniais ou do símbolo da riqueza das nações - metais nobres e pedras preciosas.

Além disso, e pelo que já foi exposto, a produção mercantil só poderia existir se as formas de trabalho utilizadas fossem compulsórias ou, na sua forma limite, o escravismo. A explicação desta situação decorre do próprio objetivo primor dial da economia colonial: produzir lucro apropriável pela bur- 
guesia mercantil. A forga de trabalho, portantc, tinha que ser reproduzida com um mírimo possíveI。 Como a existência de terra farta possibilitava que os colonos, caso se transformasser em posseiros ou pequenos proprietários, produzissem sua própria sobrevivência - o que exi firia para o seu assalariamento que a taxa de salário oferecida fosse suficientemente elevada para se constituir em alternativa ao seu auto-sustento - a única saída, aos olhos do capital, foi reinventar o trabalho compulsório, que acabava sendo mais rentável que o uso do trabalho assalariado (NELLO, 1975, p。30-31).

Assim, enquanto na Europa o desenvolvimento do capitalismo promovia a suxressão do trabalho compulsório, fundamëntalmente do trabalho servil, e o adventc do trabalho "livre" (9), a moderna colonização fez renascer, se bem que sob novas condi @ões, o trabalho escravo:

"(...) A escravidão foi o regi-
me de trabalho preponderante na
colonizaça do Novo Nundo, o
tráfico negreiro que a alimen-
tou, um dos setores mais rentá-
veis do comércio colonial. Se à
escravidão africana acrescen-
tarmos as várias formas de tra-
balho comqusório, servil e se-
mi-servil... resulta que estrei-
tissima era a faixa que restava
no conjunto do mundo colonial,
ao trabalho livre." (Novals,
l98l, p. 98 ).

No caso do Brasil, a instalação da produção colo-

(9) Para a passagem do trabalho seriril, típico do Modo de Produç̃̃ Feudal, para a relą̧ão de produção assalariada, onde - trabalnador é "livre" para vender sue força de trabalho, ver MARX (1982, Livro I, VoIs. I e II. ps. 189-190; 828-3I e 879 e so). 
nial - com a agro-indústria açucareira - compeliu, inicialmente, o indígena ao trabalho compulsćrio. A expansão da produção, com o consequente aumento do consumo de força de trabalho escravizada, deu lugar ao tráfico negreiro para o Brasil (FURTADO, 1982, p. 41-42; NOVAIS, 1981, p. 104; PRADO JR., 1979, p. 122). Mesmo com a dominância da escravidão negra, nos setores exportadores, em outras áreas do país, no entanto, o aprisionamento do indígena e sua escravização continuaram a exercer papel importante na esfera econômica, como atestam os exemplos das capitanias de São Vicente e do Maranhão (FURTADO, 1982, p. $41-42$ e 90-91)。

Se se detiver à questão da reinvenção da escravi dão, evidentemente que sua análise no contexto global do desenvolvimento do capitalismo nesta etapa apresenta-se como uma flagrante contradição(10). A produção colonial foi uma pro dução mercantil que ajustando-se ao desenvolvimento do Modo de Produção Capitalista, criou as condições para a expansão do trabalho assalariado. Neste sentido, o regime de trabalho escravista se apresenta como um paradoxo ao próprio capital:tanto a nível do processo produtivo, quanto a nível do próprio mercado. O processo crodutivo sob controle do capital se realiza de forma a que a inversão inicial (capital-dinheiro), se transforme em fatores de produção (capital-produtivo), que quando interagem, produzem mercadorias (capital-mercadoria), que ao se realizarem no mercado, isto é, ao serem vendidas, transformam-se novamente em caxital; não mais no capital inicial, mas num capital acrescido (mais-valia)。 se o trabalho é assalariado, tal acrécimo se faz pela diferença

(10) Sobre as contradições do escravismo, ver CARDOSO ( $1962, \mathrm{p}$. 186 e s.); IANNI (1962, p. 80 e s.) e IANNI (1978, p。 19 e s. e 140 e s.). 
entre a utilização da força de trabalho e sua remuneração (pagamento do salário para que a força de trabalho se reproduza minimamente), que é a própria mais-valia. Se a força de trabaIho é escrava, trava-se a rotação, pois o pagamerto do trabaTho se faz antecipadamente (na compra do escravo) e outra parte deve ser gasta, ainda, para a manutenção da mercadoria-escravo. Assim, a produção da mais-valia estará bloqueada e a reprodução ampliada do capital dependerá exclusivamerte das condições dos mercados. Aqui, novamente, a escravidão se constituirá num bloqueio, pois o escravo não é parte ativa do mercado de consumo. Sua reprodução, em grande medida, não depende do circuito comercial, já que a economia colonial se organizou de tal forma que os próprios escravos prodüiam as condições para a reprodução de sua força de trabalho.

Manifestação da oposição ao trabalho escravo é dada pelos próprios cativos. Enquanto o objetivo primeiro dos senhores, no que diz respeito aos seus escravos, era a extração do trabalho excedente, os éscravos, de sua parte, antes subjugados do que integrados ao regime que os explorava, a ela resistiram das mais variadas formas. Não se pode é evidente, tentār identificar estas resi stências a um movimento histó rico com direção pré-determinada. Antes cabe identificar que esta situação de negação da opressão pôde tanto exaurir-se em pequenos testos, como eclodir sob a forma de rebelião (CASTRo, in IAPA, 1980, p.94).

$\mathrm{Na}$ medida em qúe o capitalismo, em escala mundial, alcança certo grau de desenvolvimento e um certo dinamismo, ele tende a eliminar as condições de existência das relações escravistas de produção. Em outras palavras, o capital industrial passou a influenciar, matizar, alterar ou mesmo 
destruir as formas de organização social e técnicas das relações de produção que não se adequavam ao seu ritmo e sentido. o paradoxo representado pela articulação do trabalho livre, na Europa, com o trabalho escravo, nas colônias, revela-se uma contradição estrutural significativa, que tem que ser eliminada (IANNI, in IAPA, 1980, p. 164-165)。(II)

Retomando a caracterização inicial do Antigo Sis tèma Colonial, é possível reconhecer que houve uma conjugação entre diferentes níveis ou instâncias (econômica, social, jurídica, etc.) que garantiu o equilíbrio do próprio sistema, enquanto foi necessário. Assim, o capital que comandou o processo foi o comercial e a burguesia comercial quem dominou as forças produtivas; o regime político foi o absolutismo real e a sociedade se caracterizou por uma diferenciação marcadamente estamental; a doutrina econômica que regia o movimento do capi tal comercial na implantação e expansão do sistema colonial, o mercantilismo. Os mecanismos que asseguravam esse funcionamento iam da pretensa legitimidade política à legislação, da doutrina à prática econômica e política, das tensões aos movimentos sociais, que restabeleciam o equilíbrio e asseguravam a continuidade do processo de acumulação primitiva (IAPA, 1982, p. 17, 28, 36). Disto advém a especificidade da economia colonial, que residiu na produção mercantil e, ao mesmo tempo, no trabalho compulsório.

(II) Voltar-se-á oportunamente a tratar da contradição representada pela escravidão e que o capital industrial historicamente eliminou, quando se tratar "a crise da economia mercantil-escravista e a emergência do trabalho assalariado"。 
Em outras palavras, a produção mercantil realizada sob trabalho servil ou a produção mercantil realizada sob trabalho escravo fcram reinventadas para propiciar o máximo de acumulação primitiva de capital e, assim, estimular a transição do feudalismo para o caritalismo, conforme evidenciam vérios estudos (12). o que existe, portarto, é a dominação de um processo produtivo, cujos rumos são determinados pelas contradições que animam as economias metropolitanas (NELLC, 1975, p. $33-34$ ).

Esta situação coloca uma outra faceta do caráter das economias e sociedades coloniais: são subordinadas a uma determinação das economias metropolitanas, uma vez que a apropriação e controle do excedente estavam nas mãos da burguesia metropolitana, o que impossibilitava uma acumulação autônoma na colônia (NELIO, 1975, p. 32)

Estas consideraçoes dão base para que se retore 0 caráter propriamente capitalista da economia colonial. Nela existia o modo de produção capitalista, se bem que de maneira formal (13). Mas, este caráter capitalista das economias coIoniais não the era dado somente pelo fato de sua produção ser mercantil e do lucro ser o objetivo almejado; também, não era dado somente pelo fato da economia colonial participar do mercado internacional. O aue caracterizava o capitalismo da coló-

(12) De modo especial, ver: MAPX - o Capital (1982), livro I, vol. II, p. 828 e s; MARX - Formaçoes Econômicas Pré-Capitalistas (1981), p. 117 e s; NOVAIs, 1981, p。 57-116; CARDOSC, I973, p. II e s; IELLO, 1975, p. 24-26 e 31-35.

(13) Isto já havia sido notado por Marx quando analisou as origens da acumulação primitiva de capital (o Capital: Iivro I, vol. II, cap. XXIV, $p$ 828-882) e a "teoria moderna da Colonização" (Idem, cap. XXV, p.883-894)。 
nia era o de se constituir em instrumento de acumulação primitiva. É por isso que a escravidão é escravidão reinventada, que o comércio é comércio monopolizado (INEILO, 1975, p.35).

Dito de outra forma, como bem observa IAPA, o sistema colonial viabilizou a transformação do capital em capital industrial, na medida em que ajudou o capital comercial a vencer as resistências do sistema feudal, servindo de mediador dos centros produtores e seus respectivos mercados. Bem se sabe que este processo histórico foi longo, mas, no seu avanço, lenta e inexoravelmente, subordinou o capital mercantil ao capital industrial e, atravessando todo o período da colonização, fez emergir as nações industriais como hegemônicas, em detrimento das demais nações comerciais. É neste sentido que o sistema colonial se caracteriza como um sistema de transição entre o modo de produção feudal e o modo de produção capitalista, que propiciou transformações estruturais qualitativas (LAPA, 1982, p. 12-19).

Com o advento da grande industria, a acumulação de capital se dará por"mecanismos que se realizam no bojo das forças produtivas capitalistas, deixando de necessitar de apoio externo. A interação que antes havia entre a economia colonial e a economia mercantil, passa agora a guardar profunda contradição (NELLO, 1975, p. 35-36).

\subsection{A Política e a Prática Indigenista no Período Colonial}

Pelo que se viu anteriormente, a empresa colonial portuguesa, em terras sul-americanas, foi totalmente subordinada acs interesses do capital mercantil, cumprindo o papel 
que The foi destinada.

Durante os primeiros decênios do século XVI, a política indigenista para o Brasil foi condicionada pelo caráter da expansão ultramarina: os portugueses vieram à América com os mesmos interesses que impulsionavam toda a Europa ao Oriente, isto é, estabelecer contatos comerciais com os povos dos países e continentes (THOMAS, 1982, p. 27)

A ocupação do território brasileiro, da forma como se processou, pressupunha que ele estivesse vazio de ocupação e inexplorado, sendo todo modo de vida autóctone considerado inútil e indesejável. Porém, a maneira de tornar viável a empresa mercantil e escravocrata, era a mão-de-obra indígena: todas as penetrações dependeram do índio, do seu conhecimento da mata, de sua habilidade como agricultor, caçador, pescador, canoeiro, guerreiro, artesão, etc. (RIBEIRo, 1983, p. 53).

Nesta forma de ocupação inicial, os brancos eram em pequeno número e podiam ser incorporados à vida social aborígene ou se acomodavam às exigências dela.

" (...) o intercâmbio econômico, nessas condições, não exigia a permanência de um grande número de estranhos nos grupos locais, - que dava aos nativos a possibilidade de impor sua autoridade e seu modo de vida. Os brancos viviam nos grupos locais, literalmente sujeitos à vontade dos nativos; ou se agrupavam em feitorias, dependendo tanto sua alimentação quanto segurança do que decidiam fazer os "aliados" indígenas. (...) (FERNAN DES, 1975, p.22). 
Esta situação existia principalmente quando a atividade econômica estava baseada no escambo. É evidente que o escambo envolvia um padrão de relação social aprendida sob a influência do branco. Foi até mesmo, aurante certo temoo, fomentado pelos próprios indízenas, devido à importância que atribuíam aos objetos e produtos oferecidos pelos europeus. (Idem, p. 23).

Para aqueles que viviam agrupados em feitorias, as condições de dexendência perante os nativos eram idênticas. o Índio era a fonte de alimentos, dos produtos para a exportação, da pouca segurança existente face a outras tribos hostis e de brancos pertencentes a outras nacionalidades inimigas. Como não possuíam mulheres brancas, suas companheiras eram obtidas por arranjos com os indígenas.

Além dos interesses econômicos, outras razões haviam e que esclarecem a posição da Coroa Portuguesa em relação aos Índios: desde o começo, as viagens comerciais portuguesas estiveram ameaçadas pela concorrência dos navegadores franceses.

Mas mito mais do que os danos econômicos provocados pelo tráfico dos franceses, estava a ameaça contra o domínio lusitano. Este duplo perigo provocou o Governo português a realizar esforços para ganhar os Índios como seus aliados (THO MAs, 1982, p. 28-32).

Quando, porém, os portugueses passam a substituir - escambo pela agricultura, alteraram, também, seus centros de interesses no convívio com o iná́gena. Esse passou a ser encarado como um obstáculo à posse da terra, uma fonte desejável e insubstituível de trabalho e a única ameaça à segurança da coIonização. Passava-se, assim, do período de tensões encobertas 
para a era dos conflitos abertos com os índios (FiRINAIDES, I975, p. 25-27).

Como se viu arteriormente, a empresa colorial encontrou na agro-indústria açucareira sua primeira base econômica, em conformidade com os princípios mercantilistas. Assim, junto com o latifúndio e a monocultura canavieira, espalhou-se a escravidão dos índios (mais tarde dos negros) como uma necessidade econômica.

Justificar a escravidão e os métodos usados na escravização dos indígenas não foi tarefa difícil, já que estava disseminado na ideologia dominante que somente a escravidão dos indígenas era capaz de fazer-lhes abandonar o seu modo de vida "selvagem", "pagão", baseado na "vadiagem" e na "preguiça", vindo a familiarizá-los com a "civilização européia" e com o "cristianismo"。

Assim, a escravidão era encarada como algo completamente natural na ideologia da metrópole, encontrando uma rápida difusão na colônia. Os escravos índios, tratados como objeto, foram vendidos, negociados, servindo até para o presen teamerito. Eșta forma de escravidão foi adotados por todos os agentes envolvidos na colonização, leigos e clérigos (THOMAs, 1982, p. 39-46).

Inicialmente, para a obtenção de escravos, os ocupantes portugueses aproveitaram-se dos costumes indígenas. As guerras constantes entre índios, provocavam a prisão de muitos inimigos. Estes prisioneiros foram designados pelos portugueses como "índios da corda", sendo que os colonizadores brancos obtiveram muitos desses prisioneiros através da troca por mercadorias européias. Essa prática foi chamada de "resga- 
te": como o comprador "salvava" da morte os índios da corda,os colonizadores acharam justo condenar os que eram assim conseguidos a uma escravatura temporária ou vítalícia. Esta prática era respaIdada pelo direito portuguès que considerava os írdios assim obtidos como "escravos legais"。( $(14)$

Desde o início da o cupação portuguesa no Brasil, outro método de escravização foi amplamerte utilizado: caçadores de escravos armavam navios com os quais percorriam as costas da colônia, surpreendiam os índios, escravizavam-nos e os vendiam aos engenhos do país. Essas investidas passaram a ser conhecidas como "saltos" e suas conseqûerrcias foram amplas: gerou un estado ininterrupto de guerras entre índios e portugueses, que acabou por condicionar as relações entre ambas as etnias.

Este estado de guerra propiciou o uso de outro artifício para o aniquilamento dos índios e/ou para a escravização dos mesmos: a "guerra justa".

A fundamentação jurídica e doutrinária da "guerra justa" não era nova, estando definida em Portugal desde o século XIV. Sua formulação era baseada no "direito de guerra medieval", tal como se encontra no Decreto de Graciano, e na doutrina de Santo Tomás de Aquino. Basicamente ela acentua o direito de se declarar uma guerra contra os pagãos; sendo a

(14) A expressão "resgate" designava, de modo geral, troca ou exercício do comércio e referia-se, já no século XV, aos métodos comerciais dos portugueses na ffrica. Em relação ao Brasil, o resgate aparece pela primeira vez no regimento do Bretoa de 1511. Posteriormente, passou a aesignar o objeto trocado ou vendido aos indígenas, como sinônimo de mercadoria. A partir de ambos os significados, a palavra evoluiu de forma a designar os métodos de aliciamento de escravos (THOMAS, 1982, p。48-49). 
guerra contra os pagãos "justa", era dado o direito de saquear e escravizar os pagãos (THOMAs 1982 , p. 50-51).

Esse ponto de vista explica de forma a equada a conduta dos ocupantes do Brasil com relação aos indígenaso Niesmo que as circunstâncias da América fossem diferentes da Africa ou da Esia e mesmo que os motivos da "propagação da fé ou da segurança do comércio livre" fossem historicamente diferentes, esta era no fundo a justificativa mais importante para se travar guerra contra os indígenas e a escravizá-los。

Quando os índios das regiões costeiras do Brasil já haviam sido praticamente exterminados ou transformados em escravos para as plantações ou, como em muitos casos, rechaçados para o sertão, as expedições dos portugueses - chamadas "entradas ou bandeiras" - conseguiram apoderar-se no interior do país dos escravos índios de que os colonos precisavam em suas plantações.

O nome "entrada" procede da expansão portuguesa na Africa, quando assim eram denominadas as expedições que, desde meados do século XV, apresavam escravos nas costas africanas no interior, e os verdiam na metrópole. O termo "bandeira" designava em Portugal, durante o período medieval, uma unidade militar composta de cinco ou seis lanças, cada uma com seis homens. Várias bandeiras compunham uma companhia”. A partir da legislação militar de D。 Sebastião, de 1570, ambas as expressões passaram a ser usadas como sinônimas.

No Brasil, essas palavras passaram a ser usadas quanão a expansão para o interior fọi se reforçando, e as unidades defensivas serviam para o ataque, a exploração da terra e a escravização (THOIMAS, 1982, p. 54-55)。 
Pelo que se viu, pode-se dizer que o processo de ocupação capitalista no Brasil, sempre teve que contar com a expropriação da terra e a "desirfeç̧̃o" de seus moradores indígenas, exterminados ou transfurmados em escravos. A colonização subentendia, portanto, conflitos entre colonizadores e indígenas. Para justificá-los, os representantes da "civilização" lançavam mão de vários axtifícios: os estereótipos àe tribos inimigas, ferozes, bárbaras e pagãs, com os quais justificavam suas investidas contra os povos tribais; ademais, contavam de antemão com a vitória certa, garantida pela supremacia militar; finalmente, tirham a sarartia do apoio oficial da coroa em armas, homens e, principaimente, na adoção de uma política que, além de thes ser favorável, era respaldada por um aparato legal (ver Apêndice I)。

Neste sentido, a política oficial em relação aos inäígenas, sempre beneficiou os colonizadores, representados pelos segmentos da população colonial que adentravam pelo território nacional; jamais os indígenas, vistos sempre como um empecilho ao desenvolvimento da "civilização cristã"。A esta cabia a tarefa de submetê-los, cristianizá-los, impor-lhes os "benefícios da civilização"; finalmente, trazê-los para o convívio dos "brancos" como "fiéis vassalos"。

Embora o anseio de submeter o ináígena teinha sido - elemento central da ideologia dominante no mundo colonial lusitano, na prática, esse elemento sofria gradações, provocadas por interesses e valores sociais que dirigiam a atuação dos indivíduos pertencentes aos diversos sesmentos da sociedade colonial em formação (FERNANDES, 1975, p。25)。

Para o colono, submeter os indígenas equivalia a reduzílos ao mais completo e abjeto estado de sujeição: to- 
mando-lhes as terras, quen fossem "aliados" ou "irimigos"; convertế-Ios à escravidão, para dispor de suas pessoas, de suas coìsas e de suas muireres; tratá-los como seres sub-humanos e negociá-los ( Idem, p.25).

Para o administrador ou agente da coroa, que compartilhava e comungava dus interesses dos agentes colonizadores, por causa da pressão das circunstâncias, impunira-se pradência no trato indígena: todas as concessões podiam ser feitas aos colonos, mas de modo a resguardar certos interesses que dessem à Coroa a possibilidade de utilizar as tribos indígenas "aliadas" como instrumento de conquista e controle dos territórios ocupados (Idem, ibidem, p。25-26).

Finalmente, havia os jesuítas, cujas atividades freqtentemente contrariavam os interesses dos colonos e, mesmo, as conveniências da Coroa, mas que concorriam para a destruição das bases de autonomia das sociedades tribais e reduzir as populações nativas à dominação colonial (Idem, ibidem, p。26).

Isto indica claramente que todos os agentes estavam envolvidos com o projeto colonial oriundo da metrópole por - tuguesa. Assim.é que cada um destes agentes - o colono, o missionário e o representante do poder político e militar da Coroa - teve de manobrar, ora aliando-se, ora combatendo-se mutuamente.

O Estado português, quase sempre, atuou como elemento de equilíbrio, com vistas a diminuir os conflitos entre seus três agentes colonialistas. Desta situação, em conformidade com as pressões que recebia, a Coroa pendia para um lado ou para outro (RIBEIRO, 1983, p. 53).

Esta cscilação entre interesses diferentes no trato com os irdígenas está refletida nitidamente nas leis pro- 
listas começaram a realizar suas expediçoes contra os índios do interior, com a finaliāade básica de obter escravos (Idem, p. 180).

INo século XVIII, a economia colonial brasileira se caracterizou pela exploração mineira. A luta se dava entre "brancos" e índios que habitavam as regiões auríferas: Minas Gerais, Goiás e Mato Grosso. INo Maranhão, os criadores de gado invadiram as terras dos índios Timbira, continuando sua marcha pela região central do Brasil, lutando agora com os Kayapó e Akwẽn (Idem, ibidem, p. 180).

De modo geral, pode-se inferir que a ocupação das terras pela "civilização européia", significava para os índios a invasão de suas terras e expropriação delas. Ao mesmo tempo, a implantação da colonização, por suas próprias características, levava a população indígena a ter esta consciência do processo que a submetia, conforme pode-se perceber por um trecho de Momboré-açi, da tribo Tupinambá, relatado por ABBEVILIE:

"Vi a chegada dos peró (portugueses) em Pernambuco e Potiú; e comę̧aram eles como vós, frari ceses, fazeis agora. De início, cs peró não faziam senão traficar sem pretenderem fixar residência. Nessa época, dormiam livremente com as raparigas, o que os nossos companheiros de Pernambuco reputavam grandemente honroso. Mais tarde, disseram que nos devíamos acostumar com eles e que precisavam construir fortalezas, para se defen derem, e edificar cidades parā morarem conosco。 E assim parecia que desejavam que constituíssemos uma só nação. Depois, 
começaram a dizer que não podiam tomar as raparigas sem mais aquela, que Deus somente lhes permitia possuí-las por meio do casamento e que eles náo podiam casar sem que fossem batizadas. E para isso eram necessários paí. Mandaram vir os paí; e estes ergueram cruzes e principiaram a instruir os nossos e a batizá-los.Mais tarde afirmaram que nem eles nem os paí podiam viver sem escravos para os servirem e por eles trabalharem. E, assim, se viram constrangidos os nossos a fornecer-lheso Mas, não satisfeitos com os escravos capturados na guerra, quiseram também os filhos dos nossos e acabaram escravizando to đa a nação; e com tal tirania e crueldade a trataram que os que ficaram livres foram, como nós, forçados a deixar a região." (Apud FERNANDES, 1975, p。29).

A reação dos índios à expansão colonial, assumiu três formas bésicas: a de preservaçãc da autonomia tribal por meios violentos; a submissão nas condições de "aliados" e de "escravos"; de preservação da autonomia tribal por meios passìvos, que assumiu a feição de migrações para as áreas em que os brancos não pudessem exercer dominação efetiva (FRRNANDES, 1975, p. 27).

A primeira forma de reação pode ser exemplificada pelo que se tem chamado de "Confederação dos Tamoios". Inicialmente, a desvantage tecnol'́cica dos indígenas pôde ser compensada pela supremacia advinda da preponderância demográfica e pela tática de guerra adotada, combinando o ataque simultâ- 
neo a diversas posições dos brancos, tanto no litoral quanto no planalto. No entanto, o êxito dos índios foi parcial e eféemero. A organização tribal impediu a formação de um sistema de solidariedade supratribal, exigido pela situação. As alianças fragmentaram-se e a luta contra o invasor retornou ao antigo padrão dispersivo, que acabava jogando índios contra índios, acabando por beneficiar os brancos ( $I d e m, p_{0} 27-28$ ).

A segunda forma de reação foi posta em prática principalmente pelos Tupi em todas as regiões do país, ora sob - influxo dos jesuítas e das garantias formais das autoridades; outras, como decorrência da derrota em "guerras justas"。 As condiçc̃es a que foram submetidos - doenças contraídas nos contatos; a escassez de víveres; o trabalho forçado; a atuação como "aliados" nas guerras promovidas por portugueses - acabaram operando como verdadeiro "sorvedouro de seres humanos" (Idem, p. 28).

A terceira forma de reação, constituiu a maneira típica de acomodação desenvolvida pelos nativos, na tentativa de controlar os efeitos da invasão. Trata-se de um controle de natureza passiva, que transforma o isolamento em fator de defesa da autonomia tribal. Porém, esta forma de reação tinha pouca eficiência, dada a grande mobilidade que caracterizou 0 processo de colonização portuguesa no Brasil (Idem, p. 29).

Direcionando mais a questão indígena aos objetivos do presente trabalho, deter-se-á a análise na situação indigenista de Goiás. Historicamente, a problemática se conformou desde o final do século XVI, quando as populações indígenas que tinkam seus habitats na recião que hoje compreende Goiás, foram duramente agredidas pelas bandeiras que se organizavam 
com a finalidade primordial de aprisioná-los e, secundariamente, para encontrar possíveis minas de metais e pedras preciosas. Munidos de armas de fogo, os bandeirantes caíam sobre as aldeias matando quantos fosse possível e, prendendo os sobreviventes, conduzia-os ao litoral como escravos (ALANCASTRE, $1864, \mathrm{p} \cdot 14-15)$.

As consequências destas frentes do bandeirismo sobre as tribos existentes podem ser facilmente deduzidas: sempre procurando fugir destes inimigos, houve grande mobilidade horizontal; o extermínio ae grupos tribais inteiros, ou de parte da população tribal com conseqtências em suas respectivas organizações sociais (RAVAGNANI, 1978, p. 9-10)。

Quando do encontro de ouro em Goiás, em 1725, iniciou-se o povoamento da área e a situação tende a ir se alterando em alguns pontos, ainda que inicialmente o índio tenha continuado a ser objeto de contínuos ataques. Tais circunstâncias ocorriam a despeito da legislação existente: a Carta Régia de 21 de abril de 1702 que continha proibição expressa ao cativeiro indígena, ainda que fizesse exceção ao cativeiro por tempo limitado para quem os houvesse pacificado; a Carta Régia de 10 de junho de 1726 que reafirmöu a proibição, embora permitisse aos governadores dar os índios para trabalharem a pessoas de reconhecida confiança, a troco de um salário (ver o Apênaice 1).

$\mathrm{Na}$ medida em que as descobertas mineiras se ampliavam, as bandeiras se organizavam não mais com o objetivo primeiro de aprisionarem silvícolas. As minas que encontravam constituíam melhores atrativos econômicos. Desta forma, o bandeirantismo prosseguia, mas com a finalidade primordial de descobrir novas minas. Embora visassem o encontro de veios aurí- 
feros, estavam também precarados para atacar as tribos indígenas que porventura encontrassem, deixando a região "Iimpa" para a ocupação. Para o índio, portanto, a situação pouco se diferenciava da anterior.

Esta nova situação teve início concomitantemente com a fase do povoamento, que ao estabelecer inúmeros arraiais próximos à Vila Boa, fez com que os nativos buscassem refúgio no interior; os que permaneciam em suas terras acabavam sendo objeto de perseguição. Nesse seritido, os documentos citam algumas expedições incentivadas por D. Iuiz Mascarenhas, então governador de São Paulo e Goiás, destinadas a explorar ouro e "desinfetar" algumas regiões habitadas por tribos consideradas hostis; em alguns casos chegavam a "contratar" tribos já pecificadas para submeter a outras, como é o caso da contratação em 1742 de quinhentos Bororo para limpar a zona habitada pelos Kayapó (RAVAGNANI, 1978, p. 22-23 - nota 25).

A posse do primeiro governador da província de Goiás, D. Marcos de Noronha, em 1749, coincidiu com a decadência dos novos achadosie o. financiamerto e organização das bandeiras pela própria administração. Com tais medidas, as buscas acabaram atingindo as regiões onde os nativos haviam se refugiado, ampliando o número dos conflitos (Idem, p. 12). A cada recuo da mineração correspondia um avanço do bandeirismo, sendo invitáveis os confrontos sendo que a posse do território tribal era móvel dessas ações (Idem, ibidem).

Mais uma vez estava declarada guerra ao índio e agora com o apoio oficial. A primeira "vitória" conseguida, contra os índios Kayapó, incentivou os povos dos arraiais a contratarem sertanistas experimentados; além do mais, entrava 
em cena um novo elemento que passou a ser utilizado em terras goianas, ainda que o método já tivesse sido amplamente utilizado no passado e em outras regiões: o apoio de uma tribo no combate de outra.

Por essa época já existiam alguns aldeamentos, aos quais D. Marcos de Noronha deu um regimento: tratava-se de um severo regimento militar imposto a todos os moradores aldeados - militares, civis ou índios. Pelo seu absurdo, causou a revolta e fuga dos habitantes indígenas e jesuítas. Isto se deu malgrado toda a tentativa de se regularizar as relações entre índios: a Provisão de 08 de maio de 1746 criou em são Paulo uma junta de missões destinadas a regular todos os assuntos relativos aos índios; em 17 de junho de 1747 deu várias providências acerca dos aldeamentos; em 30 de maio de 1753, ordenou que se enviassem os índios domesticados com seus respectivos missionários ao centro das tribos selvagens para chamar seus irmãos à civilização; em abril de 1755 deu preferência para a o cupação de empregos aos que se casassem com índias; a Iei de 06 de junho de 1755 deu liberdade aos índios do Pará e Marae no Alvará de 08 de maio de 1758 estendeu esta liberdade a todos os índios do Brasil (RAVAGNANI, 1978, p.23-24 - nota 29).

Os documentos, de modo geral, tratam os diferentes grupos tribais genericamente de "gentios", não se preocupando em especificar o nome tribal, com raríssimas exceções. Informações mais específicas surgem no segundo governo de D. João Nianoel de Niello, que governou a província de Goiás de 1759 a 1770 .

Em 1762, numa carta deste governador (Apud RAVAGNANI, 1978, p. 14-15), encontra-se noticiado que a tribo Xa- 
vante invadiu a região dos povoados de Crixás, Tesouras e Niorrinhos e, contra seu antigo costume, causaram mortes e destruições, sugerindo que estes índios foram mandados pelos Jesuítas das missões espanholas. Os habitantes pediram socorro ao governador e este os autorizou a formarem uma bandeira, com o auxílio dos moradores de Anta e Pilar, com os objetivos: primeiro "desinfetar" a área dos "Kayapó, Xacriabá, Acruá e Xavante" e, segundo, explorar a área para ver se encontravam algum descobrimento de metal nobre ou pedra preciosa.

Em outra carta endereçada ao. Secretário de Estado Francisco Xavier de Niendonça Furtado, de 7 de junho de 1764, o governador (apud RAVAGNANI, 1978, p. 15-16) fez as mesmas observações informa da decisão dos moradores de Pilar, unidos com os de Crixás, armados às suas próprias custas e com licença da autoridade, de organizarem uma bandeira para castigarem as "crueldades" que os Xavantes executaram na região.

Quase um ano depois, em 30 de março de 1765, voltou o governador a informar ao secretário que, quando estava sendo organizada a bandeira, os Xavante voltaram a atacar. Diante de "mais essa ofensa", que punha risco a própria economia da província, a bandeira partiu e quando avistaram uma aldeia muito populosa, atacaram e mataram "muitos bárbaros", sendo que os demais fugiram (Apud RAVAGNANI, $1978,2.16-17)$.

Em outra carta de 21 de fevereiro de 1769, torna 
- governador a acusar os Xavante e Kayapó de responsáveis pela situação em que se encontra o arraial de Tesouras (Apud RAVAGNANI, 1978, p. 17).

A significação destas cartas, em termos de política indigenista, é muito jem captada pelo autor de A experiência Xavante com o Mrundo dos Brancos:

"As intensões do Eovernador são claras. Precisava justificar em Portugal a invasão de novas terras e o inevitável choque com a tribo aí localizada. Na última década, a política indigenista portuguesa mudara devido à presença do Marquês de Pombal. Como os Jesuítas tinham sido expulsos de Portugal e suas colônias, era confortável acusá-los de instigadores de tribos até então pacíficas. Uma vez transformadas em agressivas, estava justificada e legalizada a guerra ofensiva. (...) As preocupações de aue se cercou para explicar ao rei sua atitude. demonstram a nova mentalidade reinante na metrópole, mas ainda incompreensível e impraticável na colônia. (...)" (RAVAGNANI, 1978, p。17-I8 - o grifo é nosso)。

Após a colonização de Goiás, conforme ficou evidenciado anteriormente, o grande afluxo de migrantes fez com que os grupos tribais fossem se afatando das áreas que passavam a ser ocupadas, mesmo os mais significativos em termos numéricos. Com a decadência das minas, a solução era procurar novas jazidas; com isto as frentes de expansão dirigiram-se cada vez mais para o centro da região. As tribos, impossibili- 
tadas de novos recuos, pois os territórios tribais já se apresentavam muito reduzidos, não restou outra alternativa senão a submissão ou o conflito.

Em 1772, assume o governo D. José de Vasconcellos, quando a situação econômica tornava-se cada vez mais grave. Em Portugal, o Marquês de Pombal enviou novas recomendações sobre - relacionamento com os indígenas.

Estas recomendações mudavam por completo os termo: da política oficial que deveria ser seguida em relação aos índios: substituía-se a guerra pela brandura; o extermínio e escravização pela pacificação e aldeamento. Porém, os contínuos a taques dos Xavante, Acroá, Carcabás e Kayapó aos arraiais mais próximos de seus habitats, bem como o costume de respondê-los com a "guerra defensiva", e a legislação dos governos anteriores ainda não revogadas, permitindo atacá-los, deixavam D. José sem meios de se impor e bastante confuso。

Durante seu Eoverno, procurou D. José de Vasconcellos cuidar dos atrativos da mineração, promovendo a partir de 177.4 diversas bandeiras com este fim. Tinham o mesmo objeti.vo que as anteriores em relação ao ouro, mas nova era a orientação em relação aos índios.

Como foi visto anteriormente, estas bandeiras pouco ouro encontraram, porém subjugaram e aldearam milhares de Índios: da bandeira que partiu de Traíras ao Araguaia, obteve-se a amizade das tribos locais: uma nova expedição à região, no ano de 1775, trouxe índios Javaé e Karajá para a aldeia de Sant'Anna. outra que seguiu em direção aos Martírios, Araés e Rio Branco, "selou a anizade" com os nativos do Araguaia, deixando livre a navegação por este rio. Com isto, o governador 
fundou diversos aldeamentos, para onde foram sendo levadas as tribos que foram subjugadas. Os antigos aldeamentos, criados no governo de D. Marcos Noronha, em completa decadência, foram reformados e povoados. O rígido regulamerto a que estavam sumetidos desde 1754, foi substituído por outro, inspirado nas novas instruções. Porém, em essência, o objetivo prático do indigenismo continuava o mesmo: expropriar os índios de suas terras, transformar seus hábitos e cultura e prepará-los para sua posterior incorporação à classe dominada, como força de trabalho disponível.

Com a subida ao trono de D. Maria I não se alterou a política indigenista para o Brasil. O mesmo ocorreu na província de Goiás, onde o novo governador, D. Luiz da Cunha Menezes, continuou o trabalho iniciado por seu antecessor. Tentou reativar a mineração organizando algumas bandeiras. Pelos fracassos obtidos, acabou dedicando-se à pacificação e aldeamento das populações indígenas。

Conseguiu a pacificação dos Kayapó, grupo que criou muitos problemas à província, construindo para eles a Aldeia Maria I (RAVAGNANI, 1978, p. 38)。

A amizade dos Kayapó animou os habitantes do norte a insistirem junto ao governador na necessidade de pacificar os Índios Xavante. Convencido da urgência e necessidade de trazê-los para o convívio pacífico, iniciou os preparativos para a conquista, porém a morte do chefe da bandeira, quando estava para se iniciar o trabalho, frustrou seu plano.

Sucedeu a este governador, seu irmão Tristão da Cunha Menezes, que levou avante o trabalho de conquista dos índios.

Passa, então, o governador a empreender a prepa- 
ração para a conquista dos Xavante. Nesse interim, chegou a notícia da invasão destes ínaios nas terras contíguas ao Arraial de Crixás e do assassinato de doze portugueses. A reação é imediata:

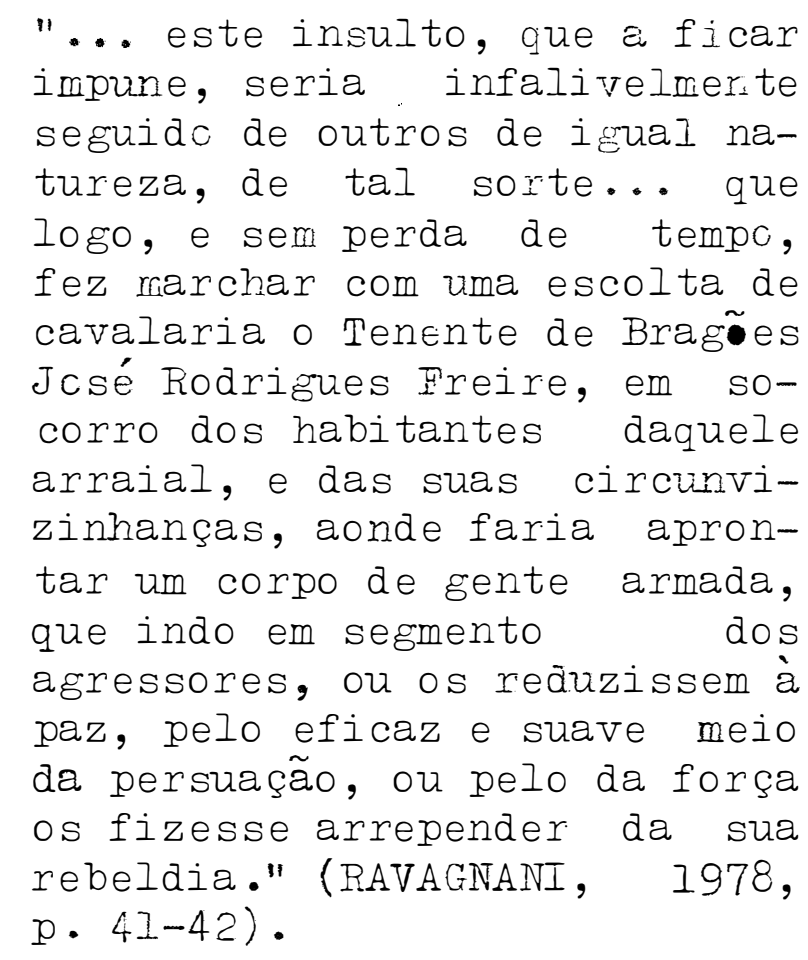

Os Xavante acabaram cedendo, e foram pacificados. Entraram na aldeia de Pedro III no dia 7 de janeiro de 1788 em grande multidão. Com eles vieram quatorze "brancos" que se achavam prisioneiros.

Evidentemente, a pacificação não facilitou somente a atividade comercial, mas abriu o território Xavante à exploração dos colonizadcres. A terra, na verdade, era a grande alavanca; sua expropriação significava a possibilidade de explorá-la, pelo que se imaginava que pudessem possuir em riquezas minerais, bem como à sua ocupação por outras formas de exploração ecchômica, que já se delineavan com a decadência da mineração: a agricultura e a pecuária. 
Os Xavante entraram para o primeiro grande "convívio pacífico", num momento em que a economia regional seguindo os passos da nacional, estava em pleno declínio. Por uma série de motivos, a permanência que teriam nos aldeamentos seria curta.

Nota-se que o período de apogeu dos aldeamentos foi curto e limitou-se a duas décadas: de 1770 a 1790. Este apogeu caracterizou a necessidade de redução das tribos numericamente grandes e estereotipadas como altamente "ferozes. Esperava-se "cristianizar" o "selvagem para depois aproveitá-Io na agricultura, navegação e povoamento de imensos espaços vazios. Porém, a expansão e manutenção desses aldeamentos e seus destacamentos militares, bem como as novas conquistas, implicavam gastos vultuosos para os cofres reais - sem nenhuma condição de suportá-los.

Nesta época, uma verdadeira situação de miséria pairou sobre a Província de Goiás, causando o fim da política de aproximação com os indígenas e sua concentração em aldeamentos oficiais, que em poucos anos foram relegados a um total abandono. Os índios que conseguiram sobreviver da fome e das epidemias, foram gradativamente retornando aos seus antigos territórios tribais. Por outro lado, também a população centralizada nos arraiais se dispersou pelo território, sempre em direção ao norte, dando origem a novas atividades econômicas como a agricultura e a pecuária, com a conseqtuente ruralização da vida na província.

Estava, pois, armado o cenário para mais conflitos entre Índios e colonos. A muāança na política inâigenista não se fez esperar: em apoio às frentes de expansão agro-pecuária,o Príncipe Regente, em Carta Régia de 5 de setembro de I8Il, autorizou a 
guerra contra os Índios Karajá, Apinayé, Xavante, Xerente e Canoeiro. Frn outras Cartas Régias e instruções do Príncipe Regente, autorizava-se a organização de bardeiras encarregadas de fazer guerra ofensiva contra os índios (MOREIRA NETO, 1971, p. 193)-(Ver Apênaice 2).

Como nos demais períodos da história do desenvolvimento econômico brasileiro, voltaram a caminhar de mãos dadas os interesses econômicos e os instrumentos de dominação emanados pelo poder político-jurídico.

3.3. Os Xavante em Goiás

Segundo a tradição Xavante, o local originário da tribo foi "HOYWANA'RADA, OPÒRE", que significa: do Oriente, do mar. Em suas lendas, a lembrança do mar é muito viva (GIACCARIA e HEIDE, 1972, p. 13)。A tradição oral do grupo assim sintetizou os últimos séculos de sua história:

"Antigamente os xavantes habitavam em U'RERE e os brancos vieram morar entre os xavantes e no início pareciam bons. Davam-Ihes presentes. Depois os brancos falaram entre si: - Maltratemos os xavantes e roubemos as suas muIheres. E os xavantes perceberam que os brancos queriam fazer-lhes mal e disseram: - Façamos também nós mal a eles; matemos os seus porcos. Os dois chefes Xavantes contaram aos brancos que os xavantes matavam os porcos e assim os brancos atacaram e prenderam os Xavantes. Assim os Xavantes foram expulsos de URERE. En- 
tão os Xavantes disseram: -Matemos os dois chefes, que estão conosco e não nos defendem. O Erupo fica aqui em casa, enquanto nós vamos esconder-nos na mata onde passam os dois chefes。 Quando os dois chefes passaram lá, foram presos e mortos, também os seus amigos e uma mulher que queria defendê-los. Depois os Xavan tes foram mais para a frene construíram outro acampamento. Um outro grupo de bran cos seguiu-os. Os. Xavantes estavam cobrindo as choças com palha seca e os brancos alcançaram-nos onde estavam. E aqui os brancos, disparan do, mataram muitos Xavanteso O grupo de Xavantes que vivia com os brancos, ajudava a matar e quaise foram massacrados。 Dois Xavantes homens escaparam; enquanto as mulheres foram levadas pelos brancos. Esses dois homens foram para outros lugares e encontraram outras tribos, até encontrarem os Xavantes". (Apud GIACCARIA e HEIDE, $1 \overline{972}$, p. 13)。

São estes caminhos de uma história marcada por conflitos entre brancos e índios, índios e índios, que a tra dição oral dos Xavante tão bem soube captar, que se tentará desvendar. 
Como foi dito anteriormerte, a maioria dos documentos reveladores dos dois primeiros séculos da ocupação do território nacional brasileiro (obras de viajantes, missionários, bandeirantes e documentos oficiais), tratavam as populações indígenas genericamente de "gentios", não se preocupando em especificar o nome tribal. Por isso não se encontra uma única referência aos Xavante até a metade do século XVIII, quando já se encontravam no Estado de Goiás, "distantes mais de mil quilômetros do mar...." (GIACCARIA e HEIDE, 1972, p. 14).

Pelo que se viu dc processo de ocupação e expansão econômica nacional, pode-se, com alguma margem de segurança, fazer inferências dos contatos que os índios Xavante tiveram com estas frentes.

Considerando-se que a tradição oral deste grupo reflete, pelo menos, os grandes movimentos migratórios que tiveram, pode-se pressupor que quando da implantação da empresa colonial, através da agro-indústria açucareira, estes índios habitavam uma parcela de território da Floresta Átlântica do Recôncavo Baiano. Como se indicou anteriormente, o. maior centro de produção açucareira concentrou-se na Bahia, em torno da Bahia de Todos os Santos, onde se instalaram e expandiram os latifúndios monocultores (PRADO JR, 1982, p. 39)。 Com a grande propriedade, conhece-se a reinvenção do trabalho escravo. Como Portugal não contava com população suficiente para abastecer a colônia (PRADO JR., 1982, p. 34), e como a mão-de-obra africana ainda estava fora do alcance dos senhores de engenho, recorreu-se ao trabalho indígena, sob a forma de trabalho compulsório, facultando aos donatários o privilégio de poder escravizá-Ios em número ilimitado (FURTADO, 1982, p. 4I- 
42)。

Daí devem ter surgido os primeiros conflitos envolvendo estes índios e "brancos": por um lado, na reação à invasão de seus territórios, que gradativamente foram sendo expropriados, cedendo lugar à monocultura açucareira; por outro lado, na reação à sua transformação en escravos. A princípio fugiram, mas a cada fuga tinham que fazer frente ao colono que ia buscá-los em seus refúgios. A contrapartida é dada pelos revides que promoveram, indo assaltar os estabelecimentos dos brancos (PRADO JR., 1982, p. 35)。

A fuga do centro de colonização açucareira no recôncavo baiano deve tê-los feito mìgrar em rumo oeste até os vales médios do Rio São Francisco. Aí, outra frente de expansão os encontrou, representada agora pela atividade criatória. Como se sabe, da Bahia a pecuária expande-se para o norte e o noroeste em direção ao Rio são Francisco, que é alcançado seu curso médio no correr do século XVII. Novamente viram estes índios Jê as suas terras serem ocupadas e serem "recrutados" como mão-de-obra para as fazendas de criação (PRADO JR。, 1982, x. 44-46; FURTADO, 1982, p. 59-60)。

Novamente iniciaram a fuga, indo ocupar a "Bacia do Tocantins, desde o sul de Goiás até o Maranhão, estendendo-se do Rio São Francisco ao Araguaia" (RIBEIRO, 1977, p。 65), no quadrante formado entre 0480 e 0510 meridiano e entre 0 120 e o I60 paralelo (GIACCARIA e HEIDE, 1972, ․ 14). Pela localização geográfica que passaram a ocupar,

".. pode-se seguramente dedu-
zir que muitas vezes tiveram
escaramugas com bandeirantes,
uma vez que seu habitat foi
mito percorrido por estes.


Mesmo depois de 1725, quando se iniciou o rovoarento, os primeiros arraiais que surgiram prćximos a Vila Boa, estavam dentro de seu território. $E$ enquanto novas expedições desciam o Tocantins vasculhando seus afluentes, estavam adentrando a área que lhes pertencia. (...) (RAVAGNAIII, $1978, \mathrm{p} .14$ )

Conforme já se nalisou anteriormente, para as capitanias onde a produção açuçreira não subsistiu ou para a população que não se dedicava à inástria açucareira, a captura dos "homens da terra",- sua escravização e comércio, acabou se transformando em importante atividade econômica (FURTADO, I982, p. 42). Este movimento, tendo como seu principal centro difusor a capitaria de São Vicente (São Paulo), promoveu ao longo dos séculos XVI e principalmente XVII e XVIII a desbravação e conquista de todo o planalto brasileiro.

As primeiras informações documentadas sobre os Xavante, aparecem durante o governo de D. João Manoel de Mello (1759 a 1770). Em carta de 29 de dezembro de 1762, este governador informava o que segue:

"Também dou parte a V. Ex. que - Gentio Xavante como menos bárbaro, não vive do corso pelo que nunca invadio as roças do Arrayaes de Crixas, Thezouras e Morrinhos que ficão nas suas vezinhanças: mas ha tres mezes a esta parte que contra o seu antigo costume, entrou com hum grande corpo de 
gente pelo nosso território fazendo mortes, e destruições suppondo que sugerido por indios que the mandarão os Jezuitas das Missões de Hespanha ...., se não acudissem logo à defesa dos mineiros de Crixás ... e sahindo com elles armados the impedirão a invazão retirarão-se os Xavantes; mas dentro em poucos dias tornarão a acometter as roças com maior numero de gentios, e muitos d'elles armados com espingardas." (Apud RAVAGNANI, I978, p. $14-15)$.

Os habitantes da região pediram soccrro ao governador que os autorizou a formar uma bandeira, chefiada pelo capitão-mor de conquista João de Godoy da Silveira e composta por mais de quinhentos homens. Em carta deste governador às autoridades metropolitanas, informavam-se quais os resultados que se esperavam desta bandeira:

"Destas bandeiras rezultão dous bens a este Continente, o primeiro castigar-se o Caya-pó, Xacriabá, e Acruá ... e ficar escarmentado o Xavante

..., o segundo . utilizamo-nos d'algum descoberto de boa conta que certamente o ha-de 'haver por aquelles destrictos, que não estão explorados por causa dos Gentios. Ha dez annos que não tem havicio hum descoberto ncvo, que augnente esta Capitania, só tem apparecido humas faisqueiras, que não dão lucro aos mineiros de que rezulta estarem pobres, endividados e experimentar diminuição o quinto" - ( Idem, p. 


$$
\text { 15)。 }
$$

Dois anos mais tarde: este mesmo governador voltou a fazer as mesmas observações, em carta de 7 de junho de 1764, para o Secretário de Estado Francisco Xavier de Mendonça Furtado. Acresce, porém, que:

".. convoquei huma junta em que se assentou com uniformidade de votos, que se the fizesse a guerra offenciva quando não se sujeitasse a abraçar a Religião Católica, e a ser subjeito a Sua Magestade. Os moradores de Pilar unidos com os de Crixás estão armados à sua custa, com licença minha, huma Bandeira de duzentos homens para hirem buscar aos seus alojamentos, espero que allem de se castigarem as inau ditas crueldades que estes novos inimigos executarão nas nossas terras, se descubra ras suas algusnas minas..." ( $I d e m$, p. 16)。

Um ano depois, o governador, enviou uma terceira carta, endereçada ao mesmo secretário, em 30 de março de 1765, na qual além de reiterar o conteúdo das anteriores, informou que os Xavante atacaram uma roça e que, ao se depararem com escravos negros, encheram-nos de agrados e asseguraram que todo negro que procurasse abrigo em suas aldeias acharia guarida. Diante destas "afrontas", a bandeira partiu

(RAVAGNANI, 1978, p. 17).

Diante destes relatos, duas questões básicas precisam ser analisadas: quais as condições econômicas e sociais em que tais situaçc̃es ocorrem? Como explicar a posição do governador em relação à Política Indigenista preconizada pela 
metrópole?

Após o início da ocupação de Goiás, que se da a partir de 1725, têm-se três décadas de grande efervescência em toda a região: a notícia do ouro atraiu para a região uma grande popuzação mineira, que em pouco tempo estava explorando toda a região do Tocantins e seus afluentes e dos formadores do Araguaia; esta populaçॄ̃o se alojou em pequenos povoados, dando surgimento a uma grande quantidade de arraiais. Nialsrado a legislação protecionista que proibia a escravização e propugnava pelos direitos e liberdades inzígenas, para os índios mesmo a situação pouco se alterou: em lugar de serem o alvo predileto das bandeiras para serem eliminados e os sobreviventes transformados em escravos, agora passam a ser considerados intrusos e, ao mesmo tempo, empecilho ao desenvolvimento da região. Da mesma forma, tinham que ser eliminados ou expulsos da área.

Nada mais restava às populações indígenas que ou permaneciam em suas terras e enfrentavam a perseguição, ou buscavam refúgio no interior ainda não atingido pela "febre do ouro"。

A partir de então, por volta de 1753, começou a decadência: as buscas de novos veios auríferos tornaram-se infrutíferas. A administração colonial iniciou uma busca intensiva de novas minas e passou a organizar e financiar bandeiras que partiam em todas as direções - sem, porém, nenhum outro resultado significativo. Evidentemente que as buscas acabaram por atingir as regiões onde os nativos haviam buscado refúgio e outra não foi a consequência senão aumentarem significativamente o número de conflitos. Estava, pois, declarada novamente a guerra ao índio. 
Não obstante toda a legislação protecionista, que porém deixa algumas brechas ("punį̧ão" em casos de ataque "guerr£ ofensiva"), o governador levando em conta as gradativas reducões do "quinto" à metrópole, precisava justificar para Portugal a invasão das novas terras e os conflitos com as tribos á localizadas. Uma vez caracterizados os índios de "agressivos", estava justificada e legalizada a "guerra ofensiva"。

Do ponto de vista dos índios, o que estavam fazendo era simplesmente auto-defesa; porém, do oficial, caracterizava-se uma agressão. A situação era, pois, altamente vantajosa para o governo e para os mineiros. Para os Xavante, um povo fundamentalmente caçador, vendo seu habitat muito reduzido, o conflito ou a submissão constituiam as únicas alternativas。

Como já se historiou anteriormente, 1772 marcou o início do governo de D. José de Vasconcellos, que assumiu num momento de agravamento da situação econômica. Da metrópole chegavam novas e terminantes instruções quanto ao tratamento com as populações indígenas: em lugar da política de perseguição, deveria ser adotado um tratamento brando, de pacificação e aldeamento. Porém, a atividade indigenista na província era outra: os contínuos ataques dos Xavante, Acroá, Carcabás e Kayaṕ aos arraiais mais próximos de seus respectivos territórios tribais, a prática arraigada de respondê-los com a "guerra defensiva", a legislação anterior ainda não revogada, etc。, deixavam o governador D. J•sé de Vasconcellos sem os meios necessários para se impor.

o que os documentos ristóricos demonstram, porém, é que o governador soube interpretar as novas diretrizes me- 
tropolitanas, por um lado não se descuidando dos atrativos da mineração, organizando várias expedições a partir de 1774 e por outro lado, dando nova orientação em relação aos silvícolas: de se buscar a amizade e o aldeamento.

Ouro, como se viu, não foi encontradc, mas milhares de índios foram subjugados e aldeados. Os antigos aldeamentos foram reformados e povoadcs: O resulamento militar imposto aos aldeamentos em governos anteriores foi substituidc por outro de inspiração mais "liberal"。Como bem assinalou ALANCASTRE (1864, p. 247 e s.), o alcance desta política era grande pois transformava os índios em "vassalos úteis", facilitandc o comércio terrestre e fluvial entre arraiais e províncias, aumentava a mão-de-obra disponível para a agricultura e como remadores habilidosos. Isto leva a concluir que a atividade indigenista muda, porém, sua essência continua a mesma: expropriação das terras indígenas, transformação de seus hábitos e gradativa incorporação como força de trabalho disponível e barata.

Muda o goverro goiano com a subida de D. Maria I ao trono português. Ascende no governo provincial D. Iuiz da Cunha Menezes que continuou na província o trabalho de seu antecessor: buscou reativar a mineração, mas face aos fracassos passou a se dedicar à "pacificação" e aldeamentos dos indígenas. Logo logrou a grande vitória de pacificar os Kayapó, que vinham criando grandes dificuldades à economia e ao povoamento da província, ercaminhando-os para a Aldeia D。 Maria I.

Este feito animou os habitantes do norte da província de insistirem na necessidade de pacificação dos Xavante, tal as dificuldades que estes índios criavam para os sertanejos, conforme os registros: 


\begin{abstract}
"Os povos do norte, excessivamente flagelados, pintaram com as mais tristes côres a precária condição a que estes barbaros... os reduziram。 A maior parte d'estes estabelecimento ruraes situados à margem dos rios estavam abandonados e estrazados. Era tamanha a devastação que não havia generos de primeira necessidade, e gado sufficiente para supprir o consumo da população / Ao passo que os Chavante de terra chegavam com suas carrerias às portas dos arraiaes, os de canôa praticavam toda a sorte de pirataria nos rios e suas margens." (... AIANCA grifo é nosso)。
\end{abstract}

O governador convenceu-se da necessidade de promover a pacificação deste grupo tribal (15), ordenando o início dos preparativos para a conquista. Porém, quando estava para iniciar os trabalhos, morreu o capitão que chefiaria a bandeira (ALANCASTRE, 1864, p. 320), não conseguindo que se alcançasse este objetivo durante sua gestão.

Seu sucessor foi seu irmão, Tristão da Cunha, que continuou os trabalhos de conquista dos índios, sendo que as vitórias conseguidas - com os Acroá, Kayapó, Javaé, Karajá, e

(I5) O registro de AIANCASTRE classifica os Xavante em de terra e de canôa, sendo esta problemática, pois esta tribo é eminentemente caçadora, desconhecendo embarcação. Para RAVAGNANI ( $1978, \mathrm{p} .60-61$ ), duas hipóteses existem para explicar esta situação: ou os documentos fazem confusão entre os Xavante e os Canoeiro, já que habitaram regiões contíguas no centro de Goiás, ou os Xavante haviam aprendido a utilizar a canoa com outras tribos ou sertanejos. 
outros - animaram o governador a partir para a pacificação dos Xavante, tidos na categoria dos "não civilizáveis" (MOREIRA INETO, 1971, p. 198). Iniciaram a organização da bandeira para tal fim, quando chega a notícia de que os Xavante haviam atacado o arraial de Crixás. A notícia apressou a saída da bandeira, e com ela tem início a "primeira pacificação dos Xavante, que ocorre entre 1784 e 1788 , durante o governo de Tristão da Cunha. O comando da expedição foi confiado a José Rodrigues Freire que, por causa de uma queda de cavalo, deixou o comando ao alferes Miguel de Arruda e Sá. A expedição contava com 98 soldados, vários intérpretes e um grupo de Caiapó, da aldeia de São José de Mossamedes (GIACCARIA e HEIDE, 1972, p。I7)。o relato da pacificação dos Xavante, da entrega cerimonial da Aldeia de Pedro III ou Carretão para o grupo pacificado e o juramento que o líder Xavante foi obrigado a fazer encontram-se transcritos no final deste trabalho (ver Apêndice 3).

Conforme se pode inferir pelo que já foi analisado anteriormente, a pacificação dos Xavante ocorreu num momento em que a situação econômica da Províncía era de rápida decadência e de redefinição da estrutura econômica, através do comércio com as Províncias do Pará e Maranhão e de uma rápida e crescente ruralização da produção。 É neste quadro em que são aldeados estes índios no Carretão。

Esta redụão possuía, de um lado do rio Carretão, um engenho de açúcar, moinho de milho, e as moradas do administrador e dos soldados; do outro lado do rio, as barracas de barro, com cobertura de mato, dos índios (POHI, apud RAVAGNAIII 1978, ‥ 72).

Porém, pouco tempo durou esta estrutura criada no 
Carretão, posto que a decadência econômica arrastou consigo a política indigenista zuté então adotada. Aos poucos, à redução foram se trainferindo (ou sendo transferidos) aventureiros e mineiros, além da transferência de aldeias Kayapó e Karajá, ferrenhos inimigos dos Xavante. Consta, ainda que imprecisamente, que este aldeamento tenha atingido cinco mil índios em seu período de aposeu (RATAGNaNI, 1978, p.72)。

Dado ao tratamento a que foram submetidos, aos maus tratos, à fome e ̀̀s inúmeras moléstias que acabaram contraindo no contato (GIACCARIA e HEIDE, 1972, p. 22), voltaram gradativamente a sua vida de refúgio, longe dos brancos (RIBEIRO, 1977, p. 65; GIACCARIA e HEIDE, 1972, p. 22; RAVAGNANI, $1978, p .74)$. Este retorno ao habitat original fica caracterizado pelo fato de em 1819, o viajante POHI ter encontrado no Carretão apenas duzentos e vinte e sete índios (Apud RAVAGNANI 1978, p. 74); e cinco anos depois CUNHA RATOS ter encontrado somente cento e noventa e nove habitantes (Apud RAVAGNANI, ' 1978, p. 75). Este decréscimo foi sendo observado por outros viajantes, até que "todos" os setenta silvícolas restantes foram transferidos para o rio São Patrício (Idem, p. 76)。 
4. A ECONONIA INERCANTII-ESCRAVISTA NACIONAL

o presente capítulo trata, em linhas gerais, da economia mercantil-escravista nacional em termos teóricos, estruturais e históricos. Primeiramente, buscar-se-á entender a problemática da passagem da economia colonial à economia mercantil-escravista nacional. Fm seguida, será analisada a forma histórica que assumiu a passagem da economia colonial para a economia mercantil-escravista no Brasil, entendendo-se que a superação da crise colonial no Brasil não significava somente a conformação da nacionalidade, mas principalmente que se encontrassem formas que reintegrassem o Brasil nas linhas de expansão do comércio internacional, posto que esta era a única saída para um país sem técnica própria e sem condições de acumular capital que pudesse ser desviado para novas atividades, - que se deu pelo nascimento da economia mercantil-escravista cafeeira nacional, que marcou simultâneamente a revitalização do caráter mercantil e o revigoramento da escravidão. Após, analisar-se-á a dinâmica das condições internas e externas que geraram e possibilitaram o desenvolvimento e a crise da economia mercantil-escravista cafeeira nacional. No quarto tópico será tratada a crise da economia mercantil-escravista, promo- 
vida basicamente pelo bloqueio ao desenvolvimento econômico nacional representado pelo trabalho escravo, destacando-se, po róm, que não basta a análise da transformação do trabalho cativo em trabaiho assalariado, se não for tratada a transformação das relações de produção em sua conexão e dependência ao đẹ senvolvimento das forças produtivas. Finalmente, se caracterizará os desdobramentos que a expansão da capacidade produtiva da economia mercantil-escravista cafeeira provocou。 Embora não haja a menor dúvida de que o setor econômico mais dinâmico e: por isso mesmo dominante, seja representado pela economia cafeeira, não seriam atingidos os objetivos deste trabalho se não se tratassem, ainda que suscintamente, das outras economias regionais do país: a economia amazônica, a economia regional do nordeste e a economia do extremo sul.

\subsection{Caracterização Geral da Passagem da Economia Colonial à Economia Nercantil-Escravista}

Conforme ficou evidenciado anteriormente, no desenvolvimento do modo de produção capitalista, o capitalismo industrial ofuscava cada vez mais o capitalismo comercial, assumindo o domínio da economia européia no final do século XVIII. Nestas condições de domínio do modo especificamente capitalista de produção, a economia colonial e a capitalista passavam a guardar entre si uma relação marcada por profundas contradições.

Para o capital industrial, as condições que asseguravam uma plena acumulação de capital durante a fase mercantil (monopólio comercial, prodụão de rrodutos agrícolas coloniais e/ou metais e pedras preciosas, trabalho escravo, etco), 
já não mais interessavam As condicões rara que a acumulacão de capital se realizasse rão rais precisavam de apoios externos, mas rassaram a se dar a đora no interior da própria estrutura eccnômica capitalista. Por isso mesmo, capitalismo indistrial e monopólio comercial passaram a Euardar profundas contradições, onde a destruição completa dos monopólios passou a ser condição necessária ao pieno desenvolvimento do próprio capital (PRADO JR., 1982, p. 124).

Analisando a questão de forma mais sistematizada, VIELIO (1975, p. 36-37) evidencia que foram pelo menos quatro as formas que caracterizaram a contradição entre o capitalismo industrial e a produção colonial:

1. o capital industrial passa a requerer não mais produtos agrícolas coloniais ou metais e pedras preciosas, mas a produção em massa, pelo conjunto de uma economia periférica, de produtos primários de exportação (alimentos e matérias-primas) a preços baixos; porque, enquanto produção mercantil complementar, si ̋nificaria rebaixar os custos da reprodução da força de trabalho e baratear o custo dos elementos componentes do capital constante;

2. o capital industrial passa a exigir da periferia a mercantilização da força de trabalho, postc que scmente o trabaino assalariado poderia significar, simultaneamente, mercados os mais amplos possíveis e produção complementar em massa - condições inatingíveis com trabalro compulsório;

3. o capital industrial almeja a subordinação do capital comercial às suas condições de acumulação de tal forma que capital industrial e capital comercial representem faces de uma mesma moeda (o capitalismo industrial), o que só seria possí- 
vel com a remoção do "monopólio do comércio colonial" e a transformagão destas sociedades em naçöes nas quais se pudesse apropriar diretamente do trabalho excedente - isto é, transîr mar as antigas colônias em economias periféricas, subordinadas às economias mais desenvolviaas e hegemônicas;

4. finalmente, somente a liquidaço do "exclusivo metropolitano" Earantiria que se produzisse livre de restriçöes e de preços fixados monopolisticamente.

Por tcdas estas circunstâncias, os impérios coloniais, fundados no monopólio, achavam-se irremediavelmente condenados. Na América Latina, consequentemente no Brasil, 은 capitalismo, em sua fase concorrencial ov competitiva, deu inźcio à crise das economias coloniais. A crise colonial significou concretamente a ruptura do "pacto colonial" e a constituição dos Estados Nacionaiș; porém, esta ruptura não causou de imediato a destruição do fundamento último das economias aqui implantadas - o trabalho compulsório, pois este pelo menos inicialmente, não afetava a entrada de produtos industriais ing̨leses e a transformação em trabalho livre era uma decisão nacional.

Quando em fins do século XVIII os conflitos internacionais se agravaram, arrastando consigo as monarquias ibéricas, estas não resistiram ao choque e todo o sistema colonial se desagregou. Para o murdo em geral, significava uma nova ordem sob o domínio e controle do capital industrial; para as colônias, significava a "independência", pelo menos em relação às suas respectivas metrópoles, e uma abertura de seus mercados ao comércio internacional (PRADO JR., 1982, D. I25)。

Concomitantemente a estas forças exteriores e gerais que condicionavam a "libertação" das colônias, outras for 
ças internas thes vieram ao encontro: as metrópoles

tinham chegado ao limite de sua capacidade realizadora e colonizadora; agora não passavam de simples parasitas de suas colônias. o parel que desempenhavam na economia era o de. simples intermediário imposto e parasitário: não eram nem consumidoras apre ciáveis dos produtos coloniais que se destinavam a outros mercados, nem fornecedoras dos artigos mais ccnsumidos nas colônias. (Idem, p。125).

Foram circunstâncias internacionais, porém, que fizeram com que este sistema de restrições caísse por terra, a começar pelo monopólio do ccmércio externo que foi abolido em virtude de circunstâncias quase fortuitas; porém, iniciada a desagregação, toda a estrutura que vinha de três séculos de formação colonial seria abalada, exigindo-se a reorganização interna de cada uma das colônias (PRADO JR., 1982, p. 126).

Em síntese, se no primeiro momento as formações sociais escravistas do Novo Mundo foram determinadas pela reprodução do capital mercantil; no segundc momento, a partir do século KVIII, passam a ser decididamente determinadas pelas exigências de reprodução dc capital industrial (IANNI, in IAPA, $1980, \mathrm{p} .162$ ).

Da forma como se tem analisado, a crise do sistema colonial resultava, portanto, numa multiplicidade de situações profundamente dinâmicas e coladas às transformações que ocorriam a um nível mais amplo da extrutura econômica internacional (das transformações no interior mesmo do modo de produção capitalista). Primeiramente, o pleno deservolvimento do capital industrial impunira a subordinação do capital comercial às condições de acumulação da eccnomia capitalista, onde o 
mercado deixa de ex a base rarà a Eeraçãc e apropriaçãc dos lucros e passa a ser um ̇nstrumento de mediatizaçãc entre a produç̃o e o consumo (ver MARX, 1980, Iivro 3, Vol. 4, p. 337 e s.). Esta subordinação do capital comercial ao capital industrial só seria possível se o mercadc internacional fosse livre, isto é, não estivesse submetido às condições de monopólio comercial. Neste aspecto, a crise do sistema colonial significou concretamente a ruptura do "pacto comercial" e a conformação de Estados nacionais nas regiões até então submetidas à relação metrópole-colônia (NELIo, 1975, p.36-37; PRADO JR。, 1982, p. 125).

A liquidação do "exclusivo metropolitano" garantia a livre produção e comercialização, o que significava, para o capital, a possibilidade de apropriação direta do trabaIho excedente em escala interracional. Desta forma, o capital industrial nada mais fez que transformar as antigas economias coloniais em economias periféricas, subordinadas às condições impostas pelas economias mais desenvclvidas (NELLO, 1975, p. 36-37). Sobre isto, é necessário que se entenda que esta fase de transição do capi talismo nas recém formadas nações se realiza quändo o capitalismo já é dominante em escala mundial. A dominação das relações capitalistas em âmbito mundial, supõe, por sua vez, um desenvolvimento anterior do modo de produção capitalista e, particularmente, a sua existência sob formas já bastante avançadas de um mercado mundial. É, por isso, que no processo de desenvolvimento do modo de produção capitalista a dominação das relações de produção capitalistas significa gue a reprodiçãa ampliada do capital não se realize mais somente ao nível nacional, mas em âmbito internacional. Desta forma, o capital industrial submete as próprias condiçoes de desenvol- 
vimento de cada eccnomia nacional; ou seja, a reprodução do capital em escala nacional passa a ser submetida às condições de reprodução internacional do capital (\$ILVA, 1980, p.24-25).

Quardo se afirma que o capital industrial nada meis fez que transformar as colônias er economias periféricas, - significa refletir as próprias condições contraditórias da dominação e reprodução das relações capitalistas em escala mundial. Como bem observa wIIVA (1980, p。27), as relações econômicas capitalistas mundiais dependem da posição ocupada por cada nação no seio da economia mundial, encuanto formes especificas de reproduçãc do capital. Isto equivale a dizer que no seio da economia mundial, "... as diferentes economias nacionais são liģadas por relações de subordinação-dominação. • " (SIIVA, 1980, p. 27 - o grifo é nosso).

Outra característica da contradição que passou a existir enire o capitalismo industrial e as economias coloniais é que estas acabam afetadas em sua própria estrutura produtiva. Tal situação ocorria na medida em que o capital industrial não mais requeria produtos agrícolas coloniais ou metais nobres e pedras preciosas, mas que o conjunto da periferia passasse à produção em massa de produtos primários de exportaçãc - alimentos e matérias-primas。 Isto significou o alargamerto da divisão social do trabelho, que do interior de uma mesma estrutura produtiva, passou a afetar a própria estrutura econômica em escala mundials de tal forma que a posição das nações nc âmbito internacional, além da suborainação à nível de mercado, fosse determinada por sua posição na estrutura produtiva - isto é, encuanto produção complementar destinada a rebaixar os custos com o capital variável (reduzindo - valor necessário à reprodução da fcrça de trabalho) e bara- 
tear o custo dos elementos componentes do capital constante, como observou NEIIO (1975, x. 36-37).

Conforme já foi referido, ainda que inicialmente estas rupturas não tenram causado a destruição imediata do trabalho compulsório, na meōida em que o capitalismo industrial se impõe como dominante e hegemônico, passa a exigir da periferia a destruição das relações de trabalho escravista. o exame detido da questão leva a concluir que a eliminação do trabalho comrulsório se impunha duplamente: por um lado, porque para o desenvolvimento capitalista a existência do trabaIho escravo: coexistindo com o trabalho livre, representava uma contradição estrutural que colocava limites ao próprio dese:vvolvimento do capitalismo; por outro lado, porque o desenvolvimento capitalista significa que, necessariamente, 0 desenvolvimerto das forças produtivas passa a exigir relações de trabalho que lhes sejam adequadas. Impunha-se, em qualquer circunstância o reforço da dominação do capital sobre o trabalho. o primeiro aspecto da questão é posto de forma clara por IANNI ao estabelecer que a existência do trabalho escravo representava um paradoxo quando.se pensa na articulação e coexistência do trabalho livre na Europa e a escravidão nas Américas e Antilhas. Ao mesmo tempo, revela-se numa contradição estrutural quando da independência das colônias (IANNI, in IAPA, 1980, p.164). Assim, na medida em que ocorre - desenvolvimento do capitalismo em escala mundial, a destruição das relações sociais e técnicas de produção que não se adequavam ao ritmo e sentido da acumulação capitalista se impõe aos recém criados Estados nacionais e o trabalho livre é implantado em conformidade com as condiçoes próprias de cada país (Idem, p. I64-165).

Do ponto de vista do desenvolvimento do capita- 
lismo, é necessário se considerar, artes de mais nada, que o desenvolvimento das forças produtivas necessariamente toma as formas adaxtadas à reprodução das relações de produção dominantes (SILVA, 1980, D. 20). Se o capitalismo industrial criou as situações geradoras da crise da economia colonial, logo apoś ele criará as condições para a reorganização das economias nacionais. NIELIO sintetiza estas condições em dois momentos:

"... de um lado, em 1846, com as Corn Iaws, estavam batidos os interesses protecionistas agrários; de outro, o deslocamento do foco de acumulação da indústria textil para a indústria de bens de produção.. (entre 1845/47 com a Gigantic Railway Mania), estimula em seguida, a exportação do capital, entendida como exportação de capital monetário e de bens de produção, mas, principalmen te, como "extensão" das relações sociais de produção capitalistas." (NELLO, 1975, p。 39).

Essa tendência geraI de desenvolvimento do capitalismo industrial, alcançado em sua forma mais avançada neste período somente pela Inglaterra, não teve o mesmo poder de difusão na América tuatina aue o alcançado em outros continentes. De modo geral, o fraco poder de difusão do capitalismo exercido sobre as nações latino-americanas não pode ser explicado, em última análise, pela ausência ou frouxidão da demanda externa, mas pelas dificuldades internas de organização de economias expcrtadoras Vigorosas (IVILO, I975, p. 40-4I). No Brasil, porém, diferentemente do conjunto das economias latino- 
-americanas, a penetração do capitalismo se deu de modo mais acentuado: cria uma demanda própria e a rassagem da economia colonial para a exportadcra caxitalista é possível graças à importação de capitais (Idem, p。4I).

Nestas condições, o capitalismo passa por novas transformações, arrastando ccnsigo as economias nacionais que são subordinadas ao seu movimento. Não se pode deixar de lado que o desenvclvimento do capitalismo a partir de meados do século XIX culminou com a emergẽncia do capitalismo monopolista - que começa a se delinear de forma clara com o processo de cartelização após a crise de 1873 e que se conformará completamente no início do século XX (ver LENIN, 1982, p. 16-29). A emergência do capitalismo em escala internacional provocará uma grande alteração nas relações econômicas mediatizadas pelo comércio mundial: já não se buscava mais a monopolização do mercado de mercadorias, mas a concorrência no mercado de capitais, com vistas a se promover o desenvolvimento do capitalismo, onde este era ainda muito fraco, ainda que este "desenvolvimento" estivesse vinculado a uma posterior absorção de mercadorias (NELLO, 1975, p. 42-43). Já não se tratava mais de estender cura e simplesmente a influência econômica e política nas relações entre os Estados industrializados e os "atrasados", mas de se ter o domínio completo de um Estado sobre o outro. Desta forma, as potências industriais passam a ter uma verdadeira corrida por anexaçoes territoriais que garantam a exclusividade de exportações de capitais (Idem, p. 43).

Conforme se disse acima, foi a mediatização do mercado mundial que criou as condições históricas para as transformações das relações econômicas internacionais no final 
do século XIX.

Em termos de melhor precisar esta passagem do capitalismo a uma "etapa superior" de seu desenvolvimento, em relação à etapa anterior - ou de capitalismo concorrencial é preciso considerar que enquanto o capitalismo concorrencial, se caracterizava pela exportação de mercadorial (o que é insuficiente para promover mudanças nas relações de produçäo), o capitalismo monopolista se caracteriza pelo papel dominante que passa a ser desempenhado pelas exportações de capitais (16) Se o capital é entendido enquarto uma relação social, ainda que possa assumir diferentes formas, a exportação de capitais necessariamente provoca um desenvolvimento das forças produtivas, mudando as relações de produção sob as quais são produzidas mercadorias, sendo que este passa a ser o espaço em que se dá a reprodução ampliada do próprio capital.

Visto de modo geral, este período de emergência do capitalismo monopolista, pode ser caracterizado pelos seguintes traços gerais: I) por um extraordinário proces\$o de acumulação, centrado, simultaneamente, numa aceleração no ritmo de incorporar o progresso técnico e no estabelecimento de uma nova tecnologia; 2) promoção, durante a "segunda revolução industrial", da monopolização dos principais" mercados industriais por empresas cada vez maiores; 3) este processo foi co-

(16) A importância das exportações de capitais no final do século XIX, limiar do XX, é destacada em toda sua clareza por LEMN ( $1982, p_{0} 60$ e s.), que entende que neste momento o capitalismo entra numa "etapa superior" de seu desenvolvimento, o "imperialismo". A conseqtêricia imediata da exportação de capitais é de que os "países exportadores de capitais partilham (em sentido figurado) o mundo entre si ..." (p.65). 
mandado pelo capital bancário, que também vai se monopolizando e que, mescla o ao capital industrial, conforma o capital financeiro; 4) rompimento do monopólio inglês, devido ao surgimento de outras potências industriais (tais como os Estados Unidos, Alemanha e Japão); 5) intensificação da exportação de capitais e da concorrência entre os diversos capitalismos financeiros; 6) surgimento do "colonialismo monopolista entre as principais potências que acabam por dividir o mundo (17).

\subsection{A Passager da Economia Colonial à Economia Mercantil-Escravista no Brasil}

A queda do exclusivo metropolitano e a formação a Wublo Nacional marcam no Brasil o início da crise da economia colonial.

A queda do "exclusivo metropolitano" deu-se, como se sabe, circunstancialmente e por força de condições exter-

(17) o processo histórico de transformação do modo de produção capitalista de sua fase concorrencial para a monopolista, bem como as características fundamentais do capitalismo monopolista, podem ser melhor entendidos a partir de IENIN (1982, p. 16-97), onde é tratada a problemática da monopolização e estabelecimento de novas bases técnicas (capítulo I); a redefinição da função dos bancos, sua monopolização e conformação do capital financeiro (capítulos II e III); a problemática envolvendo o mercado internacional e a passagem da exportação de mercadorias para a exportação de capitais (capítulo IV); o rompimento do monopólio inglês, a concorrência entre os diversos capitalismos financeiros e a redefinição das áreas de influência e novas formas de dependência (capítulos V, VI e VII)。 
nas: em 1807 os exércitos napoleônicos invadem Portugal como forma de forçá-lo ao bloqueio contra a Inglaterra; a corte portuguesa se transfere então para o Brasil, que se transforma, de um momento para o outro, em sede da monarquia portuguesa. A primeira providência do monarca português ao desembarcar em terras brasileiras - em 23 de janeiro de 1808 - e ainda na Bahia, onde fazia escala para o Rio de Janeiro, foi expedir uma carta régia abrindo os portos brasileiros a todas as "nações amigas". Estava, pois, franqueada a colônia ao comércio internacional.

Com a abertura dos portos, estava abolido o que havia de substancial na dominação metropolitana: o monopólio comercial. A grande beneficiária dessa medida foi a Inglaterra, o que fica patente face aos acordos firmados em 1810: um de "comércio e navegação" e outro de "amizade e aliança".

A permanência da corte se prolongou por treze anos (1808 a 1821). Além da libertação dos entraves do monopólio, outras medidas foram tomadas e que beneficiaram as atividades da então sede provisória da monarquia, tais como a revogação das leis que proibiam as manufaturas, a construção de estradas e melhoria dos portos, introdução de novas espécies vegetais e promoção de imigração de colonos europeus - fatores que contribuíram, de modo geral, para o desenvolvimento das forças produtivas e para as transformações nas relações de produção.

Com a volta da família real para Portugal ( 1821 ), - Brasil ficou sob administração regencial - do Príncipe Regente D. Pedro. A partir de então, os esforços portugueses em relação ao Brasil passam a ser de recolonização. Faltavam, po- 
rém, condições externas e internas para o restabelecimento do monopólio comercial: os interesses do capital internacional estavam em jog̃o, além dos da burguesia que já havia se consolidado nos territórios da colônia portuguesa em terras americanas. Assim, outra alternativa não restou a D. Pedro que, em 7 de setembro de 1822, decretar a independência de colôria em relação a sua metrópole, estabelecendo o Estado nacional brasileiro

Juntamente com estes fatos, e embora se conserve a estrutura anterior que marcou a formação e evolução colonial brasileira, entra-se num perícado diferente do anterior. Essa passagem não pode ser entendida, porém, como um progresso cumulativo, mas enquanto um processo profundamente contraditório

No plano econômico, a questão é muito complexa, pois enquanto a economia internacional vivia a . efervescência provocada pela revolução industrial - que marca o apogeu do capitalismo industrial em sua fase ccncorrencial - no Brasil a estagnação e a decadência não podiam ser camufladas.

A superação da crise não se daria se o Brasil não se reintegrasse nas linhas em expansão do comércio internacional:

"(...) Num país sem técnica própria e no qual praticamente não se formavam capitais que pudessem ser desviados para novas atividaāes, a única saída que oferecia o século XIX para o desenvolvimento era 0 comércio internacional o. " (FURTADO, 1982, p. 110)。

Eram, porém, remotas as possibilidades de que a recuperação se desse através das exportações tradicionais do 
Erasil, dada a tendência declinante dos preços desses produtos no mercado internacional. O mercado do açúcar se tornava cada vez menos promissor: na Europa, o açúcar de beterraba enraizara-se em interesses criados dentro dos tradicionais mercados importadores, além de sra produção ter-se desenvolvido sobremaneira na etapa das guerras napoleônicas; a Inglaterra continuava a ser abastecida por suas colônias antilhanas; os Estados Unidos, que constituiu um mercado importador em rápida expansão, era suprido por uma produção crescente da Iuisiânia; ademais, Cuba havia aberto seus portos a "todas as nações amigas", ainda como colônia espanhola, constituindo-se num novo mercado supridor de açúcar, notadamente aos norte-americanos. A situação do algodão era ainda pior que a do açúcar: ainda que o algodão tivesse se transfcrmado na principal matéria-prima do mercado internacional, os EUA iniciaram a produção em larga escala; com isso, os preços do produto se reduziram a menos de um terço e se mantiveram nesse nível; com esses preços, a rentabilidade do negócio algodoeiro era extremamente baixa no Brasil, não passando de um complemento da economia de subsistência para as regiões que o produziam. Os demais produtos de exportação brasileiros (como o couro, o arroz, cacau, etc.) não admitiam grandes possibilidades de expansão (FURTADO, 1982, p. 111-113)。

Era preciso, pois, encontrar produtos de exportação em cuja produção entrasse como fator básico a terra, já que era o único fator de predução abundante no país. Quanto aos demais elementos necessários à reorganização da estrutura produtiva, capitais praticamente não existiam e a força de trabalho era basicamente constitúa por um estoque de pouco mais de dois milhões de escravos, parte surbtancial dos quais 
permaneciam imobilizados na indústria açucareira ou prestando serviços domésticos (FURTADo, 1982, f. 113).

$$
\text { Como forma de superar a crise e em seu próprio }
$$

seio, nasceu a economia mercantil-cafeeira nacional. 0 nascimento deste novo período marca, simultaneamente, a revitalização do caráter mercantil e o revigoramento da escravidão, dentro, no entanto, dos quadros de uma economia controlada nacionalmente (MELIO, 1975, p.47).

Apesar da antigtlidade do café no país, introduzido no Brasil desde começo do século XVIII, a sua cultura não representou nada de significativo até os primeiros anos do século passado. Até então, o café, cultivado em toda parte, destinava-se mais ao consumo doméstico nas fazendas e propriedades em que era cultivado (PRADO JR., 1982, p. 159; FURTADO, 1982, p. 113). No último decênio do século XVIII, os preços se elevaram, fato causado pela desorganização da colônia francesa do Haiti, grande produtor deste gênero, expandindo a produção em várias partes da América e da Ásia. Essa expansão provocou um período de óscilações nos preços, com tendência a preços declinantes que se estende até os anos trinta e quarenta do sécuıo XIX, o que, entretanto, não deseneorajou os produtores brasileiros que encontravam no café uma oportunidade de sair da crise e utilizar os recursos produtivos semi-ociosos desde a decadência da mineração. o café transforma-se, assim, em produto de exportação (18) concentrando, inicialmente, sua pro-

(18) Embora não existam dados seguros das primeiras exportações de café brasileiro, alguns dados citados por PRADO JR。 (1982, p. 160) dão uma idéia da rapidez com que se desenvolveram: em 1779, exportou-se 79 arrobas; em 1806 foi de 82.245 arrobas; a partir de I82I a exporitação foi se acelerando, até atingir na década de 188.1-90 a exportação de 51.631 milhares de sacas。 
dução na região montanhosa próxima da capital (Rio de Janeiro) o início da produção do café como produto de exportação pôde se reaiziar ccm base no aproveitamento de recursos pré-existentes e sub-utilizados: a relativa abundância de mão-de-obra, conseqtência da desagregação da economia mineira; a proximidade do porto que permitia solucionar o problema do transporte pelo uso da mula como veículo de carga, etc. (FuRTADo, 1982, . p. $113-114)$.

Para que se possa compreender melhor a gênese da economia mercantil-escravista brasileira, é conveniente que se analisemos pilares sobre os quais se sustentou: 1) a origem do capital-dinheiro que a ela se destinou; 2) a existência e a mobilidade dos recursos produtivos (terra e mão-de-obra escrava); e 3) o nascimento e o sentido da demanda externa por café que the confere seu caráter mercantil.

o capital-dinheiro, utilizado no financiamento da economia mercantil-escravista nacional é fruto do capital mercantil nacional, que foi se formando durante a colônia, e ganhou impuiso com a queda do exclusivo metropolitano e com o surgimento de um embrionário sistema monetário nacional, ambos consequências da vinda da família real para o Brasil (NELLo, 1975, p. 47).

O significado e importância do setor mercantil na montagem do negócio cafeeiro é entendido mais profundamente quando é analisada a participação do "comissário" na organização cafeeira:

"O significado do comissário na organização do grande negócio do café rão se esgota em ter sido o pivot na comercia- 
lização. Articulado a este traco de sua atividade, aparece outro..: seus interesses que eram o de fazer passar por suas mãos a maior quantidade possível de café fizeram-no participar da montagem e custeio das fazendas, invadindo a própria área da producão, finarciando-o." (FRAIVCO, 1969, p. 169)

Poném, não se pode esquecer que colado à questão a origem do capital-dinheiro, que se destinou a gestar as condições da economia cafeeira, está também, como coloca FURTADo (1982, p. I14-116), a formação de uma nova clesse empresária que desempenhará o papel de vanguarda da expansão cafeeira. A origem desta classe de empresários está presa às condições de acumulação de capital herdadas das atividades comerciais coloniais (comércio de gêneros e de animais para o transporte, comércio de escravos e usura); na medida em que o café assumia importância comercial crescente, esses grupos de comerciantes locais e "comissários" passaram a se interessar pela produção. Além do capital-dinheiro necessário ao financiamento da economia mercantil-escravista nacional, outros recursos produtivos havia eque estavam sub-utilizados: 1) a existência de terras propícias ao café próximas ao Rio de Janeiro, mas que por serem objeto de propriedade ou posse recueriam cue houvesse capital para adquiri-las ou para as despesas com a validação da posse; 2) força de trabalho escrava, liberada pela desaøre cação da economia mineira, mas que por representarem capital ativo, possuíam um preço que tinha que ser coberto.

A questão da terra não constituiu, em momento alEur da implantação, problema de vilto, dada as Erandes re- 
servas de terras virgens e inexploradas com solos magníficos e todas as demais condiçôes exicidas pelo café. Seu ponto de partida foi a vizinhança próxima do litoral da região montanhosa que circundava a cidade do Rio de janeiro. Para o sul do Rio de janeiro, os cafezais acompanharam as encostas no litoral; na província de São Paulo, en Ubatuba, Caraguatatuba e São Sebastião, ocupando toda a região dc litoral norte. Este foi o início; de lá, a lavoura cafeeira se expandiu pelo vale do rio Paraíba, que se tornou grande centro condensador destas lavouras; a partir dessa região os cafezais invadem e ocupam largamente a parte oriental da província de são Pavio; em outra direção, estendeu-se pela região fronteiriça de Minas Gerais.

A problemática envolvendo a força de trabalho tem exigido maior profundidade na análise. Na etapa de implantação da cultura cafeeira, pôde-se contar com relativa abundância de mão-de-obra escrava em conseqtência da desagregação da economia mineira (FURTADO, 1982, p. 113-114). Na medida em que ocorria a expansão da economia cafeeira, no transcorrer da primeira metade do século XIX, a crescente procura de escravos na região cafeeira foi suprida graças à intensificação do tráfico interno, em prejuízo das regiões que já estavam operando com rentabilidade reduzida. Porém, quando foi eliminada a única fonte importante de imigração de força de trabalho cativa, que era a africana, a questão da mão-de-obra se agrava e passa a exigir urgente solução (Idem, p. 119).

Mias, o entendimento da.disponibilidade de recursos prévios, por si só, não permite compreender o complexo nascimento da economia cafeeira, já que nos fornece exclusivamente o lado da oferta. É preciso que se busque, também, o nasci- 
mento e consolidação da cultura cafeeira na demanda externa por café: no transcorrer do século XVIII o café adquire importârcia crescente nos mercados internacionais, constituindo-se no principal alimento de luxo nos países do ocidente, o que estimulou, como se viu, sua cultura nas colônias tropicais da América e Ásia. o Brasil ocupava, então, posição mito modesta, que se manterá relativamerte inalterada até o início do século XIX (PRADO JR., 1982, p. 159-160)。Foi a elevação dos preços ocorrida em final do século XVIII e início do XIX, em decorrên cia da desorganização da colônia frarcesa do Haiti, que estimulou seu cultivo, fazendo com que essa cultura passasse a ter importância comercial já no final do séc.XVIII。Porém, a expansão da produção em várias partés da América e da Asia, fez com que ocorresse a baixa de preços, que se estende pelos anos trinta e quarenta do século XIX (FURTADO, 1982, p. 113-114). Esta situação não provocou um recuo na oferta brasileira, posto que os produtores brasileiros encontravam no café uma oportunidade para utilizar recursos produtivos semi-ociosos desde a decadência da produção mineira (Idem, p. 114). Porém, do lado da procura, as mudanças foram significativas: o crescimento da oferta, que provocou a queda nos preços internacionais do café, fez com que deixasse de ser considerado produto colonjal, generalizando significativamente seu consumo. O aumento do consumo provocou a elevação dos preços, que estimulou novarnonte o crescimerto da oferta (NEIIO, 1975, p. 50).

É, pois, a própria expansão da oferta brasileira que permite a ampliação da demanda e, concomitantemente, estimula novamerte o crescimerto da oferta.

As similitudes entre a economia colonial e a eco- 
nomia mercantil-escravista cafeeira nacional são óbvias. Mas o quadro em que se deram é profunàmente diferente。 te de se concordar com os termos através dos quais NIELIo enterlde a empresa cafeeira, como latifúndio e escravista:

"(...) Como latifúndio não somente porque existisse uma determinada repartição de terras prévia à sua constituição. sur ge como latifúndio também $\epsilon$, principalmente, porque dados os preços dos recursos produtivos e se definindo a produção cada vez mais como produção em massa, as margens de lucro eram reduzidas o que impunha uma escala mínima de produção lucrativa e, reversivamente, determinava investimentos viltosos... como latifúndio escravista, não somente porque escravos estivessem disponíveis. Surge como latifúndio escravista também e principalmente porque, tendo em vista, novamente, o caráter da demanda externa e o investimento exigido, o trabalho escravo, siper-explorado, mostrou-se mais rertáveI。 ... não porque... o capital demonstrasse qualquer vocação escravista. (mas porque)... a taxa de salário dever-se-ia fixar em níveis elevados, pois haveria de compensar aos olhos dos produtores a alternativa de produzirem sua própria subsistência, como pos seiros ou pequenos proprietários. (..)" (NELIO, 1975, p. 5I).

Foi no momento em que a economia cafeeira ganhava seus contornos, por volta de 1830, e quando o Brasil já era o 
primeiro produton mundial, que a economia mercantil-escravista assumiu seus traços característicos: grande empresa, produzindo em massa, apoiada no trabalho escravo, articulada a um sistema comercial-financeiro, com controle nacional da produção e do comércio (NELIO, 1975, p. 52).

4.3. A Economia Mercantil-Escravista Cafeeira Nacional

A conformação da economia mercantil-escravista brasileira foi a forma como se superou no Brasil a crise eccnômica que acompanhou o rompimento do monopólio comercial e o fim dc estatuto colonial. Para entender profundamente a economia mercantil-escravista cafeeira nacional é necessário analisar a dinâmica das condições internas e externas que a geraram e possibilitaram seu desenvolvimento e crise.

Conforme já se eviderciou anteriormerte, a crise das economias coloniais e sua superação se deu colada às transformações econômicas internacionais, quando as condições de reprodução do capital industrial passaram a exigir a submissão do capital comercial, ao mesmo tempo em que esta reprodução rão se realizaria mais somente em âmbito nacional, mas passava a ser submetida às condições de reprodução internacional do capital. As economias nacionais sofreram, ertão, um impacto face a todas as transformações ocorridas, criando condições ao seu desenvolvimento.

No que se refere ao Brasil e, em particular, ¿̀ economia cafeeira, essas condições foram sobremaneira favoráveis. O aparecimento dos navios a vapor no Atlânticc sul deu 
um novo impulso ao comércio de longas distâncias e, em particular, veio favorecer as relacões comerciais do Brasil com a Europa e Estados Unidos. For outro lado, a ampliação do comércio internacional do café, estagnada ou em baixa desde a época da independência (década de 1820), apresentou-se em alta, criando as condições para inversões (SIIVA, 1980, p。29).

É imprescindíveI que se destaque, porém, que já não mais se tratava do simples comércio interracional de mercadorias, que por si só seria incapaz de promover as transformaşões da estrutura econômica dos países onde o desenvolvimento do capitalismo ainda era muito fraco; trata-se, principalmente a partir da segunda metade do século XIX, de exportações de capitais (Idem, .29-33). Nesse sentido, não é possível explicar o desenvolvimento do capitalismo no Brasil se não se consiaerar o papel fundamertal desempenhado pelos empréstimos externos (Idem, p. 34).

Isto significa dizer que o desenvolvimento

da economia mercantil-escravista nacional foi determinado historicamerte pelo papel dominante que passa a ser exercido pelas exportações de capitais. Considerando o capital como relação social, ir-se-á entender o desenvolvimento das forças produtivas e as mudarịas nas relações de prodụ̧̃o sob as quais é produzida a mercadoria café.

Se o capitalismo internacional possibilitou

as condições para o desenvolvimento econômico nacional, por outro ladc, ele criou novas condições para que ocorresse sua reprodução ampliada. ou seja, as relaşões econômicas sob a dominação do capital passaram a depender da posição ocupada por cada nação no mercado mundial - posição de dominação ou de subordinação. Através destas relações de dominação e de suboridinação, 
o capital passou a ser reproduzido. Ijesse seritido, as economias internacionais dominantes, ao exportarem os capitais nenecessários ao "deservolvimento" das economias nacionais "airasadas", provocaram mudança nas suas estruturas produtivas desenvolvendo suas forças produtivas e trarsformando suas relações sociais de produção, porém com vistas a que o conjunto das periferias passasse à produção eni messa de produtos primários de exportação, destinados a rebaixar os custos com o capital variável e com os elementos componentes com o capital constante. o antigo "monopólio comercial" foi substituido, portanto, por uma nova forma de sủordinação ao próprio capital.

t, por isso, que não se pode explicar o desenvolvimento cafeeiro por ele mesmo, posto que a exportação-importa ção de capitais é condição essencial para criar as condições de seu desenvolvimento: o financiamento da produção, a tran $S^{-}$ formação de suas bases técnicas, a ampliação da demanda por café no mercado mundial e até mesmo para reorganizá-Io em termos de mercado de trabalho.

Concomitantemente às transformações que ocorriam no âmbito da economia mundial, internamente, o fim do "monopólio comercial" e o "fim do estatuto colonial" - fatos que ocorreram, como se viu, com a vinda da família real ao Brasil, em 1808, e com a proclamação da Independência, em 1822 - determinaram o acesso dos comerciantes brasileiros ao grande comércio de importação-exportação. Com isto, a burguesia comercial brasileira desenvolveu-se rapidamente, graças sobretudo à consolidação e expansão do café, que essa burguesia organizou juntamente com a aristocracia fundiária local (SIIVA, 1980, p. 39-40)。

Inicialmerte, a economia cafeeira reforçou a 
. .106 。

estrutura tradicional da economia brasileira: produção intersiva e en messa de produtos destinados à exportação, a grande propriedade monocultural e o escravismo (PRADO JR., 1982, p. 165-167; reLIO, 1975, p. 51-52); porém, na medida em que a economia mercantil-escravista cafeeira vai se consolidando e garihando seus contornos, as suas contradiços - representadas principalmente pelo trabalho escravo - vão afiorando, exigindo transformações qualitativas na estrutura produtiva.

É, por isso mesmo, que o seu processo de desenvolvimento significou também o processo de desenvolvimento das forças produtivas, com melhoria das bases técnicas da produção; transformąão das relações sociais de produção; diversificação da atividade produtiva, com a organização da produção agrícola de alimentos; surgimento de uma série de outras atividades afins (bancos, escritórios, armazéns, comércio atacadista e de importação-exportação, do aparelho de Estado etc.); além do desenvolvimento da indústria de produtos manufaturados (CANO, 1981, p. 58 e s.).

Sob a dinâmica dessas condições internas e externas, a produçãa e exportação cafeeira cresceu muito rapidamente durante todo o século XIX (Ver SILVA, 1980, p. 49; PRADO JR., 1982, p. 160).

o desenvolvimerto da economia cafeeira é inegável, transformando o complexo econômico cafeeiro, ao longo do século XIX e mesmo nas décadas iniciais do século $\mathbb{X X}$, na ativiaaade econômica dominante, a ponto de assim considerá-la SII$\mathrm{VA}$ :

"A partir da década de 1870, e sobretudo a vartir de 1880, quando a médie anual uI- 
trapassa os 5 milhões de sacas por ano, o café torna-se o centro motor do desenvolvimerto do caritalismo no Brasil." (WIIVA, $1980, \mathrm{p} .49$ ).

o crescimento da produção é acompanhado por un desiocamento do centro das plantaç̃es, até o momento em que, na década de 1880, a xrodução de São Paulo ultrapassa a produção das "antigas regiões", principalmente representedas pelo Rio de Janeiro, chegando mesmo a substituir o vale do Paraíba (19).

Com base nas linhas gerais do processo histórico da cafeicultura mercantil-escravista, é possível que se retcmem, de forma sistemática, os principais elementos componentes que caracterizam as condiçoes fundamentais deste período histórico: 1) a disponibilidade de força de trabalho; 2) a disponibilidade de terra; 3) a demanda dos mercados externos; 4) o financiamento da produção e o capital cafeeiro; 5) o desenvolvimentc tecnológico e das forças produtivas em geral.

o principal elemento da estrutura produtiva da economia cafeeira foi a disponibilidade de força de trabalho cativo. Esse elemento era o mais problemático já que estava vinculado à necessidade de suprimento de escravos a baixo cus-

(19) Este deslocamento da produção do Rio de Janeiro e Vale do Paraíba é analisado por SILVA (1980, p. 49-50), apoiando-se nos dados das exportações pelos portos do Rio de Janeiro e de Santos: em 1852-1857 Santos escoa $6 \%$ da produção nacional, enquanto o Rio de Janeiro exporta $92 \%$; em 1867-1872 o pcrto do Rio de Janeiro escoa ainda 81 \% da produção, "...mas a partir da década de 1870, a Província de são Paulo é de longe o princípal responsável pela exportação cafeeira. ( ...)" ( $p$. 50)。 
to. Inicialmente, a mão-de-obra escrava da economia cafeeira foi suprida pela disponibilidade de escravos resultante da decadência da economia mineira. Esgotadas as possibilidades de transferência, foi o tráfico externo que, sem dúvida, constituiu a principal fonte de escravos para as fazendas de café; ademais, a imigração externa de escravos era importante porque a população escrava interna, em virtude das péssimas condições de vida e trabalho, decrescia (SILVA, 1980, p.40). A força de trabalho da economia brasileira estava constituída em meados do século XIX por uma massa de escravos que não passava de dois milhões de indivíduos. Por tais peculiaridades, qualquer que fosse o empreendimento econômico que se quisesse realizar, e levando em consideração a expansão que se verifica na economia cafeeira, teria de se chocar com a inelasticidade de oferta de trabalho (FURTADO, 1982, p。117).

Com a eliminação do tráfico de escravos $(20) \mathrm{em}$ meados do século XIX, a questão da mão-de-obra se agravava e passava a exigir solução urgente. Essa si iuação era agravada na medida em que a demanda de escravos nas plantações do sul provocava uma nova intensificação do tráfico interno em pre-

(20) Em I826, por pressões da Inglaterra, o Governo Imperial ratifica os acordos feitos anteriormente com Portugal de proibição do tráfico ao norte do Equador e de visita a navios suspeitos de tráfico - obrigando-se, ainda, a interromper o tráfico em 3 anos; em 1831 é promulgada a Lei proibindo o tráfico para o Brasil e declarado livre os africanos aqui chegados dali por diante; em 1845 é decretado o Bill Aberdeen, através do qual a Inglaterra se propunha a extinguir o tráfico negreiro, usando de todos os meios, até mesmo a invasão do território nacional; com a pressão inglesa, em 1851 é aprovada a Lei Euzébio de Queiroz que proibiu o tráfico no Brasil. Para maior aprofundamento, ver PRADO JR. (I982, p。145-153); CANO (I981, p. 25-26) e NELLO (1975, p。 54) 
juízo das regiões que já estavam operando com rentabilidade reduzida; mais grave foi a situação, agravada pela drástica redução da oferta de trabalhadores cativos e consequntemente elevação de seus preços, que provocou uma intensificação na utilização da força de trabalho e, portanto, um desgaste ainda maior da população escrava (Idem, p. 119).As possibilidades de expansão econômica sobre a base do trabalho escravo eram, portanto, muito limitadas, embora a produção continuasse apciada ainda sobre o trabalho escravo.

A questão da disponibilidade de força de trabalho era, pois, essencial à manutenção da acumulação na economia cafeeira. A solução do problema era imprescindível e, caso não se encontrasse uma saída, a economia mercantil-escravista inevitavelmente entraria em crise, tendo em vista que:

$$
\begin{aligned}
& \text { "... os preços explodiriam... } \\
& \text { (e) a empresa cafeeira iria se } \\
& \text { atrofiando a medida que conta. } \\
& \text { se, cada vez mais, com um me- } \\
& \text { nor número de escravos." } \\
& \text { (MELIO, 1975, p. } 57 \text { ). }
\end{aligned}
$$

As soluções, como já se disse, eram buscadas por vários caminhos - tráfico interno, migração evropéia, etc. que agravavam ainda mais a crise, já que aprofundavam a contradição representada pelo trabalho escravo.

Nesse sentido, porém, é necessário que se considere que a "abolição foi progressiva" e seguiu, de fato, o desenvolvimento do mercado de trabalho - o que implica uma contradição particular: a abolição progressiva foi uma medida mais política que econômica, incapaz de promover uma transformação econômica na forma da prozução. Assim, a manutenção da escravidão constituía-se num fator de estagnæção econômica, que impunha barreiras à acurnulação de capital (FURTADo, 1982, p. 
136-141). Dito de outra forma, a "abolição progressiva" não implicava "introdução progressiva" do trabalho assalariado"; e ¿̀ medida que isto não ocorria, retardava na mesma proporção o desenvolvimento do capitalismo no Brasil: "ao defender as antigas formas de dominação. . as classes dominantes retardavam a própria acumulação." (SILVA, 1980, p.47).

Ademais, o desenvolvimento das forças produtivas repunha a todo o momento a inadequação do escravismo, enquanto relação social de produção com caráter nitidamente anti-progressivo, face às condições profundamente progressistas do capitalismo. A essas dificuldades, outra vinha somar-se: não havia condições para transformar a força de trabalho em mercadoria, pré-requisito indispensável ao modo de produção capitalista(2l). A estrutura econômica brasileira possibilitava que os homens livres pudessem ser produtores de sua própria subsistência, reproduzindo desta forma sua força de trabalho (cf. NIELIo, 1975, p. 77). Para que o trabalhador venda sua força de trabalho ao capital, é necessário que seja desprovido ou não tenha acesso (sob a condição de posseiro, agregado ou pequeno proprietário) de todo meio de produção (SIIVA, 1980, p. 45). Era pois, outro sério limite que tinha que ser superado.

A segunda condição fundamental da economia mercantil-escravista cafeeira nacional aponta para a disponibilidade de terras onde a produção puäesse ser lucrativa。 Isto

(21) Sobre as condiçoes cara a transformação da força de trabalho em mercadoria, seria interessante ver como essas transformações se deram no decorrer do processo de formação do Modo de Prodiação Capitalista - MARX (1982, Livro I, Volume II, Caps. XXIV e XXV, p. 828-894). 
significava que a acumulação se realizaria se contasse, continuamente, com novas terras próprias à cultura cafeeira, supondo que esta se daria sob uma técnica predatória, extensiva e invariável (MELIO, 1975, p. 58). Como se sabe, um dos fatores indicados como responsável pela expansão do café foi a abundância de terras. Porém, essa abundância de terras é algo profundamente relativo, já que a abundância de terras para o capital está necessariamente associada à não abundância deste meio de produção àquelẹs que devem constituir o mercado de trabaiho (SILVA, 1980, p. 73).

É sintomático que no ano em que se proíbe o tráfico negreiro - 1850 - e no momento em que a questão do suprimento de força de trabalho precisa encontrar uma solução, criou-se uma legislação definidora do acesso à propriedade deste principal meio de produção, a terra. A Lei de Terras de 1850, como ficou conhecida, rezava que todas as terras devolutas só poderiam ser apropriadas mediante a compra e venda, e que o governo destinaria os rendimentos dessas transações para financiar a vinda de trabalhadores imigrantes europeus. Com esta medida, pretendiam-se solucionar dois problemas ao mesmo tempo: por um ladc, restringia-se o acesso às terras - devolutas ou não - apenas àqueles que possuíssem capital para adquiri-las; por outro lado, criavam-se as bases para a organização de um mercado de trabalho livre que substituísse o sistema escravista. ('SIIVA, 1982, p. 24-25).

Com essa medida, a expansãc cafeeira poderia continuar, ao menos teoricamente. Porém, a ocupação de novas terras encontrariam novos limites que precisariam ser superados. Im primeiro lugar, as terras sobre as quais o café se estende são de dois tipos (SIIVA, 1980, p。70-71): 1) as terras que já 
tinham juridicamente proprietários; 2) as terras que juridicamente não tinham proprietários. As primeiras eram chamadas propriedades e as segundas terras devolutas.

Na verdade, as terras devolutas não eram obrigatoriamente não ocupadas ou não apropriadas; seus ocupantes podiam simplesmente não possuir os títulos de propriedade. Na medida em que as fronteiras do café deslocavam-se para o interior, a proporção de terras consideradas devolutas tornava-se maior. A tendência da expansão cafeeira era de ocupar, apropriar essas terras. Isto era juridicamente fácil: bastava estabelecer um título de propriedade, o que era fácil para a burguesia cafeeira que controlava hegemonicamente o poder. Do ponto de vista prático, bastava que os ocupantes fossem expulsos.

Entre os ocupantes, havia brasileiros de descendência européia, que vivíiam apoiados numa agricultura de auto-subsistência. Havia também tribos indígenas, que habitavam as terras há séculos. Esses "ocupantes" ofereceram forte resistência aos novos conquistadores, sendo necessárias verdadeiras batalhas para que as terras se tornassesm efetivamente disponíveis para as plantações de café (Idem, p. 7I).

Quando o capital encontrava no caminho terras que já tinham proprietários, ocorriam duas soluções: que a propriedade se integrasse à expansão cafeeira ou fosse vendida。 Qualquer que fosse a situação portanto, chesava-se ao mesmo resultado: à dominação do capital.

A terra em si não tem um valor; ela possui um preço na medida emi que representa um meio para a acumulação do capital (Idem, p. 72). Neste ponto, encontra-se outro sério limite para a realização da economia cafeeira: ocupar novas 
terras propícias ao café exigia altos investimentos iniciais. A partir de certo momento, a interiorização provocaria a elevação persistente do custo dos transportes, que ao promover uma elevação contínua dos custos de produção, provocaria a queda também contínua da taxa de lucro, até o ponto em que a acumulação não fosse compensadora (MELLO, 1975, p. 59).

A elevação dos custos dos transportes poderia ser solucionada pela adoção de técnicas que tornassem mais produtivas a produção, porém a suposição de técnica constante, inclusive nos transportes era um tanto irrealista (Idem, D.59), posto que "... dentro dos quadros da economia mercantil-escravista o escravo, enquanto escravo, é incapaz de manejar "produtivamente" técnicas que impliquem o emprego de máquinas." (Idem, p. 54). Em outros termos, a escravidão requer o recurso sistemático e direto da violência, o que coloca os escravos entre os trabalhadores menos adaptados ideologicamente às formas superiores de dominação do capital (SILVA, 1980, p. 46).

Outra alternativa possível para ampliar a produtividade e conservar positiva a acumulação, era o … replantio dos cafeeiros em terras da "velha zona", ao mesmo tempo em que se promovia a recuperação do solo. Deve-se ponderar, porém, que a reposição total da terra dificilmente ocorreria, já que com a existência de limites móveis da fronteira agrícola, os empresários cafeeiros empregariam técnicas predatórias, evitando despesas desnecessárias (MELLO, 1975, p。60)。

Tais fatos levam o autor de 0 Capitalismo Tardio a reiterar sua conclusão de que ".. a economia cafeeira tenderia a uma lenta e inexorável regressão." (Idem, p. 60)。

A análise a seg̃uir dirige-se à realização da eco- 
nomia cafeeira escravista face às condições da demanda dos mercados externos. Antes de mais nada, é necessário que se distinga dois momentos: o de generalização e o de pós-generalização •

o período de generalização coincidiu com o período em que se verificava um crescimento da oferta brasileira a partir de 1830 - o que significou a queda dos preços para que o consumo se integrasse ao consumo popular dos países industriais.

No período de pós-generalização não se delinearia nenhuma tendència definitiva de preços, mas se estabeleceria um "limite superior", acima do qual o café deixaria de ser consumido popularmente. Esse limite superior impunha movimentos oscilatórios nos preços do café no mercado internacional, provocados pelo caráter permanente da cultura cafeeira, pelas condições da demanda externa e pela intervenção de fatores naturais. Esses mcvimentos oscilatórios dos preços provocariam, por sua vez, uma tendência cíclica na economia cafeeira.

Esse caráter cíclico que a economia cafeeira assumiu foi delineado pelo seguinte movimento: a expansão da economia cafeeira começou com a subida dos preços internacionais, provocada ou pela expansão dos mercados importadores, ou pela contração da oferta devido a fatores naturais. Com a subida dos preços internacionais, crescia a taxa de lucro das empresas em operação e, consequentemente, sua taxa de acumulação. Com o aumento da taxa de Iucro, novas inversões foram feitas no setor iniciando a construção de nova capacidade produtiva。Com o aumento da capacidade produtiva, os preços internacionais cairiam. Com a depressão da taxa de Iucro, a acumulação se estancaria (MELLO, 1975, p. 50 e s.). A partir dis- 
so, novo ciclo se iniciaria com novas subida de preços...

Pelo que foi exposto," pode-se concluir que o

crescimento dos preços não resolveria a tend̂̂ncia à queda da taxa de lucro da econcmia mercantil-cafeeira nacicnal, posto que a acumulação encontrava diversas barreiras além da imposta pelo mercado:

"... 1) em última instância esbarrava na disponibilidade de terras em que a produção pudesse ser lucrativa; 2) em primeira instância estava bloqueada pelo aumento dos custos dos transportes; 3) o problema da reprodução da força de trabalho escravo poderia . o. ser contornado..." (MEILO, 1975, p。63)。

A qũestão da demanda dos mercados externos está intimamente relacionada à cutra: a da balança comercial brasileira。Já se destacou o caráter da econcmia brasileira no período: grande empresa, produzindo em massa, apoiada no latifúndio e no trabalho escravo, com o controle nacional da produção e do comércio, e articulada ao sistema comercial-financeiro internacional. Foram tais características que especificaram o sentido da economia mercantil-escravista, ou seja, de uma economia complementar, subordinada às condições de reprodução dc capital industrial, inicialmente, e, depois, do capital financeiro, em âmbito mundial. Essa reprodução dava-se através da circulação internacional, não mais de mercadoriais, mas do mercado de capitais, que visto sob uma perspectiva mais ample sienificava ver as próprias condições através das quais passa a se dar a reorodução do capital. 
A forma dominante de exportação de capitais no período da economia mercantil-escravista cafeeira foi a dos empréstimos públicos, assim entendido:

"O empréstimo, por definição, deve ser reembolsado com juros. No fim de um certo período mais cu menos longo, o país que tornou o empréstimo deve devolver todo o dinheiro emprestado e, além disso, uma certa quantia como pagamento de juros e comissões; isto é, ele deve devolver uma quantia maior dc que a recebida inicialmente." (SILVA, 1980, p. 33 )。

Im seguida, foi exposta a questão do balaņ̧o comercial brasileiro e o papel desempenhado pelos empréstimos e qual a implicação disso para a economia mercantil-escravista.

o comércio internacional do Brasil entre 1821 e 1860 foi quase permanentemente deficitário: acumulou-se no período um deficit global de 233.923 contos de réis, não se computando nele a importação de escravos africanos que representavam cifras consideráveis (PRADO JR., 1982, p. 133)。

Ao desequilíbrio financeiro provocado pela balança de comércio, o setor público provocava um agravamento crescente dessa situação, pela conjugação de vários fatores: inicialmente pela transferência da corte portuguesa ao Brasil, com todo o aparato do Estado-administrativo, jurídico e militar - acrescido da criação em terras da colônia de alguns serviços indispensáveis - como a ampliação da armada, serviços de educação e saúde pública, abertura de estradas a ampliação dos portos, etc. Independente o Brasil, nada se alterará nessa situação, aliás, agravada pela necessidade de todo o aparato 
necessário à organização e funcionamento do Estado - apareIho jurídico, administrativo e militar-repressivo, etc.

O tesouro público já não contava com grandes recursos para enfrentar esse aumento crescente dos gastos. A renda mais sesura e fácil de ser cobrada era constituída pelos impostos alfandegários, que produziam a maior parte da arrecadação pública. Mas esta era muito limitada em razão dos tratados internacionais que fixavam a tarifa a uma insignificante taxa de $15 \%$ ad valorem. Desta forma, o Brasil viveu em constante deficit orçamentário, com conseqthencias óbvias: não pagamento sumário dos compromissos, funcionalismo em atraso, dívidas proteladas, emissões de papel moeda de curso forçoso que sucediam a jato contínuo, etc. (Idem, p. 138-139).

0 deficit foi saldado pelo afluxo de capitais estranseiros, sobretudo sob a forma de empréstimos públicos: em 1825 o Brasil empresta 3.000.000 de libras; em 1829 o empréstimo foi de 400.000 libras; em 1839 de 312.000 libras; em 1843 de 732.000 libras e em 1852 de $\mathbf{1 . 0 4 0 . 0 0 0 ~ l i b r a s ~ ( P R A D O ~ J R . , ~}$ 1982, p. 138). Porém, essa não era a solução já que agravava o mal para o futuro, pois siginificava novos pagamentos sob a forma de juros, dividendos, amortizações - portanto, novos fatores de desequilíbrio da balarça externa de contas (Idem, p. 133).

"(...) Mas"os empréstimos externos representam apenas $c$ alívio momentâneo: jé vimos seus efeitos nocivos soore c balanço externo de contas;eles não serão menos desfavoráveis com relação às finanças públicas, sobrecarregando-o em proporção crescente de compromissos que logo ultrapassam sua 
capacidade normal de pagamento. Em meados do século, serviço das dívidas já absorvia $40 \%$ do total da receita." (PRADO JR., 1982, p. 139).

A partir de 1860, o comércio exterior começava a ser saldado invariavelmente com superavits crescentes, isto apesar de uma importação que se avolumava, mas que permitiu não sumente melhorar o padrão de vida da população, mas também e principalmente promover o desenvolvimento das forças produtivas, com o axarelhamento técnico do país: as estradas de ferro e outros meios de comunicação e transportes, mecanização das indústrias locais, instalação de algumas primeiras manufaturas (Idem, p. 168). Essa situação da balança comercial pode ser auferida pelos saldos do período: que entre 1851-1860 foi negativo em -II, 6 contos de réis; entre 1861-70 o superavit foi. de 18,9 contos de réis; entre 1871-80 o saldo positivo salta para 34,3 contos de réis, caindo sensivelmente na década seguinte - 1881-90, para 30,9 contos de réis (SILVA, 1980, p. 35).

Entre os vários fatores que contribuíram para o "restabelecimento" econômico nacional, não há dúvida de que os principais foram as inversões de capitais externos, notadamente de Inglaterra.

Tomando os dados dos empréstimos ingleses por decênio, pode-se perceber o rápido crescimento dos investimentos britânicos no Brasil a partir da década de 1860, principalmente: 1865 - 20,3 milhões de libras; 1875 - 30,9 milhões de libras; 1885 - 47,6 milhões de libras e 1895 - 93,0 milhões de libras (SILVA, 1980, p.36). A importância desses investimentos na economia brasileira durante a sesunda metade do século 
XIX pode ser demonstrada, levando-se em conta o valor das exportações brasileiras no período e comparando-os com os dados anteriores: 1850 - 8,1 milhões de libras; 1860 - 13,4 milhões de libras; 1870 - 15,5 milhões de libras; 1880 - 21,2 milhões de libras; 1890 - 30,0 milhões de libras (Idem, ․ 37).

A visão panorâmica desses dados comprovam que malgrada a efervecência econômica nacional, nada ficou no Brasil, que durante o período foi quem efetivanerte "exportou" capitais.

Quanto à questão do financiamento da produção e do capital cafeeiro, antes de mais nada, é preciso que se tenha em conta que o processo de desenvolvimento da cafeicultura, foi o processo de formação da burguesia cafeeira. Isto equivale a dizer que o desenvolvimento da economia cafeeira foi o desenvolvimento do capital cafeeiro. (SIIVA, 1980, p. 59). Os estudos de FRANCO (1969, p. 171 e s.) indicam que o "comissário"financiava e geria os investimentos feitos na economia cafeeira; isto é: o "comissário", além de manipular de modo explícito o seu capital no circuito comercial, o empregou (sob a forma de investimento) no processo de produção de mercadorias. Ao controlar o investimento e dominar a venda de mercadorias, criava as condições de valorização do seu capital, sem contuáo, se submeter aos riscos que a atividade produtiva na agricultura carregavam.

Isso significava que o capital mercantil continuava sendo dominante na atual economia nacional: primeiramente, pela ação do "comissário", cujo auge se situa por volta de 1850; a partir daí, pelos bancos cafeeiros que começaram a se formar e compartilhar com os comissários o controle da ativi- 
dade econômica.

A dependêr.cia aos comissários e ou aos bancos cafeeiros era alimentada por dois fatores: 1) pelo fato dos investimentos necessários à empresa cafeeira serem muito altos e o retorno (advindo da produção) não ser a curto prazo; 2) como a estrutura de comercialização e financiamento exigiam maciço investimento inicial, revelava-se altamente concentrada. Por tal situação, o fazendeiro estava preso ao círculo de ferro da dominação do capital mercartil. Porém, o capital mercantil tam bém se prendia num ou noutro círculo de ferro: ao se apropriar da quase totalidade dos lucros auferidos pela produção-comercialização cafeeira, necessitava reaplicá-los na empresa cafeeira, como única forma de proceder continuamente à sua valorização (NELLO, 1975, p. 64-65).

Não é difícil de se entender esta situação: os mesmos homens que estavam à frente das empresas desenpenhavam. as funções mais diversas na economia, estando também à frente do aparelho de Estado, seja ao nível regional, seja ao níveI nacional (SIIVA, 1980, p。59).

Isso significava, portanto, que o capital cafe-. eiro tinha diversos aspectos: apresentavam-se ao mesmo tempo as características de capital agrário, capital industrial, capital bancário e de capital comercial. Isso se explica porque:

"Na economia cafeeira, ca racterizada por um grau ainda fraco de desenvolvimento capitaIista, essas diferentes funçōes são reunidas pelo capital cafeeiro e não definem... frações de classe relativamente autônomas: não havia uma burguesia agrária cafeeira; - uma burguesia comervial, etc., mas 
uma burguesia cafeeira exercen do urintipias funcões." (SIIVA, ig80, r. 60).

Novamente é necessário que se ressalte a dominação comercial sobre as demais:

"A dominânoì du capital comercial é, em primeiro lugar - resultado do desenvolvimento ainda fraco das relaçoes de produ.ç̃o capitałistas no Brasil。 $(0 .$.

Em sesundo lugar, a dominação do capital coneroial exvlica-se rela posição ocupada pelo Brasil no sejo da economia mundial. Dado o fraco desenvolvimento de suas forças produtivas, o Brasil se vê designado na divisão internacional do trabalho, a posìção de país exportador de produtos agricolas. Esae efeito do desenvolvimento das relações capitalistas mundiais... manifes ta-se por ame deperdência em relação ao mercado mundial. Essa dependência vero reforçar - papel dominante ào comércio na economia cafeeira e na economia brasileira em geral." (SILVA, 1980, p。 б́l-52)。

Conciuindo, se com a economia mercartil-escravista nacional desapareceu o monopólio do comércio colonial, em seu lugar surgiu o oligopsônio comencial e o oligovólio financeiro que através da manipulação dos preços de compra e da fixação de elevadíssimas taxas de iuros, acabarain resultando numa situação similar à anterior: a dominacẽo do capital mercantiI (MELIO, 1975, $p .65$ ). 
4.4. A Crise da Economia Mercantil-Escravista $\supseteq a$ Emergência do Trabaliho Assalariado

A crise da econcmia mercantil-escravista cafeeina era indício claro de que havia poucas "chances históricas" de implantaçăo da "grande indústria escravista". As razões que explicam o fato da crise näo ter sido resolvida através da constituiçăo da grande indústria escravista, "em última instân cia, recai na produção, pois o que contrasta é o caráter progressivo do capitalismo e a natureza anti-progressiva da economia mercantil-escravista." (NGIIO, 1975, p.74)。o escravo se adequava ao processo produtivo por coação; o trabalhador assalariado, ao contrário, se ajusta ao processo produtivo por se sentir recompensado pelo salário. Ademais, a escravidão bloqueava tanto a maior divisão técnica do trabalho, quanto a especialização do escravo, já que a condição de escravo exigia que se mantivesse submisso. Também, é irracional que o empresário elevasse o grau de mecanização, sem que antes tivesse esgotado a "vida útil" de parte de seu equipamento, represertado pelo escravo (Idem, p: 73).

Pelo que foi aralisado arteriormente, fica claro cue a razão básica do bloqueio ao desenvolvimento econômicc nacional estava na existência de um "mercado de trabalho vazio" (Idem, p. 75). Evidentemente existiam romeris, conivdo, as possibjlidades de que estes se transformessem erl trabalhadores surmetidos ao capital eram äificultadas pela forme como estavam inseridos ra estrutura econômica: onde a produção não estava apoiada no trabalho escravo, predominava um regime que prendia o trabalhador à terra, através do uso de vários meca- 
nistnos atzeirés dos quais a força de trabalho potencial reproduzia suas condições de produção (SILVA, 1980, p. 42; FURTADo, 1982, p. 120). Em outras palavras, a economia mercantil-escravista cafeeira colocava os homens livres e pobres à margem, pois embora fossem dispensáveis à estrutura produtiva, não estavam à disposição do capital enquanto força de trabalho passível de transformar-se em mercadoria ${ }^{(22)}$ 。

Não evoluiu, assim, pela oferta interna a resolução da problemática situação da oferta de força de trabalho, acrescida da hostilidade a toda transferência interna de mãode-obra, uma vez que os interesses de parte da aristocracia latifundiária seriam prejudicados (Ver FURTADO, 1982, p。122 e a nota no 110). Tudo levava a crer que o desenvolvimento capitalista estava bloqueado, pois não havia condições de transformar a força de trabalho em mercadoria, pré-requisito indispensável ao modo de produção capitalista (23). Ao lado da "abolição proressiva" da escravidão, a imigração aparecia como a saída para aumentar a oferta de mão-de-obra。Antes, porém, era

(22) O aprofundamento dessa questão é feito por cosTA (1969, p. 12 e s.) e FURTADO (1982, p. 120 e s.).

(23) Estas condições de transformação da força de trabalho em mercadoria são assim compreendidas: "Para que o trabalhador venda sua força de trabalho ao capital, é necessário que ele não possa sobreviver senão da venda de sua força de trabalno; isto é, que ele seja despossuido de todo meio de produção. Essa condição material é uma condição primeira do desenvolvimerto do capital. Mas é necessário ainda que o trabalhador esteja disposto (ideologiamente), a vender sua força de trabalho e que ele não prefira, à condição de assalariado, a miséria e a medicidade. (...)" (SILVA, 1980, p. 45). 
necessário criar as condições para a transformação da força de trabalho em mercadoria. Assim, em 1850, ao mesmo tempo em que ocorria a proibição do tráfico negreiro, se criava uma legislação que definia o acesso à propriedade da terra - a lei de terras de 1850. Esta lei estabelecia legalmente a propriedade privada, definia a forma de acesso ao principal meio de produção agrícola (a terra) - compra e venda - e estabelecia o destino dos rendimentos obtidos pelo Estado com a transação das "terras devolutas" - financiar a vinda de imigrantes europeus. Isto quer dizer que enquanto a mão-de-obra era cativa, o latifúndio podia até conviver com terras de acesso livre; porém, quando é necessário que a mão-de-obra se transforme em formalmente livre, as terras, enquarto principal meio de produção agrícola e de produção das condições de reprodução da existência = tem que ser escravizadas pelo regime de propriedade (SII $\mathrm{VA}$, i $982, \mathrm{p} .24-25)$.

Desta forma, na medida em que ocorria o desenvolvimento econômico, a economia mercantil-escravista aprofundava sua crise; na medida em que se buscava a superäcão da crise, reforçava-se a dominação do capital sobre o trabalho. Por um lado, a contradição estrutural representada pelo trabalho cativo tinha que ser eliminada; por outro lado, o desenvolvimento capitalista impunha renovadamente a adequação das relações sociais de produção capitalistas ao desenvolvimento das forças produtivas:

\footnotetext{
"(...) Na medida em que o trabalho se torna assalariado, o produtor se torna capitalista industrial; por isso, a produção de mercadorias, só aparece
} 
em toda sua extensão quando o produtor agrícola direto é trabalhador assalariado。 $\mathrm{Na}$ relação entre capitalista e assalariado, a relação monetária passa a ser relação entre comprador e vendedor, relação imanente à propria produção . (...)" (MARX, 1980, IIVro 2,' Volume 3, p. 118-119)

Convém salientar, porém, que o processo histórico em que se dá a crise da economia mercantil-escravista cafeeira e os mecanismos que produziram as transformações qualitativas nas relações de produção, foi produzido por uma multiplicidade de ocorrências profundamente interrelacionadas e interdepen dentes. Para efeitos analíticos considera-se que a passagem que se deu no desenvolvimento do capitalismo no Brasil só pode ser entendida se for levado em consideração que as mudanças ocorridas nas relações de produção se deram sob a determinação das forças produtivas ${ }^{(24)}$ :

(24) E importante a ênfase de qual o aspecto determinante da transformação da produção, na medida em que teóricos tendem a confundir esta questão, como, por exemplo HINDE:Ss e HIRST (1976, p. 16-19), que ao tratarem da transformação dos modos de produção, afirmam: "(..) consideramos aqui as relações de produção como o elemento primordial do con ceito de modo de produção. (...) E impossível construir o conceito de uma combinação articulada de relações e forças de produção, partindo do primado das forças produtivas. (...)" ( p. 19)。

Fundamenta-se teoricamente a determinação das forças produtivas na transformação qualitativa das relações de produção, partindo de MARX ( 1980 , Iivro III, Vol。IV e VI, ‥278, 281-282, 286-295, 302-305 e IOII)。 
"(...) Ao subir os planaltos de São Paulo, as plantações abandonam o trabalho escravo pelo trabalho assalariado, a produção cafeeira conhece a mecarização... Além disso, a possibilidade desse deslocamento é determinada pela construção de uma rede de estradas de ferro bastante importante. Finalmente, o financiamento e a comercializaçao de uma produção que atinge milhões de sacas implica o desenvolvimento de um sistema comercial relativamente avançado, formado por casas de exportação e uma rede bancária." (SIIVA, 1980, p. 50).

o escravismo não se desintegrou nem deixou de ser dominante a curto prazo. A abolição, como se viu, foi gradativa e seguiu os rumos da formação de um mercado de trabalho assalariado •

"A solução vislumbrada, desde o início, foi a imigração. Como se tratasse de "colonizar para o capital" e não colonizar para povoar, para ocupar vazios territoriais, a introdũ̃ão de núcleos de colonizaȩão, nada valia, era puro desperá́cio..." (NEIIO, 1975, p。 83)。

Mesmo assim, as primeiras tentativas para suprir mão-de-obra livre se deu com a imlementação ae núcleos coloniais. As tentativas oficiais, desencadeadas pelo Império, nes te sentido, resvalavam em fortes oposições: afirmava-se que necessitava-se de braços para a lavoura e não núcleos de povoamento "... que consumiam verbas governamentais e revelavam- 
-se, o mais das vezes, ineficazes e improdutivos. ..." (COSTA, $1966, \mathrm{p} .65)$.

Com a derrocada do sistema de colonização, tentou-se a parceria. Como as tentativas de colonização haviam fracassado, pensava-se na época em transferir para a iniciativa privada a responsabilidade de promover a imigração, sendo que a administração do Império apoiava as iniciativas desse gênero, pressionados pelos que viam na parceria a solução para a substituição do escravo (Idem, p。78-80).

O interesse pela colonização cresceu a partir de 1850, com a cessação do tráfico e a criação de aparatos jurídicos que impedissem a auto-subsistência, sendo que os resultados aparentemente vantajosos conseguidos pelo Senhador Vergueiro, em sua fazenda de nome Ibicaba, localizada em IimeiraSP, encorajavam os fazendeiros a seguirem seu exemplo (Idem, p.80)。

Essa forma de exploração da força de trabalho, com uma parte em dinheiro e autorização para o plantio de subsistência, era na verdade um instrumento utilizado pelo capital, quando seu desenvolvimento ainda não era grande, para reduzir os custos com capital variável, na medida em que o próprio trabalhador se responsabilizava por parte da reprodução de sua força de trabalho, além de possibilitar uma parcela de renda em espécie, graças à meação imposta ao colono.

O insucesso do sistema de parceria foi grande, sendo que fazendeiros e parceiros manifestavam por toda parte seu descontentamento e decepção。A situação nem poderia ser diferente, pois colonos e fazendeiros tinham objetivos diametralmente opostos: 
"(..) O que desejavam os fazendeiros era converter os par ceiros em proletários e não fomentar futuros concorrentes. o que ambicionavam os parceiros não era de se proletarizarem, mas sim, se transformarem em proprietários, encarando sua condição como espécie de etapa para formar um pecúlio, - bastante para dar o 'salto'." (MELIO, 1975, p。85)。

Com a decadência do sistema de parceria e/ou com sua precária existência, a falta de mão-de-obra continuava a ser um problema que exigia solução. A partir de 1860, a questão da oferta de mão-de-obra tornou-se particularmente séria em consequência de dois fatores: a melhoria dos preços do café tornava atrativa a expansão da cultura; a alta nos preços do algodão, provocando o aumento da produção no nordeste, restringiu o tráfico de escravos para o sul (FURTADO, 1982, p. 126-127). Porém, por volta de 1870 as condições econômicas sofreram modificações, criando perspectivas para o trabalho livre: os altos preços do café no mercado internacional, a meIhoria das vias de comunicação, o aperfeiçoamento dos meios de transporte, a possibilidade de emprego de processos mecânicos para o beneficiamento do café, o fenômeno da urbanização, o crescimento da população, etc. (COsTA, 1966, p. 188).

Era patente a necessidade de mão-de-obra que se dirigisse à empresa cafeeira, mas que se caracterizasse por um fluxo abundante e de homens pobres. Pobres, a ponto de não poderem nem pagar sua passagem, nem comprar a sua terra, ou abrir um pequeno negócio, mas tão somente em se cons tituirem em trabalhadores. Abundante, porque somente assim se 
obteriam baixas taxas salariais, impedir-se-ia que se transformassem em posseiros ou pequenos proprietários, ou que fossem para as cidades e acabassem se dedicando a atividades artesanais ou a trabalhos marginais。

Concomitantemente, as transformações ocorridas em algumas economias européias "atrasadas" no final do século XIX, constituíam um grande contingerte de homens dispostos a emigrar, o que se tornou possível graças à "revolução dos transportes", operada pelo barco metálico (NEIIO, 1975, p.86)。

Restava uma questão: tinha-se que definir uma política capaz de enfrentar a concorrência dos Estados Unidos e da Argentina. A solução gradativamente vai se forjando, com o Governo Brasileiro e, principalmente, da Província de São Pau1o, subvencionarido a vinda de imigrantes de várias maneiras $(25)$. Porém, em 1885, quando os preços do café começaram a subir, elevando consequentemente a taxa de lucro efetiva, a falta de mão-de-obra torna-se crítica e passava a exigir solução urgente. Nesse ano, o Governo de são Paulo toma uma série de medidas: financiava os gastos com a imigração em sua tota-

(25) Em março de 1871 é baixada a Lei Provincial no 42 que autorizava o governo a emitir apólices de até seiscentos contos para auxiliar o pagamento das passagens dos imigrantes; por um decreto de 08 de agosto de 1871, era cons tituida a "Associação Auxiliadora da Colonização"; em 1874, pela Lei 44, a Associação recebia cem contos para colaborar no financiamento da passagem dos imi grantes; pela Lei Provincial no 36, de 21/02/1881, eram consignados cento e cinquenta contos para o pagamento de passagens e se determinava a construção de uma hospedaria para os jmigrantes。 Em 1884 e, depois, em 1885, novos créditos foram concedidos. Para melhor compreensão da importancia daimigração, bem como a subvenção dada pelo Estado, ver COSTA (1966, p. 188-202)。 
lidade, passando a contratar a importação de trabalhadores junto a companhias privadas, principalmente a 'Sociedade Promotora de Imigração"。 Também a União passou a empregar um terço (1/3) dos recursos, antes destinados à formação de um fundo emancipacionista, para subsidiax a imigração (MELLo, 1975, p. 87). Graças a essas subvenções dadas à imigração, ficava, por um lado, o colono liberado da dívida e, por outro, efetivava-se um fluxo imigratório constante para o Brasil (CO\$TA, 1966, p。190-191). As condiçọes, porém, em que a imigração era financiada eram explícitas: era para o café, pagando-se a passagem somente àqueles que se dirigissem para um estabelecimento agrícola (NELEO, 1975, p。87)。

Devido aos subsídios e ao decréscimo do poder de atração da economia norte-americana, a imigração acelerou-se extraordinariamente ${ }^{(26)}$. Com ela os salários puderam, então, cair substancialmente e a expansão cafeeira tomou grande. imprulso.

O trabalno assalariado, ao tornar-se dominante, trouxe consigo a condição básica para que a economia nacional, ainda que tardiamente, transformasse sua estrutura, adequando-a à do novo capitalismo. o abolicionismo que antes era um movimento social e político amparado, quase que exclusivamente, nos segmentos liberais urbanos, passou a receber o respaldo das cłasses proprietárias dos estados não-cafeeiros, bem como - do núcleo dominante da economia cafeeira. Abolicionismo e imigrantismo tornaram-se a mesma caisa, e em 1888 extinguia-se

(26) De 1875 a 1885 na Província de São Paulo ingressaram cerca de 42.000 imigrantes。 Em 1887 São Paulo recebeu 32.000 e em 1888 mais de 92.000 (Ver COSTA, 1966, D. 192-194).' outros dados globais revelam que o país recebeu perto de 260.000 imi grantes entre 1885-88 (MELLO, 1975, p.87)。 
a escravidão

A partir de abolição deu-se o verdadeiro surto de imigração para a área economicamente dominante, correspondendo a uma série de mødidas adotadas pelz administração (Ver cosTA, I965, p。 193 e sol)Assim, efetivava-se a mão-de-obra assalariada como relação de trabalho dominante e com isto marcava-se a passagem no Brasil da economia colonial, através da economia mercantil-escravista, para a economia exportadora capitalista。

O gradativo processo de extinção do trabalho escravo e a implantação do trabalho livre, ao lado do desenvolvimento da economia cafeeira no "oeste paulista", promoveram a mecanização de parte de. produção. Entre os aperfeiçoamentos introduzidos na economia cafeeira, merece destaque a mecanização da lavoura, com uso do arado de tração animal; introdução da máquina carpiđeira de tração animal; processos hidráulicos ou mecânicos na pilašem e ventilação; e principalmente introdução da máquina de beneficiamento (27), representada por um conjunto de equipamentos específicos, como os depalpadores, descascadores, ventiladores, brunidores, separadores/classificadores, modificadoras do tipo de café, etc。

A modernização técnica verificada na produção cafeeira, ainda que diminuta quantitativamente, trouxe conseqthências qualitativas que não podem ser subestimadas: significava que a mecanização, por um lado, aumertava ainda mais o fosso que separava os trabalhadores de seus meios de produção, porido fim ao sorho de muitos "colonos" que esperavam um dia

(27) Para una me Ihox compreensäo das causas e efeitos da introdução de aperfeiçoamentos nos processos da economia cafeeira, ver COSTA (1966, p. 176 e s.)。 
poder transformar-se em proprietários; por outro lado, dados os investimentos vultoscs que exigia, a mecanização passou a representar um importante elemento de manutenção da economia brasileira, axoiada nas Erandes plantaçoes, agora sob o domínio direto do capital.

Quanto aos efeitos que as inovações mecânicas provocaram nos processos de preparo e beneficiamento do café, podem ser assim sintetizados:

"As inovações mecânicas
estrangeiras ou nacionais
apresentavam-se como soluçoses
parciais para o problema da
mão-de-obra. Racionalizar o
trabalho era reduzir mão-de-
-obra necessária, multiplican-
do o rendimento. (...)"
(...)
"Esses processos mecâni-
cos visavam sobretudo a melho-
rar a técnica de beneficiamen-
to do produto. (...) Tudo isso
resultava num aperfeiçoamento
do produto que alcançava cota-
ções mais altas no mercado.
(....)" (costa, l966, p. l85-
l86-l87).

o desenvolvimento da economia cafeeira não teria sido possível, porém, sem as estradas de ferro. A introdução das estradas de ferro, comandada pelo capital mercantil nacional e apoiade pelo capital financeiro inglês, foi a única forma de rebaixar os custos dos transportes. Com as estradas de ferro, as distâncias deixavam de ser problema e todo o interion estava passível de ser conquistado pelos "pioneins" do café (SIIVA, 1980, p. 56; VEILO, 1975, D.79)。

Os efeitos da introdução da estrada de ferro so- 
bre a economia mercantil-escravista cafeeira, podem ser assim colocados:

"E fácil imaginar que com
sua construção uma verdadeira
revolução se operava na econo-
mia cafeeira: braços até então
desviados da lavoura porque
aplicados ao transporte que
podiam, agora, voltar-se para
as culturas; maior capacidade
de transporte, baixos fretes;
melhor conservaça do produto,
que apresentava qualidade su-
perior e obtinha preços mais
altos no mercado internacional;
portanto, possibilidades de
maiores lucros, novas perspec-
tivas para o trabalho assala-
riado." (costa, l966, p. l73-
l74).

Contraditoriamente, ao mesmo tempo em que o desenvolvimento técnico possibilitava a expansão da economia cafeeira, por outro lado, determinava sua transformação, ao provocar mudanças nas relações de prodiação (MELIo, 1975, p. 81 e So; SILVA, 1980, p. 58).

o conjunto dessas transformações fazem da economia cafeeira o centro da acumulação de capital baseada no trabalho assalariado. E foi neste contexto de acumulação de capital que nasceu a indústria no Brasil。 Isto significa dizer que as relaçoses entre café e indústria se definem no quadro de desenvolvinento do capitalismo no Brasil. 
4.5. Desdobramentos da Economia Mercantil-Escravista e Outros Aspectos da Economia Nacional

Não basta destacar o desenvolvimento econômico e as transformações ocorridas ao longo da segunda metade do século XIX, se não se destacarem os desdobramentos que a expansão da capacidade produtiva da economia cafeeira provocou.

Como se viu anteriormente, a produção cafeeira sofreu um rápido crescimento ao longo do século $X_{I} X^{(28)}$, que coincidiu com o momento em que a economia era submetida a gran des pressões por aumento das importações ${ }^{(29)}$, sendo que de $30 \%$ a $40 \%$ das importações se referiam a gastos com importação de alimentos (CANO, 1981, p。58).

Por se tratar de produtos essenciais à sobrevivência e reprodução da força de trabalho, era vital para a economia que as importações fossem substituidas por produção nacional. Vinculada à expansão cafeeira, notadamente graças ao regime do "colonato", deu-se o desenvolvimento e diversificação da agricultura paulista (Idem, p. 60).

Isto significa dizer que o desenvolvimerto da agricultura mercantil de alimentos se deu no seio da produção cafeeira, utilizando terras inaproveitadas pelo café e os"tem-

(28) A produção de café se multiplica a taxas elevadas: 0,3 mi Ihões de sacas de 1821-30; 1,0 milhão de sacas ertre 183I -40; 1,7 milhões de sacas ertre 1841-50; 2,6 milhões de sacas entre 1851-60; 2,9 milhöes de sacas entre 1861-70; 3,6 milhões de sacas ertre 1871-80 ( $\mathrm{cf}$. SIIVA, 1980, p. 49).

(29) As impoxtações "... saltam de uma média de 16 milhões de libras esterlinas na década de 1880, para cerca de 25 miIhões na década de 1890, subindo para mais de 30 milhões entre 1900 e 1910..." (CANO, 1981, p. 57)。 
po s sobrantes" da força de trabalho do colono. Mas, na medida em que o desenvolvimento capitalista da economia cafeeira passou a gerar um processo crescente de atividades afins (comércio, indústria, bancos) e de crescente urbanização, a estrutura econômica passou a reclamar também a expansão da agricultura de alimentos independente da atividade cafeeira e operando com recursos próprios (Idem, p , 60-6I). Além deste fator básico, outros foram responsáveis pelo crescimento da agricultura mercantil de alimentos: o aumento do protecionismo a esta atividade; as crises cíclicas da economia cafeeira, que criavam as pré-condições para a expansão diversificada da agricultura (mecanismo conversor do uso da terra e transferidor da proprie dade; expulsão de imigrantes, etc.); a entrada dos imigrantes, que mostravam a disposição constante de se libertar da condiçäo de colono do café e se tornarem arrendatários ou pequenos proprietários - produtores de uma agricultura diversificada (Idem, p.6I-62).

Da mesma forma que gerou o desenvolvimento

da agricultura mercantil de alimentos, a expansão da economia cafeeira provocou a expansão ou o surgimento de uma série de outras atividades, mais ligadas ao seü núcleo urbano: indústrias, bancos, escritórios, armazéns e oficinas de estradas de ferro, comércio atacadista, comércio de importação e exportação, etc. que requexeram, por sua vez, a expansão dos aparelhos de Estado. Na proporção em que estas atividades cresceram, outras vinculadas ao processo de urbarização também se desenvolveram: comércio varejista, transportes urbanos, comunicações, energia, construção civil, equipamentos urbanos, etc。

o deserv•Ivimento de outras atividades seguiu os 
caminhos da expansão da economia cafeeira e teve seu momento de grande aceleração a partir de 1880, quando a imigração tornou-se massiva, e mais especificamente, entre 1890-1900, quando a economia cafeeira alcançou seu mais acelerado desenvolvimento, graças ao trabalho assalariado (CAHO, 1981, p. 70 e s.). Entre as mitas atividades que se desenvolveram no encalço da economia cafeeira, destaca-se o desenvolvimento do comércio importador/exportador e a expansão do sistema bancário (Ver CANO, 1981, p。70-73; PRADO JR., 1982, p.192-193).

Pelo que foi abordado, fica claro que o setor econômico mais dinâmico, e por isso mesmo dominante, no período em estudo foi a. economia cafeeira, principal base do comércio exterior brasileiro(30).

Mas, o desenvolvimento da segunda metade do sécu10 passado não se estendeu a todo o território nacional (FURTADO, 1982, p. 143). Isto significa afirmar que não basta o estudo da economia cafeeira, notadamente da que se expandiu em São Paulo, para se entender o complexo econômico nacional。Tợna-se necessário, mesno que suscintamerte, o exame de outras economias regionais do país, dado ao inter-relacionamento de-

(30) A importância do comércio externo é salientada da sešuinte forma: "... a economia brasileira parece haver alcançado uma taxa relativamente alta na segunda metade do século XIX. Sendc o comércio exterior o setor dinâmico do sistema. . Comparando os valores médios correspondentes aos aros noventa com os relativos ao decênio dos quarenta, depreende-se que o quantum das exportações brasileiras aumentou em 214 por cento... Um aumento de 214 por cento do quantum das exportações, acompaninado de uma meIhora de 58 por cento na relação de preços do intercâmbio, sigrifica um incremento de 396 por cento na renda real gerada pelo setor exportador." (FURTADO, 1982, p. 142). 
las com o crescente predomínio do comércio cafeeiro de São Pau Io (CANO, 1981, p. 87)。 Para fiñ de análise, convém dividir a economia brasileira em três setores principais: a economia amazônica, a economia regional do nordeste e a economia do extremo sul。

A economia amazônica, com exceção do Maranhão, manteve-se, desde fins do século XVIII, em decadência, quando a atividade extrativo-florestal viveu a desorganização do sistema de exploração da mão-de-obra indígena estruturado pelos jesuítas。

Durante várias décadas, desde meados do século XVIII, as bases da economia amazônica continuaram a ser as especiarias extraídas da floresta, cuja penetração havia tornado possível os jesuítas. Dos produtos extrativos, o cacau continuava a ser o mais importante; porém, a forma como era produzido não permitia que o produto alcançasse aIguma significação econômica。 O aproveitamento comercial dos demais produtos florestais deparava-se sempre com a mesma dificuldade de organizar a produção com base na escassa mão-de-obra indígena (FURtado, 1982, p. 129-130).

Esses eram tambémi os problemas enfrentados pela produção de borracha, cuja exportação se registra desde 1820, crescendo progressivamente nas décadas seguintes: de 460 toneladas anuais médias nos anos 40; 1900 toreladas no decênio seguinte e 3700 toneladas nos anos sessenta (Idem, p. 130)。A partir de 1860, a atividade extratora da borracha pôde se expandir, gracas an aumerto dos preços do produto no mexcado internacional: de 45 libras por tonelada em 1840, sobe para 118 libras por tonelada no século seguinte, 125 libras por tonela- 
da nos anos sessenta e 182 nos setenta (Idem, p。130)。

Em linhas gerais, a produção da borracha se desenvolveu em dois ciclos. o primeiro, foi desencadeado por uma verdadeira invasão da floresta por bandos de "caucheiros" que devastaram quase todo o vale amazônicc em busca da castilloa elástica. Uma vez que as árvores tinham que ser abatidas para se extrair o látex, os bandos de "caucheiros" tinham de mover-se continuamente em busca de novos cauchais, cobrindo imensas distâncias, sendo que nenhuma tribo indígena em cujo território crescia a castilloa, pôde fugir do encontro desse verdadeiro exército móvel (RIBEIRO, 1977, p. 23).

A segunda fase iniciou-se quando começou a escassear a castilloa elástica, obrigando a exploração a refluir para as terras mais baixas do vale amazônico, pelas ilhas e terras marginais dos cursos d'água, em busca dos seringais dä hevea brasiliensis. Nessa produção, foram exploradas sucessivamente as zonas baixas do Amazônas, primeiro no Pará, depois o médio e o alto curso até o Solimões, já no Estado do Amazonas, e, finalmente, todos os rios tributários, desde a foz até a cabeceira (Idem, p. 23-24).

Nessa exploração extrativa, a terra não tinha um valor em si mesma, o mesmo em relação à floresta exuberante que a cobre。 O que interessava realmente eram as espécies consideradas úteis. Por isso, não se ccgitava ou disputava a posse da terra, como o que ocorria nas zonas de exploração agrícola e pastoril。 o que interessava (e continua ainda) era o domínio e - controle das vias de acesso aos seringais. O domínio dos cursos e dos meios de transporte era condição básica para o controle dos trabalhadores. Aí residia o problema da economia amazônica. 
De um ponto de vista inicial, a expansão da produção da borracha na Amazônia durante o período em questão, era um problema de suprimerto de mão-de-obra. Como se viu, a produção se expandiu e esse aumento de produção só pôde se dar ت̈raças ao influxo de mão-de-obra, pois os métodos de produção em nada se mcdificaram, como indica FURTADO (1982, p. 131135)。De acordo com este autor, a população da Amazônia mais que duplica entre 1872 e 1900, passando de 329.000 para 695.000 habitantes (3I)。

Visto de forma mais global, três razões dificultaram o desenvolvimento da economia anazônica: 1) a forma como se desenvolveram as relações de produção - o aviamento; 2) a baixa diferonciação da economia da borracha; 3) a profunda dominação do capital comercial sobre a produção (Ver CANO, 1981, p. 89-92)。

O segundo sistema econômico, formado pela faixa que se estende desde o Estado do Miaranhão até o Sergipe, excluindo-se a Bahia dado o fato de sua economia ter sido profundamente modificada nesta época pelo início da produção de cacau, é denominado de econcmia nordestina (FURTADO, 198?, p. 143-144; CANOO, 1981, p. 92-97).

A economia nordestina foi uma das que mais sofre-

(31) "Admitirdo-se um crescimento vegetativo de 1 por cento... depreendeu-se que o influxo externo teria sido da ordem de 260.000 pessoas, não contadcs aqueles que já haviam penetrado na resião que viria a ser depois o Território e Estado do Acre. Desse total de imicrartes, cerca de 200.000 correspondem ao último decênio do século, conforme se deduz dá comparação dos censos de 1890 e 1900. (...)" (FURTADO, I982, p. I31)。 
ram ccm a herança deixada pelo período colonial-escravista. Isso significa que a "alocação interna do excedente potencial" teve duas limitações durante o período colonial: por um lado, dado o fato de que as relações sociais de produção eram escravistas, o mercado interno era de exíguas proporções; por outro lado, dado o próprio caráter da economia colonial, essa economia foi montada ccm o objetivo básico de que a maior parcela possível do excedente fosse apropriado pela metrópole portuguesa ou pelas outras metrópoles parceiras de Portugal no jogo colonial (CANO, 1981, p. 92-93).

Passado o período colonial, mas permanecendo ainda a limitação imposta pelo escravismo, ume terceira contingência apareceu aprofurdandc a precária situação da economia nordestina: agravava-se o secular problema da queda dos rreços de seus produtos básicos, o açúcar e o algodão, em que pesava a lenta recuperação dos volumes exportados, que se processava ao longo do século XIX (Idem, p. 93).

Em linhas gerais é preciso acomrarhar o comportamerto dos dois principais produtos da economia nordestina: o açúcar e o algodão.

A situação da produção açucareira nordestina no decorrer do século XIX foi de aumento significativo do montante produzido e de contínua tendência à queda nos preços - o que vinha se verificando desde o início do século XVIII. Com referência aos preços do açúcar, estes caíram de 120 libras por toneladas no início do século XVII, para 72 librás a tonelada por volta de 1710, cerca de 30 no início do século XIX, 16 na metade deste século e 9 no início do século XX. Malgrado a contínua queda nos preços, houve recuxeração dos volumes exportados: no século XVII a média anual de exportações foi de 
30.000 toneladas, no século XVIII cairia para 20.000 , recuperanāo-se plenamente no século XIX, quando a média cnual de exportação chegou a suxerar 100.000 tcneladas (32). Este aumento da produção esbarrava, porém, com a crescente expansão do açúcar de beterraba, que chegou a dominar $50 \%$ já em 1882, atingindo $75 \%$ por volta de 1900 (Ver GNACCARINI, 1972, Primeira e Segunda partes)。Restava para a atividade açucareira nordestina somente a perspectiva do mercado nacional, observanao-se, entretanto, que este não se apresentaria muito promissor, dada à expansão da produção açucareira que ocorreria, tempo depois, no sul do país (Idem, ibidem).

Quanto ao algodão, excetuado o surto exportador ocorrido em meados do século XVIII, principalmente no Maranhão durante o século XIX, constituiu-se na princípal atividade econômica do complexo econômico nordestino, com um crescimento lento, mas persistente, passando de 110.000 para 190.000 toneladas, entre a primeira década do século XIX e a primeira do século XX (CANO; 1981, p. 94).

Entretanto, ao lado deste crescimento da produção algodoeira nordestina, a grande expansão da produção norte-ame ricana e mundial fez com que os preços do produto ficassem trinta por cento abaixo dos verificados no início do século XIX. Este aumento da produção, unido à queda dos preços, alto custo dos transportes e do tipo de embalagem requerida (tela de enfardamento), parece ter estimulado a insta-

(32) Os dados refierentes ao preço do açúcar foram compilados de Roberto C. SIMONSEI $\in$ os referentes a partir de 1821 do Anuário Estatístico do Brasil, ano de 1939-1940, citados por CANO ( $1981, p$. 93). Os dados referentes às exportações de açícar estão eni CAro (1981, p. 93). 
lação local das primeiras fábricas têxteis de algodão, produtora de sacos e tecidos grossos, já a tartir de 1850. Já no final do século passado, a expansão da indústria têxtil brasileira consumia cerca de 60 \% de algodão produzido no país, fazendo com que a produção nordestina encontrasse no mercadc interno a fonte para sua expansão (Idem, D。 194).

Porém, já a partir do início do século XX, a cotonicultura paulista avançou, operandc inclusive em bases técnicas mais eficientes, fazendo com que são Paulo dominasse a atividade por volta de 1930 - mais precisamente, com a "crise de 29". O nordeste, que era "produtor marginal no mercado internacional", passa a sê-lo também no "mercado nacional" (Idem, p. 195) .

Os demais componentes da economia nordestina como a pecuária, a agricultura de subsistência, o transporte ferroviário e a urbanização - não constituíram fatores dinấmicos capazes de impulsionar o desenvolvimentc, tal como ocorrera com a economia cafeeira.

Essa situação significa que pouco se poderia esperar da economia nordestina em termos de uma acumulação de capital, o que fica claro se se considerar o crescimento da população, comparativamente ao comportamentc do nível de renda: comparando-se os dados dos cansos de 1872 e 1900, verifica-se que a população nordestina aqui compreendida (Maranhão, Piaui, Ceará, Rio Grande do Norte, Paraíba, Pernambuco, Alagoas e Sergipe), aumentou a uma taxa anual de $1,2 \%$ 。 Isso significou um incremento deriográfico, na metade do século passado, de $80 \%$, que foi bem surerior ao da renda gerada pelo setor exportador, que foi de $54 \%$. Ainde que seja difícil de quantificar o nível de renda per caxita, cabe admitir que houve declí- 
nio, situando-se a sua taxa em torno de - 0,6 \% (FURTADo, 1982, p. 145 e 149)。

Como foi dito no início do estudo da economia ron destina, a Bahia foi deixada de lado, dada sua condição de excepcionalidade em relação ao resto da região. A produção de cacau que se inicia nesse Estado, para fins de exportação, no transcorrer da segunda metade do século XIX, proporcionou uma alternativa para o uso da terra e mão-de-obra que não beneficiou os demais Estados do Nordeste brasileiro. Contudo, a importância relativa do cacau em fins do século passado ainda era relativamente pequena, representando $1,5 \%$ do valor das exportações do país. Um outro produto tradicional da exportação baiana, o fumo, apresentou relativa recuperação no decor$r$ er da segunda metade do século, aumentando $361 \%$ entre os anos de 1840 e 1890 a quantidade exportada desse produto, observando-se uma subida de 41 \% nos preços médios do produto no mesmo período. Considerando conjuntamente o cacau e o fumo, o valor das exportações aumentaram de 151.000 para 1.057.000 Iibras, no meio sécuro referido (FURTADO, 1982, p. 146-147)。

Entretando, esses dados revelam somente urn aspecto do desenvolvimento baiano. De acordo com FURTAIO (1982, p. 147), também na Bahia "o desenvolvimento foi entorpecido pela ação profunda de fatores similares aos que atuaram no Nordeste", isto é, a melhoria de uma região ocorreu simultaneamente ao empobrecimento de outras. Ainda assim, a taxa de crescimento da Bahia evoluiu menos desfavoravelmente que a do Nordeste, situando-se em $0,0 \%$ a taxa de crescimento per capita para todo o Estado (Idem, ibidem). 
O terceiro sistema econômico, localizado no extremo sli. do país, estava formado pela economia de subsistência. Desde o século XVIII, essa região foi pioneira no abastecimerto do mercadc nacional, quando se dediccu à caça e criação de gado bovino, eqtino e muar, fornecendo-o às zonas mineradoras. Com a expansãc da economia exportadora, baseada principalmente na produção cafeeira, esta pôde se expandir, posto que encontrava no país um mercado caraz de absorver os excedentes de sua produção. Com isto, alguns setores da economia de subsistência puderam se expandir, graças à ampliação da faí xa.monetária de suas atividades produtivas (FURTADO, 1982, p. 144). Porénn, na medida em que a economia cafeeira se expandia no decorrer do século XIX, a produção de subsistência. do extremo sul passou a contar com outros competidores, tanto do exterior como de outras regiões do país, notadamente Minas Gerais, que após.a decadência do café, voltava-se para a produção de subsistência. Por outro lado, como já se viu anteriormente, a própria dinâmica da economia cafeeira ampliava consideravelmente sua agricultura, a ponto de em 1919 a agricultura paulista não-cafeeira equivaler a $99 \%$ da produçäo dos três Estados sulinos juntos (CANO, I981, p. 105). Outros fatores contribuíram para o retardamento da agricultura sulina, como a falta de uma política protecionista adequada à produção agrícola nacional; seu atraso tecnológico e os altos custos do transporte (Idem, p。I06)。

Além desses fatores, o próprio processo de concentração de capital na economia do extremo sü encontrava dificuldades, pois parte dos excedentes que gerava eram sugados 
e apropriados pelo grande comércio atacadista $(33)$ :

"... é possívei que uma parcela razoável do excedente gerado rela economia do extremo suI tenha sido apropriado pelo comércio atacadista localizado nos srandes centros urbanos do país (principalmente Rio e são PauIo), onde, já de lunga data, havia radicado seus interesses, sedes e operações. $(\ldots) "$ (CANO, 1981, p. 107)。

(33) As linhas gerais da economia no extremo sul, com as semeIhanças e diferenças entre os Estados que a compunham, podem ser apreendidas consultando-se CANO (1981, p. 107-115); FURTADO (1982, D. 144-149); PRADO JR., (1982, D. 219) ; CARDOSO (1962, p。66-70, 78, 81, 146-150, 179-186 e 234); SINGER (I968, p. 158-163); HOFF (I983, p. 21-36, $85-96$ e 108-117); IONBARDI (1985, p. 238-243)。 
5. A POLfTICA E A PRÁTICA INDIGENISTA DURANTE O PFŔ́DO MERCANTIL-ESCRAVISTA NACIONAI

Neste capítulo será tratado o indigenismo no transcorrer do período mercantil-escravista nacional. Primeiramente, caracterizar-se-á o indigenismo tendo em vista os interesses econômicos dominantes, que impunha o extermínio de grupos tribais por constituírem um empecilho ao desenvolvimento e por não se precisar mais de sua força de trabalho, sendo que para tanto foram criados todos os mecanismos que possibilitassem legal e praticamente a expropriação das terras indígenas. Na medida em que a estrutura produtiva não foi alterada sob as condições nacionais, continuando baseada no latifúndio, na monocultura e no trabalho escravo, a política indigenista correspondia a um continuísmo ideológico, nada mais restando que um indigenismo reacionário e anacrônico, que não via outra saída a não ser o extexmínio. A esta ideologia correspondia um aparato jurídico-formal que viabilizava o extermínio e a expropriação das terras indígenas. A caracterização da oolítica e da prática indigenista receberá um tratamento histórico, sempre correlacionado ao processo econômico. Nesse sentido, 
embora sejam indubitáveis as similaridades de situações que afetavam a região centro-oeste do país, será tratada, em separado, cada uma das duas Províncias que a formavam - Mato Grosso e Goiás - posto que interessa acomparhar a expansão da coIonização nessa região e como ela afetou diferentemente os diversos grupos tribais que aí tinham seu habitat.

\subsection{A Política e a Prática Indigenista no pe- ríodo mercantil-escravista brasileiro}

Em capitulo precedente do presente trabalho foi tratada a questão indígena durante o período colonial, observando-se que a política indigenista se desenvolveu de forma contraditória, de acordo com os interesses dos agentes da colonização metropolitana - jesuítas e colonos. Ainda que no plano legal essa contradição se manifestasse, é de se salientar que na prática em que se deram as relações entre índios e os agentes da colonização, a política indigenista correspondeu plenamente aos interesses dominantes durante o período: provocou o extermínio dos grupos tribais que impediam a implantação e efetivação da colonização; possibilitou a expropriação das terras indígenas necessárias à expansão da "civilização cristã ocidental"; finalmerte, forneceu, quando necessário, a força de trabalho cativa imprescindível à implantação da produção sob as bases impostas pelo capital mercantil.

Na medida em que a economia colonial se transforma quando de sua passagem para a economia mercantil-escravista nacional, a política indigenista também se transformará, correspondendo aos interesses econômicos que passam a ser dominantes. 
Neste quadro, os fundamentos econômicos passam a ser: de produção realizada sob condições nacionais - isto é, independente do "pacto comercial" e dos laços metrópole-colônia; de uma estrutura produtiva subordinada aos interesses do capital industrial, de tal forma que o capital se reproduzisse por relações de subordinação-dominação.

Correspondendo a esse quadro econômico, a política indigenista se submeteu aos interesses dominantes, assumindo novos traços: a contradição manifesta no plano legaI será eliminada, passando a corresponder de forme mais direta aos interesses da aristocracia agrária; efetiva-se o extermínio de grupos tribais, pelo duplo motivo de se constituírem em um empecilho ao desenvolvimento e de não serem mais necessários como força-de-trabalho cativo; finalmente, criam-se todos os instrumentos que possibilitam legal e praticamente a expropriação das terras indígenas

Assim, tratar da questão indígena, durante o período em estudo, significa necessariamente correlacioná-la à estrutura agrária do país. Como foi visto anteriormente, embora tenham sido mudados os fundamentos da economia brasileira, a forma da produção permaneceria inalterada sobre o tripé: latifúndio, monocultura, trabalho escravo. A essa ausência de modificações significativas da estrutura agrária, corresponderá uma política indigenista profundamente reacionária e anacrônica (MORERA NETO, 1971, p。xx)。Isso significa dizer que a política indigenista brasileira, mesmo sob conảições nacio-nais, nada mais foi que a continuidade da tradição colonial portugusa, no que se rếere às idéias fundarnentais que faziam sobre o índio brasileiro: um ser "bárbaro", "inferior", "impermeável ao desenvolvimento", nada maís restando fazer que o 
seu extermínio. Esse continuísmo ideológico é evidente, a ponto de não serem diferentes os argumentos brasileiros e portugrueses sobre a questão. Assim é que um texto portuguès de 1880, de autoria de Oliveira MARTINS, em nada se diferencia dos produzidos localmente, conforme se pode perceber pele. leitura do texto abaixo:

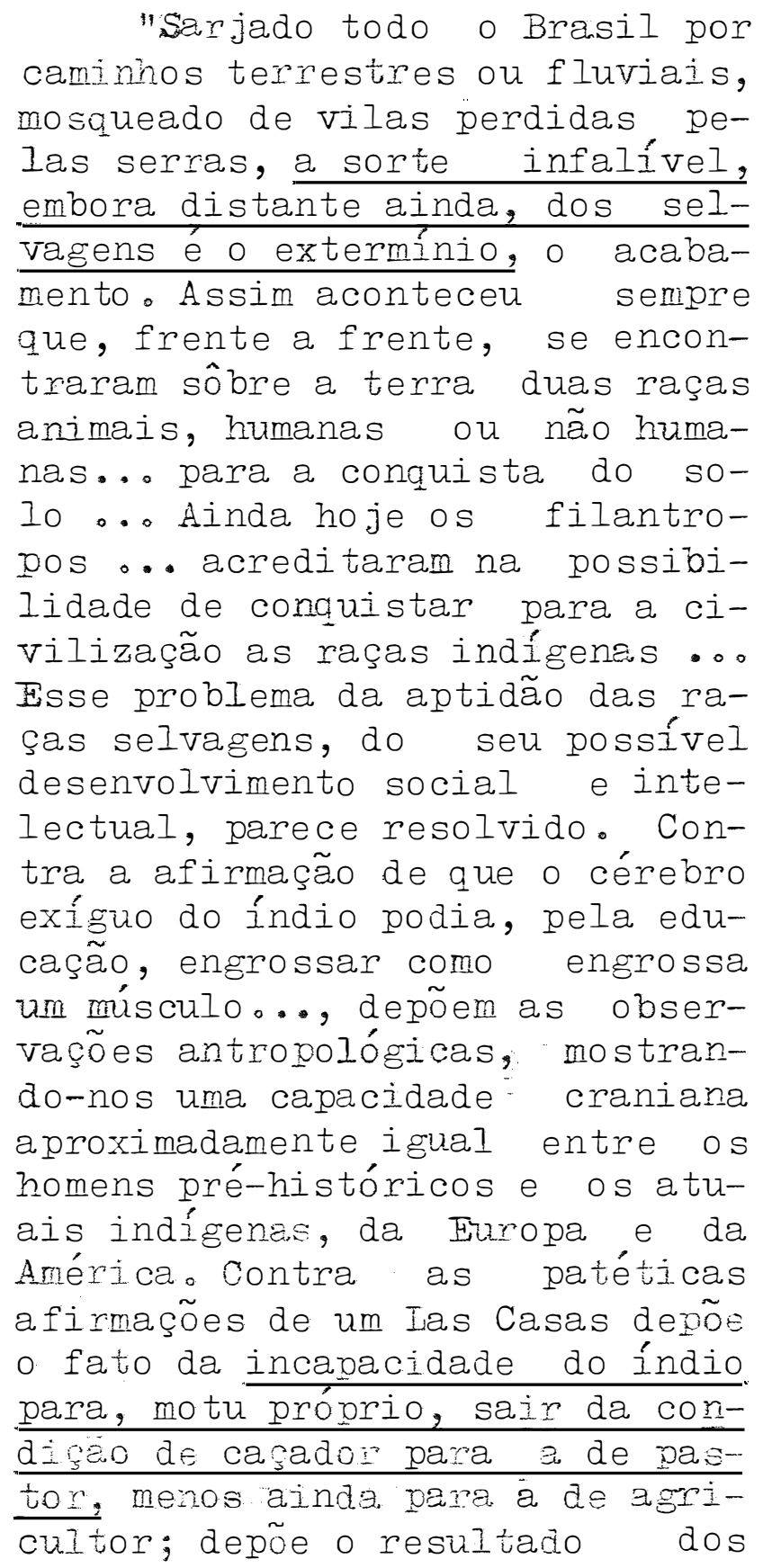


aldeamentos, estéreis experiências que levaram apenas, por um caminho diverso, à mesma escravidão necessária, predecessora de uma extinção fatal $\cdots$ Se indio tem a fala, e por isso é homem, o seu cérebro pesa pouco demais para poder atingir a eapacidade de raciocinar, refletir e ter consciência... Os diferentes tipos de homem formam una hierarquia, diferentemente dotada; e entre o índio antropófago, entre o homem que engorda filhos para os devorar e que os vende.. entre essas ínfimas raças humanas e os homens superiores, há diferenças tão essenciais como entre elas e os tipos mais elevados dos animais sem fala." (Apud MOREIRA NETO, 1971, p. xviii - os grifos são nossos)。

Outra não era a situação durante o período imperial, que buscou estabelecer a auto-identificação do país caracterizando-o como ração essencialmente européia por origem, cultura, organização político-institucional e, acima de tudo, por vocação e por destino (MORIIRA NETO, 1971, p. vii). Assim é que o regime monárquico e a presença no trono de um membro ligado pelo sangue e pela tradição às famílias reinantes da Buropa, legitimava a crença na excepcionalidade do caso brasileiro. Quanto à visão que se tem do índio, já é sobejamente conhecida a profunda influência que os ideólogos da te se da superioridade européia exerceram scbre o pensamento oficial brasileiro: VARNIAGM, profundamente influenoiado pelo con servadorismo ultramontano de De Maistre,justifica sua tese do emprego das forcas armadas contra os índios para obrigá-los a "civilizar-se" pelo trabalno cativo no exemplo da "cristianís- 
sima França" que se empenhava em "civilizar" a Argélia através da guerra e da anexação colonial:

"Longe de corderarmos o empreEo da força para civilizar os Índios é forçoso convir que não havia algum outro meio para isso. Nós mesmos; hoje em dia, havemos de recorrer a ele, quer em benefício do país aue necessita de braços, quer para desafrontar a disnidade humana, enversonhada de tanta desradação, quer finalmente a benefícios desses mesmos infelizes que, ainda quando reduzidos à condição dos africanos escravos na nossa sociedade, lograriam uma vida mais tranquila e segura, à que lhes proporciona a medonha e perigosa liberdade. de seus bosaues.

Empregue-se a suerra, se tanto for mister, para conseguirmos estes fins. Fm geral a Euerra tem sido um srande meio. civilizador entre os homens. Fremplo recente temos na Argélia suometida ao domínio civilizador da cristianíssima França" (Apud RIBEIRO, 1983, p. 83 - o grifo é nosso).

Vendo a questão mais profundamente, pode-se dizer que o Brasil independente continuará preso à mesma estrutura sócio-econômica, aos mesmos mecanismos de poder e à mesma visão de mundo que o caracterizaram durante o período colonial. Porém, com uma agravante, assumirá como própria uma ideologia aue é fundamentalmente européia e colonialista.

Evidentemente, os índios não permaneceram passivos. Enquanto no período colonial uma das alternativas que 
tinham era de uma resistência pacífica, através da constante e contínua fuga para os sertões indevassados; no período em que - Brasil se forma enquanto nação independente, essa alternativa ficou reduzida a muito poucos grupos, uma vez que as frentes de expansão da sociedade nacional tenderam continuamente a penetrar e ocupar todos os espaços passíveis de algum tipo de exploração.Aos índios, não restava outra alternativa que a resistência armada que eclodiu em todos os pontos do país, em praticamente todas as situações em que os índios eram obrigados a se relacionar com os "brancos". As formas que a resistência assumiu foram diferentes, sem dúvida, exprimindo-se quer sob a forma de rebeliões, como a Cabanagem e a Balaiada, por exemplo, quer sob a forma de movimentos messiânicos, como a "busca da terra sem males" dos Guarani e dos "cristos" do alto rio Negro; ou sob a forma de conflito generalizado entre os mais diversos grupos tribais e as frentes de expansão da sociedade nacional.

Como que "fantasma do passado" que vem nos incomodar no presente, em vários documentos do período as revoltas indígenas aparecem como provocadas pela "ação de agentes subversivos", ou como diriam na linguagem da época:

$$
\begin{aligned}
& \text { "(...) tratam de insinuar no es- } \\
& \text { pírito dos índios ideais subver- } \\
& \text { sivos, amorais e contrários ao } \\
& \text { pensamento do Governo Imperial } \\
& \text { ‥" (Carneiro da CUNHA, a } \\
& \text { MOREIRA METO, 1971, p. I20). }
\end{aligned}
$$

Essa explicação não é particular a uma determinada situação, mas foi dada para justificar vários dos movimentos: a Cabanagem foi provocada pelo incitamento do ânimo dos índios e "tapuias" contra a população civilizada, por ele- 
mentos contrários ao regime e à ordem pública, ou que procuravam em benefício próprio capitalizar essas tensões e conflitos; o movimento dos "cristos" no alto rio Negro, tanto no século XVIII quanto no XIX, foi atribuída a elementos estranhos a essas comunidades, que se infiltravam no meio dos índios para provocar revolta contra os interesses portugueses (no século XVIII) e, mais tarde, contra os interesses do Império (no século XIX); a revolta de Ajuricaba, durante o século X.. XVIII, foi atribuída à instigação de agentes holandeses; os vários incidentes ocorridos depois da Cabanagem, no alto rio Negro, foram atribuídos a missionários ou agitadores a serviço dos interesses britânicos (MOREIRA NETO, 1971, p。120-121)。

Essa problemática foi tão elaborada por "intelectuais do Império" a ponto de, em meados do século, VARNHAGEN referir-se aos grupos indígenas hostis ou aos diversos conflitos entre índios e colonos como "rebelião armada dentro do Império".

Antes de mais nada, é interessante que se retome as linhas gerais que marcaram a politica indigenista nas últimas décadas do período de crise da economia colonial. e, consequentemente, das transformaçöes que passam a ocorrer no seio da mesma, gestando as condiçŏes para o período subsequente - da economia mercantil-escravista nacional.

Anteriormente se viu que a administração pombalina ( 1750 a 1777) esteve envolvida numa eficaz política diplomática e militar destinada à consolidação, legalizaçã e o cupação portuguesa das áreas que eram objeto de disputa com outros Estados coloniais europeus, principalmente a bacia do rio da Prata, o extremo Oeste e Norte (RIBEIRO, 1983, p.83)。 
Neste quadro, a utilização do índio passou a ser imprescindível sob dupla situação: do ponto de vista militar, como "aliados" dispostos a colaborar com os portueueses contra os espanhóis, ingleses, holandeses e franceses, ou em último caso neutralizá-los para não serem inimigos dos portugueses; do ponto de vista político-econômico, como partes ativas do processo de colonização desencadeado por Portugal, evidenciando a ocupação de fato das regiões reivindicadas pela Coroa metropolitana. A legislação pombalina era, nesse sentido, reflexo da política mais geral adotada por Portugal em vista de seus objetivos imediatos: extingue o cativeiro dos índios, tornando-os "súditos" do rei de Portugal - em 1755; cria o Diretório dos Indios e eleva as aldeias a vilas, transformando a atuação indigenista em frentes de ocupação e colonização - em 1757; finalmente, expulsa os missionários jesuítas em 1759, ficando Portugal com o poder temporal e espiritual sobre os índios nos territórios da colônia sul-americana.

Como já se salientou, a política indigenista de Pombal teve um suciesso aparente, embora suficiente para os objetivos a que se propurha, sendo suas pseudo-transformações puramerıte formais e circunstanciais.

Tão logo se consolidaram as fronteiras durante - período pombalino, a política indigenista volta a adotar, no plano legal e prático, uma forma progressivamente anti-indigenista, restabelecendo as permissões formais e os incentivos para a escravização dos índios, para o seu extermínio e para a "desinfecção" de sues terras.

Assim, o período da Regencia e, posteriormente, do reinado de D. João VI, foi uma época de franca ação repressiva contra os ináigenas, desenvolverido-se verdadeiras campanhas militares contra os grupos tribais considerados "irredu- 
tíveis" ou "incivilizáveis". A documentação da época (34) é reveladora do ódio e violência em relação aos índios, concretizados em atos injustificáveis como a contaminação intensional dos indígenas por moléstias contagiosas (MOREIRA NETO, 1971, Parte I). Esse caráter progressivamente anti-indigenista, que marcou a prática e a política indigenista pós-pombalina, tinha por meta o alargamento da colonização, permitindo a ocupação das áreas habłtadas por indígenas。

Reflexo.disso tem-se no instrumento legal do período: a Carta Régia de 1798. Por trás dos objetivos explícitos de "integração do índio à sociedade colonial", as instruçoes dirigiram-se para objetivos mais práticos e concretos: - aproveitamento dos indígenas como força de trabalho cativo; - extermínio dos grupos que dificultavam a colonização; expropriação do patrimônio indígena, notadamente a terra.

o primeiro aspecto fica claro quando a legislação dispõe sobre a organização dos índios em corpos de trabaIhadores, estabelecendo-se que durante determinado número de anos deveriam servir obrigatoriamente. Vai mais longe, determinando que os índios que não possuíssem estabelecimento próprio e não tivessem ocupação fixa, fossem compelidos ao trabaIho público e particular.

A "guerra ofensiva" aos índios ficou proibida nesse dispositivo legal; porém, propõe a adoção de um sistema "defensivo", que passou a ser usado da mesma forma que o uso

(34) Para melhor conhecer e conteúdo ideológico contido na documentação produzida durante o período compreendido entre 1777 e 1808, é interessante consultar a tese de doutoramento de MOREIRA NETO (1971, Parte I). 
da força, servindo para o extermínio de todos os grupos indígenas que impedissem o avanço das frentes de expansão。

Finalmente, ficava livre o comércio com os índios, passando a ser aberto para todos; ficava também livre a exploração dos recursos naturais em terras indígenas, bem como a ocupação de terras por lavradores brancos. Tal medida significou a condenação dos aldeamentos indígenas ao desaparecimento; isto era tão intencional que a própria lei previa que todos os bens dessas aldeias fossem vendidos e os resultados obtidos, recolhidos aos tesouros das províncias (MOREIRA NETO, 1971, p. 334-335).

Considerando-se essa legislação indígena em si mesma, não há dúvida de ser dura e coercitiva em relação aos índios; porém, o período posterior, compreendido desde a vinda da família real para o Brasil, até a Independência, será infinitamente mais drástico em suas soluções da questão indígena brasileira。

A transferência do poder real intensificou de forma radical o caráter das leis repressivas contra os índios. A causa básica, sem dúvida, encontra-se no incremento populacional, notadamente da nobreza imigrada que passa a ocupar as áreas litorâneas, forçando a expansão da colonização para novas regiões. Dessa forma, os últimos bolsões da floresta atlântica, ocupados por poprlações tribais que haviam conseguido sobreviver à devassa colonial, passam a ser metódica e progressivamente invadidos. Os conflitos foram se multiplicando, acompanhando os rumos seguidos pela expansão econômica (RIBEIRO, 1983, p。82).

Inicialmente, a ocupação afetou aos Botocudos de Minas Gerais, sendo que a legislação de 1808 passa a conter 
os elementos básicos da nova política indigenista: na Carta Régia de 13 de maio de 1808, é declarada "guerra ofensiva" contra os Botocudos, habitantes de Minas Gerais, e aos prisioneiros restabelece-se o cativeiro. A ideologia utilizada para justificar esse extermínio e escravidão, reprisa os argumentos que eram usados desde o século XVI, conforme se pọde evidenciar pela leitura do trecho abaixo da Carta Régia:

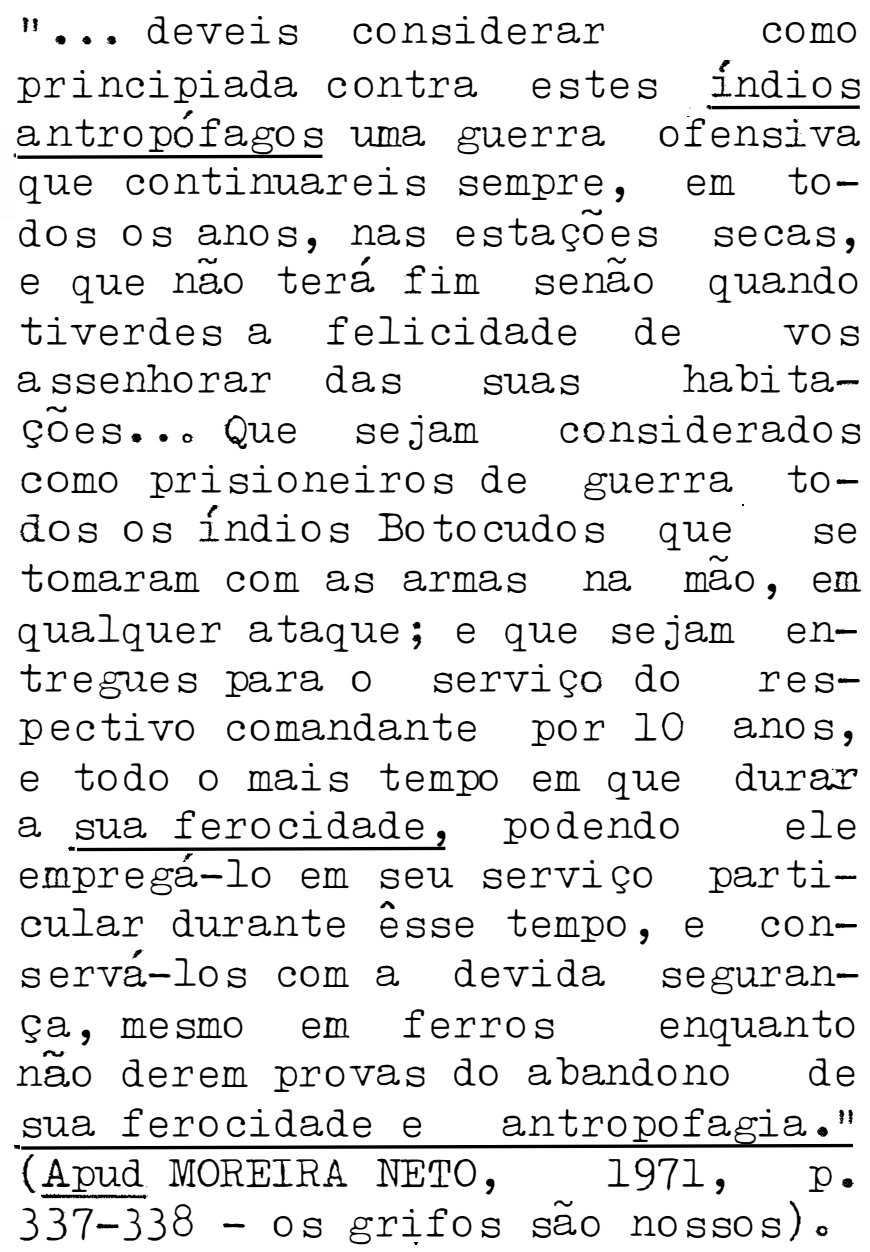

No mesmo ano, ordena a mesma providência contra os Kaingang de são Paulo, com a inovação de que todo miliciano. ou particular que prendesse algum índio poderia considerá-lo como "prisioneiro de guerra" por 15 anos, podendo destiná-lo ao serviço que quisesse.

Em 1809, reitera as normas para a campanha con- 
tra os Botocudos de Minas Gerais, porém com alguns novos elementos: tenta regulamentar as ações oficiais e particulares contra os índios, recuperando as já conhecidas bandeiras, que deverão ser autorizadas pelo comandante militar da província; explicita a condição de cativos ou escravos aos "prisioneiros de guerra", pelo prazo de 15 anos; reserva aos religiosos, que passam a acompanhar todas as bandeiras, o papel de ratificarem a condição de escravos aos índios aprisionados (MOREIRA NETO, 1971 , p. 338 ; MELATTI; 1980, p. 187).

Os objetivos dessas ações ficam claramerte explicitados no transcorrer de 1809, quando através de Carta Régia (13 de julho de 1809), ordena-se que as áreas "antigamerte ocupadas pelos Botocudos":

"... se fossem logo distribuindo sesmarias aos novos colonos que entrassem, na tentativa de os povoar, e cultivar, como o principal objeto das saudáveis providências que já tinha ordenado e continuaria a dar em benefício dos Povos dessa Capitania..." (Apud MOREIRA NETO, 197Z; p. 340)。

Ainda durante o período de permanência da família real, já se verificavam os esforços de colonização de grandes áreas do interior do paíso Exemplo disto, é dado pela Carta Régia de 05 de setembro de 1811 atingindo as Províncias do Pará e Goiás,em que é autorizada a implantação de navegação regular ao longo do rio Tocantins; estabelecimento de colônias ao longo do rio; e para os índios que dificultarem a colonização, a concessão dos mesmos "privilégios" dados aos colonizadores de Minas Gerais: guerras ofensivas e escravização pelo prazo de 15 anos, ou pelo tempo necessário à "domesticação" 
dos índios. Nesse sentido, este documento trata nominalmente dos seguintes grupos tribais, considerados "não civilizáveis" e então habitantes da bacia do Tocantins: "Apinagé, Chavante, Cherente e Canoeiro.o"

Resumindo a política e a prática indigenista nesta fase, tome-se de empréstimo a análise do autor de A PoIítica Indigenista Brasileira Durante o Século XIX:

"(...) A tônica da política indígena de D. João VI é a repressão, aplicada como regra a todos os setores da vida indígena. Ao lado disso, há um esforço continuado e consequente para a desorganização e eventual dissolução dos aldeamentos e comunidades indígenas, principiando por alienar-lhes a base, isto é, os territórios em que se mantêm, (...)" (INOREIRA NETO, 1971, p. 3<2-343).

Independente o Brasil de Portigal, continuaria preso ̀̀ mesma estrutura social, econômica, política e ideológi ca que caracterizou o período colonial, como já se disse. Assim, a independência do Brasil manteve inalteradas as regras re ferentes àregulamentação das celações entre índios e brancos。

Deve-se observar, porém, que vários foram os projetos que procuraram implementar uma política indigenista que visasse o bem-estar dos índios do Brasil, entre os quais figuram os elaborados por: Francisco Muniz Tavares, de Pernambuco; Domingos Borges de Barros, da Bahia; Francisco Ricardo Zane e José Caetano Ribeiro da Cunha, do Pará; e José Bonifácìo de Andrada e Silva, de São Paulo. Entre estes ficou conhecido o projeto elaborado por José Bonifácio e encaminhado à Assembléia Constitucional do Brasil, de 1823。 
seus "Apontamentos para a Civilização dos Indios do Brasil", BONIFACIO apresentou os princípios que considerava básicos para uma política indigenista:

"Iㅇ) Justiça- não esbulhando mais os índios, pela força, das terras que ainda thes restam e de que são legítimos senhores; 2o) Brandura, constầncia e sofrimento de nossa parte, que nos cumpre como a usurpadores e cristãos;

30) Abrir comércio com os bárbaros, ainda que seja com perda de nossa parte;

4ㅇ) Procurar com dádivas e admoestações fazer pazes com os índios inimigos;

50) Favorecer por todos os meios possíveis os matrimônios entre índios e brancos e mulatos ." (Apud RIBEIRO, 1983, p。82)。

Nenhum dos projetos, porém, acabou incorporado à primeira Constituição Brasileira, de 1824, o que indica o prevalecimento dos interesses básicos dos grandes proprietários fundiários do país, indiscutivelmente a classe dominante. Estes impuseram, assim, a continuidade dos velhos metódos indigenistas do período colonial, sendo que:

"Em 1825, estavam em plena atividade as bandeiras e outras medidas repressivas contra índios..." (MOREIRA NETO, 197I, p. 357).

Em 1825 já era declarada guerra contra os índios de Goiás, ao mesmo tempo em que o Ministério da Marinha aprovava a criação de uma companhia de índios para o arsenal da marinha do Maranhão e dos navios da armada, engajados de 
forma coercitiva. Em 1826, a Mesa do Desembargo do Paço analí sa a restituição ou não das terras dos índios da Província do Rio Grande do Norte, decidindo pela garantia de posse das terras aos agricultores que as invadiram legitimando, dessa forma, o esbulho das terras indígenas. O último ato do primeiro império, em 1ㅇ de março de 1830, foi dado pelo Ministério da Justiça, ao declarar que os índios deviam ser governados pela legislação geral, eliminando-se, assim, o protecionismo que, malgrado a prática indigenista agressiva e violenta, contribuía para a defesa de seu patrimônio coletivo.

Durante o período regencial (de 1831 a 1840), houve um resfriamento da política indigenista agressiva em relação aos índios, pelo menos no plano legal. Assim, logo após a abdicação ae $D$. Pedro I, foram revogadas as Cartas Régias que mandaram fazer guerra e pôr em servidão os índios。 Nessa mesma lei os índios são equiparados aos órfãos, ficando os Juízes de Orfãos seus tutores e administradores de seus bens (MELATTI, 1980, p。187). No plano da prática indigenista, porém, os conflitos ènvolvendo os índios e as frentes de expanção nacional continuaram por toda essa década, sendo que essa situação de conflito estava generalizada por todo o território nacional, conforme evidenciam os documentos da época. (35)

A título de exemplo, veja-se o ocorrido em 1835 envolvendo os índios da Província de Goiás: estavam em estado de conflito permanente com colonos na região do Vale do Tocantins; essa permanente hostilidade trouxe como contrapartida a

(35) Seria demasiadamente longa a referência documental sobre os conflitos da década de 1830-40, os interessados no assunto poderão consultar MOREIRA NETO (I97I, Parte I)。 
organização de bandeiras particulares, sustentadas por incentivos e verbas públicas. Após as primeiras ações contra os Xerente, estes fizeram, em represália, alguns ataques ne região. Várias expedições foram organizadas, com resultaāos nulos até que, finalmente, a Câmara Municipal de Porto riscional decidiu e aprovou a liberação de recursos para uma "ežedição mais poderosa".

As expedições periódicas contra os Xerezte, Xavante e Canoeiro, agravavam a cada dia os conflitos, zié que em 1838 decidiu-se pela organização de uma grande bz-deira, organizada pelo Governo da Província, contra esses gruzos tribais, conforme consta de relatório do Presidente da Província de Goiás, Padua FLEURY:

"Terrível aspecto têm apresentado os indígenas Canoeiros, Chavante e Cherente depois das expedições que em 1836 . E-charam contra êstes selvagens $€$ que em vez de os abater, só serriu para mais os alentar em suas rostilidades. ... Causa dôr, e não é possível ouvir-se tão horrorosos fatos sem estremecer-se; parece que estas três Nações tễ projetado acabar com os povo rolina, Porto Imperial, Tatividade, e Amaro Leite; nenima segurança, e quase nenhume esperança há para estes deszaçados habitantes, em parte cause eles mesmos dos males que ioje sofrem. O Govêrno da Prcvíncia conseguiu levantar um corpo de 271 praças para atacar o Chavante e Cherente; a desuniãc dos Chefes, a insubordinação dos Praças, e principalmente $c$ pouco interesse, que cada um tomava 
pelo bom êxito da expedição, fez que se frustrasse tão aparatosa e dispendiosa Bandeira, que só serviu para gravar a Província com essa infrutífera despesa, e dar ao selvagem uma idéia bem desvantajosa de nossa coragem." (Apud MOREIRA NETO, 1971, p。 192-193)。

Durante o Segundo Império, a legislação indigenista foi, em termos formais, mais liberal em relação aos períodos anteriores; porém, continuaram em operação os velhos mecanismos descriminatórios contra os índios e as mesmas relações de dominação no setor agrário, que tornavam os dispositivos legais desse período inoperantes.

No transcorrer da década de 1840 se estabeleceram as bases legais do indigenismo durante o Império, que perduraram até a República. Inicialmente, em 1843 o governo autorizou a vinda de missionários capuchinhos e tomou as providências para distribuí-los pelas Províncias, em missões (NELTATTI, 1980, p. 187). As medidas legais que seguiram a esta tomada de posição, acabaram por dar a esses missionários uma posição de virtual controle sobre a política indigenista do Império, não somente no que se refere à atividade missionária, como também à própria execução e direção das medidas de cunho oficial em relação aos índios. Porém, a atividade missionária dos capuchinhos, ao longo do período, deixou a marca de uma sucessão de fracassos e erros cometidos pelos seus missionários. Vários são os motivos imputados ao fracasso da obra missionária dos capuchinhos: o reduzido número de missionários para uma tarefa da amplitude do território brasileiro; unido a isto estava a falta de preparo às condições culturais e sócio-econômicas em que deveriam trabalhar; a fragilidade dos re- 
cursos postos a sua disposição pelo governo; a orientação básica imposta pela política indigenista, que, em última análise, não adotava medidas de longo alcance em benefício dessas populações; as contínuas pressões da população regional, que criariam sérios entraves para a missão。

Através da lei no 317, de 1843, o Legislativo autorizou o governo a estabelecer as normas políticas indigenistas, reunindo e metodizando a legislação dispersa sobre indígenas. O assim disposto foi promulgado em 1845, pelo decreto no 426. As disposições básicas deste decreto, denominado "Regimento das Missões", já foram sintetizadas anteriormente.

Observa acertadamente MOREIRA NETO ( 1971, p. 371 e s.) que a leitura da síntese do decreto pode levar a tomar a lei por um "instituto benigno, destinado a proteger e a estabelecer um mínimo de garantias..." (p. 371), quando a mesma possibilita, por uma série de dispositivos, um perigo para o destino das populações indígenas. Vejam-se as observações que são feitas a esse respeito:

"(...) o $\$ 20^{\circ}$ do art. lo, por
exemplo, declara que cabe ao Di-
retor Geral dos fndios indagar
os recursos que oferecem para a
lavoura e comércio, os lugares
que estão colocadas as aldeias;
e informar ao Gołêrno Imperial
sôbre a conveniência de sua con-
servação ou remoção, ou reunião
de duas, ou mais, em uma só. o $\S$
3o diz que se aconselhada a re-
moção dos índios, esta deve fa-
zer-se sem violênia. Natural-
mente, a violência maior está na
admissão do esbulho das terras
indígenas por quaisquer razões
que ocorram à mente do Diretor


Geral, tanto mais que o $\S 4 ㅇ$ do mesmo art. atribui ao mesmo funcionário a tarefa de indicar ao Govêrno o destino que se deva dar às terras que forem abandonadas espontâneamente pelos índios ou desocupadas por efeito do disposto no $\S$ acima citado. Ao mesmo Diretor Geral, segundo os $\S \S 80$ e 1 llo do mesmo art。, compete, também a decisão sôbre transferência de populações indígenas inteiras e o estabelecimento dos modos e critérios de demarcação das terras indígenas. Além disso, no $\S 12$ ㅇ se diz que ao Diretor Geral dos Indios cabe ' examinar quais são as aldeias que precisam ser animadas com plantação em comm e determinar a porção de terras que deve ficar reservada para essas plantações, assim como a porção das que possam ser arrendadas quando ... não possam os Indios aproveitá-las todas'. (...)

Um dos dispositivos mais danosos para a conservação e desenvolvimento das comunidades indígenas é $0 \underset{\sim}{\S} 150$ do mesmo art., que dispõe 0 seguinte: "Informar ao Govêrno Imperial acêrca daquêles índios que, por seu bom comportamento e desenvolvimento industrial, mereçam se thes concedam terras separadas das da aldeia, para suas grangearias particulares....' 0 disposto nesse parágrafo constitui em elemento essencial à desagregação da vida comunal do grupo, estimulando índios mais ambiciosos ou mais afeitos ao trato com a sociedade nacional a 
afastar-se da comunidade e desenvolver junto a ela uma vida puramente individual... outro elemento extremamente danoso ao bem-estar e à sorte dessas populações é a permanência da tradição colonial do recrutamento de Índios para obras públicas. (...)" (MOREIRA NETO, 1971, p. 371-372).

Vista em seu aspecto mais amplo, esta legislação indigenista, promulgada no início do Segundo Império, nada mais estava fazendo que acompanhando o desenvolvimento da economia mercantil-escravista nacional, exatamente no momento de sua consolidação, possibilitando a liberação das terras "que iam sendo ocupadas pelas lavouras, qualquer que fosse a frente de expansão, notadamente o café, ao mesmo tempo em que deveria possibilitar a liberação dos escravos negros para as grandes lavouras, utilizando nas obras públicas o trabalho de índios, recrutados para tal fim.

Os reflexos dessa situação alcançaram todas as regiões do país. E para que fique mais clara, tanto em relação à terra quanto ao trabalho dos índios, note-se como isto se refletiu na expansão que se verificava pelo Tocantins e Araguaia, pela frente de colonização realizada através da criação de gado.

Após o período marcado por agressões contra os índios considerados como "não civilizáveis", que perduraram até 1846, passam-se a adotar novas técnicas, com o estabelecimento de Aldeias nos lugares mais frequentemente habitados pelos índios ao longo dos rios Tocantins e Araguaia, assim vista pelo Presidente da Província Pádua FleURY, em 1848:

"... em não deslocá-Ios dos lu- 
gares em que êles têm adquirido seus hábitos e costumes, mas fazendo-lhes gozar aí mesmo dos cômodos que a sociedade oferece, ensinando-Ihes ao mesmo passo os princípios e as verdades do cristianismo. ..." (FLEURY, apud MOREIRA NETO, 1971, p。206)。

Mas essa proposta do governo de Goiás, na pratica, se frustava, pois, ao longo da década de 1840, a ação dos criadores de gado e proprietários de terras nas regiões que iam sendo abertas à colonização, forçavam o deslocamento de vários grupos indígenas de suas áreas de ocupação imemorial, sob o argumento de que essas terras eram essenciais ao progresso da colonização.

Assim, no mesmo relatório em que o Presidente da Província, Pádua Fleury, advogava por uma política de aparente defesa dos índios e de suas terras, relata a transferência dos índios Krahô, aldeados nas margens do rio Farinha, transferindo-os para o rio do Sono, graças aos argumentos de Frei Raphael de Taggia, expressão direta e sem disfarces dos interesses dos colonos da região. Com a transferência ficava viabilizada a construção da estrada de Porto Imperial a Carolina, e a navegação receberia socorros desta aldeia (Apud MOREIRA NETO, 1971, p. 208-209).

Quanto à utilização da mão-de-obra indígena, essa situação ficou muito mais clara um ano depois - 1849 - quando - novo presidente da Província de Goiás, Eduardo Olympio Macha do, advogou pela utilização da força de trabalho indígena, face à eminente abolição da escravidão do negro e da impossibilidade de imigração de colonos europeus (MACHADO, apud MOREIRA NETO, 1971, p. 212). 
o principal ato, porém, da tendência de possibilitar as condições para a expansão e o desenvolvimento da coIonização, foi dado logo a seguir, com a Lei no 601, de 18 de setembro de 1850 - a "Lei de Terras" - vista quando se tratou da economia mercantil-escravista nacional - e que afetou profundamente os grupos tribais que se encontravam nas áreas próximas à colonização.

A "Lei de Terras" de 1850 dividiu as terras em duas categorias: as "terras públicas", que pertenciam ao Estado; e as "terras particulares", provenientes de um título legítimo de propriedade ou de uma simples posse legalizada (MEIATII, 1980, p. 188). Todas as terras devolutas só poderiam ser apropriadas mediante a compra e venda, sendo que o governo destinaria os rendimentos dessas transaçoes para financiar a vinda de trabalhadores imigrantes europeus. Essa medida legal pretendia solucionar, como se viu, dois problemas: a questão do acesso à terra, restringindo apenas àqueles que dispusessem de capital para poder adquiri-las; e criava as bases para a organização de um mercado de träbalho livre que substituisse o sistema escravista (SILVA, i982, p. 24-25).

As terras expressamente concedidas aos índios foram consideradas por esta lei como "terras particulares", devendo, portanto, serem regularizadas junto aos órgãos competentes. Essa disposição não podia ter sido mais nefasta aos índios:

"(...) Tal providência foi prejudicial aos indígenas, pois, não estando em condições de saber o que fazer para promover as medidas necessárias a fim de assegurarem a consolidação de seus direitos, segundo a Lei, acaba- 
ram, em muitos casos, perdendo - direito que a elas tinham para - que colaborou também a astúcia e má fé de seus vizinhos。(...)" (NEIATTI, 1980, p. 188)。

Para os indígenas, que ainda não estavam aldeados, a lei estabelecia que nas terras pertencentes ao Estado deveriam ser reservadas áreas para a colonização indígena. No art. Io, afirmava-se o direito do índio ao território de suas aldeias. No art. 120, determinava que o Governo reservasse das terras consideradas "devolutas" as que julgasse necessárias para a colonização dos indígenas, para a fundação de povoações, aberturas de estradas... e assento de estabelecimentos públicos. Em seu art. 14으, autorizava o Governo a vender as "terras devolutas", em hasta pública e como julgasse mais conveniente.

$\mathrm{Na}$ medida em que parte das terras indígenas foram enquadradas nas "terras devolutas", a combinação destes dois dispositivos legais foi funesta para grande número de aldeamentos indígenas existentes em áreas próximas à expansão econômica, ou naquelas províncias densamente povoadas, como o Nordeste. Desta forma,

"... as aldeias assim criadas foram abandonadas, caíram no domínio público e acabaram sendo cedidas em locação a particulares." (NELATTI, 1980, p.188)。

A "Lei de Terras", seguiram-se quase que imediatamente, outros instrumentos legais que tinham como objetivo explícito regulamentar as terras indígenas. Assim, um mês depois de aprovada a Lei no 601, é divalgada uma decisão do Ministério do Império, ordenando a incorporação das terras dos índios que já não viviam aldeados, mas dispersos e confundidos 
na massa da população civilizada. Em 30 de janeiro de 1854, o decreto no 1318, manda executar a "Lei de Terra", de forma a facilitar a transferência de terras públicas ou devolutas para o domínio privado, através de atos jurídicos que promovessem o pleno direito de propriedade privada sobre as mesmas.

Como se disse acima, uma verdadeira avalanche contra as terras indígenas passa a ser executada. Essas situações se deram, principalmente, nas frentes de expansão econômica que tinham por base de exploração econômica da terra, como em toda a região cafeeira, nas frentes de expansão pastoril do centro-oeste, e na economia nordestina.

Importa deter-se neste processo de expropriação de terras indígenas, a fim de verificar como isto se deu em algumas regiões.

No Ceará, em 18 de dezembro de 1852, uma declaração do presidente do "Tribunal do Tesouro Nacional" ao "Procurador Fiscal da Tesouraria da Província do Ceará", deu encaminhamento à liquidação de aldeamentos naquela província, conforme se pode ver pelo trecho abaixo:

"... Declara para sua inteligência que se deverá tomar posse das terras das extintas aldeias dos índios de Arrenches e Mecejana, em execução das sentenças que, por copia, acompanharam aquele Ofício, não lançando-as nem inscrevendo-as no Livro dos Próprios por não pertencerem à classe dêstes, devendo ser consideradas como Bens Nacionais devolutos para serem aproveitadas na forma da lei de lo de setembro de 1850..." (Apud MOREIRA NETO, 1971, p. 374-375)。 
É interessante verificar as razões alegadas para a extinção dos aldeamentos, que sob o argumento de que a população indígena residente já estava "integrada" na sociedade regional, nada mais se fazia que a expropriação das terras indígenas, que eram vendidas ou concedidas aos grandes latifundiários. Essa situação pode ser apreciada pelo relatório do Presidente da Província de Pernambuco à Assembléia, em 1868:

"O aldeamento da Escada foi extinto porque os poucos índios que ali habitavam achavam-se já confundidos na massa geral da população, e por isso determinei que se desse a cada. um daquêles que quizessem estabelecer-se nas terras do riacho do Mato, que o govêrno Imperial concedeu para serem distribuidas pelos mesmos índios, um lote de 22.500 braças quadradas, respeitada a disposição do art。 Iㅇ, $\S 3$ 을 do decreto no 426, de 22 de julho de 1845 . ( ...) Julgo conveniente que, conservando-se da légua de terras da Escada concedida ao aldeamento, o terreno em que está edificada a Vila, para patrimônio da respectiva Câmara Mrunicipal, se proceda à venda do restante pela forma que o govêrno julgar mais conveniente." (VILA-BELA, apud MOREIRA NETO, 1971, p. 306-307)。

Relatos como esse pontilham a documentação da segunda metade do século XIX, atingindo as regiões em que a exploração econômica fundava-se na exploração da terra, agora dotada de valor de troca, dada sua caracterização enquanto "propriedade privada".

No que se refere ao uso da força de trabalho indígena, continuavam a vigorar as disposições de 1845 sobre a 
utilização compulsória de índios para o serviço público e tratada anteriormente. É interessante observar, porém, que outras medidas passaram a ser exigidas com vistas a diminuir os efeitos provocados pela necessidade de mão-de-obra escrava imposta pelo desenvolvimento da economia cafeeira e que são supridas pela migração de escravos negros do norte e nordeste. Na medida em que a força de trabalho escravo começa a ser sugada pela economia cafeeira, os agentes da exploração econômica nas zonas afetadas começam a reutilizar o indígena, como força de trabalho. Essa situação, fica perfeitamente nítica pela leitura do Aviso de 02 de janeiro de 1854, dirigido pelo Ministério do Império ao presidente da Província do Maranhão, Iruiz Pedrei ra do Couto Ferraz, através do qual se responde afirmativamente à consulta de se era permitivo o recrutamento compulsório de índios para o trabalho público ou particular. Assim, dispôs - aviso, após conceder o recrutamento compulsório:

"... solicitando a faculdade de mandarem buscar às aldeias índios de tôdas as idades e sexos, que voluntariamente quisessem ir para os seus estabelecimentos, obrigando-se: 1ㅇ - a sustenta-los, vestí-los e tratá-los por três anos, sem mais retribuição alguma pelo seu trabalho; $20-a$ pagar anualmente, findo os três anos $25 \$ 000$ por cada índio maior de 18 anos, e $15 \$ 000$ a índias maiores de 16 anos, além do sustento, vestuário e tratamentos nas enfermidades; 30 - a franquear os seus estabelecimentos ao agente que o Govêrno encarregar da fiscalização do cumprimento do contrato... cuja proposta julga $V$. Exa. que pode ser favoravelmente deferida ..." (Apud MOREIRA NETO, 1971, p。 


\section{$375)$.}

A legislação indigenista posterior não acrescenta praticamente nada aos atos oficiais aprovados ou outorgados no transcorrer da década de 1850. Embora a ênfase da política indigenista, sob seu aspecto legal, passe a ser com relação à terra e à utilização da mão-de-obra indígena, outros aspectos importantes continuaram marcando a prática indigenista durante - período, como: a continuação dos descimentos forçados de índios para aldeamentos missionários ou militares, como os verificados no Pará e no Amazonaś; a continuação dos confīitos entre índios e agentes das frentes de expansão, que se verificavam em praticamente todas as regiões do país, notadamente no Pará, Amazonas e Maranhão, Mato Grosso e Goiás. Ceará e Alagoas, São Paulo, Paraná e Santa Catarina; continuação da prática de extermínio de grupos tribais, quer sob a forma de institucionalização de caçadores profissionais de índios, os "bugreiros", ou de envenenamentos de aguadas e transmissão propositada de moléstias infecto-contagiosas, em sua maioria fatais aos índios - situação que se verificava nò Maranhão, no Amazonas, no Mato Grosso, em Goiás, em São Paulo, no Paraná e em Santa Catarina; finalmente o uso de grupos indígenas para o extermínio ou neutralização de outros grupos tribais, como ainda se verificava no Mato Grosso e em Goiás.

Da mesma maneira que a rolitica indisenista foi se transformendo historicamente, acompanhando as metamorfoses que se verificavam na instância econômica (isto é, acompanhando os rumos seguidos pelo cápital), a política e a prática indigenista também se adequavam diferentemente às diversas economias regionais. 
Desnecessário dizer da complexidade desta problemática, sendo que o melhor caminho a seguir é ir tratando da questão por partes. E inquestionável que as transformações ocorridas ao longo do final do século XVIII e no transcorrer de todo o século XIX, quer à nível econômico, quanto político-jurídico e ideológico, tinham como centro dominante a economia cafeeira, aqui denominada de "economia mercantil-escravista cafeeira nacional". Porém, não se pode entender plenamente este período histórico e a questão em pauta, se não se levar em consideração o que acontecia nas diferentes regiões, do país, e, notadamente, nas diversas economias regionais, que por sua própria situação estavam subordinadas aos interesses maiores da economia mercantil. Assim, deve-se verificar como se comportou a política indigenista face às economias regionais: 1) a amazônica, com sua exploração extrativista;2) a nordestina, com sua gradativa decadência; 3) o extremo-sul do país, com sua economia de subsistência; 4) a região leste-central (Espírito Santo, Minas Gerais e Sul da Bahia), com a expansão agrícola; 5) finalmente, a região cafeeira. Devido aos objetivos dó presente trabalho, a região centro-oeste (Goiás e Mato Grosso), será estudada separadamente.

Desde o período colonial, o vale amazônico teve sua base econômica na exploração de produtos florestais, produzidos graças à utilização do trabalho indígena.

Entre meados do século XVIII, até as primeiras décadas do século XIX, a economia amazônica ainda estava baseada na exploração das drogas do sertão. No que se refere aos índios, este período foi marcado pela substituição das missões pelo regime de Diretorias de Indios, criado pelo Marquês de Pombal. Essa mudança, muito embora a legislação protecionista 
então vigente, não melhorou a situação da população indígena do vale, mas, pelo contrário, agravou-a com a intensificação do recrutamento "à força d'armas" da mão-de-obra indígena necessária não somente para a coleta dos produtos florestais, como para outros empreendimentos mercantis do Estado, como os projetos de cultivos agrícolas para exportação a Belém e à metrópole (cacau, café, cana-de-açúcar, algodão e anil); depois, pela introdução do gado. Além disso, para a consolidação das fronteiras foram construídos fortes em várias localidades, recrutando-se, para tanto, o trabalho indígena (RIBEIRO, 1983, p. 68).

Dentro dessas condições, as populações indígenas do antigo Estado do Maranhão (Maranhão, Pará e Amazonas), encontravam-se neste período, em situação de considerável penúria e abandono. A despeito dos dispositivos legais em -vigor desde Pombal, contimuaram as velhas práticas coloniais dos descimentos e do engajamento forçado de índios em atividades produtivas. Não bastando esta prática indigenista repressiva e de extermínio, dos descimentos e da utilização do trabalho indígena, os grupos tribais de toda a região amazônica foram atingidos por uma série de epidemias, que associando a sensibilidade da população indígena para moléstias - infecto-contagiosas, às más condições de trabalho e de vida dessa população, registraram um número avultado de mortos (MOREIRA NETO, 1971, p. 1-7).

Com o extermínio dos grupos indígenas mais facilmente acessíveis, os poderes públicos, além de particulares, passam a se abastecer de trabalhadores indígenas das áreas ainda então mais densamente povoadas, como dos rios Madeira, Solimões e Negro. O recurso de aliciar coercitivamente 
Índios para o trabalho na região do rio Negro, por exemplo, deu origem a uma sucessão de revoltas indígenas, a partir de meados do século XVIII.

Unido aos Índios como força de trabalho, havia também um contingente expressivo de escravos negros, mulatos e mestiços de vários tipos, mas, principalmente, por uma grande população de "tapuios", índios destribalizados (MOREIRA NETO, 1971, p. 14). De qualquer forma, a questão social apresentava-se através da oposição entre os homens, por critérios de origem étnica e sócio-econômica.

As rebeliões e conflitos indígenas, aliados ao ambiente conflituoso de toda a região, geraram, no período, grandes rebeliões, dessas massas oprimidas das quais a mais significativa foi a Cabanagem.

" A Cabanagem foi o momento histórico da tentativa de emergência dessa massa de "tapuios" e outros mestiços, social e etnicamente degradados, e que procuravam escapar aos rudes moldes da sociedade colonial por uma rebelião armada que, a despeito de seus aspectos políticos mais aparentes e explícitos, tinham um conteúdo de mudança social extremamente revolucionário para as condições locais. (...)" " (MOREIRA NETO, 1971, p. 14).

Entre as tensões, ataques e a violenta repressão que o movimento desencadeou, o resultado histórico foi trágico. Os índios pagaram alto preço pelos processos de desorganização, dispersão ou transferência forçada de populações, mas principalmente, pela depopulação que, em muitos casos, dizimou quase integralmente os grupos indígenas da região. Mas isto 
não afetou somente aos índios, o custo da Cabanagem afetou também toda a região, provocando a desorganização de toda a vida econômica e social, a destruição ou o abandono das áreas de produção agrícola ou extrativa, o agravamento das condições de vida e de saúde da maioria da população, sendo que os surtos epidêmicos daí decorrentes aumentaram consideravelmente o alto custo em vidas humanas cobrado pela rebelião.

Em se tratanto especificamente dos índios, o movimento resultou na mais feroz repressão, que acabou por atingir todo e qualquer grupo tribal, pela mera suspeita de ter dado guarida, participado ou simpatizado com os cabanos: os Mura, do rio Madeira, calculados em 60 mil índios no início do século XVIII, praticamente foram eliminados; também foram furiosamente reprimidos os Munduruku e Mawé, do rio Tapajós, que tiveram suas aldeias invadidas e a população dispersa e transferida para trabalhos forçados.

Embora continuasse a exploração das "drogas do sertão", com os conseqtientes conflitos envolvendo índios, desde as primeiras décadas do século XIX, outro produto passa a se constituir no móvel da expansão econômica da amazônia: a borracha. Esta, como se viu, desenvolveu-se em dois ciclos sucessivos: o primeiro, foi desencadeado por uma verdadeira invasão da floresta por bandos de "caucheiros" que percorreram quase todo o vale amazônico em busca da castilloa elástica. Dada a forma de exploração do látex, abatendo-se as árvores, os "caucheiros" tinham de mover-se continuamente em busca de novos cauchais, cobrindo imensas distâncias. Assim, nenhuma tribo, em cujos territórios havia a castilloa elástica conseguiu fugir do centro desta frente (RIBEIRO, 1977, p. 23). A rápida ocupação de áreas até então virgens de conta- 
to ou escassamente penetradas, levou a uma redução drástica dos territórios tribais. Juntamente com este quadro gerador de conflitos com os índios, estavam os descimentos e o aliciamento de índios para o trabalho. A consequência não poderia ser outra:

"(...) Vários grupos indígenas das áreas onde se exerceu o esforço principal de expansão da frente extrativista, como o. Xingu, foram afetados seriamente, ocorrendo não raro a extinção completa dessas sociedades ou, nos casos mais benignos, uma drástica depopulação que invalidou os sistemas de produção e organização social indígena e forçou a sua dispersão. Tal foi - caso, entre outros, Tucunyapé, dos Juruna, dos Shipaya e dos Curuaya, do Xingu。( o.)" (MOREIRA NETO, 1971, p。87)。

A segunda fase foi marcada pelo momento em que começou a escassear a Castilloa, obrigando a frente de expansão a se dirigir às terras mais baixas do vale, em busca dos seringais - havea brasiliensis. Nessa produção, foram exploradas sucessivamente as zonas baixas do Amazonas, primeiro no Pará, depois o médio e alto curso, até o Solimões; finalmente, todos os rios tributários, desde a foz até as cabeceiras (RIBEIRO, 1977, p. 23-24)。

É importante a observação de que para a exploração extrativista, a terra não tinha em si mesma um valor, o mesmo em relação à floresta que a cobre. o que interessava realmente eram as espécies consideradas úteis. Por isso, não se cogitava ou disputava a posse legal das terras, mas o domínio e o controle das vias de acesso aos seringais. o domínio 
dos cursos d'água e dos meios de transporte era condição básica para o controle dos trabalhadores.

A produção se reclizava, como se viu, sob o sistema do "aviamento", marcando a clara dominância de um sistema mercantil, onde ao lado do patrão, outro elemento atuava para o funcionamento desta economia: o regatão. Este chegava até onde não ia o seringalista. É o traficante que conduz a mercadoria no barco em que vive, circulanco por todos os rios e igarapés, onde haja algum produto para trocar por aguardente, sal e uma infinidade de quinquilharias. Parte substancial de sua atividade consistia no desvio dos produtos dos seringais; mas sua empresa maior eram os índios, que coletavam as "drogas do sertão" e as trocavam por quase nada (RIBEIRO, 1977, p. 27).

Enquanto nas demais regiões do Brasil toda a problemática indigenista, principalmente na segunda metade do século XIX, estava ligada à questão da terra e dos aldeamentos, na Amazônia se manifestava de outra forma: pelos descimentos e engajamento forçado das populações indígenas como força de trabalho e pela exploração dos regatões, ambas as situações provocando conflitos com os índios.

Quanto ao primeiro aspecto, os descimentos e o engajamento forçado de populações indígenas como força de trabalho, sempre permeados por conflitos esporádicos com os indígenas, se dava especialmente nos setores ligados à exploração da borracha, de castanha, de extração de madeiras e óleos vegetais e no transporte fluvial.

Exemplo típico desta situação é dado pelo relatório de 1871 do presidente da Província do Amazonas, em que relata os motivos para ter adotado o expediente dos descimentos: 
"...no intuito de obter serventes para o serviço das obras públicas, concorrendo ao mesmo tempo para a civilização dos índios catequisados e nestes incutindo o quanto possível o amor ao trabalho, tenho conseguido, auxiliado pelo digno Diretor Geral dos Indios e por outros prestimosos cidadãos, conservar constantemente naquelas obras nesta capital, uma turma de índios que por enquanto pouco excede ao número de 40, composta de contingentes de diversas tribos e localidades da Província sendo êstes contingentes regularmente substituidos de dois em dois mêses, ..." (REIS, apud MOREIRA NETO, 1971, p。89).

No mesmo relatório, o presidente da Província diz do recurso de interessar e atrair com incentivos diversos, os chefes indígenas, do mesmo modo que estes "capitães" são u.tilizados como chefes de expedições punitivas contra grupos hostis e arredios:
"... últimamente, com um contin- gente de índios das margens do Rio Uaupés veio of erecer-se para o serviço o respectivo tuxáua a quem, para mais animá-lo, mandei empregar com maior jornal como feitor de índios em serviço nas referidas obras。" (Idem, p。89- -90)。

Quanto à exploração dos regatões, esta se verificava principalmente nas áreas em que os grupos indígenas escapavam ao controle direto dos seringueiros. Para exemplificar esta situaçãó, é interessante recorrer-se a um relatório de 1862, do presidente da Província do Pará, em que Araújo BRUS- 
QUE analisa a atividade espoliativa desenvolvida pelos regatões entre as populações indígenas, com dados demonstrativos da exploração destes comerciantes sobre os índios:

"(...) Dóceis ao contato de inteligência mais cultivada do que a sua, o índio em vossa Província acolhe benigno no seio de sua maloca aqueles que o procuram。Certos disso não faltam aventureiros, que transpondo enormes distâncias, penetram até - lugar de sua residência, e mediante o adiantamento de alguns objetos, que o índio reputa de súbito apreço, dentro em pouco ganha império sobre a tribo, a qual governa a seu bel prazer. ... E o pobre Índio the obedece cegamente! ... Para logo os destinar a colhida do óleo, da castanha, a extração de salsa, e de outros produtos naturais. $\mathrm{E}$ quando passados três ou quatro meses de árduo trabalho, regressa ao grêmio da aldeia, êle thes faz a conta de modo que o mísero índio the fica devendo ainda. Para que possais aquilatar o grau de usura e imoralidade dêste comércio execrando, eu vos darei a taxa do preço de algumas mercadorias vendidas ao pobre Índio no Alto Gurupi e no Capim ... No Gurupi um corte de calças de algodão ordinário, que custa nesta cidade mil réis, é dado ao índio em troca de um pote de óleo de copaíba... que vale por conseguinte nêste mercado $20 \$ 000$. Uma arma de fôgo ordinária no valor de 5000 réis é dada em trôco de três potes de óleo. Um barril de pólvora que custa 
$17 \$ 000$ réis é o equivalente de oito potes de óleo, que valem 160\$000。(..)" (BRUSQUE, apud MOREIRA NETO, 197I, p。49-50).

Do mesmo relatório consta um conflito ocorrido na aldeia Traquateua, dos índios Tembé, no Alto Purus, provocado pelo regatão Policarpo José Tavares.

Ao lado dessas ações, estreitamente ligadas ao tipo de exploração" econômica levada a cabo na região amazônica, destacaram-se outrạs, mais ligadas à administração desenvolvida pelo Estado, como as colônias militares, os aldeamentos e os projetos de colonização.

A instituição de colônias militares, que havia caracterizado a administração de D. João VI, foi especialmente importante no vale do rio Araguaia. A instituição de colônias representava um instrumento de dominação coercitiva, sempre pronto a ser acionado contra os índios, seja para garantir a ocupação de seus territórios ccmo para reprimir qualquer resistência à vontade dos Diretores, Missionários ou proprietários de terras. Os grupos indígenas, hostis ou pacíficos, sofreram todos os sérios processos de degradação e de desorganização de suas comunidades pela intervenção de praças e ou degradados。 Os conflitos que surgiram atingiram a todas as colônias militares.

Sobre os projetos de colonização, é interessante se verificar a estreita relação entre estes e os sinais de decadência econômica em comparação com outras regiões. Mais que isto, a necessidade de projetos de colonização, notadamente dos projetados para utilizar da força de trabalho indígena, passa a ser uma imposição da estrutura econômica nacional, uma vez que as economias periféricas à expansão cafeeira viam-se 
afetadas pela evasão da mão-de-obra escrava. Unida a isto, estava a admissão da impossibilidade de atrair para estas regiões o interesse de colonos europeus, determinando um programa de colonização fundado basicamente na possibilidade de utilização do braço indígena.

Entre outras regiões, destacam-se as tentativas de expansão econômica, através deste tipo de projeto de colonização, realizadas no Maranhão. Segue abaixo um trecho do relatório do presidente desta Província, Magalhães TAQUES, de 1857, em que destaca a utilização dos ínđios Guajajara nos projetos de colonização:

"(...) Os Índios Guajajara do têrmo da Barra do Corda merecem particular atenção; constituem as 13 famílias ou malócas, estabelecidas em distâncias de 5 a 6 léguas da vila com 2.600 indivíduos, por estimativa. Esses índios são amigos da paz e do trabalho, dóceis, hospitaleiros e as mulheres quase que só a sua. ... Entretanto o govêrno providencia, como o exige a manutenção da ordem pública, procurando aproveitar os braços selvagens. Firme no propósito de não consentir que os índios sejam maltratados, enganados e trucidados por expedições dirigiđas à vinganças contra esta geração desherdada, penșo que por êstes meios se poderá conseguir muito mais em benefício de sua civilização do que por nenhum outro dos que atualmente podem ser empregados, e que as despezas que se fizerem com 0 fornecimento de instrumento, utensílio e presentes, que ins- 
pirem ao selvagem não só a afeição para conôsco, mas também o gôsto e as necessidades de vida mais culta... Com elas popuar-se-ão despezas muito mais acrescidas e necessárias para repelir as hordas bárbaras... A ordem pública tem pois, muito a ganhar neste sistema, que importa uma verdadeira economia." ( TAQUES, apud MOREIRA NETO, 1971, p. 109-110).

Para completar o quadro sobre o indigenismo no vale amazônico, vale dizer que a legislação indigenista básica do Império não foi eficaz para bloquear a continuidade da ação repressiva e expedições punitivas contra grupos indígenas. Na região amazônica, essas continuaram no transcorrer de todo o período。

Em relatório do Presidente da Província do Amazonàs, de 1853, há referência ao uso da "força armada" contra indios:

"(...) Ao contráxio dos incidendentes ou ataques dirigidos contra os índios, as ações hostis dêstes são prontamente enfrentadas com fôrça armada. Imediatamente após o ataque à aldeia de Santa Cruz, foram enviadas tropas do Forte de São Gabriez em perseguição aos Carapaná, que já se haviam, entretanto, retirado e não foram encontrados。 Em junho do mesmo ano, o curso principal do Madeira e seu afluente, - Aripuanã, são palco de correrias de índios Mura e Arara, que a tacam ocupações isoladas de nacionais ou grupos móveis de coletores do produtos florestais. Esses novos surtos de hostilida- 
de indígenas são controlados segundo uma técnica tradicional, usada com êxito desde os primeiros anos do ceríodo colonial; contra os índios hostis do Madeira são enviadas expedições punitivas, integradas por índios Mura e Mrundurucu aldeados, havendo uma fôrça volante dos primeiros atacando os Arara, com a morte de alguns dêstes, ficando os-outros prisioneiros." (MOREIRA NETO, 1971, p。72).

Outra forma característica desta ação repressiva contra índios, encontra-se nos episódios ocorridos durante a construção da Estrada de Ferro Madeira-Mamoré。 Os Índios que habitavam a região cortada por esta estrada de ferro, privados de qualquer atitude protecionista por parte dos órgãos oficiais, foram submetidos a uma ação permanente e indiscriminada de expedições punitivas, "pagas e dirigidas pelas companhias construtoras e por proprietários de terras", com a anuência e participação do poder repressivo do Estado (MOREIRA NETO, 1971, p. 88 e s.)。

Diante do avanço desta "civilização", representada pelos extratores de produtos vegetais, poucas eram as possibilidades históricas de sobrevivência das comunidades indígenas, salvas por circunstâncias fortuítas:

"Assim, o colapso da economia extrativa foi a salvação das populações indígenas remanescentes da amazônia. Uma década mais de atividades, ao rítmo em que se efetuavam, certamente, teria levado quase todas as tribos do vale ao extermínio。 (...)" (RIBEIRO, 1977, p。29)。 
A população indígena do nordeste, no início do século XIX, não passava de meros resíduos do que haviam sido. Essa situação era uma decorrência da forma como havia sido realizada a ocupação econômica no transcorrer do período colonial e da política de extermínio adotada contra os grupos tribais。

Inicialmente, a avalanche atingiu grande parte dos grupos Tupi que habitavam a costa, como os Caeté, que foram exterminados pelas "guerras justas" ordenadas contra eles ainda na segunda metade do século XVI。Os sobreviventes foram escravizados ou emigraram em direção ao interior do país. Outros grupos Tupi, como os Potiguara da Paraíba e Pernambuco, também sofreram processo semelhante, acabando como força de trabalho escravo nos engenhos de açúcar da região. Ainda sobre a Paraíba, não convém que se esqueça que a conquista desta re-. gião, em fins do século XVI, deu-se à custa de prolongadas guerras contra as tribos litorâneas que a habitavam.

Ao lado desses grupos Tupi, existia grande número de grupos tribais, linguística e culturalmente diversos, que habitavam o interior de todo o Nordeste até o Maranhão, como os Kiriri, Pancarau, Fulniô e Tarairyow. Estas tribos do interior, primeiro foram alcançadas pela penetração pastoril, mas foi com a invasão holandesa e com a expulsão destes, que os portugueses desenvolveram uma violenta campanha contra a população indígena nordestina, que se prolongou até o início do século XVIII. Após a reconquista portuguesa, as expedições punitivas percorreram os sertões, levando a guerra a todos os redutos indígenas ou de escravos africanos foragidos - os "quilombos" - que pudessem ser localizados。

Esse período foi denominado de "Guerra dos Pár- 
baros" e se prolongou até a segunda metade do século XVII, atingindo o interior de Alagoas, Pernambuco, Paraíba, Rio Grande do Norte, Ceará e Piaú, exterminando os maiores grupos tribais da região. Dessas guerras, participaram como uma "contribuição" para a expansão pastoril, vários bandeirantes paulistas, especializados na caça ao índio (MOREIRA NETO, I971, p. 282-283)。

Já no século XVIII, esta população indígena foi reduzida a uma ínfima. fração do número que alcançava na época da "Guerra dos Bárbaros". Ainda assim, no transcorrer de todo - século, continuaram os índios a serem submetidos aos costumeiros processos de expropriação de suas terras, de exploração do trabalho e de epidemias.

t por tudo isto que se disse que a população indígena nordestina no início do século XIX não passava de resíduo do que havia sido. A situação é tão grave que em algumas Províncias dessa região nem sequer há menção da existência de índios no transcorrer do século XIX, como o Piaú́ e Rio Grande do Norte; na Paraíba, as informações são de pouca significância (Idem, p. 287).

No transcorrer do período em questão, a mesma prática indigenista continuou a ser exercida, sendo caracterizada psila continuidade das ações de extermínio e, principalmente, pelo contínuo processo de expropriação das terras indígenas. Processos esses ocorridos num ambiente de rebeliões populares das quais participavam os indígenas, e que marcaram a história das relações entre índios e brancos em toda a primeira metade do sécuIo XIX; ou de conflitos entre índios e os agentes da ocupação econômica, em praticamente todas às regiões em que sobreviviam remanescentes aborígenes. 
Ñָo é difícil de se entender as condições geradoras da problemática indízena nordestina, toda ela centrada na questão da apropriação da terra, se se levar em conta que a exploração econômica no nordeste deu-se no período colonial furdada na agricultura e pecuária, atividades em que a posse legal da terra é fator fundamental.

Com as transformações econômicas verificadas no decorrer do século XIX, a economia nordestina foi uma das que mais sofreu com a herança deixada pelo período colonial. Por um lado, pelo fato das relações de produção aí implantadas serem escravistas e, à medida que começou a aumentar a contradição representada pela escravidão africana, toda a estrutura produtiva nordestina passou a sofrer as consequências dessa situação. Por outro lado, dado o próprio caráter da economia colonial, a economia nordestina foi montada com o objetivo básico de produzir uns poucos produtos, com mercado na Europa, que entravam no circuito mercantil sob as condições do pacto comercial; mas à medida que o capitàlismo se transformava, exigindo a produção em massa de matérias-primas ou de alimentos, bem como transformava as condições sobre as quais se dava a apropriação do trabalho excedente, a já decadente economia nordestina passa a ser anacrônica, entrando em contínuo processo de estagnação.

Passado o período colonial, mas permanecendo ainda o escravismo, uma terceira contingência aprofundou ainda mais a precária situação nordestina: agrava-se o problema da constante queda dos preços dos produtos básicos aí produzidos: o açúcar e o algodão.

Ainda que o problema dos preços tenha se mantido ao longo de toda a economia mercantil-escravista nacional, ve- 
rifica-se uma Ienta recuperação da produção e dos volumes exportados. O açucar passa, de uma média anual de $30 \mathrm{mil}$ toneladas no século XVIII, para uma média anual superior a $100 \mathrm{mil}$ toneladas no transcorrer do século XIX (CANO, 1981, p.993)。o algodão sofreu processo semelhante, sendo que no transcorrer do século XIX acaba se constituindo na principal atividade do complexo econômico nordestino, com um crescimento lento, mas persistente, passando de $110 \mathrm{mil}$ para $190 \mathrm{mil}$ tóneladas entre a primeira década do século XIX e a primeira década do século XX (Idem, p. 93).

Considerando-se que as técnicas produtivas no nordeste conservaram-se mais ou menos estáveis no decorrer do período, pode-se concluir que o aumento da produção do açucar e do algodão deram-se basicamente através da ampliação das áreas de plantio.

É, pois, neste quadro de ampliação da área de produção que se pode entender porque toda a problenática indígena do Nordeste estava diretamente relacionada com a questão da terra e não com a utilização da força de trabalho. Sobre a questão da força de trabalho, não convém esquecer que FURTADo (1982, p. 145-149) verifica que a população nordestina aumentou a uma taxa de 1,2 \% ao ano, muito superior ao da renda gerada pelo setor exportador, tendo-se ainda que levar em consideração que o crescimento populacional era tal que possibilitava os fluxos migratórios do nordeste em direção à região amazônica, à região cafeeira e ao centro-oeste.

o Índio, assim, era considerado um impecilho que bloqueava a "ocupação econômica" de terras necessárias ao desenvolvimento da região。 o resultado, na prática, foi ou do extermínio físico do índio para que se "desinfetassem" 
as terras necessárias; ou, de expropriação das terras indígenas, graças à adoção de técnicas sobejamente conhecidas desde - período colonial. Evidentemente, a manifestação prática decorrente dessas situações foram diferenciadas até a metade do século XIX e no decorrer da segunda metade deste século, quando a expropriação foi possibilitada pelo uso dos diplomas legais de então: a Lei 601, de 1850; a decisão do Ministério do Império de 1850 e o Decreto no 1318 。

Primeiramente, é preciso que se leve em conta que as Províncias do nordeste brasileiro, do mesmo modo que as da região amazônica, sofreram durante toda a primeira metade do século XIX, sucessivos conflitos e revoltas populares. Antes da independência, todo o nordeste foi envolvido na revolução de 1818; após esta, foram vários os motins e revoluções, como: a Confederação do Equador; a Balaiada, que se estendeu do Maranhão ao Ceará; a revolta de Pinto Madeira, no Ceará; a Cabanada ou Guerra das Panelas, em Pernambuco e Alagoas, e outros movimentos que conturbaram toda a região.

O motivo para a ocorrência desses movimentos situa-se na própria estrutura econômica e social, que consagrava - princípio da grande propriedade agrícola, dos direitos muito amplos da aristocracia agrária sobre as massas populares, desprovidas de todos os direitos e de todas as oportunidades. Os indígenas se inseriam nesses movimentos:

"(...) Os remanescentes indígenas das áreas convrisionadas participaram, em muitos dos conflitos e lutas que se seguiram, às vêzes recrutados mais ou menos coercitivamente pelas fôrças governamentais, mas, outras, integrando-se ao movimento rebelde 
através de um processo de adesão até certo ponto consciente." (MOREIRA NETO, I971, p. 288)。

TaI como aconteceu na Amazônia com a Cabanageri, o mesmo se passou com os índios do nordeste durante e depois dos movimentos sociais: intensa dizimação de grupos indígenas que participaram, apoiaram ou simpatizaram com os movimentos.

Além da repressão armada, os índios do nordeste foram afetados por medidas de alcance mais duradouros:

"(...) Considerados rebeldes, viram-se imediatamente privados da posse de suas terras, legalizando-se a usurpação como medida imposta pelos interêsses da segurança nacional。 E a prática tradicional da ampliação das largas propriedades rurais do interior às expensas das áreas ainda ocupadas por grupos indígenas, será agcra justificada não só como medida que atenda aos interêsses do desenvolvimento econômico do país, mas, também, como ação nacional, ameaçada esta pelo que Varnhagen e outros ideólogos oficiais do regime definiram como uma "rebelião armada dentro do Império"." (MOFREIRA NETO, 1971, p. 290).

Com essas ações, a população indígena da região nordestina sofreu a mais drástica redução populacional. Nem por isso, os remanescentes indígenas foram deixados em paz, pois, tem início o processo de extinção dos aldeamentos, sob o argumento de que a população indígena já estava "plenamente integrada" na sociedade regional, impondo-se a transferência destas terras para particulares.

Entre os casos ocorridos merecem destaque, a tí- 
tủo de ilustração, as expropriações ocorridas em Pernambuco e em Alagoas.

Em Pernambuco têm-se notícias de expropriação em 1868, 1875 e em 1877. Em 1868, há referência da existência dos seguintes aldeamentos: de Brejo dos Padres, de Urubá, de Santa Maria da Boa Vista, da Ascenção, de Barreiros e o de Panema. Assinala-se a extinção dos aldeamentos de Baixa Verde, Desde 1848, e o da Escada, extinto em 1867.

Em 1875, prosseguiam os esforços para a extinção dos aldeamentos indígenas da Província de Pernambuco. No relatório do presidente da Província, com data desse ano, além de se referir aos aldeamentos existentes e aos extintos, há uma pasæagem interessante revelando a contimidade dos conflitos de terras, nos aldeamentos ainda existentes:

"Segundo o último relatório do engenheiro encarregado da medição das terras públicas desta Província, está começada a medição e demarcação dos cinco aldeamentos de São Miguel de Barreiros, e terminadas estas, proceder-se-á do mesmo modo com o do Riacho do Mato, igualmente extinto.Acham-se ocupando lotes de teria, que thes foram demarcados, no extinto aldeamento de São Miguel de Barreiros, 36 famílias de índios ... Existem ainda cinco aldeamentos, os de Cimbres, Panema, Brejo dos Padres, Assunção e Santa Maria. Acham-se extintos os de Baixa Verde, Escada, São Miguel de Barreiros e Riacho do Mato.o referido engenheiro é de opinião que há conveniência na completa extinção de tais aldeamentos, 
que, além de haverem já perdido sua razão de ser, pela maneira porque estão seus habitantes confundidos com a população, e assim esquecidos seus usos primitivos, continuam a ser o motivo de constantes lutas entre os indios e seus confluentes, os quais terminam sempre com perdas de terras para aquêles que dêste ou daquêle modo são espoliados pelos especuladores que os perseguem。( ...)" (IUCENA, apud MOREIRA NETO, 1971, p. 308-309 - o grifo é nosso)。

É simplesmente impressionante a rapidez com que se realizava o processo de espoliação das terras indígenas em Pernambuco, a ponto de dois anos após, 1877, registrar-se. a existência de somente dois aldeamentos ainda não extintos, mas igualmente reivindicada a expropriação das terras:

$"(\ldots)$ Existem ainda dois aldeamentos, o de Cimbres e Assunção, cuja existência não tem mais razão de ser ... A conservação dês tes aldeamentos somente serve para depôr contra os nossos costumes públicos e para a satisfação dos cálcuzos eleitorais daqueles que desejam e procuram ser Diretores dos fndios. (...)" ( LUNA FREIRE, apUd MOREIRA NETO, 1971, p. 310).

Em Alagoas, o mesmo processo de extinção de aldeamentos era executado pelo governo provincial. Na medida em que os índios resistiam ao processo de expropriação que sofriam, ordenavam-se providências policiais para controlá-los. Em relatório do presidente da Província de Alagoas, Dr. Iuiz Rômulo Perez de Moreno, de março de 1873, informa que foi au- 
torizado pelo Ministério da Agricultura a extinguir as aldeias de índios ali existentes, sendo que já havia baixado ordens nesse sentido. A seguir, informa a reação dos índios e as providências que tomou:

"... os intitulados. Indios, po-
rém, continuam a disputar a pos-
se dêsses terrenos procurando ex
tendê-la a outros limítrofes. Em
consequência dêste fato deu-se
o.o um conflito entre alguns dê-
les e os legítimos possuidores
do terreno, resultando a morte
de um o ferimento de três da-
queles indivíduos. A vista de
tão desagradável ocorencia,
criei... um Distrito Polinial no
lugar denominado Nerim.oo"(MORE-
No, apud MOREIRA NETO, I97I, D.
327).

Diversa situação era a enfrentada pelos indios no extremo-sul do país, que foram afetados a partir de 1824 por outra frente colonizadora representada pelos imigrantes europeus. Convém recuarmos até o período colonial para melhor entendimento da questão.

No século XVI, a região era habitada por vários grupos tribais: os Tupi, que ocupavam a faixa litorânea; os Jẽ ocupando o planalto, e incluindo três importantes grupos: Ianá, Maromimi e Puri; e os Guarani, ocupando algumas faixas litorâneas e no extremo oeste (MONTEIRO, 1984, p。22).

Os Tupi desde o início da colonização foram utilizados: inicialmente de forma amistosa, depois como força de trabalho escrava. o crescimento da empresa agrícola no litoral brasileiro impulsionou as expedições dos mamelucos paulistas a, praticamente, todas as regiões brasileiras em busca de índios para o comércio escravista.Estas "bandeiras" percorreram 
durante a primeira metade do século XVII os principais centros populacionais indígenas do sul do país - principalmente as "reduções jesuíticas" - de onde trouxeram milhares de indígenas das tribos Guarani e Carijó, além de terem provocado o extermínio de grande parcela de índios desses grupos tribais.

Desta forma, durante os três primeiros séculos de colonização, os principais contingentes populacionais expressivos de vários dos principais grupos tribais já haviam sido atingidos restando, dos mesmos, remanescentes que viviam embrenhados no sertão desde a expulsão dos jesuítas - em 1759 - e consequente destruição do sistema de reduções.

Porém, o trecho da mata atlântica e de araucária, no interior de São Paulo, Paraná e Santa Catarina, ainda permanecia intocado até o início do século XIX, sendo habitat dos Guaianá, de língua Kaingang, cuja sobrevivência deveu-se a serem tidos como rudes e indomáveis, não interessando aos bandeirantes como mão-de-obra escrava (RIBEIRO, 1983, p. 75).

A partir da segunda década do século XIX - 1824 (AZEVEDO, 1961, p. 74-75), essas áreas cobertas ainda pela mata atlântica, começaram a ser ocupadas por imigrantes alemãese, a partir de meados do século, também por italianos e eslavos. Esses imigrantes europeus, trazidos ao Brasil por ini ciativa governamental ou particular, fundaram uma orğanização econômica e social bem distinta do resto do país: grande parcelamerto da propriedade fundiária, ausência de latifúndio; em vez das grandes lavouras do tipo exportação, pequenas culturas e outras atividades de caráter local e destinadas ao abastecimento interno (PRADO JR, 1982, p.204).Essa ocupação econômica, mesmo com o apoio das companhias de colonização e do governo, não apresentava aquele caráter de deslocamento de mas- 
sas humanas; o colono europeu, depois de conduzido a seu lote, permanecia isolado em sua porção de terra, juntamente com sua família (RIBEIRO, 1977., p。107).

Foi nessas regiões que ocorreu um dos principais problemas de relação entre índios e colonos europeus do extremo-sul: com os Botocudos ou Coroados de Santa Catarina, conhecidos etnologicamente por Xokleng ou Aweikoma。

Os Xokleng (como iremos aqui denominá-los) viviam nas matas ricas em pinheiros, desdes as proximidades da costa até o centro de Santa Catarina, ao longo de todo o vale do rio Itajaí e seus formadores. Alguns bandos estendiam o território tribal ao Norte, até o Paraná, e ao sul até a região dos campos ocupada por criadores de gado. Foi nessa região que alojaram os colonos europeus com suas famílias (SCHADEN, 1977, p. 84).

Camponeses europeus, habituados exclusivamente com o trabalho agrícola, submetidos a condições bastante duras de colonização, viram-se a braços com o terror ao índio armado de flechás e lanças e que vigiava todos os seus movimentos. Não bastasse a situação em si mesma, esses colonos europeus vinham armados dos sérios preconceitos trazidos da Europa, em relação ao índio, vendo nele o inimigo implacável, pronto a roubar e a matar, tornando qualquer empreendimento impossível (RIBEIRO, 1983, p。76). Outra não poderia ser a consequência:

"Após os conflitos que se seguiam a cada penetração, o pânico se apossava dos colonos; e grupos deles abandonavam a terra dirigindo-se a são Paulo onde poderiam trabalhar em segurança, embora como assalariados, ou regressavam à Europa. Muito cedo o 
Governo se viu compelido a tomar providências para estancar o êxodo dos colonos. A primeira delas, foi destacar uma guarnição militar para expulsar os índios. A esta se seguiram outras medidas, através de todo o século passado, sem que se conseguisse pôr fim aos conflitos。 Além das guarnições, foram tentadas também, sem sucesso, as turmas de sertanejos armados para dar cabo dos índios, por conta do Governo provincial, do município de Blumenau e das companhias de colonização.

$(\ldots) "$ (RIBEIRO, 1977, p. 108).

Assim, foi armando os próprios colonos e enchendo as matas de matadores profissionais de índios - os "bugreiros" - que a colonização do vale do Itajaí prosseguiu. E na medida em que prosseguia, estreitava cada vez mais o círculo sobre os índios, amiudando-se os conflitos. Nessas situações, era difícil convencer os colonos apavorados de que não podiam matar índios, que, por vezes, também os matavam, pois assim agindo só contribuíam para aumeritar o conflito (SCHADEN, I977, p. 85).

"No meio desse cerco feroz, o Índio era compelido a um comportamento de fera. Esgueirava- se pela mata, procurando confundir-se com ela para não ser percebido ... Para as cerimônias em que vários bandos deviam reunir-se, cercavam-se de todas as precauções, cavava profundas trincheiras e minava as imediações com fojos-buracos disfarçados com uma fina camada de gravetos e folhas que escondiam lanças e estrepes

." (RIBEIRO, 
Os conflitos continuavam e à menor confirmação de perambulação de índios, logo chamavam um bugreiro espe cializado para o ataque planejado contra os índios, considerados como "foras da Zei", ficando os assassinatos não somerte impunes, mas estimulados como obra meritória.

Em certo sentido, isso correspondia adequadamente à política indigenista levada a cabo pelo Império. Viu-se anteriormente como em.muitas outras situações a orientação geral dos "negócios indígenas" era de tolerância para com as expedições armadas contra índios, o mesmo se verificando em relação às empresas particulares contra as populações indígenas. Não basta dizer que as ações repressivas eram "toleradas"; na verdade, eram autorizadas ou mesmo incentivadas diretamente por subsídios dos órgãos encarregados da política indigenista.

Essa situação é claramente evidente em relação aos Índios Xokleng, pois em 1883, o Ministro da Agricultura, Affonso Augusto Moreira Pena (mais tarde presidente da Reoública), pôs à disposição da Província de Santa Catarina uma verba especial de $500 \$ 000$ réis destinada à "repressão aos selvagens", devendo ser usada para "reunir gente suficiente para garantir a população de novos assaltos dos selvagens (MOREIRA NETO, 1971, p. 156).

Com isso,a política de extermínio continuava com tal crueldade que a justificativa "civilizatória" ficava claramente exposta. A ação dos "bugreiros" e principalmente a forma como realizavam o extermínio dos índios foi assim descrita por Eduardo de Lima e Silva HOFRHEN:

"Infinitas precauções tomam, 
pois é preciso surpreender os índios nos seus ranchos quando entregues ao sono. Não levam cães. Segrem a picada dos índios, descobrem os ranchos e, sem conversarem, sem fumarem, aguardam a hora proprícia。色 quando o dia está para nascer que dão o assalto. 0 primeiro cuidado é cortar as cordas dos arcos. Depois praticam o morticínio. Compreende-se que os índios, acordados a tiros e a facão, nem procuram defender-se e toda heroicidade dos assaltantes consiste em cortar carne inerme de homens...

Depois das batidas dividem-se os despojos que são vendidos a quem mais der, entre eles os troféus de combate e as crianças apresadas. (...)" (Apud RIBEIRO, 1971, p. 109-110)。

Essa situação envolveu os Xokleng com imigrantes europeus e continuou, no transcorrer de todo o século XIZ, só terminando com a pacificação do grupo em 1914 .

Embora não se tenham dados ou referências sobre as demais regiões do extremo-sul do país, o confronto entre esses índios e a colonização sulina foi significativo, dada as proporções que atingiram e a grande extenção territorial que compreendia, sendo possível aplicá-las às demais situações similares.

A região leste, em sua parte central, ao longo dos rios Pardo, Jequitinhonha, Mucuri, São Mateus e Doce, não constituía em si mesma uma unidade econômica autônoma, porém 
resultou numa política indigenista mais ou menos comum.

Essa vasta região, compreendida pelo sul e sudeste da Bahia, nordeste, leste e sudeste de Minas e pelo Espírito santo, ainda possuía no final do século XVIII e início do século XIX amplas porções da floresta atlântica ainda indevassadas. Ao longo dos rios que cobrem essa vasta região, viviam vários grupos tribais conhecidos como Aimorés, Botocudos, por vários dos grupos tribais usarem botoques, ou Coroados, pelo corte do cabelo formar uma espécie de coroa.

"(...) Por toda a periferia ela foi sendo invadida, a princípio por simples famílias de sertanejos deslocados, que procuravam terras sem dono para instalar-se; depois, por sucessivas ondas de invasores que avançavam organizados, dispondo de grandes capitais, de amparo oficial e até de tropas privadas para garantir suas conquistas。" (RIBEIRO, 1977, p。93)。

Um após outro, os grupos indígenas foram sendo atingidos e à medida em que se opunham à invasão de seus territórios, eram eliminados em chacinas bárbaras, posto que ao invasor não interessava poupar vidas para utilizá-las no trabalho escravo, mas desocupar a terra para poder utilizá-la na agricultura。

A penetração se deu a partir de três polos: pelas frentes de expansão que antecederam ao avanço do café, baseada na produção do algodão, do fumo e mesmo pelas plantações pioneiras de café, atingindo a região compreendida entre os rios Doce e Paraíba; a segunda frente situava-se entre os rios Pardo e Doce, consequência da expansão agrícola promovida após 
a decadência da mineração nas Minas Gerais; a última frente localizava-se entre os rios das Contas e o Pardo, em território baiano, representada pela expansão da produção cacaueira.

o martírio indígena teve início pela penetração agrícola, via região compreendida entre os rios Doce e Paraíba, empreendida por agricultores interessados na terra para a produção de algodão, do fumo e para as plantações pioneiras do café。

Essa região era ocupada pelos Puri-Coroado e Botocudo, que foram alvos de "Guerras Justas" e escravização no começo do século XIX, e a faixa de matas que ocuparam, destinadas, inicialmente, a colonos que ocupavam vastas regiões, indo atingir até os vales dos rios Jequitinhonha, Mucuri e são Mateus. Até meados do século XIX, os grupos tribais já haviam sido subjugados e os remanescentes recolhidos em aldeamentos sob a direção de missionários.

A outra frente de penetração situava-se entre os rios Pardo e Doce, região habitada pelos Botocudo. Inicialmente, os índios foram acossados, desde final do século XVIII até - XIX, com as fortificações erguidas ao longo do rio Doce para garantir a navegação contra o assédio de tribos hostis. No começo do século XIX, ao intensificar-se a penetração da frente agrícola, esses índios foram alvos de ataques que partiam concomitantemente de Minas Gerais e do Espírito Santo. Logo foram decretadas contra eles as Carta Régias em que o governo autorizava a "guerra ofensiva", assegurando o direito de tomá-los por escravos.

Numa situação intermediária entre a expansão econômica, provocada pela decadência da mineração e de ponta de lança da ocupação cafeeira, ambas responsáveis pela forma- 
ção de diversos núcleos de subsistência, tem-se uma frente de o cupação que oriunda de Minas Gerais, foi se fixar nos sertões despovoados do oeste de São Paulo. Esta frente subdividiu-se por duas reziões no interior do Estado: uma ao norte do rio Tietê, próximo aos rios Pardo, Turvo, Preto e São José dos Dourados; a outra, entre os rios Paranapanema e do Peixe.

"A penetração dos migrantes caracterizou-se pela ocupação e posse da terra, viabilizadas por meio de uma produção econômica voltada fundamentalmente para a subsistência e para a troca de produtos excedentes no mercado. (...) Estes grupos desenvolviam uma agricultura baseada- principalmente no cultivo do milho e na utilização de técnicas agrícolas rudimentares. Com a comercialização dos produtos agrícolas e a venda de animais, procuravam garantir o conjunto de ítens necessários à sua sobrevivência ." (BORELII, 1984, p. 47).

Essas regiões compreendiam o território de perambulação dos índios Kaingang, que tinham como território tribal básico a área localizada entre os rios Aguapeí e Peixe. Mesmo assim, a proximidade indígena originou contatos com as frentes de colonização.

De modo geral, entre 1842 a 1886, os Kaingang conviveram pacificamente com as famílias estabelecidas próximo ao salto de Avanhandava. Porém, a partir de 1886, passa a haver conflitos, conforme a descrição de F.R. BARROS:

"(..) E prosperavam os retireiros sem largamente derribarem a mata. Viviam aparentemente felizes os caingangues sem serem mo- 
Iestados. Assim foi até que uns benditos Pintos Caldeira feriram e mataram alguns índios quando estes roubavam milho de roça, atividade que não constituía nada de novo e nem revoltante aoミ outros moradores mais inteligentes e mais humanos. De tal feito em diante os caingangues tornaram-se hostis e ameaçaram a segurança dos povoadores. Não tardou um desfecho tremendo. Perto de oitocentos índios habitavam a região. No ano de 1886, num dia de mutirão realizado pelos mesmos Pintos Caldeira para derribada de matas, mais de duzentos índios surgiram no eito, à hora do aImoço, e, em meio a uma gritaria infernal massacraram a maioria dos trabaIhadores." (BARROS, apud BOREIII, 1984, ‥ 62-63).

Isto evidencia que apesar dos Kaingang possuírem um território mais ou menos definido, entre os rios Feio/Aguapeí e do Peixe, circulavam por uma região mito mais ampla, provocando conflitos com essa frente de expansiäo. Desde o início da ocupação surgiram as primeiras propostas de núcleos missionários. Mas as tentativas de catequização foram em geraI infrutíferas, não apresentando concretamente resultados satisfatórios.

Após o conflito de 1886, os moradores restantes abandonaram a região, que voltou a ser ocupada somente em 1904, quando ainda os conflitos persistiram.

Entre os rios das Contas e o Pardo era aberta uma nova fronteira, representada pelos plantadores de cacau. Esta área era habitade por dois grupos tribais: os Kamaxãn e 
os Pataxó. Estes viram as terras que lhes haviam sido reservadas serem rapidamente esbulhadas e, contre si, lançado violento extermínio, quer usando de jagunços emoreitados pelos grandes fazendeiros de cacau para o extermínio dos índios, quer pelo envenenamento das ağuadas e a contaminação proposital por bexiga (RIBEIRO, 1983, p. 75).

"Um século de perseguições levara os remanescentes dos $\mathrm{Pa}$ taxó e Kamakãn a uma simplificação radical de seu equipamento e a uma capacidade extraordinária de se dissimularem na mata, esgueirando-se de uma região para outra, sem serem jamais notados. (...)

Mas os chacinadores acabaram encontrando armas eficazes contra esses inimigos invisiveis, recorrendo a velhas técnicas coloniais, como o envenenamento das aguadas, o abandono de roupas e utensílios valiosos onde pudessem ser tomados pelos índios e, sobretudo, minando os arredores das casas e plantações com armadilhas montadas com armas de fogo." (RIBEIRO, 1977, p. 99-100).

Vista sob contexto mais amplo, a política e a prática indigenista que afetaram os grupos tribais localizados na região Ieste aqui compreendida, sofreram profundamente os reflexos do indigenismo pós-pombalino até a independência, com seu cunho progressivamerte anti-indigenista, através do qual se restabeleceram as permissões formais e os incentivos para a escravização do índio e a organização de forte repressão contra os mesmos. A intenção desta política era clara: permitir e possibiltar as condições para o alargamento da colonização das 
áreas por estes ocupadas. Assim, os aldeamentos existentes são condenados ao desaparecimento pela expropriação de suas terras e pela utilização dc índio como força de trabalho cativa.

As primeiras providências legais foram de restabelecimento da política de extermínio: a Carta Régia de 13 de maio de 1808, ordenando o extermínio contra os Botocudos de Minas Gerais, ratificade pela Carta Régia de lo de abril de 1809, e a Carta Régia de 05 de novembro de 1808 ordenando a "guerra ofensiva" ccntra os Kaingang de São Paulo. Fim todos esses documentos legais davo-se o mesmo destino aos remanescentes: o trabalho cativo, por 15 anos ou pelo tempo que durar sua "ferocidade".

A justificativa ideológica dessa mortandade foi a mesma que acompanhou a colonização européia desde seu início: o índio é o bárbaro, o feroz, o antropófago, o inferior...

o objetivo de tcda essa política era claro e manifesto: as áreas ocupadas pelos índios deveriam ser destinadas a colonos que as destinariam ao cultivo economicamente rentável. Este objetivo é tão claro que, um ano após a decretação da guerra contra os Botocudo de Minas Gerais, foi expedida nova Carta Régia, de 13 de julho de 1809, em que é ordenada explicitamente que "as áreas antigamerte ocupadas pelos Botocudo se fossem logo distribuindo cesmarias aos novos colonos que entrassem na tentativa de as povoar, e cultivar..."

Na medida em que se consideravam os índios como iguais, quanto a sua barbárie, rudeza e como empecilho ao desenvolvimento, não é difícil de se pressupor que a declaração de guerra, contra um determinado grupo tribal, acabava afetando todos os grupos tribais indistintamerte. Assim, a política 
indigenista adotade em relação aos grupos tribais de Minas e São Paulo acabou, na verdade, exterminando praticamente todos os grupos indígenas na área de desenvolvimento agrícola do século XIX. Aos remanescentes, restara a possiobilidade de penetrarem continuamente pelo sertão, medida que a curto prazo os afetaria, já que no final do século XIX e primeiras décad引s do século $\mathbb{X X}$, praticamente toda esta região foi ocupada pelo avanço econômico cafeeiro.

Quando da expansão inicial do café ao longo das encostas do Rio de Janeiro, e depois pelo vale do Paraíba, os índios já não constituíam empecilho, haviam sido exterminados quando do avanço da frente de subsistência。o café só encontraria o "empecilho indígena" numa etapa em que já estava plenameirte consolidada sua estrutra produtiva.

A economia cafeeira constituiu-se e consolidou-se no transcorrer da primeira etapa do século XIX. o ponto de partida da expansão cafeeira foi a vizinhança da cidade do Rio de Janeiro, seguindo para o sul acompanhando o litoral; na província de São Paulo o café era plantado em Ubatuba, Caraguatatuba e São Sebastião.

A implantação da economia cafeeira nessas regiões não enfrentou empecilho qualquer com relação aos índios, posto que estes haviam deixado de se constituirem "entrave para o desenvolvimento" desde as campanhas de extermínio promovidas durante o século XVI, notadamente no transcorrer do governo geral de Mem de Sá.

Esgotadas as condições operacionais exigidas pela expansão cafeeira, esta se estende pelo Vale do Paríba, onde 
os cafezais iam invadindo e ocupando as terras: subindo pelo rio, ocuraram a parte oriental da privíncia de são Paulo; seguindo sua vertente setentrional, estendeu-se pela região fronteiriça de Ifinas Gerais. Até o terceiro quartel do sécuio XIX, toda a área abrangida pela basia do Paraíba e regiões adjacentes foi ocupade pelo café, sendo o grande centro de produção cafeeira do período (PRADO JR, 1982, p. 161-162; CANo, 1981, x. 23-24)。A expansão do café pelo vaie do Paraíba se deu, notadamente, entre 1830, quando se verificou o estímulo ao grande plantio provocado pelo aumento dos preços do produto no mercado internacional, e 1860, quando as condições operacionais da cafeicultura não encontraram mais nessa região condições favoráveis para a expansão (CANO, 1981, p. 24-31; PRADO JR, 1982, p. 162-164).

Considerancio que a colonização do vale do Paraíba teve início velo avanço da frente agrícola, notadamente de um tipo de "ecoromia de subsistência", fica evidenciado que essa frente não estava provocada simplesmente pelo movimento centrífugo provccado pela economia mineira, mas era pressionada pelo averço cafeeiro. A medida que o café se expandia, pressionava a população engajada na produção de alimentos a buscar novas terras. Esta situação constituía uma frente de expansão que sempre caminhavà fa frente dos cafezais, "abrindo-Ihes o caminho"...

Foi com estas frentes que se defrontaram os Puri-Coroado, que habitaram o vale do Paraíba em sua fronteira com Ninas Gerais, e os Kaingare que o habitavam em sua porção paulista. Contra estes dois grupos se dirigiu a "guerra ofensiva" de 1808 e 1809. A "desinfeç̧ão" destas terras dos indígenas pode ser aquilatada cela ordem ainda de 1809 de doação 
das terras a colono que quisessem plantá-las。 Uma vez que a guerra contra os índios só foi levantada em 1831, seria praticamente impossível terem ficado grupos remenescentes. Isto significa dizer que quando houve a expansão całeeira propriamente dita, aqui também não foi enccntrada a menor resistência indígena. As terras já estavam desimpedidas de. obstáculos maiores.

Com a crise da economia cafeeira do vale do Paraíba, a expansão seguịu dois outros rumos: em direção à região oriental, penetrou na zona mineira e no Espírito Santo; a outra direção tomada invadiu o oeste paulista.

O avanço oriental do café, em Minas Gerais e no Espírito Santo, não encontrou nenhum problema em relação aos índios. Como estas. regiões eram habitadas por indígenas dos grupos Puri-Coroado e Botocudo, o extermínio e a expropriação de suas terras haviam se realizado ainda durante a primeira metade do século XIX.

o oeste paulista era uma região muito pouco povoada até fins do século XVIII, com pequenos núcleos de povoação destinados quase que exclusivamente a amparar os transportes e comunicações que se faziam entre são Paulo e Goiás. A o cupação econômica básica não ultrapassava os limites impostos pela produção de subsistência.

Nesta região, o café não encontrou as mesmas facilidades para sua expansão. Além dos ocupantes posseiros, pertencentes à frente expansionista nacional, o café teve que se defrontar com os índios Coroado que vivam nessa região e que não haviam despertado o interesse dos bandeirantes como mão-de-obra, por serem muito aguerridos e possuírem uma agricultura das mais primitivas (RIBEIRO, 1977, p. 101). 
As terras sobre as quais o café se estendia eram de dois tipos: as terras que já tinham um proprietário jurídico, e as que juridicamente não tinham proprietários - "terras devolutas" (SIIVA, 1980, p. 70). As terras consideradas "propriedade", poderiam se incorporar facilmente à expansão cafeeira; ou pela integração dos proprietários à cultura do café, ou pela venda da propriedade (Idem, p。7I)。

Com as terras devolutas, a questão era mais complexa, pois o fato de serem consideradas terras devolutas não significava que eram desocupadas.

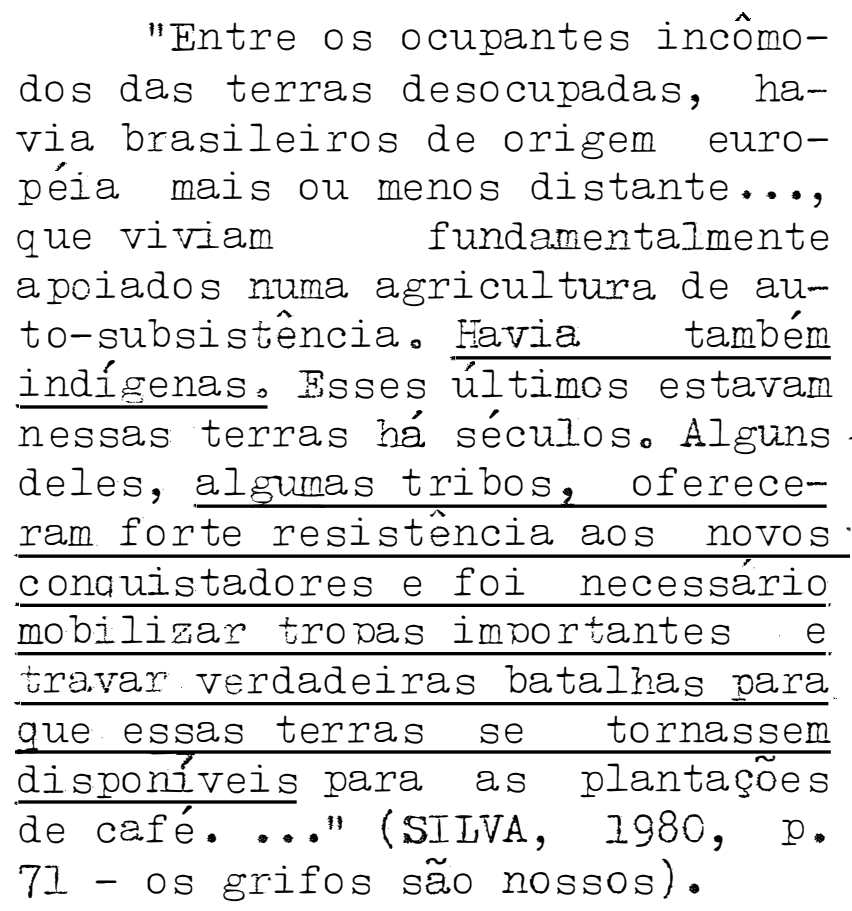

Esses conflitos, porém, não eram ainda generalizados, mas esporádicos e circunstanciais. Tanto é que muitas fazendas se instalaram na boca da mata, iniciando plantações de café, sem nenhum conflito com os Kaingang.

Os conflitos mais sérios só ocorreram no início do século XX, com as expedições religiosas, com as expedições científicas e, principalmente, com a construção da estrada de 
ferro "Noroeste do Brasil" (BORELII, 1984, p. 65-70; CARVAIHO, $1979, p \circ 60$ e 64-70).

Dessa forma, mesmo com todos os conflitos indígenas que estavam ocorrendo em praticamente todas as regiões do país, a economia mercantil-escravista nacional se transformava, sem que houvessem, ainda, se delineado discussões profundas sobre a questão indígena. A economia mercantil- escravista se transformou face as suas contradições internas, porém, a questão indígena só irá se conformar enquanto tal no início do século $X X$ 。

5.2. A Situação Indigenista no Centro-Oeste.

Como já se disse, o processo de ocupação econômica do centro-oeste brasileiro (Goiás e Mato Grosso) originou-se das penetrações de "bandeiras" paulistas, consolidando-se a ocupação no transcorrer do século XVIII, com a mineração.A expansão e posterior ocupação dessa região foi acompanhada, durante o século XVIII e boa parte do século XIX, por violentos conflitos com os grupos indígenas da região: em sua banda oriental com os Payaguá e os Guaikuru; mais à leste, com os Bororo, Kayapó, Xavante, Xerente e outros. Os primeiros dificultaram extremamente a navegação fluvial para Cuiabá; sendo que só em fins do século XVIII foi encontrada a forma de acomodação pacífica com os mesmos, através de um tratado de paz formal entre estes e a Coroa Portuguesa。

Com a decadência da mineração, ainda no século 
XVIII, as províncias do centro-oeste, ficariam ainda mais distantes dos centros desenvolvidos da Colônia, pela limitação drástica das migrações e do comércio. Tem início, então, um esforço contínuo no sentido de estabelecer comunicações regulares com a região amazônica e, em especial, com Belém, criando pontos de abastecimento ou núcleos de poveamento ao. longo do Araguaia, do Tapajós, do Madeira e do Tocantins (RAVAGNANI, 1978, p. 68-71)。

Com relação ao Mato Grosso, a expansão da colonização deu-se ao longo dos vales dos rios Madeira, Tapajós e Araguaia. Sua base econômica inicial era um desdobramento da expansão das frentes extrativistas da Amazônia, baseada na exploração das drogas do sertão. Essa expansão extrativista envolveu grupos indígenas numerosos que habitavam as margens dés tes rios e de seus afluentes (MOREIRA NETO, 1971, p. 133-134). o envolvimento dos grupos indígenas deu-se inicialmente sob a forma de engajamento forçado dos índios nas atividades produtivas; mas a esta seguia a prática da expropriação de suas terras e utilização dos remanescentes como mão-de-obra cativa. "(...) Alguns dos maiores grupos de Mato Grosso, durante o século XVIII, tentaram encontrar um ajustamento qualquer que lhes permitisse coexistir com a sociedade de tipo europeu que por ali se expandia。 A despeito, entretanto, da atitude assumida, todos foram drasticamente reduzidos em número, privados da posse de suas terras tradicionais e transformados em meros apendices eventuais da sociedade 
dominante。Outros grupos, talvez pelo fato de que a ausência de unidade interna os fragmentasse em segmentos autônomos, como os Bororo-Coroados e Shavante, apesar da intensa deropulação, conseguiram continuar existindo peIo mero recurso ao estado arredio ou hostil." (MOREIRA NETO, 1971, p. 135 - o grifo é nosso).

Seguindo os passos da expansão do extrativismo florestal, que no início do século XIX é acrescido da produção caucheira, ia se implantando ao lonธ̃o dos rios a navegação, fazendo surgir em suas margens núcleos coloniais destinados a servirem como entrepostos comerciais e pousadas para marreteiros, viajantes e missionários que continuamente subiam e desciam pelos rios (IARAIA e DA MATTA, 1979, p. 119-120). Os conflitos com as populações indígenas que habitavam os vales desses cursos d'água não se fizeram esperar, motivadas pela expropriação de suas terras, pela invasão dos territórios tribais e pelo incremento da prática dos descimentos.

Em apoio às populações que promoviam o "desenvolvimento" da região são restabelecidas as "guerras ofensivas" e a organização de bandeiras para reprimir os indígenas e possibilitar a expropriação de suas terras. Exxemplos disso foram as concessões feitas em 1811 e em 1825 ordenando "guerra ofensiva" aos índios da Província de Goiás e autorizando a organização de bandeiras contra os mesmos. Embora esses dois atos legais tenham sido ordenados pela Coroa para a Província de Goiás, pode-se dizer que afetou igualmente aos índios de Mato Grosso dada a similaridade de situações que os envolviam nesta mesma época.

A sequência da política e da prática iridigenista 
foi sempre a mesma: conflitos com os índios, seguida da organização de bandeiras ou expedições punitivas contra os mesmos. Essa situação, que continuava no início do século XIX, irá permanecer durante todo o período.

Em 1846, os planos do Governo Gomes Jardim incluiam a reunião de 16 aldeias existentes em Albuquerque e Miranda em 9 ou 10 aldeamentos, com a fusão de algumas que eram habitadas por população de uma mesma tribo. Refere-se ainda, à continuidade dos conflitos entre índios e a população regional, envolvendo os Bororo e os Kadiwéu (MOREIRA NETO, 1971, p. 141)。

Em relatório de 1848, o presidente da Província, Alves Ribeiro, anuncia o fracasso de algumas providências adotadas na pacificação e aldeamento de grupos hostis em Mato Grosso. Continuam as hostilidades envolvendo vários grupos tribais: Cabixi, Pareci, Bororo, Nambiquara, etc. Desse mesmo relatório consta que a pacificação dos Bororo havia sido realizada com a utilização de força armada contra os mesmos (Idem, ibidem).

Em 1851 continuam as hostilidades entre os indios e as frentes de colonização, envolvendo os Bororo-Coroados, os Cabixi e Barbado. Do mešsmo rélatório consta o desconhe cimento da população indígena que povoava os sertões entre os rios Xingú, Araguaia e das Mortes (IEVERGER, apud MOREIRA NETO, 1971, D。146)。

Em 1852 continuam os conflitos, envolvendo a cada ano outros grupos tribais. Referindo-se aos conflitos envolvendo os Bororo, Coroado, Cabixi e Mainbaré, o presidente da Província de Mato Grosso explicita que contra eles foram ado- 
tadas medidas mais drásticas, com a admissão do uso de expedições punitivas, particulares e oficiais, para cuja ação a província recebe o consentimento e recursos extras do governo imperial. Admite ainda, que as bandeiras deviam se esforçar ao máximo para aprisionar índios adultos, oferecendo um prêmio pelos que fossem apresentados vivos e sãos (MOREIRA NETO, 1971, p. 146-147).

Neste ano, é evidenciada outra prática indigenista adotada no Império: a utilização de grupos indígenas, geralmente inimigos, para a repressão a um outro srupo tribal, que dificultava a colonização. Esta ação ocorreu contra os índios Kadiwéu, que mantinham relações amistosas com a população regional, mas tinham voltado a agir na fronteira Brasil-Peraguai. O presidente da Província de Mato Grosso ordena o aldeamento do grupo, nomeando para tanto um missionário capuchinho, auxiliado por tropas do Comando Geral da Fronteira do Baixo Paraguai, mas:

"(...) Caso, ainda assin, os Kadiwéu resistissem ao internamento em aideias, índios Terena e Chamococo, tradicionais inimigos daquêles, deveriam ser concentra dos em seus territórios para neutralizá-los ou, eventualmente reprimir suas correrias. (...)" MOREIRA NETO, 1971, p. 147).

Em 1860 continuavam as hostilidades dos Bororo-Coroado no alto curso do rio são Lourenço. As tentativas de pacificação e de cateçuese foram abandonadas e o governador adota outro tipo de ação: destacamento de tropas permanentes para conter e neutralizar os índios e possibilitar a ocupação definitiva das áreas por eles habitadas:

"Para conter os ferozes e indo- 
máveis Coroados, que vagueiam pelas margens do 5ão Iourenço superior, e pelas estradas de Goias e Piquiry criou o meu antecessor um destacamento nas margens do dito rio, no ponto que conflue com outro caudaloso. Se prosperar o destacamento, e se se conseguir domar aquêles índios que tanto dano nos causam, e trazem os moradores de em tôrno em sobressalto, por serem essas terras salubres, fertilíssimas e com bôa navegação." (AIENCASTRO, apud MOREIRA NETO, 1971, p。150).

É interessante notar que quando voltavam a surgir problemas político-militares, a política indigenista do império passava a intensificar o aliciamento das populações indígenas. A defesa das fronteiras, a segurança nacional, passaram a adquirir notável proeminência. Essa situação passou a ocorrer em 1865, quando o Paraguai invadiu o Brasil e todo o esforço das autoridades passou a ser de cooptação dos grupos indígenas fronteiriços (CARVALHO, 1979, p. 44).

"(...) A necessidade de defender as fronteiras implicava, numa região parcamente povoada e onde - Índio representava uma fôrça de trabalho essencial, no aceleramento dos contatos com populações indígenas arredias ou mesmo hostis, com vistas a sua eventual utilização no conflito, ou, pelo menos, sua neutralização como elemento útil às fôrças invasoras. (...)" (MOREIRA NETO, 1971, p. 159-160).

Encerrada, porém, a guerra e não sendo mais necessária a continuidade de "alianças" com os indígenas, a ação 
indigenista volta a ser a mesma dos aros anteriores conflito: hostilidade, repressão armada, expropriaça de terra, extermínio...

Nessa mesma época, novas frentes econômicas determinaram o ativamento do aliciamento de índios como força de trabalho ou, quando isto era impraticável, de neutralização das resistências à ocupação dos territórios tribais: o desenvolvimento da economia extrativa da borracha, nessa época em pleno apogeu, atingia todas as áreas fronteìriças à região amazônica (CARVALHO, 1979, p.44).

Essa situação impunha a conjugação da política indigenista aos esforços de ampliação da ocupação de áxeas até então virgens. A este respeito, é ilustrativo o relatório do presidente da Província de Vato Grosso, em 1871:

"(...) Errantes pelos campos da Vila do Diamantino, também viven diversos índios ... Pareci. Nas Matas do rio Preto, Miacuco, AmoIar e Sant'Ana, há extensos seringais, de onde os próprios indios extraem o necessário leite para fabricarem as pulseiras de que usam, e algumas convenientemente examinadas têm dado provas de muito bôa qualidade; assim como informam de Montevideu, que uma pequena quantidade extraida do rio Preto, e vendida naquela praça, obteve ótimo preço nos mercados da Buropa. Tudo é s.erviço facílimo aos mesmos índios, que apenas tiveram uma ligeira direção, usufruindo vantagens imediatas da permuta por todos os gêneros de que precisam e à final virá a ser um rano de exportação pelo rio Paraguai, e uma fonte de riqueza pública co- 
mo a tem o Pará e Amazonas."

(CARDOSO JR., apUd MOREIRA NETO $1971, p .163)$.

Nas demais regiões da Província, continuavam os conflitos envolvendo Índios e as erentes de colonização. Ź interessante que, em 1851, os territórios situados nos vales dos rios Xingri, das Mortes e Araguaia ainda constavam como "sertão desconhecido"; em I87I, porém, o relatório do Presidente da Província, Cardoso Júnior, referia-se a conflitos envolvendo índios e os estabelecimentos agrários que se instalavan na região entre o vale do rio das Mortes e o Araguaia。 Os conflitos são atribuídos aos índios Coroado ou aos Cayapó, mas é muito possível que eram promovidos pelos Xavante, que já haviam ultrapassado o rio Aragraia, iniciamdo a ocupação desta região, existindo alguns indícios no próprio relatório:

"(...) Na região da estrada que liga Mato Grosso e Goiás, todo um trecho, do Sangrador até o Araguaia, é considerado inseguro e perigoso pelos ataques dos Coroados, grupo 'que não perde ocasião de perseguir-nos, matando pessôas e animais dos viajantes ou moradores. Nas proximidades desta cidade, pelos engenhos de serra acima, que estão mais ao sul, pelos estabelecimentos agráriosagrícolas de serra abaixo, para o mesmo lado, vivem hordas de índios aue se supõe pertencerem à tribo Caiapó aldeada em Santa Ana do Parnaíba, Os engenhos do Major João Capistrano, dos finados Lara e Sampaio, têm sido perseguidos, igualmente muitos moradores debaixo da serra. Após o assassinato e o incêndio, segue-se o roubo e nota-se que não abandonam as ferramentas, aparecendo muitas em 
Santa Ana, no respectivo aldeamen to.Além dêste fato que faz presumir que já conhecem o trabalho. agricola... existe um outro mais significativo, veio a ser o falarem. mais ou menos. o idioma portustrês, quando acaso são vistos。 (o..)" (CARDOSO JR。, apud MOREIRA NETO, I971, p. 163-164-o grifo é nosso)。

Pelo que se viu, pode-se inferir que a ação indigenista se revelava de muitas formas tendo em vista a heterogeneidade dos vários grupos indígenas e sua consequtente integração, assim como a vasta extensão territorial da Província (CARVALHO, 1979, p.46)。Essas situações foram, aliás, reflexão de um dos presidentes da província, João José Pedrosa, que em 1878 colocava o seguinte:

"(..o) Has, como atrair correntes da imigração, quando a distância, a falta "de segurança para os colonos, entre tantas hordas de índios bravios, apresentam-se como barreiras invencíveis para trazêlos até aqui? (...) o que cumprenos, conseguintemente, é remover primeiro os obstácilos que se antepõem.Suprima-se a distância, catequise-se o selvagem menos bravio, e afugente-se o mais indo mável, se tanto for preciso, e a colonização espontânea, única, profícua, virá com seus braços e capitais transformar essa terra ainda destêrro num Eden do Brasil. (。oo)" (A pud MOREIRA NETO, 1971 , D. 176)。

Esse relatório também revela outro dado significativo da ação indigenista da segunda metade do século XIX, que é a substituição dos aldeamentos, ou demais formas de a.tuação 
indigenista, objetivadas no estabelecimento de "muitas colônias militares nas proximidades dos lugares por onae vagueiam os selvagens" (Idem, p. 176-177), marcando claramente a política repressiva para com os índios。

A situação segue inalterada até 1879, quendo

○

presidente da Província, João José PEDPOSA, declara ter verdadeira repugnância contra as bandeiras, de caráter oficial ou particular, o que não o impediu de organizar "rondas volantes" para reprimir os grupos indígenas dos "territórios ameaçados". No relatório de 1879, assim se referiu a estas "rondas volantes", sua composição e, detalhe que chama a atenção, o auxílio do governo imperial à repressão contra os índios:

"(..) Disse-vos então que para preservar os lavradores de novas agressões, ao menos o quanto estava ao meu aicance, haria feito expedir ordem aos Comandantes de destacamentos, postados em diferentes lugares do interior para reprimir as incursões dos índios, - no sentido de serem organizadas rondas volantes, de acôrdo com os mesmos lavradores, afim de que, empregada a maior vigilância em todo o território mais ameaçado, se evitassem os assaltos de tão traiçoeiros inimigos, que aliás só acontecem de surpresa, fugindo logo que pressentem séria resistência。"

$$
(\ldots,)
$$

"(..) Compreendendo que tais rondas só podem ser bem executadas por homens apropriados, sertanistas, que, afeitos à vida do mato, não receiam as ciladas dos selvagens. Com pessoal nestas condições poder-se-iam organizar essas rondas, como serviço pecu- 
liar de una guarda rural, permanentemente mantida e bem estipendiada. Não tendo porém a Província suficientes recursos para tomar a si a despesa que demandaria tal serviço, lembrei-me de solicitar ao Govêrno Imperial o auxílio preciso, que ainda aguardo e podeis ficar certos de que sem essa guarda rural, constituida como fôrça policial da Província, mediante um regime peculiar, não será possível conter os selvagens, enquanto não forem estabelecidas colônias militares, organizadas especialmente para a catequese; (...)" (PEDROSA, apud MOREIRA NET0, 1971, ps。179 e 180-181)。

Com esta medida de criação das "rondas volantes" , ficava plenamente caracterizada a política anti-indígena do Estado, que no caso manifestava a intenção de conter as incursões indígenas, enquanto as colônias militares não fossem efetivamente criadas. Porém, mesmo essas organizações militares ou para-militares não surtiram o efeito desejado, uma vez que a ausência de transportes e comunicações representavam, aos olhos dos dirigentes provinciais, o maior empecilho ao desenvolvimento de Mato Grosso (CARVAIHO, 1979, p.49)。

As últimas décadas do século XIX em nada alteraram a política indigenista em Ma,to Grosso. Mruito ao contrário: intensificaram a organização de expedições militares contra grupos hostis; laços mais estreitos entre a política indigenista e os interesses dos proprietários de terras, nomeando muitos deles para o cargo de diretores de aldeias; finalmente, pela fundação de colônias indígenas, cujos resultados eram inteiramente negativos (Idem, ibidem, p. 49). Isto equivaile a dizer que a ação indigenista em Mato Grosso não se diferenciava em 
nada da que se realizou durante todo o período em estudo: extermínio de grupos indígenas, visando à "desinfecção" das terras para que se promovesse a colonização; caso ficassem remanescentes, e em conformidade com os interesses econômicos, uti lizá-los como força de trabalho cativa。

A situação indigenista em Mato Grosso só foi alterada no início do século XX, com a construção das linhas telegráficas pela Comissão Rondon e pela construção da Estrada de Ferro Noroeste do Brasil.

Com relação à Goiás, o processo de expansão econômica em direção ao Norte, pelos vales dos rios Tocantins e Araguaia, foi similar ao ocorrido em Mato Grosso, e, igualmente, provocou o envolvimento de grupos indígenas numerosos como os Carajá, Xavante, Xerente, além dos Krahô e outros Timbira.

Ao lado de uma prática indigenista que acompanha va as novas formas de ocupação econômica, a política indigenista da Província durante o império continuou a girar em torno dos aldeamentos criados, ainda, no século XVIII ou início do XIX, como São José de Mossamedes, aldeia Carretão e outras (MOREIRA NETO, 1971, p。190)。Os aldeamentos, porém, caracteri zavam-se por um irreversível processo de decadência: "não foram bruscamente extintos, mas condenados a uma lenta e triste agonia ..." (RAVAGNANI, 1978, p.73)。

A decadência dos aldeamentos vinha se verificando desde o final do século XVIII. Porém, no decorrer do século XIX a situação tendeu a um agravamento constante, até o momento em que começaram a ser transformados em "terras devolutas" e repassados para particulares, terminando assim a história dos aldeamentos que em última instância só serviram como mais 
um entre os muitos instrumentos utilizados para o extermínio de indígenas e para a expropriação de suas terras。 í interessante que se delineie, em suas linhas gerais, a decadência dos aldeamentos, a partir das fontes de inforração disponíveis.

Em 1819, O viajante POHL encontrou no Carretão apenas 227 índios, que reclamaram contra os maus tratos, pesados trabalhos e a extorsão a que estavam submetidoso Informa em seu relato que os Xavante "atemorizados Delo tratamento grosseiro, imprudente e mau dos administradores" voltaram à sua antiga vida nômade (Apud RAVAGNANI, 1978, p. 73-74).

Em 1824, CUNHA MATTOS encontrou nesse mesmo aldea- . mento 199 pessoas, informando que muitos índios haviam fugido e se unido aos que permaneceram arredios ao contato, transmitindo-lhes um terrível ódio aos brancos (A toud RAVAGNANI, 1978, p. 75)。

Im 1832, através do decreto imperial de 06 de juIho desse ano, foi ordenada a transferência dos índios do Carretão e de são José de Mossamedes e que as terras dos dois aldeamentos fossem vendidas em hasta pública (RAVAGNANI, 1978, p. 75). Muito antes, assim, da Lei de Terras, era iniciada a expropriação das terras indígenas, estabelecendo sua ocupação por agentes da colonização 。

Em 1835, o presidente da Província, JARDIM, apresenta o aldeamento de São José de Mossamedes como abandonado pelos índios Kayapó que haviam se retirado em 1832. A aldeia Carretão é descrita como decadente, reunindo pequeno número de índios Xavante e Xerente que se mantinham em paz, enquanto outros grupos desta "tribo" continuavam hostis (MOREIRA NETO, 1971, p. 190; RAVAGNANI, 1978, p。75).

Por volta de 1840, a situação dos aldeamentos é 
apresentada como de profunda decadência: na Aldeia do Carretão existiam pouco mais de 100 índios (Apud MOREIRA NETO, 1971, p. 196-197).

Em 1844, Francis CASTELAN esteve no aldeamento do Carretão e em Salinas. Sobre o Carretão informa que encontrou poucos índios Xavante e o aldeamerito em completo abandono. Em Salinas encontrou 180 habitantes, quase todos Xavante cristianizados, que aproveitou como remadores em sua expedição。Infor ma ainda que havia no. local um posto militar (Apud RAVAGNANI, 1978, p. 76 e 77)。

Em 1849, ao mesmo tempo em que tem início a orga nização de colônias militares ou colônias indígenas, que será tratada mais à frente, os antigos aldeameñtos nas regiões de ocupação mais antiga da Província estavam submetidos a condições de extrema decadência e penúria. É citada como exemplo a Aldeia Pedro III ou Carretão, onde existiam apenas uns 70 ou 80 indivíduos, classificados como "deșcendentes" das "Nações Chavante e Cherente" (MOREIRA NETO, 1971, p. 211; RAVAGNANI, 1978, p. 76)。

No relatório de 1850, de Olympio MACHADO, constam a existência de quatro aldeamentos: Carretão, Boa Vista, Pedro Afonso e São João do Jamimbu, reunindo índios Apinayé, KKrahô, Xavante, Xerente e Carajá, perfazendo um total aproximado de 4000 pessoas. Desse relatório constam outros dois dados interessantes: sobre a aldeia do Carretão, o presidente defende sua manutenção, justificando a necessidade de não despovoar o caminho entre a capital provincial e a vila do Pilar ficando, assim, os índios encarregados do abastecimento dos viajantes. Registra, ainda, uma referência à Aldeia dos Apinayé, próxima de Boa Vista e considerada o celeiro onde se abasteciam os habitantes civilizados do arraial (Apud MORIIRA NETO, 1971, p. 
213)。 Por essas passagens pode-se perceber claramente os dois fatos mais marcantes da política indigenista: o processo de expropriação das terras indígenas, só conservadas quando era de interesse a própria colonização; a utilização da força de trabalho indígena, ainda que por meios indiretos, em benefício dos agentes da expansão econômica.

Em 1851, nas margens do córrego Piabanha, próximo de Porto Nacional, em território Xerente, foi criada em 24 de junho a aldeia Tereza Cristina, mais tarde conhecida por Piabanha, onde se apresentaram 400 Xavante para serem aldeados (RAVAGNANI, 1978, p. 78).

Em 1852, Frei Raphael de Taggia afirmava existir em Piabanha aproximadamente 2139 Xavante e Xerente, não especificando o número de cada tribo (RAVAGNANI, 1978, p. 78).

Em 1855, foram todos os índios do Carretão e de São Joaquim do Jamimbú ordenados de transferência para a margem direita do rio são Patrício, onde eram ainda em número de setenta (RAVAGNANI, 1978, p. 76)。

Em 1857, o presidente da Província, Pereira da Cunha, relata a situação dos aldeamentos: 1) Aldeia de Pedro III ou Carretão, habitada por 60 índios, descritos como "descendentes dos Shavante e Sherente"; 2) Aldeia da Boa Vista, sob a responsabilidade do missionário Frei Francisco do Monte de São Vito, habitada por cerca de 600 índios Apinayé e Gradahú; 3) Aldeia de Pedro Afonso, sob a direção de Frei Raphael de Taggia, habitada por cerca de 200 índios Krahô - consta do relatório a ocupação da área dessa aldeia por 300 sertanejos vindos da Bahia e Piaú́; 4) Aldeia de Tereza Cristina com uma população de cerca de 3800 índios Xavante e Xerente; 5) Aldeia de São Joaquim do Jamimbú, habitada por índios de vários gru- 
pos, sendo os mais numerosos os Xavante, Carajá e Canoeiro consta, também, a ocupação crescente da área da aldeia por sertanejos, que já atingiam 205 habitantes. No mesmo relatório consta o processo de transformação dos antigos aldeamentos em povoações sertanejas, citando-se as Aldeias do Carretão e São Joaquim do Jamimbu, determinando-se a transferência dos indígenas remanescentes para outros locais; a causa da transferência İoi o "interesse criado pela presença de colonos nacionais na área" (PEREIRA DA CUNHA, apud MOREIRA NETO, 1971, p. 200-221 )。

Em 1859, o presidente Gama Cerqueira descreve os Índios de Goiás como vivendo "em uma condição verdadeiramente miserável" . Sobre o aldeamento de São Joaquim do Jamimbu informa que a população global era de 131 índios Xavante, Xerente e Carajá. Sobre a aldeia de Tereza Cristina, que era habitada por mais de 3000 indivíduos, indicando a possibilidade de conflitos potenciais no aldeamento, principalmente motivados pelo aldeamento de índios com tradições culturais diferentes, sendo alguns inimigos tradicionais, como o caso de 25 índios Guajajara atraídos do Maranhão. Consta, ainda, a utilịzação dos índios desse aldeamento como remadores no serviço de navegação do rio Tocantins. Sobre o aldeamento dos Apinayé, Krahô e Gradahu de Boa Vista, diz "nada sei absolutamente, porque nenhuma informação recebi do respectivo diretor em todo o decurso do ano p.p. ..." (GAMA CERQUEIRA, apud MOREIRA NETO, 1971, p. 221-224)。

Em 1861, além da transformação dos aldeamentos em vilas sertanejas, foi acelerado outro processo para extinção dos aldeamentos indígenas: transformá-los em colônias penitenciárias, que além de servir para alojar criminosos, mobilizá- 
-los-ia contra os índios - este assunto será tratado oportunamente.

Consta no relatório de AIENCASTRE de 1862, a existência de quatro aldeamentos em Goiás, sendo três no vale do Tocantins e um no Araguaia. No Tocantins localizavam-se: Pedro Afonso, Tereza Cristina e Boa Vista; no Araguaia: São Joaquim do Jamimbu. Sobre Boa Vista informa que existiam quatro aldeias Apinayé, uma Guajajara e outra Caracaty - totalizando uma população de 3220 indivíduos, dos quais 3000 são Apinayé, 100 Guajajara e 120 Caracaty: esse aldeamento estava sob a responsabilidade de Frei Francisco de Monte Vito. Sobre os aldeamentos de Pedro Afonso e Tereza Cristina (são tratados agrupadamente no relatório), informa que estavam aldeados Xerente, Xavante, Krahô, Canela e Guajajara; ambos os aldeamentos estavam sob a responsabilidade de Frei Raphael de Taggia, e compreendiam uma população total de 2000 índios Xerente e Xavante e 800 Krahô. Sobre São Joaquim do Jamimbu, também sob a direção de Frei Raphael de Taggia, informa que o habitavam mais de 200 Índios, entre Xavante e Carajá - informa, ainda, que a área do aldeamento já incluía mais de 300 colonos nacionais, além, de 7 militares (ALENCASTRE, apud MOREIRA NETO, 1971, p. 234-236)。No relatório consta a continuidade da política de instalação de presídios com a criação de dois desses presídios, denominados de "Amaro Leite", um às margens do rio das Mortes e outro na Ilha do Bananal, sendo solicitada a fundação de outro presídio na barra do rio Santa Tereza. Os presídios são justificados "a fim de completdr-se a linha de defesa contra os Canoeiros pelo lado do Tocantins" (Idem, p.236$-237)$.

Em 1863, Couto de Magalhães funda novo aldeamento, 
a que deu o nome de São José do Araguaia, para os Xavante e Carajá aldeados em Estiva e Salinas (Apud RAVAGNANI, 1978, p. 78).

En 1867, através do relatório do Desembargador João Bonifácio Gomes de SIQUEIRA, consta a existência de quatro presídios: presídio de Jurapensen, presídio de Santa Leopoldina, presídio de Santa Maria do Araguaia e presídio dos Martírios. Não há nenhuma referēncia importante sobre os aldeamentos, evidenciando-se a predileção pelas colônias militares ou pelos presídios, sempre sob o argumento de proteger a navegação pelos rios Araguaia e Tocantins, bem como proteger a colonização contra os índios (GONES DE SIQUEIRA, apud MOREIRA NETO, 1971, p. 242-243

No relatório de 1869 do presidente Ernesto Augusto Pereira, não consta nenhuma novidade quanto ao número dos aldeamentos e quanto a sua situação de decadência. Somente um dado é interessante: a mudança do nome do antigo aldeamento de são Joaquim do Jamimbu para São José do Araguaia.

A partir dessa data, os documentos disponíveis da Província de Goiás pouco falam dos aldeamentos, sendo que a ênfase passa a ser dada para os presídios ou para as colônias militares. Sobre os aldeamentos, a postura é de que deveriam ser transformados em vilas sertanejas, cumprindo plenamente a missão que tiveram, em conformidade com a legislação indigenista em vigor e com a política indigenista adotada em todo o país. Tomando uma análise de MOREIRA NETO, é possível entender os aldeamentos no quadro da política indigenista:

"... se pode concluir que o padrão geral de organização dos aldeamentos indígenas em Goiás não sofreu qualquer modificação 


\begin{abstract}
significativa, ordenando-se, segundo os propósitos de utilizar êsses aldeamentos como uma fase preliminar e necessária do processo de ocupação por coIonos nacionais das terras virgens da Província. Nesse contexto, o aldeamento indígena cumpre dupla finalidade, subordinadas àquele propósito: a pacificação de grupos indígenas hostis e sua posterior atração para êsses aldeamentos onde contribuirão com o seu trabalho para a implantanção de um mínimo de condições indispensáveis à posterior colonização da região.A chegada de colonos nacionais marca o início da decadência do aldeamento indígena que, paulatinamente, perde estas características e se transforma em povoação ou vila sertaneja..." (MOREIRA NETO, 197I, p. 245).
\end{abstract}

Enquanto os aldeamentos iam lentamente decaindo, nas áreas onde ocorria alguma espécie de atividade econômica era adotada uma política indigenista mais condizente com as necessidades impostas pelos interesses dominantes em jogo.

Assim, ainda no século XVIII, o gado iniciou a sua penetração no vale do rio Tocantins, fixando-se inicialmente na margem direita do rio e mais ao sul na região do Pau d'Arco. Além da expansão pastoril, as expedições geográficas começaram a percorrer esse curso d'água, procurando estabelecer ligações fluviais entre o norte e o sul do país, sendo determinadas ora pelo governo de Goiás, ora pelo do Pará。 De qualquer forma, o Tocantins permaneceu, então, como via de comuni- 
cação entre o interior e o norte, fazendo surgir em suas margens várias povcações e fortes, com a intenção de apoiarem e facilitarem a navegação, bem como servirem de entrepostos comerciais (IARAIA e DA MATA, p. 62 e 119-120)。

Essa expansão sofreu, no final do século XVIII, início do XIX, novo incremento, quando os vales dos rios Tocantins e Araguaia passam a integrar as frentes extrativas da seringa, castanha e babaçu. Começou, então, uma nova etapa na vida dos índios que passaram a ser "integrados" nos campos de interesse das comunidades regionais (Idem, p. 120).

Esse novo quadro que se apresentava em Goiás, com a ocupação da região norte, aos longos de seus grandes rios, era um incentivo para mais atrito com os silvícolas. Situação agravada pelas particularidades próprias que envolviam tanto os incígenas, quanto os colonos. Com relação aos índios, é preciso notar que a decadência dos aldeamentos fez com que a grande maioria dos "aldeados" tivessem voltado para as matas do norte da Província, carregados de ódio aos "civilizados" e instigassem os grupos que tinham permanecido arredios ao contato a continuarem resistindo a ele. Por parte dos colonos, a atividade comercial e agropecuária que animou a colonização do norte de Goiás, deu-se pela reunião de poucas famílias, enquanto isso, os antigos arraiais, inchados pela busca do ouro, estavam agora reduzidos a insignificante contingente populacio nal (RAVAGNANI, 1978, p。89)。

Em apoio aos colonizadores dessas novas frentes de expansão agro-pecuária, o governo colonial edita a Carta Régia de 05 de setembro de 1811, em que era aprovado o plano de estabelecimento das comunicações entre as Províncias de Goiás e Pará, bem como de colonização dos territórios situados entre 
as duas províncias. Com relação ao estabelecimento das comunicações, aprovava a constituição de uma sociedade de comércio, com todos os privilégios para implantação da navegação regular do Tocantins e o estabelecimento das colônias que se fizessem necessárias ao longo do rio. Em relação à política indigenista adotada nesse instrumento legal, foi de adoção da "guerra ofen siva" contra as tribos que impedissem ou dificultassem a colonização, ficando os indígenas como cativos pelo prazo de 15 anos ou enquanto durașse sua "ferocidade"。

Estava assim aberta mais uma etapa repressiva contra os índios, inclusive sacramentada legalmente. Porém, não parou com a ordenação da "guerra ofensiva", mas pela adoção da prática indigenista com base nas bandeiras, notadamente particulares, incentivadas pelo governo, que inclusive thes dava suporte econômico, além de garantir as vantagens como concessão de terras e posse de escravos índios que podiam explorar livremente pelo prazo de 15 anos ou mais (RAVAGNANI, 1978, p. 90; MOREIRA NETO, 1971, p. 193). A plena atividade das bandeiras era tão incorporada aos interesses que, em 1825, já sob o governo imperial, a decisão de no 210 do Ministério da Guerra se referia à nomeação de Comandante da força das bandeiras contra os Índios selvagens da Província de Goiás.

A ação indigenista contra esses grupos é a repetição do indigenismo em todo o império; organizam-se contra os índios bandeiras particulares, suportadas por incentivos e verbas públicas, apesar da condenação formal de tais expedições desde 1831. Essas invasões e ataques das bandeiras geraram em represália alguns ataques dos índios Xerente na região. Em conseqtência, a Câmara Municipal de Porto Nacional decidiu e aprovou a liberação de recursos para uma poderosa 
expedição ir às suas principais aldeias。 Essa expedição não teve resultados apreciáveis, porém demonstra a forma como era equacionada a questão indígena na Província de Goiás (MOREIRA NETO, 1971, p。190-191)。

As ações armadas contra os índios continuaram em 1838, não somente contra os Xavante e Xerente, mas agora também contra os Canoeiro, tidos como "indomáveis e ferozes" que atacavam desde o Município de São José do Tocantins até o rio da Cana Brava (MOREIRA NETO, 1971, p. 192)。

Nesse período verifica-se uma acentuada expansão da colonização de Goiás, Tocantins abaixo em direção às fronteiras do Maranhão. Essa expansão colonizadora, baseada na criação do gado, foi possibilitada pelas ações repressivas contra diversos grupos indígenas, como os Timbira, Krahô, Xavante, Xerente e Apinayé, etc. Entretanto, essa ocupação não se deu sem a resistência esporádica, mas constante, desses gru pos indígenas, que se mantiveram em atitude de hostilidade até - século XX. Entre as ações armadas que os índios mais sofriam, duas merecem destaques: as bandeiras e a utilização de grupos indígenas aliciados para dar combate a grupos "hostis". Sobre as bandeiras que se organizavam nessa época em Goiás, é interessante notar como os interesses econômicos dos particulares, notadamente de expropriar as terras indígenas e de transformar os remanescentes em força de trabalho cativa, caminhavam de braços dados com o apoio e o suporte econômico do Estado:

".. as bandeiras são organiza ções encarregadas de fazer a guerra ofensiva contra os indios, baseadas na participação, e acima de tudo, no suporte e conômico dado às ações por 
particulares. Para tornar possível ou desejável tal participação, o governo garante aos mesmos uma série de vantagens, entre as quais a concessão de terras e a posse de servos indígenas que poderão explorar livremente por quinze ou mais anos. (...)" (MOREIRA NETO, 1971, p. 193).

Outro aspecto significativo é a utilização de grupos indígenas aliciadọs para o combate a tribos consideradas "hostis". Exemplo disto foi a utilização dos Tapirapé e dos Carajá que foram atraídos pela promessa de recompensas posteriores, para atuarem contra uma aldeia de índios Xavante que existia abaixo de Salinas e que se acredita fosse o grupo responsável pelos ataques aos Julgados de Crixás e Amaro Leite (MOREIRA NETO, 1971, p. 195).

A principal preocupação das medidas adotadas com relação ao índio consistia, portanto, em "desinfetar" a área para que a economia pudesse se expandir sem encontrar impedimentos em sua frente. Fmbora a ênfase dada ao cativeiro indígena, é difícil pensar que essa frente tivesse intenção de integrar o índio como força de trabalho, pois, com exceção da agricultura, que ia pouco além da subsistência, a pecuária e o comércio quase não demandavam braços para o trabalho, e os que por ventura precisassem, eram recrutados nos decadentes aldeamentos que ainda mantinham "descendentes" indígenas disponíveis (RAVAGNANI, 1978, p. 93).

Por volta de 1840 tem início, também, a participação de missionários capuchinhos nas tentativas de atração de grupos indígenas. Ao lado da ação missionária, o governo provincial estudava medidas para fazer face aos grupos indígenas 
considerados "hostis", alimeritada nos propósitos explicitados no relatório do presidente da Província, Santos Azevedo, em 1842:

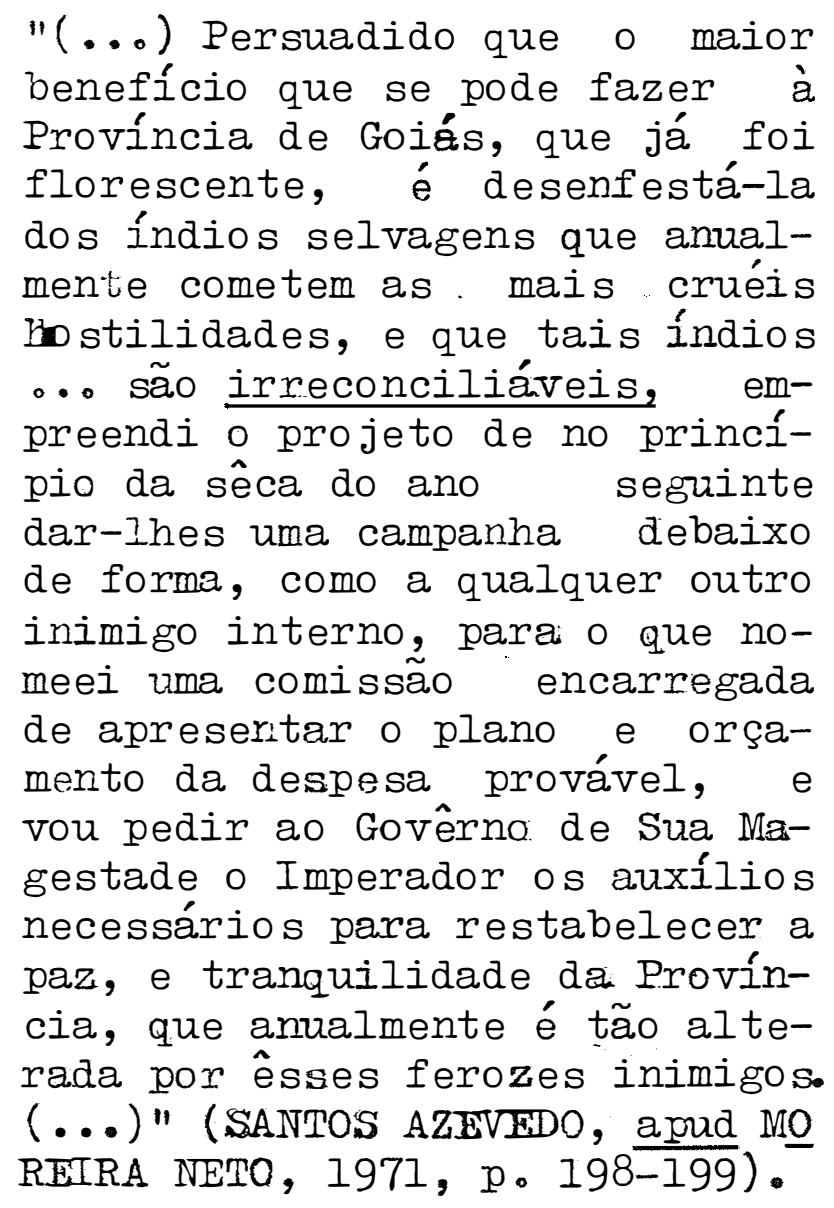

Um ano axós a aprovação do Regulamento de 1845, o presidente da Província de Goiás, Ignácio Ramalho, promoveu uma mudança significativa na política indigenista da província. Em primeiro lugar, fez críticas incisivas à instituição de bandeiras e outras atividades do gênero, dado que as expedições punitivas eram pouco eficazes e estimulavam ainda mais a resistência do indígena. Em segundo lugar, propunha una reformuląão dos métodos e formas de ação prática para o relacionamento com os grupos indígenas da província:

"(...) Para conseguir-se a civilização dos indígenas, o mé- 
todo que me parece mais pacífico é o estabelecimento de Aldeias nos lugares em que êles mais frequentemente habitam; destarte irão se convencendo lentamente de que a raça civilizada não quer a sua destruição, mas antes o seu bem estar. Criaram facilmerte necessidades que os obriguem à vida sosial onde sòmente poderão satisfazêlas。 Este sistema é preferível ao que se tem ordinariamente empregado, que consiste em pretender pela fôrça submetê-las ao estado de sociabilidade. Não atribuo a ferocidade dos indígenas tanto à índole, e costumes bárbaros, que neles se observa, como às bandeiras, e outros atos de violência que se tem empregado com o fim de chamá-los à sociedade pelo terror. (...)" (RAMAIHO, apud MOREIRA NETO, 1971, p. 204).

Unida à proposta de aldeamento, o presidente RamaTho, também propôs uma reforma nos princípios e objetivos ào sistema de aldeamento até então adotados:

"(...) Tenho refletido que o estabelecimento de Aldeias em lugares muito distantes daqueles em que os Indígenas fazem sua efetiva residência, arém de muito dispendioso, não pode prosperar. Não se pode empreender com sucesso a deslocação de uma horda de Selvagens do lugar em que se acham estabelecidos, e conseguir-se dêles uma mudança rápida de costumes, e sujeitá-los a um trabalho regular, quando outros são os seus hábitos. Julgo pois que a fundação 
de aldeias nos lugares em que êles estão habituados, para que gradual e insensívelmente adquiram necessidades sociais será o melhor sistema a adotar e que terá os melhores resultadoso (...)" (RAMALHO, apud MOREIRA NETO, 1971, p. 201).

Durante o governo de Ignacio Ramalho em Goiás, a ação indigenista deslocou-se do Tocantins para o Araguaia, onde ordenou o estabelecimerto das primeiras colônias militares ou indígenas ao longo desse rio: seus objetivos eram de proporcionar a civilização dos indígenas e "os meios de realizar-se a já conhecida navegação dêste rio" (Idem, p.203).

o primeiro grupo aldeado nessas condições foram os Carajá, sendo que um grupo foi aldeado em Jamimbu e outro nas margens do Araguaia.

Na mesma época, os missionários capuchinhos trazidos a Goiás para o trabalho missionário entre índios, desenvolveram seus esforços nas áreas onde mais se concentravam núcleos pioneiros de colonização, isto é, nos vales do Araguaia e Tocantins. Na região do Tocantins o trabalho missionário estava entregue ao Frei Francisco de Monte Vito, que conseguia bons resultados com índios aldeados em Boa Vista do Tocantins. Para a região do Aragraia, foi enviado o capuchinho Frei Raphael de Taggia, que fundou a Missão de Santa Maria do Araguaia (MOREIRA NETO, 1971, p. 205).

A ampla movimentação de colonos ao longo do rio Araguaia e os vários projetos de estabelecimentos pioneiros oficiais ou particulares, tiveram uma influência determinante sobre os indígenas, facilitando e tornando quase necessários os contatos entre as frentes pioneiras e os índios. Os Carajá, 
assim, logo são atraídos para a missão. Logo depois, o presidente da Província dá notícias de um grupo de índios Zavante que apareceram em Salinas "pedindo paz" ( $I d e m, p .206$ )。

seria, porém, muita ingenuidade pensar que o regulamento de 1845 e a política adotada pelo presidente da Província de Goiás, Ignácio Ramalho, tinham reais intenções de proteger a população indígena. Na verdade, deram-se num momento em que as frentes de expansão tinham perdido seu ímpeto inicial, uma vez que já dominavam a necessária parcela do território indígena. o que precisavam agora era de maior número de trabalhadores e paz para que pudessem explorar, em toda a plenitude, as terras que haviam conquistado (RAVAGNANI, 1978, p. 97). \$ituação esta que pode ser adequadamente apreendida pelos relatórios acima citados. Breve período, porém, durou essa situạ̃̃o 。

Fin 1848, assumiu a presidência da Província de Goiás, Pádua Fleury, que teoricamente repetiu os argumentos em defesa do método de ação indigenista proposto por Ramalho. Na prática, porém, a ação de criadores de gado e proprietários de terras nas regiões que vinham sendo abertas à colonização, forçava o deslocamento de vários grupos ináigenas de suas terras de ocupação imemorial a pretexto de que essas terras eram essenciais ao progresso da colonização.

Em relatório do presidente da Província, Pádua Fleury, de 1848, vários aspectos da prática indigenista adotada estão expostos e justificados. O primeiro deles é a continuidade do processo de expropriação das terras indígenas, sendo transferidos de seu habitat os índios Krahô das margens do rio Farinha para a região do rio do sono. A tarefa de retirada dos índios foi confiada a Frei Raphael de Taggia, "convencido ou 
aliciado pelos fazendeiros de Carolina ..." (MOREIRA NETO, ... 1971, p. 208)。A justificativa do presidente FLEURY, era a expressão direta e sem disfarces dos interesses dos colonos da região, conforme se pode evidenciar pela passagem abaixo:

"... não só porque êstes índios onde habitavam causavam dano às fazendas vizinhas com reiterados furtos, como também porque a fundação desta Aldeia no lugar indicado favorece a abertura da estrada que há tempos se projeta de Vila do Pôrto Imperial pela margem direita do Tocantins, a Carolina, facilitando por êste meio as comunicações, encurtam-se algumas léguas e a própria navegação pode receber socorros desta aldeia." (FLEURY, apud MOREIRA NETO, 1971, p. 208-209).

A transferência dos Índios Krahô não só evidencia a continuidade do processo de expropriação das terras, como também o uso dos indígenas para ampliar a abertura das frentes pioneiras, pela abertura de estradas e apoio à navegação. Porém, muito mais que o indicado acima, a transferência dos Krahô tinha outro objetivo: foram para aí transferidos com o propósito de forçar a resistência contra os Xavante e Xerente, cuja presença era constante na região, levando uma hostilidade até as vizinhançais de Porto Nacional. As intenções de opôr resistência pela presença de Guardas Nacionais na nova aldeia. Isso não impediu, porém, a continuidade dos ataques Xavante que chegaram mesmo a matar dois Guardas Nacionais estacionados na própria aldeia (MOREIRA NETO, 1971, p. 209-210).

Em 1849, porém, se completava a transferência dos 
Krahô do rio Farinha para o rio do Sono, que recebeu o nome de aldeia Pedro Afonsc, en homenagem ao Imperador.

Como bem observa MOREIRA NETO, a transferência dos Krahô, a justificativa ideológica do presidente da província, o uso de grupos tribais na abertura das frentes e na coação a outros grupos tribais, nada mais revelam que um traço característico da política indigenista do Império:

"... os bons propósitos com que, eventualmente, êste ou aquêle presidente de Província se apli cava à análise e solução dos problemas indígenas, eram inúteis ou, pelo menos, em larga medida inoperantes, devido à atuação sistemática de poderosos interêsses particulares que continuavam submetendo os indígenas a um processo geral de empobrecimento, desorganização social e marginalidade face à sociedade nacional." (Idem, $p$. 210)。

Com o governo do novo presidente da Província de Goiás, Eduardo Olympio MACHADO, entre 1849 e 1850, transparece um dos temas mais reiteradamente lembrados por administradores ou políticos regionais, revelador de outra faceta da política indigenista: a importância da força de trabalho indígena, inútil ou prejudicada pela resistência e hostilidade que opõem aos contatos com a sociedade nacional, mas que podem transfor mar-se em instrumento de riqueza e progresso da província, principalmente se se admite a abolição da escravatura negra e da impossibilidade da transferência de colonos europeus para a região. Para que tal objetivo fosse alcançado, não bastava a reunião dos índios em aldeias e o trabalho missionário. Era preciso integrá-los aos valores, formas de organização e nor- 
mas e técnicas da sociedade "civilizada", o que seria realizado pela criação de oficinas nas aldeias, pelo ensino das primeiras letras e pela contratação de pessoas capazes de treinax os índios nos ofícios mecânicos.

Em 1851, o presidente da Província A。J。da Silva Gomes, revelava uma ligeira tendência de retrocesso, afirmando que não acreditava que os índios pudessem ser imediatamente afastados de suas condições de vida tribal, "acostumados à independência de povos nômades...", mas pelo menos estando aldeados deixariam de fazer com que as "populações cristãs deixem de sofrer..." pelas incursões bárbaras e derramamento de sangue.

Até 1856, não houve nenhuma mudança significativa na política indigenista. Porém, nesse ano, foram feitos esforços para estabelecer contatos com grupos hostis; entre as tentativas consideradas importantes, uma foi dirigida à região do rio das Mortes, sob a direção de Frei Segismundo de Taggia, à procura de um grupo Xavante considerado hostil. A importância dessa expedição estava em pôr à mostra os principais traços da política indigenista: em primeiro lugar, demonstrou a rapidez com que se deslocava a frente de ocupação da sociedade regional, sendo necessário o controle das populações indígenas consideradas "hostis"; por outro lado, revelou a continuidade dos métodos usualmente utilizados, sempre prevendo o uso da força, a ponto da expedição ser organizada de modo a oferecer toda a proteção possível, com o uso de "Força de linha, paisanos e índios"; finalmente, a utilização de índios já contatados, no caso os índios pacíficos da aldeia do capitão Felipe "Whavante", para reforçar a expedição 。

A expedição localizou os Xavante, mas resultou num 
fracasso, pois gerou a hostilidade desses índios, resultando na morte de vários índios e soldados da expedição

(MOREIRA NETO, 1971, p。216-219)。

A partir de meados do século XIX, ao longo dos rios Araguaia e Tocantins, bem como de seus afluentes, a implantação de presídios e colônias militares, ao lado dos destacamentos que guarneciam as aldeias já fundadas, como Jamimbu, constituíram o traço dominante da política indigenista. A criação desse tipo de estabelecimento tinha por objetivo estancar as hostilidades dos grupos indígenas localizados nessas regiões, principalmente dos Xavante e Canoeiro, possibilitando. as condições para a efetivação da ocupação dessas terras.

Em 1857, o processo de transformação dos antigos aldeamentos indígenas em povoações sertanejas é acelerado, em muitos casos pelo Governo Imperial, como nos casos da Aldeia do Carretão e de São Joaquim do Jamimbu,- determinando a transferência dos indígenas remanescentes para outros locais, graças às pressões dos interesses criados por colonos nacionais na área (PEREIRA DA CUNHA, apud MORELRA NETO, 1971, p。221). Essas medidas afetaram diretamente os Xavante, Xerente e Krahô .

Provavelmente motivados por esse processo de expropriação de terras, que estava sendo promovido para possibilitar a ocupação das mesmas por colonos, têm reinício as hostilidades promovidas por índios. Em 1858, consta o ataque de índios Canoeiro zos arredores da Vila do Pilar; nesse mesmo ano, consta a presença de índios nas vizinhanças do Arraial de Santa Rita, não sendo registrados, entretanto, sinais de hostilidade, supondo-se que não fossem índios Canoeiro, mas Xavante que habitavam na margem esquerda do Araguaia, proxima- 
mente à foz do rio do Peixe, e iam às fazendas próximas a Santa Rita para abasterecerem-se e viverem à custa dos lavradores. Em 1859, são registrados outros incidentes, inclusive na Comarca de Porto Nacional, com ataques dos Canoeiro a criadores de gado da região do rio Maranhão (GAMA CERQUEIRA, apud MOREIRA NETO, 1971, p。226-227).

Foi surpreendente para a época a atitude pacífica tomada pelo presidente da Província, que adotou medidas preventivas e prudentes, contrariando as normas adotadas em situações similares:

"o.. determinavam que a guarni-
ção das regiões mais atingidas
por correrias de indios, refor-
çada por Guardas Nacionais, fi-
zesse a ronda das regiões mais
ameaçadas, procurando não só
localizar os grupos indígenas,
com a proibição formal de ten-
tar contra êles qualquer ação
agressiva, mas, também, pelo
contrário, portando brindes que
pudessem atraí-los ou convencê-
los a uma atitude mais pacífi-
ca." (MOREIRA NETo, l971,
227).

Eșa atitude pacífica em relação aos índios não passou, entretanto, de caso particular que dependia da disposição do presidente da província em relação aos índios. Tanto é asgim que em 1859, Aragão e Mello, volta a adotar uma polítí ca de oposição em relação aos índios, demonstrando uma animosidade mal disfarçada contra os mesmos e uma atitude sensível à adoção de medidas punitivas contra os grupos indígenas considerados hostis.

Sua atitude punitiva fica adequadamente caracteri- 
zada pelas medidas adotadas contra os Carajá e Carajaí que atacaram a missão de Santa Maria:

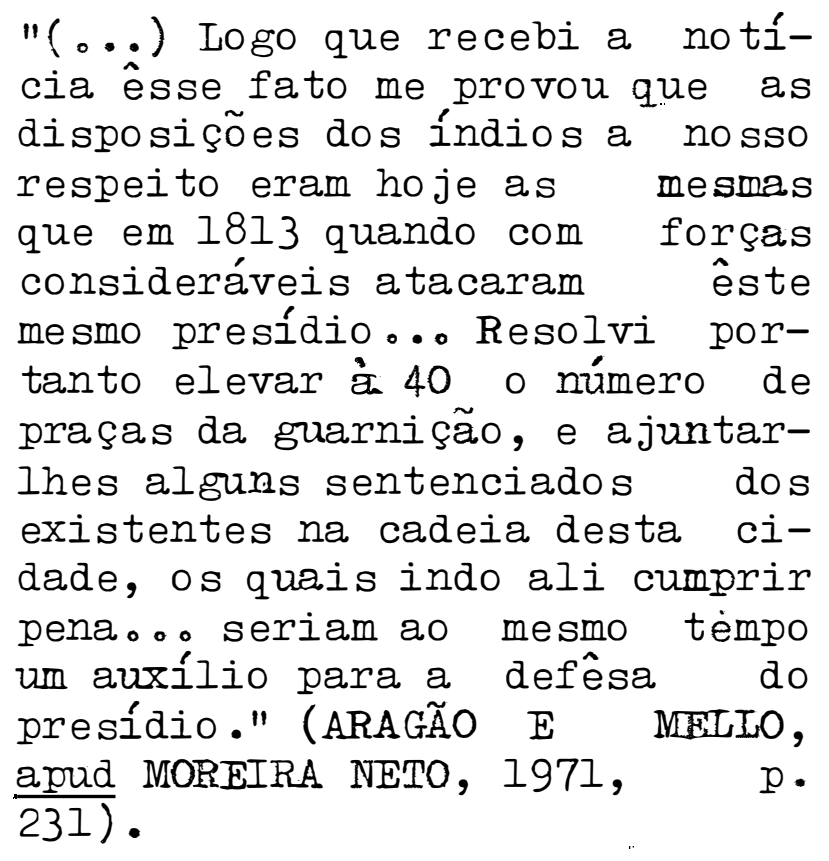

Se não bastasse o aumento da guarnição militar, a presidência da província adotou medidas mais eficazes contra os índios, como transformar as colônias militares ou inaígenas em peni.tenciárias para elementos indesejáveis, dispostos a tudo, inclusive de atuarem contra os índios.

As intenções de Aragão e Mello ficam mais claras pela atitude que tomou contra os mesmos Carajá que habitavam a Ilha do Bananal até abaixo de Santa Maria: "nomeei um comandante para Colônia de Santa Maria, com o propósito de iniciar uma ação punitiva contra os índios da área" (Apud MOREIRA NETO, 1971, p. 232).

O final da década de 1860 e a década seguinte, foram caracterizados por outro tipo de ação indigenista, de cunho integracionista. Já em 1869, o presidente Ernesto Augusto Pereira, expunha em seu relatório os propósitos da ação indigenista como instrumento de desenvolvimento agrícola do Estado 
pela aquisição de uma força de trabalho local e acessível, principalmente em vistas da eminente abolição da escravidão negra.

"( . o) Chamo tôda a vossa ateņão para êste ramo do eerviço público pelo duplicado benefício que a Província deve colher da civilização dos índios, obteremos milhares de braços para a agricultura, base da riqueza pública, e para outros trabaIhos úteis, e ao mesmo tempo teremos completo domínio nos excelentes matos, nas pingues pastagens e nos rios piscosos e navegáveis de cujo uso em outros tempos nos têm privado em parte por meio de suas cruéis atrocidades. Se quando havia a importação de escravos da Costa d'Árica já se tratava da catequése dos índios, hoje que felizmente cessou êsse abominável tráfico, e que é geralmente partilhada a idéia da emancipação dos escravos existentes, devemos com a maior solicitude envidar todos os esforços em pról da civilização dêstes infelizes que vivem errantes pelas matas。(...) Na província mesmo existe o remédio ao mal que ela sente, da falta de braços; sim, aí estão mais de 20000 índios selvagens, que civilizados serão bons colonos. Firme nêstes princípios tenho constantemente empregado os meios de que dispõe a Província para chegar ao fim desejado." (AUGUSTO PEREIRA, apud MOREIRA NETO, 1971, p. 246-247)。 
Em 1872, já estava em plena realização o projeto indigenista implantado em Leopoldina por Couto de Magalhães que pretendia criar um centro formal de educação de índios com vistas a sua integração na sociedade nacional e sua eventual utilização no trabalho de pacificação e assistência a outros grupos tribais. Ao mesmo tempo, Couto de Magalhães dava início a uma política de organização de colonização no vale do rio Araguaia, com a criação da Companhia de Navegação a Vapor desse rio, e nessa colonização pretendia empregar os indígenas "que mostram muita aptidão e se vão habilitando para a vida social..." (Apud MOREIRA NETO, 1971, p. 247).

Deve-se observar que a atividade indigenista em Goiás, ao lado do serviço geral da Diretoria Geral dos Indios, foi desenvolvida no Araguaia através de um serviço especial: o Serviço de Catequese no Vale do Araguaia, criado e dirigido por Couto de Magalhães e associado aos planos e objetivos que visavam ao desbravamento, à ocupação e à colonização dessa região, através da Empresa de Navegação do Rio Araguaia (MOREIRA NETO, 1971, p. 252).

Sobre o Colégio Izabel, consta que em 1871 já se encontravam ali internados 21 indígenas de ambos os sexos, dos seguintes grupos tribais: Carajá, Kayapó e Gorotire. Esses indígenas se dedicavam ao estudo das primeiras letras, assim considerado pelo presidente Antero Cícero de ASSIS:

".. o que não só é necessário para mudar-lhes os hábitos, adoçar-lhes os costumes, como dá tempo a que se preparem as oficinas dos trabalhos, que também se devem ocupar. (。o)" (Apud MOREIRA NETO, 1971, p。247)。

tinteressante observar uma passagem do relatório 
desse mesmo presidente, em que o recrutamento de alunos índios para o Colégio era feito sraças à prática de "resgate" dos índios Kayapó, que embora fosse oficialmente proibida, era justificada como "prática usual desses índios em suas sortidas contra outros grupos do Araguaia" e estimulada por particulares e pelos próprios indigenistas e missionários (MOREIRA NETO, 1971, p. 251). Consta que em 1875 o Colégio tinha 39 alunos de ambos os sexos e das tribos: Cayapó, Gorotire, Tapirapé, Guajajara, Xavante, Pivóca e Carajá。

Muito embora a caracterização acima possa dar margem a uma política indigenista amistosa, é importante que se destaque que essa "amistosidade" se dava no plano nominal, pois na prática a política indigenista continuava com os mesmos elementos de incompreensão e violência que sempre a definiram. Exemplo disto foram as ocorrências registradas no Aldeamento Shambioá, constante do "Relatório da Diretoria Geral dos Indios de Goiás", em 1864: o desaparecimento de sacas de sal sob a guarda do missionário Frei Savino da Ramimi foi o pretexto para a adoção de medidas violentíssimas contra os índios Shambioá que haviam sido recém pacificados, praticadas pela guarnição da aldeia a mando do missionário, assim registrado:

".. do qual resultou a morte de cêrca de 30 índios e outros tantos feridos, sendo a causa de tão desgraçado acontecimento, segundo a informação do dito missionário, a relutância dos mesmos índios em restituírem 100 sacas de sal que haviam fun tado, os quais pertenciam à prrpresa de Navegação do Rio Araguaia e achavam-se em depósito sob a guarda do referido missi- 
onário. De conformidade ccm o que $V$ 。 Exa. ordenou-se no supra citado ofício, foram expedidas por esta Diretoria as mais terminantes recomendações e aos demais da Província afim de que de nenhum modo se empresue 0 uso da mão armada contra semelhante gente." (Apud MOREIRA NETO, 1971, p. 248)。

Outro exemplo dessa política indigenista violenta está na fundação de presídios e colônias militares nas áreas menos povoadas de Goiás, especialmente nos vales dos rios Araguaia e Tocantins, tendo uma grande importância nas relações entre os vários grupos indígenas a partir de 1849. A importância desses presídios na política indigenista do Estado pode ser vista por uma passagem do relatório do presidente Aristides de Souza SPINOLA, de 10 de março de 1880, em que reproduz inclusive a visão do Ministério do Império sobre a questão:

"O aviso de 29 de janeiro de 1849, expedido pelo Ministério do Império mandou fundax presídios nas margens do Araguaia para proteger a nævegação. a Ministro, que o firmou, disse: - A Província de Goiás possui grandes elementos de riqueza, que devem ser fecundados rela ação administrativa, para que ela acompanhe as demais do Império no seu crescimento e prosperidade. Para dar impulso e desenvolvimento às suas forças industriais acanhadas por sua posição central, e conseguinte dificuldade na saída de seus produtos, nada poderá contribuir tão eficazmente como melhoramentos da sua navegação fluvial pelo Araguaia e Tocantins. 
- E adiante: - Não ignora o Govêrro que as dificuldades naturais, que tanto embaraçam o livre curso dos rios de que se trata, são ainde agravadas pela absoluta falta de recursos em suas desertas margens, só povoadas de féras, e de Índios, tão. selvagens como as mesmas féras. Em vão, pois, se tentaria meIhorar a sua navegação, sem que, ao mesmo tempo, se promovesse a fundação de povoações nos pontos mais arriscados de suas margens, pois que só assim poderão empreender-se as suas obras, e acharão os viajantes os recursos de que carecem em tão penosa viagem. Não podendo, porém, ocorrer-se à fundação de povoações em semelhantes lugares, senão por meio de quartéis ou presídios..." (SILVA GOHES, apud MOREIRA NETO, 1971, p. 256 - o grifo é nosso)。

Assim, em 1850 foram fundados às margens do Araguaia, os Presídios de Santa Leopoldina e Santa Isabel; em 1851 foi restaurado o de Santa Maria e o de Santa Isabel foi deslocado para a margem esquerda do mesmo rio, ficando com o nome de Santa Isabel do Morro; em 1853, os presídios do Aragraia foram transferidcs para o Tocantins, para servirem de apoio ao acesso da população aos sertões de Amaro Leite; em 1855, restabeleceu-se o presídio de Leopoldina, assentando-o junto ao Lago dos Tigres, à margem esquerda do rio Vermelho; em 1856, este foi novamente transferido para a povoação de Leopoldina。

No relatório de SPINOLA, de 1880, constam também os vírios presídios do Araguaia e do Tocantins. No Tocantins : 
presídios de Santo Antônio, fundado em 1875, e o de Santa Bárbara, fundado na mesma data。 Os do Araguaia eram: Jurúpensem e Santa Maria do Araguaia (Apud MOREIRA NETO, 1971, p. 260)。 Malgrado a disposição de alguns presidentes da Província em melhorar as relações ccm os índios, no transcorrer de todo o século, a política indigenista adotada contimuou a ser agressiva e, em consequência, a hostilidade era generalizada em todas as áreas de colonização. Essa situação de agressividade era tal que o presidente a considerou como uma barreira à integração do índio, propondo sua substituição por colônias agrícolas. Entre os motivos para recusar as guarnições militares estavam as constantes hostilidades para com os índios:

"(..) Representei ao Govêrno Imperial fazendo sentir a vantagem da substituição dos presídios por colônias agrícolas ... A catequese do selvagem esbarra em tais estabelecimertos, e não progride; o soldado trata - indígena como uma fera. Ainda há pouco chegou-me notícia de que um comandante do presídio, sem razão alguma, sem agressão ou provocação, transportara-se para a margem esquerda do Araguaia e aí destruira as pequenas choças de alguns selvagens. ( ...)" (IEITE MORAIS, apud MOREIRA NETO, 1971, p。2 $\overline{68-269)}$.

A. hostilidade era tamanha que em 1880 o presidente Aristides de Souza SPINOLA a expõe em seu relatório:

"(...) $V \cdot E x \cdot$ não imagina quantas atrocidades a nossa gente, ainda modernamente, tem feito contra os índios, as 
quais não são dadas à pủ̇licidade e dificilmente são conhecidas da presidência。 0 maior obstáculo para a catequése não é o ódio dcs indígenas contra os cristãos, é o ódio destes contra aquêles". (Apud RAVAGitANI, 1978, p. 97-98)。

Para finalizar a política indigenista durante o período, é importante lembrar as duas circunstâncias que a geraram: as estreitas relações entre os interesses privados e a política indigenista; è as características da ação indigenista do Império, de tolerância, incentivo e até autorização para expedições armadas.

A influência de interesses privados sobre a política indigenista foi demonstrada em várias passagens aqui tratadas e que podem ser adequadamente exemplificadas por três situações: a primeira, quando em 1852 o presidente da Província de Mato Grosso, Leverger, autorizou a um fazendeiro do Distrito de Mato Grosso a aldear os índios Guarayu, que habitavam as proximidades de suas terras à margem direita do Guaporé, sendo dado ao fazendeiro todo o apoio e os meios necessários para a atração dos índios (MOREIRA NETO, I971, p. 148); a segunda, quando em 1881 o presidente da Província de Mato Grosso, Leite Galvão, promoveu a mudança de habitat dos índios Bororo-Cabaçaes, nomeando Diretor da nova aldeia o fazendeiro responsável pela transferência, João Alves Corrêa, concedendo ao mesmo direito para que os índios fizessem diversos serviços (Idem, p. 184);o terceiro exemplo, deu-se em 1848 com a transferência dos índios Krahô de seu habitat, sendo para tanto utilizado o missionário capuchinho encarregado da civilização dos mesmos, sendo salientada a conivência do missionário e, 
evidentemente, do governo provincial, para com os interesses representados pelos proprietários fundiários. Esses três exemplos ilustram adequadamente a forma como os interesses privados se sobrepunham aos interesses das populações indígenas. Nem é necessário exemplificar as situações em que se deram as bandeiras de particulares ou oficiais contra os índios, dada a quantidade de situações já relatadas.

A ação indigenista do governo imperial já foi relatada com detalhes anteriormente, basta recordar que suas preocupações básicas eram a de possibilitar a expropriação de terras, tendo apoiado financeiramente diversas bandeiras, mesmo quando a legislação formal era proibitiva nesse sentido, e a conivência para que a força de trabalho indígena fosse amplamente utilizada, inclusive enquanto cativa, nas mesidas situações. 
6. OS XAVANTE NO SÉCULO XIX

Anteriormente, tratou-se dos Xavante e dos processos que os levaram a ocupar a vasta região compreendida desde o rio São Francisco até o Araguaia, no quadrante formado entre $48^{\circ}$ e $51^{\circ}$ meridiano e $12^{\circ}$ e $16^{\circ}$ paralelo (RIBEIRO, 1977, P.65; GIACCARIA e HEIDE, 1972, p. 14). Nesse habitat, primeiro sofreram as incursões das bandeiras, depois alguns grupos foram aldeados e outros continuaram a manter uma atitude - de hostilidade para com os agentes das frentes de expansão da sociedade nacional.

No transcorrer do século XIX a situação desse grupo tribal foi de extrema complexidade. Dos Xavante aldeados, uma parte considerável retornou gradativamente à sua vida de refúgio, voltando a ocupar os territórios tribais tradicionais, em virtude do tratamento a que foram submetidos, aos maus tratos e às moléstias que acabaram contraindo do contato (GIACCARIA e HEIDE, 1972, p. 22; RIBEIRO, 1977, p. 65; RAVAGNANI, ... 1978, p.74)。Um pequeno contingente populacional continuou, porém, a viver nos aldeamentos goianos, encontrando-se referências sobre eles na maioria dos relatórios dos presidentes 
da Província e de outros documentos, no transcurso de todo o século XIX, conforme se evidenciou em capitulo precedente.

A parcela mais significativa do contingente populacional Xavante, porém, continuou a conservar, no transcorrer de todo o século XVIII e, principalmente, no XIX, uma atitude de distância e franca hostilidade para com os "brancos". Situação esta reforçada pelos indígenas que abandonaram os aldeamentos oficiais.

A medida que passa a ocorrer a ocupação econômica dos vales dos rios Tocantins e Araguaia, representada inicialmente pela expansão pecuária, depois pela ampliação- da- economia extrativista amazônica, e, finalmente, pela implantação da navegação e comércio fluvial ao longo dos principais rios "do centro-oeste, com a instalação de inúmeros projétos e frentes de colonização, a situação desses índios volta a complicar. Por um lado, os conflitos passaram a se generalizar, envolvendo os Xavante e as frentes de colonização, ao longo de todo o território tribal que foi sendo ocupado. Ao conflito, seguiu-se a retomada das guerras ofensivas, das expedições punitivas ə das bandeiras, objetivando o extermínio dos grupos indígenas que impediam a expansão da colonização e a expropriação das terras em que esta ia se implantando.

Assim, ao longo de todo o século XIX, os conflitos e os confrontos envolvendo os Xavante ocuparam grande parte da história da Província de Goiás. Ao mesmo tempo, na medida em que as frentes de expansão passavam a ocupar parcelas do território tribal, outros grupos Xavante iam sendo desalojados e buscavam as regiõos ainda não atingidas pelas frentes de expansão econômica nacional. Inicialmente se alojaram na margem direita do rio Araguaia. Curta, porém, foi a estada, pois a 
colonização aí também chegava, provocando novos conflitos, novas bandeiras e, para os Xavante, ou o extermínio ou a fuga... Assim, ultradassaram o rio Araguaia, indo alojar-se no território compreendido entre os rios Aragraia e das Mortes, em terras matogrosaenses, da Serra do Roncador. No novo habitat tiveram, primeiro, que se confrontar com as tribos indígenas que o habitavam, depois, novameate foran atingidos pela colonização em constante processo expansionista。

Se não bastasse a complexidade da situz̧̧ão em si mesma, há sobre os Xavante no século XIX uma questão teórica bastante polêmica e que se refere à origem desse grupo tribal. Para os autores que tratam dos Xavinte, estes formavam uma única nação ou un único grupo tribal, juntamente com os Xerente - e eram denominados de Akwên. 0 motivo da separação foi que um grupo de Akwên, que denotava maior aversão para com os civilizados, deslocou-se para a margem esquerda do rio Tocantins e depois para o Araguaia, acabando por se estabelecer no rio das Mortes, passindo a ser conhecido como Xavante. Outro srupo Akwên permaneceu no habitat tradicional, mostrando maior disposição para conviver com os civilizados, passando a ser conhecidos como Xerente (RIBEIRO, 1977, p. 64-68; RAVAGNANI, 1978, p. 99-107; RIBEIRO, 1983, p.73-74).

Pelos relatórios oficiais e relatos de viajantes e outros documentos históricos até agora tratados, é. muito provável que esta explicação teórica das origens desses grupos tribais, propagados de forma absoluta péla produção antropológica e etnográfica brasileina, não passe de mais uma mistificação altamente elaborada destes ramos das ciências numanas. As evidências históricas disponíveis não permitem esta inferência, o que se procurará dernonstran oportunamente. 
Segue-se a abordagem dos Xavante em Goiás, depois em Mato Grosso e, finalmente, será discutida a explicação da origem desse grupo tribal.

\section{I. Os Xavante em Goiás no Século XIX}

Como foi visto, com o apogeu da economia mineira do século XVIII, a política indigenista da Província de Goiás centrou-se no aldeamento dos principais grupos tribais. A primeira grande "pacificação" dos Xavante realizou-se nessa época, sendo construída para aldeá-los a aldeia de Pedro III ou Carretão. Neste aldeamento foi concentrado o principal contingente populacional Xavante, com cifras que variam de mais de dois mil a oito mil Xavante, conforme a fonte de informação (Ver RAVAGNANI, 1978, p. 63 - nota 38).

Pouco duraram os pomposos empreendimentos levados a cabo nos aldeamentos, cujo apogeu se limitou a duas décadas - de 1770 a 1790 - indo junto com os demais Pedro III ou Carretão. Essa situação foi provocada pela decadência da mineração e pela ausência de medidas a curto prazo que incrementassem a economia da província。

"A queda da produção das minas fez mudar radicalmente a orientação até agora seguida, falando-se nos escalões oficiais em abolir tão caros e majestosos empreendimentos. Não foram bruscamente extintos, mas condenados a uma lenta e triste agonia. (...)" (RAVAGNANI, $1978, p 。 73$ )。

A decadência da mineração não provocou somente a decadência gradual dos aldeamentos, ou de uma política indige- 
nista mais pacífica em relação aos índios, mas também a população regional, antes concentrada em inúmeros arraiais, se dispersou, e aos que permaneceram em território goiano não restou outra alternativa que a produção de subsistência que provocou uma profunda ruralização econômica e demográfica.

Juntamente com a decadência dos aldeamentos provocada pela desintegração da principal atividade econômica, verificava-se um processo de fuga dos índios dos aldeamentos que voltavam para junto dos que haviam permanecido arredios ao contato com os "civilizados", continuando a habitar os territórios tribais tradicionais, no norte da província de Goiás。 Ao que tudo indica, a depopulação dos aldeamentos se deu entre - final do século XVIII e início do XIX, continuando a se verificar em proporções menores no transcorrer de todo o século XIX, até que os aldeamentos fossem totalmente extintos.

A primeira informação que se tem sobre o retorno dos Xavante ao antigo território tribal é do viajante POHU, que em 1819 assim se referiu ao Carretão:

"(...) Atemorizados pelo tratamento grosseiro e imprudente e mau dos administradores dessa aldeia e convencidos, por repetidas provas, de que não se pensava em cumprir as promessas que lhes haviam sido feitas, voltaram à sua antiga vida nômade nas brenhas; apesar de já batizados, desde então não confiavam mais em nenhum branco, antes fugiam sempre que lhes era possível. Impetuosos, vingativos, dotados de memória muito fiel das ofen sas e humilhações... 
homens maltratados transformaram-se de compatrícios nosinimigos mais perigosos e figadais. ( ... )" (POHL, apud RA-

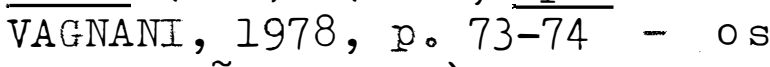
grifos são nossos)

Informa no mesmo relatório que a população Xavante do Carretão era de 227 índios, entre adultos e crianças (Idem, p. 74). Do líder dos indígenas que ainda permaneciam aldeados, ouviu o viajante POHL muitas reclamações indicativas dos maus tratos, da exploração do trabalho e da extorsão a que estavam submetidos os indígenas。

Cinco anos mais tarde - 1824 - CUNHA MATOS inclui, além das informações de POHL, o fato de ter existido uma grande epidemia na aldeia Carretão, e que os sobreviventes haviam fugido para os bosques. Informou em seu relatório que a população Xavante estava reduzida a 199 indivíduos, o que indica que muitos outros índios continuavam fugindo dos aldeamentos, indo reunir-se aos que permaneceram arredios (Apud MOREIRA NETO, 1971, p. 136)。

A redução populacional do aldeamento do Carretão era perceptível de ano a ano: em 1842 eram ainda mais de 100; em 1851 permaneciam na aldeia 70 índios entre Xavante e Xerente. Essa situação perdurou até 1855 quando foram transferidos para a margem direita do rio são Patrício.

A presença de Xavante também foi verificada em outros aldeamentos: em São José de Mossamedes há referência a estes índios, porém não se especifica a quantidade; em Salinas ou Boa Vista: em 1824 CUNHA MATOŚ a descreveu como decadente e habitada por 6 índios das tribos Xavante e Javaé; em 1844 Fran cis CASTELNAU encontrou 180 habitantes "quase todos Xavante cristianizados e de sangue puro"; na aldeia de Estiva, Couto 
de MAGALHÃES informou que sua população era de 200 índios, na sua maioria Xavante e Carajá, havendo 2 Canoeiro; na aldeia Tereza Cristina, mais tarde Piabanha, indicava-se a existência de 400 Xavante em 1851; em 1852 Frei Raphael de TAGGIA informava existirem 2139 Xavante e Xerente; no final do século havia algumas centenas de Xerente e os Xavante estavam extintos.

Pelo que ficou caracterizado acima, pode-se evidenciar: 1) que não foi todo o contingente populacional Xavante aldeado, mas somente uma parcela deles; 2) que grupos Xavante que não haviam sido aldeado's continuavam a ocupar o território tribal, compreendido entre os rios Tocantins e Araguaia; 3) os Xavante aldeados, ainda em finais do século XVIII, iniciam a saída ou fuga dos aldeamentos, voltando a habitar os antigos territórios tribais; 4) em virtude da experiência negativa qué tiveram do contato com a civilização, transmitida aos Xavante que permaneceram arredios, as hostilidades desses índios tenderam a se aprofundar.

É a partir desse quadro que se pode entender as relações desses indígenas com as frentes de expansão da sociedade nacional, representadas pela agricultura de subsistência e, principalmente, pelo gado. Quando essa frente de expansão passa a se avolumar, pelo estabelecimento da navegação e comércio ao longo dos rios Tocantins e Araguaia, e pelo incremento econômico devido à integração do norte goiano à economia extrativista amazônica, os conflittós com os silvícolas tornaram-se inevitáveis.

Para as frentes de colonização era imprescindível a expropriação das terras indígenas para a implantação dos núcleos coloniais necessários à atividade agro-pecuária ou ao 
apoio do comércio e navegação; para os índios significava mais uma invasão de seu habitat. Os conflitos, portanto, devem ter se generalizado em todo o norte da Província de Goiás, principalmente nos Vales dos rios Araguaia e Tocantins.

Em apoio aos colonizadores foi ordenada a "guerra ofensiva" contra as tribos indígenas Karajá, Apinayé, Zavante, Xerente e Canoeiro, através da Carta Régia de 05 de setembro de 1811 (Ver Apêndice 2)。 tinteressante observar que, de acordo com o mapa etnográfico brasileiro (NINUENDAJU, 1981), eram estes os grupos tribais mais numerosos e que tinham seus territórios tribais localizados entre os rios Araguaia e Tocantins. A repressão contra os indígenas não parou, porém, na ordenação da "guerra ofensiva", mas outras Cartas Régias e instruções autorizavam a organização de "bandeiras" que como já se disse se destinavam ao extermínio dos indígenas e abriam a possibilidade de ocupação econômica das terras por eles habitadas.

Caminhavam lado a lado os interesses econômicos e os instrumentos de dominação fornecidos pelo poder de Estado. De tal forma que:

"( ...) Estavam, pois, satisfeitas todas as exigências para que um novio '.. período de guerra ao índio se iniciasse e que os estereótipos de "ferozes", "belicosos", etc. TOltassem a circular, justificando dessa forma, mais uma vez, a agressividade e os ataques das frentes de expansão." (RAVAGNANI, 1978, p. 90)。

Assim, sempre a repressão e os aparatos legais encontravam a necessária justificação ideológica. Exemplo dis- 
to foi dado já em 1812 pelo Pe. SouZA que assim descreveu os Xavante:

"(...) Nação feroz e numerosa, residente na aldeia do Carretão, ainda que em grande número andam dispersos pelos bosques entre o rio Araguaya e o Tocantins; usam arco e flecha: são cruéis e roubadores." (SOUZA, apud RAVAGNANI, 1978, p. 91)。

Além da atividade repressiva, outra medida foi tomada pelo Príncipe Regente de Portugal, ainda em 1812: com a finalidade de garantir a navegação ao longo do Araguaia e ao mesmo tempo isolar os índios Xavante, Xerente e Carajá das frentes de expansão que iniciavam a ocupação nos vales desse rio, foi construído o presídio de Santa Maria do Araguaia. Um ano depois - 1813 - uma coligação dessas três tribos atacou e destruiu totalmente essa fortificação, que contava somente com doze praças que inicialmente resistiram, mas em seguida abandonaram-no (RAVAGNANI, 1978, p. 91 e 109 - nota 8).

Com todos esses conflitos e ações de hostilidades; os grupos Xavante foram se espalhando por todo o norte da Província de Goiás, em ambas as margens do Tocantins e até à margem direita do Araguaia, sendo sua presença relatada em vários documentos da época: em 1815 foram localizados por Francisco de Paula Ribeiro entre a barra do Manoel Alves Grande e Porto Real do Pontal. Em 1817 Manoel Aires de Casal encontrou-os também ali e mais tarde localizou outros grupos na margem direita do Tocantins, entre os rios Manoel Alves e sono. Em 1819 encontrou grupos Xavante por diversas vezes e espalhados em toda a região norte da província: encontrou um grupo no rio Maranhão; depois, com outros grupos nos rios Ma- 
noel Alves Pequeno e Piabanha; teve também notícias de conflito s com Xavante nos arraiais de Porto Real, Porto da Estrela e Carmo (Apud RAVAGNANI, 1978, p. 91, 92 e 93).

No relatório de POHL consta ainda o conhecimento

de vários ataques promovidos pelos Xavante contra povoados e fazendas, sendo que de um de seus relatos pode-se perfeitamente captar a ideologia que os habitantes da região tinham em. relação ao índio:

"(...) Com olhos invejosos, encaram êsses colonos as posses dos índios em geral, de cuja apropriação esperam grandes riquezas. Ouve-se constantemerte a queixa de que os índios ... possuem as melhores terras e devem ser exterminados e que o rei deveria enviar auxílio para a exterminação desses bichos (dão esse nome aos pobres índios). Que êstes eram uma praga paraa humanidade e que só com a aniquilação dos índios pode o rei felicitar e enriquecer os seus súditos. Ouve-se tais opiniões em todo o norte de Goiás, mesmo entre sacerdotes ilustrados." (POHL, apud RAVAGNANI, 1978, p. 92) .

Nas décadas seguintes (entre 1820 e 1845), uma frente de expansão pastoril, que ia pelo rio Tocantins em direção às fronteiras da Província do Maranhão, provocou uma série de conflitos com os Xavante e Xerente, principalmente na região do rio do Sono, Porto Imperial e Município de Natividade。 Essa frente de expansão colonizadora, baseada no gado se expandiu rapidamerte por todo o norte goiano sendo que seu desenvolvimento foi possibilitado pelas investidas que haviam 
sido realizadas no final do século XVIII e início do XIX, contra os vários grupos tribais da região, como os Timbira, Krahô, Xavante e Apinayé. Essa ocupação, entrëtanto, não se deu sem a resistência dos grupos indígenas. Aos conflitos, seguia-se a formação de bandeiras que objetivavam o extermínio dos índios "bárbaros" e "hostis"。A situação pode ser adequadamente captada pela passagem abaixo do relatório de JARDIM, de 1835:

"(...) Não assim os Xerente que têm agredido o Município de Pôrto Imperial: em fins de janeiro do ano passado acometeram a fazenda de Thomaz de Souza ... matando-lhe um sobrinho, destruíram gado e os móveis da casa; passaram depois a atacar a povoação de Pombal, mataram no seu sítio ao Juiz da Paz, a mulher, e três escravos, e conduziram cinco pessoas de sua família, porém os moradores se reuniram e foram em segmento, e alcançando-os fizeram prêsa de 19 pequenos indígenas, e 13 cristãos, que no alojamento deixaram os indios, que precipitadamente fugiram. (...) (JARDIM, apud MOREIRA NFTO, I971, D。190 e 191).

Após essa ação punitiva, os índios, em represália, promoveram alguns ataques à região. Foram organizadas novas expedições, com resultados negativos, até que a Câmara Municipal de Porto Imperial aprovou a liberação de uma verba para a organização de uma expedição mais poderosa para atacar os índios em suas aldeias。

Em 1838, outras medidas foxam tomadas contra os 
Índios Xavante e Xerente, passando-se também a dirigir esforços contra os Canoeiro. Além das bandeiras particulares, organizadas periodicamente contra os índios, consta no relatório do Presidente da Província, Pádua FIEURY, de 1838, a crganização de uma bandeira, financiada em $300 \$ 000$ réis, quantia essa deduzida da verba destinada a brindes para os povos tribais (Apud MOREIRA NETO, 1971, p.193-194)。O objetivo dessa bandeira era de adentrar até a foz do rio do Sono, para abater os Xavante, Xerente e Canoeiro que encontrasse pela frente。A bandeira fracassou, mas ela em si mesma sintetiza a política indigenista agressiva em relação aos indígenas (MOREIRA NETO, 1971, p. 192-194).

A situação de franca hostilidade para com as tribos indígenas do norte de Goiás era tamanha a ponto do presiderte FLEURY assim justificar o uso de fundos públicos destinados a medidas mais suaves de pacificação e aldeamento para a repressão:

"(...) Parece conveniente que
o govêrno, conquanto esteja
autorizado a engajar um mis-
sionário, a despender a quar
tia de $400 \$ 000$ réis com brin-
des, seja também autorizado a
despender alguma quantia com
bandeiras, porque de outra ma-
neira não se pode acudir o jus
to clamor dos Povos." (FIEUTY,
apud MOREIRA NETO, I97I, p.
I96).

Não bastasse a política francamente exterminadora adotada pelo governo e por particulares, outro dado é significativo: a utilização de grupos indígenas aliciados para guerrear contra os gmupos considerados "hostis". Essa situação envolveu, na mesma época, a ütilização dos Tapirapé e Carajá 
contra uma aldeia Xavante localizada abaixo de Salinas, que ".. se acreditava seja o grupo responsável pelos ataques aos julgados de Crixás e Amaro Leite。" (MOREIRA NETO, 1971, p。195\% Essa mesma situação pode ser observada pelo relatório do presidente SANTOS AZEVEDO que, em 1842, se refere ao uso dos índios Xavante aldeados no Carretão para tentar "a amizade do mesmo Chavante, que anualmente comete suas hostilidades"。

Ainda em 1844, Francis CASTELNAU, qualificando os Xavante de "ferozes", relata que pouco acima de Carolina, encontrou duas fazendas do coronel Ladislau em pleno território Xavante, tendo-lhe este narrado que contra esses índios havia organizado uma bandeira:

"(...) A frente de cento e
trinta homens o coronel ladis-
lau havia penetrado nos aldea-
mentos dos Xavantes, fazendo
cinquenta e um prisioneiros,
sem contar os que deixou mor-
tos no campo de luta. Quanto à
bandeira, teve ela apenas um
morto e dois ou três feridos e
ainda assim por imprudência."
(CASTELNAU, apud PAVAGNANI,
l978, p. 94-95).

Fica claro, pelas passagens anteriores, que a política indigenista que afetou os Xavante desde os aldeamentos até meados do século XIX em nada objetivavam a "integração" do índio à sociedade regional. A explicação não é difícil, pois qualquer que fosse a atividade econômica (agrícola, pastoril ou extrativa), não havia interesse em integrar o índio como força de trabalho, já que esta poderia ser suprida pela utilização dos braços que ficaram ociosos com a decadência da mineração ou nos aldeamentos já existentes e que ainda mantinham 
mão-de-obra indígena disponível。o maior interesse, tanto particular, quanto do Estado, era de exterminar as populações indígenas que impediam o avanço da economia, possibilitando assim a plena apropriação das terras。

A partir de 1845, verifica-se uma mudança na política indigenista na Província de Goiás, talvez por influencia do "Regulamento de 1845" (MOREIRA NETO, 1971, p. 200; RAVAGNANI, 1978, p. 95-9.6). Como foi referido anteriormente, em 1846, o presidente de Goiás, Ignácio Ramalho condena com veemência a utilização de bandeiras e a prática da violência con tra os grupos indígenas; propõe que em lugar da violência dever-se-ia buscar a civilização dos indígenas, através do estabelecimento de aldeamentos, nos lugares mesmo que constituem o habitat dos indígenas, e não transferí-los de seus territórios; considerava que assim se conseguiria uma mudança gradual nas relações com os índios, fazendo com que eles adguirissem hábitos e necessidades sociais que só poderiam ser supridos pela civilização (MOREIRA NETO, 1971, p. 200-204)。

Juntamente com as mudanças na política indigenista, tem início o deslocamento econômico da região do vale do rio Tocantins para o Araguaia. A ampla movimentação de colonos pelo rio Araguaia e os vários projetos de estabelecimentos pio neiros, oficiais ou particulares, afetaram os índios, tornando necessário o contato entre as frentes de atração e os grupos indígenas que habitavam a região (MOREIRA NETO, 1971, p。205206).

Foi, assim, no vale do Araguaia que Ignácio RAMAIHo inicia a dar as primeiras providências em relação aos grupos indígenas. Em 1846, ordena a fundação da Aldeia de Santa 
Maria do Araguaia, İra lá destacando uma Companhia de Pedestres (A Dud MOREIRA TETO, 1971, D.203)。

Junta= =fte com os esforços oficiais de implantação dos estabeleciz=zios militares e indígenas, foi ativada a ação dos missionárźcs capuchinhos, trazidos a Goiás para a catequização indíger = Tiesse período, a ação dos missionários se concentrava mais $r \equiv \equiv$ regiões pioneiras de colonização: na região do Tocantins, =o estremo norte da Província, e em toda a região do Araguaia. os trabalhos missionários do Tocantins eran dirigidos por Frei Erencisco de Monte Vito, que informava que a missão em Boa Vì̇ do Tocantins caminhava a contento, observando-se progresso zos 800 índios aldeados que "vão adquirindo amor ao estado soci̇z...". Na região do Araguaia, o trabalho missionário estava $\equiv c 0$ a responsabilidade de Frei Raphael de Taggia, então encařミミミdo da Aldeia de Santa Maria do Aragraia (RAMALHO, apud MOREZ: NETO, I971, p。206)。

Conste nesse mesmo relatório de RAMaLiHo (1848)

que em 1846 um grujc Javante aproximou-se voluntariamente em Salinas, sendo este Ėto assim narrado:

"( . o ) Nos últimos dias do ano passado (1846) apareceram alguns índios da Nação Chavante, no lugar denominado Salinas, pedindo paz, e a proteção do govêrno, seguramente por verem os Carajás protegidos e brindados e como se thes assegurasse que o govêrno almeja chamá-los à civilização, e tirá-Ios do estado errante em que se acham, foram resolvidos a voltar na próxima sêca, a fim de se estacelecerem no lugar que se thes indicar:" (RAMAIHO, agnd MOREIRA NErO, 1971, 


$$
\text { p. 206)。 }
$$

Sobre este mesmo grupo Xavante, consta que em 1848 o viajante Theotôrio SEGURADO encortrou-se com esses índios, quando viajava pelo Araguaia, tenảo feito comércio com eles quando faltou alimento à expedição (Apud MOREIRA NETo, 1971, p, 225-226)。

o governo de Pádua FLEURY, iniciado em 1848, embora teoricamerte defendesse as procostas de Ramaino quarto à política indigenista, na prática ia diretamente ao encontro dos interesses dos proprietários fundiários e criadores de gado da região, que soi o argumento de que essas terras eram essenciais à expansão da colonização, forçava o deslocamerto de grupos indígenas de suas ierras de ocupação imemorial. Assim, se tem notícia da transferência dos Krahô das margens do rio Farinha para o rio do Sono. Essa transferência foi defendida e realizada peio missionário Capuchinho Frei Raphael de Taggia, indicando que não era somente o Estado cue oem fazia o jogo dos interesses dominantes, mas que a ação desse miscionário é a expressão direta e sem disfarces desses mesmos interesses (Iderin, p。209)。

A transferência dos Krahô, porém, não tinha por objetivo somente a abertura das terras das margens do rio Farinha para a apropriação ireta, mas usar esses índios para que se promovesse a invasão das terras do rio do Sono, habitadas por índios Xavante "hostis"。

"( $\ldots)$ A seguir, são indicados - claramente os motivos porque

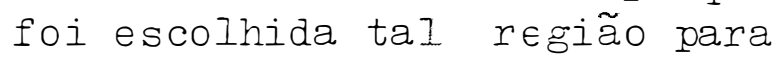
a localização dos Krahô, de Carolina: ao lado des vantagens de fertilidade, etc., fornecidas pelas terras em que 
se situa a nova aldeia, a presença constante de índìos Shavante e Sherente na região, levando sua hostilidade até as vizinhanças de Pôrto Nacional, impede sua prorta ocupegão。 muito provável que êsses índios Kranô, como no passado, tenham sido para aí trensferido corr o procósito de os forçar a uma resistência contra aquêles Erupos hostiso" (Apud MOREIRA NETO, 1971, p。209)。

A intenção de opor resistêrcias à hostilidade dos Xavante e Xerente, fica claramente demonstrada pela exposição de FIEURY para a instalação de um "Destacamento de Guardas Municipais". Esse fato não impediu, entretanto, que os Xavante matassem dois guardas que estavam estacionados na própria aldeia, conforme conste do relatório de 1848 (FIEURY, anud MOREIRA NETO, 1971, p。209-210)。

Na década de 1850, a ação indigenista na província de Goiás, continuou centrada no Araguaia, assumindo, porém, novas características: 1) a defesa da utilização da força de trabalho indígera, defendida pelo presidente Eduardo Olynpio MACHADO, ainda em 1850; 2) o reinício das pacificações de grupos hostis ao desenvclvimento, como a tentativa de pacificação de um srupo de índios Xavante na região do rio das Mortes relatada pelo presidente PEiREIRA DA CJNHA en 1856; 3) a continuidade da utilização da força armada como método para garantir a navegação, promover o desenvoivimento da colonização e forçar relações com os grupos indígenas, o que se deu notadamente com a implantação ao longo dos rios Araguaia, Tocantins e afiuertes, de presídios e colônias militares, com seus destacamentos militares; 4) a transformação dos aIdeamen- 
tos em porcações sertanejas, com a apropriação das terras indígenas com base nas leis então em vigor.

A política indigenista da década. de 1850 afetou e envolveu os Xavante de várias formas. Em primeiro Ingar, deve- se notar que as referências score os Xavante os situam exclusivamente na região do Araguaia, exceção aos pequenos contingentes que continuavam a habitar os artigos aldeamertos.

o avanço das frentes de colonização, assim como a adoção de medidas repressivas, fez com que, em meados da década, os Xavante transxusessem o rio Areguaia, indo ocurar o vaIe do rio das Mortes, conforme a exposição da tentativa frus-

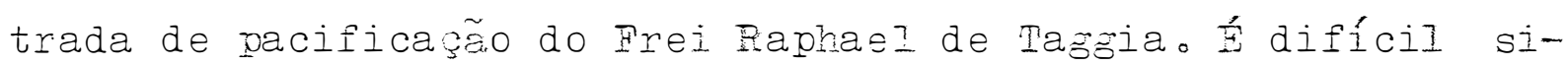
tuar com exatidão o ano em que foi inicieda a mudança de habitat, porém, é muito provável que tenina ocorrido após os incidentes de 1848, em que os Xavante atacaram o destacamento da Guarda Nacional nos aIdeamentos de rio do Sono, provocando a morte de dois soldados; temente da repressão usual que seguiam a esses ataques 'devem ter iniciado a mignaçãc, transpondo o rio Araguaia, sendo que em 1856 as referências já indicam que ocupavam o território compreendido entre o Araguaia e o rio das Mortes. Este assunto será tratado com maicr profundidade no ítem seguinte。

A transformação dos antigos aldeamentos em povoe ções sertarejas, acelerada peio próprio governo Imperial que determinou em 1855 a transferência dos índios que habitavam os aldeamentos do Carretão e São Joaquim do Jaminbú, afetou o redurido conting̃ente pöpulacionel. Xavante que os habitavam.

Motivados pelo processo de expropriação das suas terras, pelas transferêrcias forçadas de grupos indí ø̋nas, determinadas pelo avanço das frentes de ocupação naciora em 
toda a região do norte da província, no final da década de 1859 foram registrados inúmeros incidentes causados por índios hostis, havendo referências de conflitos envolvendo os Canoei ro, na vila do Pilar; os Xavante, nas proximidades do Arraial de Santa Rita; dos Kayapó, na Freguesia do Rio Bonito; dos Cenoeiro, na Comarca de Porto Nacional; dos Kayapó, no Distrito de Torres; dos Canoeiro, no município de Cavalcante, e muitos outros (Ver MOEEIRA NETO, 1971, p。226-229)。

Ao mesmo tempo (final da década de 1850) consta a presença dos Xavante vivendo pacificamente em várias regiões: em 1859 o viajante Vicente Pereira GONES encontrou uma aldeia destes Índios próxima de Porto Imperial, vivendo em caz e tendo habitações permanentes; informa ainda, a existência de três Índios das aldeias Krahô e Xavante próximas de Pedro Afonso (GONES, apud RAVAGNAMI, 1978, p。96)。 O relatório do presidente GAMA CERQUEIRA de 1859, traz informações de "numerosa horda de Chavantes que habitam... as populosas aideias que me consta existirem na margem esquerda do Araguaia, proximamerte à foz do rio do Peixe" lapud MOREIRA NETO, 1971, p. $226)$ 。

Imbora a década de 1860 tenha começado com mostras de grandes animosidade contra os índios e o apregoamento de punição, como o fez o presidente Araø̃̃o e NELIO (Apud MOREIRA IVETO, 1971, p.231-233), a violência e a repressão foram postas en prática de marieira mais sutil: através do expediente aparentemente simples e eficaz de transfcrmar colônias militares e indígenas em colônias penitenciárias. Issa aparente passividade, porém, como bem observa MOREIRA NETO (1971, p.232), encobria o caráter extremarente agressivo de taís medidas, que 
em seu intento anti-indígena podem ser comparadas à política repressiva de D. João VI.

Quanto às informações que se têm sobre os índios Xavante, consta no relatório do presidente ALENCASTEE, de 1862 , a situação desses índiós aldeados em Tereza Cristina, Pedro Afonso e São Joaquim do Jamimbu. As informações de Pedro Afonso e Tereza Cristina estão agrupadas no relatório, que diz estarem reunidos nesses aldeamertos Índios Xerente, Xavante, Krahô, Canela e Guajajara, sendo 2000 índios Xavante e Xerente e 800 Krahô. Na aldeia de São Joaquim do Jamimbú estão mais de 200 índios Xavante e Carajá, sendo que cada grupo tribal possui dois aldeamentcs (Apud MOREIRA NETO, 1971, p. $235-236)$ 。

Desse mesmo relatório de 1862 consta a existência de um considerável número de índios de "tribos bárbaras", dispostos na margem do Araguaia até sua foz, na seguinte ordem: Carajá, Tapirapé, Javaé, Kayapó, Canoeiro e Gradahu. Para fazer face a esses índios foram criados os presídios de Amaro Leite (Apud MOREIRA NETO, 1971, p. 236-237)。

Nenhuma outra informação existe sobre os indígenas, notadamerte quanto à presença de índios Xavante. ti interessante que se destaque que as únicas referências existentes sobre esse grupo tribal são tratadas quando se relata a situação dos antigos aldeamentos. Em toda a região do Araguaia estes não foram, em nenhum relatório da década, nem mesmo incluídos nos grupos indígenas hostis ou bárbaros que impediam ou dificultavam a colonização no vale do Araguaia.

A partir do último ano da década de 1860 e no decorrer de toda a década seguinte, a ação indigenista passa a 
ser caracterizada por um indigenismo de cunho "integracionista". Já o relatório do oresidente Ernesto Augusto Pereira, de junho de 1869, constitui-se nurra reafirmação das idéias usuais da ação indigenista como instrumento do desenvoluimento agrícola do Estado, através da qual se obteriam os braços necessários, de forma local e barata (PEREIRA, apud MOREIRA NETO, 1971, p.244). Deste mesmo relatório consta a presenca dos Xavante na Aldeia Tereza Cristina que continuava com uma população de mais de 3000 indígenas Xavante e Xererive; e em São José do Araguaia, composto somente por cerca de 50 indios Xavante. Como se sabe, já em 1872, estava em plena realização, o projeto indigerista implantado em Leopoldine por Couto de Magalhães, que, através do Colégio Izabel, previa a implantaçãc de um centro formal de educação de índłos com vistas a sia inte srậ̃o na sociedade nacional e utilização nos trabalhos de pacificaçãc e assistência a outros grupos indígenas. Paralelamente, iniciava-se uma xolítica de organização da colonização no vale do rio Araguaia, com a criação da Companhia de Navegação e Vaxor deste rio, com o emprego do indígena. Pelas informações contidas nos relatórios pode-se inferir que no decorrer da década de 70 as frentes de expansão tinham perdido o ímpeto inicial, serdo que agora se tratava de consolidar a ocupação, uma vez que as terras indígenas estaver expropriadas de seus primitivos donoso Era preciso, agora, tranquilidade para que se pudesse explorar as terras em plenitude, e um número crescente de trabalhadores. Essa situação é que justifica, portanto, a proposta de uma política indi genista que contivesse os indígenas, ao mesmo tempo em que se passava à execução de planos que viabilizassen a utilização da 
força de trabalho indigena nos projetos privados ou públicos de colonização。

Em 1880, o presidente da Província de Goiás, Aria tides de Souza Spínola, resume as informações sobre os vários presídios do Tocantins e do Araguaia, sendo que a situação dos mesmos refletia as tensões de âmbito mais geral sofridas pelas comunidades sertanejas das áreas pioneiras para com as comunidades indígenas ainda numerosas (SPINOLA, apud MOREIRA NETO, 1971, p. 259-264). o caráter agressivo das guarnições militares, dirigidas contra os índios de Goiás, muito embora as citações de advertências e punições contra os que agiam de forma não pacífica, foi objeto de comentários no relatório do Presidente Joaquim de Almeida Leite MORAES, em 1881, a ponto de rejeitar a continuidade de tais estabelecimentos (Apud Idem, p. 268-269). Pelas indicações dadas pelo governador SPINOLA, a prática de repressão contra os índios não era exclusividade dos estabelecimentos militares, mas era generalizada: "... 0 maior obstáculo para a catequese näo é o ódio dos indígenas... contra os cristãos, é o ódio destes contra aquêles." (Idem, p. 263)。

E, ainda, neste relatório que consta uma informação sobre os Xavante na região do Tocantins, indicanço que os mesmos estavam em estado hostil e que eram remanescentes do extinto aldeamento do Carretão:

"(...) Parece que em nenhum dêstes casos acham-se ainda os presídios da linha do Tocantins, quando perto dêles vagam Chavantes bravios e os Canoeiros, inimigos da população cristã, e está extinto o aldea- 


\subsection{Os Xavante em Mato Grosso}

Até a metade do século XIX, os sertões matogrossenses compreendidos nas regiñes do Xingu, das Mortes e Araguaia, eram ainda considerados como desconnecidos pelas autoridades dessa Província, conforme consta do relatório do presidente de Mato Grosso, Augusto LEVERGER:

"(...) Não há informações recentes ou precisas dos índios dos Distritos de Mato Grosso e Diamantino e 'não temos o menor conhecimento dos índios aue povoam os inexplorados sertôs, que mediam entre os rios Xingú, Arasuaia e das Mortes'." (Apud MOREIRA NETO, 1971, p. 146)。

O relato documental mais antigo da presença desses índios no Mato Grosso, na região que viria a ser seu habitat até a pacificação ocorrida em meados do século XX, consta do relatório do presidente da Província de Gciás, Pereira da Cunha, de 1856, no qual noticia a expedição sob a direção de Frei Segismundo de Taggia, que procurou estabelecer contato com um grupo Xavante hostil, na resizão do rio das Mortes (Apud MOREIRA NETO, 1971, p. 216-219; idem, RAVAGNANI, 1978, D。128$-130)$ 。

Antes desse, existe um relato de Joaquim da Costa Siqueira que descreve uma bandeira organizada pelo governador matogrossense para aprisionar um grande quilombo que, segundo informações de um escravo preso na cadeia de Cuiabá e de um indio Xavante, existia, no sertão do norte. A bandeira que consta ser de 1800, era comandada por José Iuiz Monteiro e tinha como guias os dois informantes. De acordo com o relato re- 
tornou em três de junho de 1800, mas:

"... não achou o quilombo dos
pretos por terem sido todos
assassinados pelo sentio cha-
vante, a quem conquistiou, con-
duzindo-os, e também vários
Pacairys, que S.Fur fez repar-
tir pelo povo, e como estra-
nharam o alimento, morreram
quasi todos". (SIQUEIRA, apud
RAVAGNANI, 1978, p. II7-lI8).

É, sem dúvida alguma, correta a afirmação de que os Xavante imigraram de Goiás com destino ao Mato Grosso. Mas a falta de dados documentais complica em muito a questão. De acordo com Maybury-Lewis, a imi gração teria se dado na década de 1840 (RAVAGNANI, 1978, p, 118)。Para GIACCARIA e HEIDE (1972, ‥ 23), a travessia do rio Araguaia peIos Xavante ocorreu por volta de 1860-1870, mas assinala que antes dessa grande travessia um outro gruoo a havia realizado, porém, que deles não se teve notícias. Para Darcy RIBEIRO (1977, p. 65), os Xavante começaram a deslocar-se para a marzem esquerda do Tocantins em 1824, depois para o Araguaia em 1859, indo depois se estabelecer nos campos do rio das Mortes, nãn precisanco quando isto ocorreu。 Outra hipótese é de RAVAGNANI (1978, p. 107 e 118) para quem os Kavante atinziram a rezião do rio das Mortes e Serra do Roncadon em 1820, reconhecendo também que, por volta de 1800, já existiam condjcões para que um gruxo emigrasso para o rio das Mortes, sendo este um caso isolado de um zrupo que para lá se dirigiu, antecipando um processo que se desencadearia mais tarde。

Tendo em vista que o relato da tentativa de cacificação dos Xavante por Frei Segismundo de Tag̊ia, de 1854 , pode ser considerado como um dado documental significativo, 
as hipóteses de GIACCARIA e HEIDE de que tenha ocorrido entre 1860-1870 e a de RIBEIRO que ocorreu depois de 185.4, ficam automaticamente carentes de comprovação.

Considera-se que seja plausível o reconhecimento de GIACCARIA e FEIDE e de RAVAGNANI de que, antes do processo de mi.gração massiva desse grupo tribal, tenha ocorrido a imigração de um ou mais grupos de Goiź:e para Mato Grosso. Esta probabilidade se funda nas próprias características econômicas, sociais e políticas do grupo. Em primeiro lugar, a economia Xavante era fundamentalmente de uma sociedade caçadora e coletora, embora deservivessem uma arricultura rudimentar. Este traço exigia uma constante mobilidade espacial do grupo tribal, fazendo-os aumentar constantemente o território tribal. Essa mobilidade espacial se caracterizava, e ainda continua a ser um traço marcante no grupo, por dois processoe de migração: o primeiro se realiza habitualmente duas vezes por ano para as caçadas. Uma se faz logo que começam a escassear os produtos das plantações, por volta de julho. Retornam no final de setembro para a prevaração do terreno e da semeadura. No início de dezembro empreendem outra migração, retornando na época em que o milho possa ser usado. O segundo é caracterizado pela ocorrência do iracicnamento de uma antiga aldeia que atingiu seu ponto de estrangulamento - cerca de 150 a 250 pessoas - fazendo com que uma parcela da população, motivada por laços de carentesco e ou de amizade, inicie a construção de uma nova aldeia。 Finalmente, os Xavante não chegaram a desenvolver uma organização política ampla que desse unidade ao grupo tribal; cada aldeia constituía-se numa formação social autônoma e independente em relação às demais. Os laços que as uniam se limitavam ao parentesco, quando havia, e a uma iden- 
tidade cultural (reconhecimento dos traços culturais característicos do grupo: Iíngua, corte de cabelo, pintura corporal, ornamentos e trançados, etco), o que não impedia as suerras endógenas ao grupo tribal pela invasão do território de dada aIdeia por outra, pela suposição de terem provocado a morte de membros da aldeia pela prática do feitiço, etco

Por estas características, é possível que tenham ocorrido migrações de um ou mais grupos (neste caso a população de uma dada aldeia), motivados ou pela expansão das frentes de colonização da sociedade nacional, ou por pressão de inimigos tribais。

Em sendo esta interpretação verdadeira, a hicipótese de RAVAGNANI não está de todo incorreta. A ela deve-se fazer a ressaiva de que assim como antes de 1820 havia occrrido imigraçãc de um gmupo para o território matogrossense, também esta data marca simplesmerte a continuidade de migrações isoladas.

Reconhecendo essas migrações isoladas, aliás ressaltadas pela tradição oral do grupo, como se verá em seguida, crê-se que as imigrações massivas dos Xavante tenham ocorrido a partir de meados do século KIX, entre 1848 e 1854。Três evidências documentais corroboram esta alternativa。

1. o ataque promovido pelos Xavante ao destacamento da Guarda Nacional nos aldeamentos do rio do sono, provocando a morte de dois soldados, constante do relatório do presiderte da Província de Goiás, Pádua FIEURY, de 1848 (Apud MOREIRA NETO, 1971, p. 209-210);

2. a tentativa de pacificação do Frei Segismundo de Taggia, em 1854, dirigida à procura de um grupo Xavante hostil da região do rio das Mortes, constante do relatório do 
presidente da Província de Goiás, Pereira da Cunha, de 1856 (ADUd MOREIRA NETO, 1971, p。216-219).

3. embora conster al gumas informações de conflitcs envivendo os Tavarite na região do Araguaja até o finei da década de 1850 (Ver MOREIRA NETO, 1971, p。226-229), a partir de 1860 não consta de nenhum outro relatórío a presença de hostilidade promovida por estes índios na banda goiane do vale do Araguaia, ou informações sobre a preserça de grupos arredios, a não ser quando são relatadas as populaçoes dos antigos aldeamentos (Idem, p. 23I-276).

o primeiro documento dá conta de uma circunstûncia grave envolvendo os Xavante, que despertou nestes o temor de represálias, que era a prática inciagenista usual nesties casos e que os Xavente já tinhari sido pacientes desde há lono tempo, provocando o infoic de uma fuga masaiva. O segundo docla mento constata a preserça Xavante em terras matogrossenses, provavelmente em número significativo, a ponto de justificar um smpreendimento como a exredição organizada。 O terceiro dado documental demonstra que, durante a década dë 1850, grupos de Índios Xavante hostis continuavam ainea habitando o vale do Aregraia, mas que devem ter migrado até o final da década, ou foram exterminados pelas frentes de colonizaça nacional, posto que niss se constituían num empecipho para a excansão da coIonização a partir de 1860 .

Para a fase de deslocamento, posse do território tribal e primeiros tempos vividos na região compreendida entre os vales dos rios Cristalino e das Mortes, as fontes de informação disponíveis são a tradição oral tribal e seus mitos, len das e contos, amplamente documentados por GIACCARIA e HEIDE 
(1972, 1975a e 1975b), tendo como principal informante "Jerônimo", o mais idoso Xavante, sendo ele TAMARI TEDEFA (sonhador, pacificador) (36). Transcrever-se-ão abaixo os trechos mais significativo serdo que o primeiro se refexe è ocuog̣ão do Arasuaia, de sua travessia e início da ocupação do rio cristalino:

"Junto ao rio Araguaia (OPRì) fundarar a aldeia de DUNARI (casas cobertas com capim); mas os brancos voltaram a incomodar e assim atravessaram o rio e fundaram uma nova aldeia, de cujo nome não se lemoram. Mas nem esta nove. posição apresentava sesurarga. Por isso passaram o rio CristaIino, fundardo a aldeia de MARATO' BRE, so a a guí de MSE' RERUMUVA, DUETOODI e PARATSi, a. quem estava confiado 0 comando da empresa.(...)" (GIACCARIA e HEIDE, I972, p. 22)。

De acordo com o mito DZOMORÍ (GIACCARIA e FEIDE, 1975b, p. 20-46), -em "Narãtólore" durante uma caçada da estação da seca, uma parte da aldeia foi cagar junto com os três chefes, estes procuraram convencê-los a voltar para Goiás, pois "favoreciam muito os civilizados". Isso irritou muito a comanidade, que procurou eliminá-los, enquanto eram entretidos a

(36) O material de GIACCARIA e HEIDE foi publicado em I972, e depois, em dois outros volumes em 1975. Ainda em 1983 tive a oportunidade de rever o velho Xavante Jerônimo em Couto de Magalnães, pois este havia saído no ano anterior da Missão Salesiana de Sangradouro, indo colaborar na construção de ume nova aldeia na área do P.I. Culuene, xara garantir a posse do território tribal da R.I. de Parabubu contra as ameaças de fazendeiros. 
ccmer mel. Dois foram mortos (TSE'RERUNierie e PARATSé), salvando-se somente DUProoñ, graças ao auxílio de sua irmã. A caçada continuou, mas os dois irmãos permeneceram vigiados até o fim da caçada. Um dia, porém, por ume distraça dos sentinelas os irmãos conseguiram fugir e foram contar rara os brancos o que Ihes havis acontecido. A reação veio em seğuida;

"Os brancos então se armaram e, durante a noite, junto com os índios Xavintes seus amigos, circundaram o acampamento de caça e mataram todos os homers menos TSEREDZA-DADZU THRE e PARIUPTSi, que consegui ram fugir.

Os Xavantes vencedores Ievaram as mulheres e as crianģas rara a aldeia, enquanto os brancos voltaram para pedir reforcos, a fim de exterminar todos os Xavantes, inciusire os que tinhari sido seus aliados. Mas os Xavantes penceberam a traição e mandaram um com um cabrito que servisse pa ra atrair a atenção dos brancos, a fim de descobrinem onde se reuniam. Descoberto o Iu gar, alguns índios que conheciam o português se testiram como cirilizados para penetrer no acampamento dos brancoso Os Xavartes descobriram o que já suspeitavam: os brancos tinham a intenção de matá-Ios. Aproveitendo, pois, da noite e de uma chuva improvisa, que certamente contivera os brancos nos acampamentos e apagara suas fogueiras, fugiram daqueia aIm deia e atingiram o rio das Mortes. o único grupo aue então atravessou o rio, ̀̀ aItura 
do atual São Domingos (WEDEDZE), foi o de BUTSE; os outros ficaram ao longo do rio, apavorados, por causa de grandes cetáceos chamedos PEDZAYU (boto, Sotalia Brasiliensis)," (GIACCAEIA E HEIDE, I972, p. 22 e 23).

A passagem do grupo de BuTse e sobre os que ficaram com medo do boto é relatada no mito WADZWI'WA (Ideri, $19750, p, 147-158)$.

Na região do rio das Mortes construíram a primeira aldeia denominada WHE'U. Mas, por causa de uma epidemia, passaram para DZUB'ADZE ou TSOREPRE, onde permaneceram por volta de 30 anos, a partir daí sucessivamente, o grupo foi se dividindo e fundanco ncvas aldsias, primeiro mmo noroeste, depois sucioeste e oeste, depois eul e, novamente, norte (Ter GIACCARIA e HEIDE, 1972, o. 23-s. e 35). Fmbova a tradição ora e a mitologia do grupo não tenham necessariamenta uma cronologia lógica, contêm a confirmação das linhas gerais destacadas anteriormente: I) coincidem quanto ao local por onde deixaram Goiás e atingiram as terras de Mato Grosso: oróximo ao sul da Ilha do Bananal, na resião denominada de são Domingos; 2) o motivo da Iuga era de estarem escapando das frentes de colonização que os pesseguiam e atacavam; 3) a ocupaçá do rio das Mortes pelo grupo de BUTSE si£nificou, provavelmente, a formação de um grande aldeamento, com vistas a garantir a posse do território tribal tomado de vários grupos tribais, com os quais tiveram que travar várias guerras, e para prevenir novas incursões dos brancos; 4) o fato de um grupo não ter feito a travessia do rio Araguaia, permanecendo em território goiano, continuando as hostilidades ao longo de toda a década de 1850; 5) 
a passagem de um grupo Xavante que havia atravessado o rio Araguaia anteriormerte.

Outro aspecto a considerar, é que a ocuvação Xavante da região compreerdida entre os rios Araguaia e das Mortes era habitat de outros grupos tribais, com os quais tiveram que entrar em guerra a fim de delimitarem novas fronteiras espaciais e se apossarem das terras.

Tomando como ponto de referêricia a resião compreendida pelos vales dos rios Cristaino e das Mortes, como sendo o habitat Xavante quando em terras matogrossenses, conforme evidenciam vários autores (37), é possível a localização dos principais grupos que a habitavam: ao sul, tendo o rio das Mortes como limite, habitavam os Bororo; ac leste estava o rio Araguaia, ertão habitadc pelos Canoeiro; a nordeste situava-se a Ilha do Bananal, região habitada pelos Carajá; ac rrorte estava o rio Tapirapé, habitado por índios homônimos; ao oeste e noroeste estava a serra do Roncador, além da qual os índios xingranos, notadamente os Suyá e Trumái; a sudoeste, entre os rios das Mortes e o Culuene, os Kayapó (meridionais) - (NIMUEIDAJU, 1981, mapa anexo)。

Da tradição oral Xavante ccnstam muitos conflitos com outros índios, porém é muito difícil identificá-los já que a. nominação é genérica, referindo-se aos demais como "índios que falam quase igual aos Xavante", "tribo que vivia perto do Marã Watsèdè", "Índio de olho brilhante"... A única exceção é para com os Bororo que são identificados.

(37) BAIDUS (1948，p。157); GIACCARIA e HEIDE (1972，p。36); RIBEIRO (1977, p。65); RAVAGNANI (1978, p。119); NIMUENDAJU (1981, p. 45 e mapa anexo). 
Da literatura disponível constam conflitos, moti vados pela ocupação da terra, entre Xavante e os Bororo. (AIBISETTI e VENTURELII, 1962, p。292-293; ALBISETTI e COLBACCHINI, 1942, D. 20-2I, 150 e 206-2II); entre os Xavante e os Carajá (BALDUS, 1970, p. 68) e entre os Xavante e os Trumái (VILIAAs BOAS, 1975, p。26-30)。

Em relação aos Xavarte e os Bororo, consta que a região compreendida entre a margem esquerda dc rio das Mortes e na mesopotânia entre este rio e o Culuene era território dos Bororo, pois a toponímia dos aifluentes dessas margem

"... levam, indiscutivelmente, nomes da língua dos orarimosodósue e provam que os borôros passavam alsum tempo por aquelas paragens." (AIBISETTI e COLBACCEINI, 1942, p. 20-21).

BALDUS (1937, p。II3 e 320) endossa esta interpretação ao colocar que os Bororo tiveram seu território reduzido pelo lado leste, oeste e sul pelas investidas das frentes de expansão e ao norte tiveram que fugir "a índios ainda desconhecidos, aos quaes os Bororo dão o nome de Kaiamo..." , a ponto de se refugiarem junto às missões salesianas, mas mesmo a ́ os Bororo se viram a reaçados, pais os Xavante chegavam até a Missão Salesiana de Meruri a ponto de se pensar em abardoná-la. Do mesmo modo, muitas fazendas dos arredores foram evacuadas pelos proprietários e a estrada entre Cuiabá e Goiás era bastante insegura. De acordo com AIBISETTI e VENTURELII (1962, p. 701 e 702), Kayamo é uma designação genérica para qualquer tribo inimiga, no entanto os Bororo identificam como inimigos os Xavante "por terem sido êstes índios os últimos. com os quais lutaram até aos nossos dias ..."

"(...) Entre as duas tribos há 
ódio inextinguível. Em tempos remotíssimos se guerreavam e até hoje os bororios temem os seus ataques. Por vezes numerosas turmas atravessam o Rio das Mortes, invader o territórios dos Orarimogodósue, matando e destruindo tudo o que se lhes antolha na passagem." (ALBISETTI e COLBACCHINI, 1942, p. 250).

Situação semelharte é verificada em relação aos Carajá, que habitavam a margern direita do médio Araguaia. BAIDus (1945, p. 68), diz que esses índios gostavam de ficar perto das casas dos brarcos por medo dos Xavante. RAVAGNANI (1978, p. I23) compiementa essas informações, baseando-se em Tíbor SERELJ, que assegura que na época da desova da tartaruga, entre a:o ato e setembro, alguns Xavante atravessam o rio dasMortes e chegam até as praias do Araguaia para coletar ovos causando grande medo aos brancos e Carajá que habitam a margem direita desse rio. Complementa, ainda, com a informação de Willy AUREII para o qual os Carajá são as vítimas prediletas dos Xavante e olham nostálgicos as terras de onde foram expulsos após sanguinárias excursões Xavante; ademais, que para os Carajá os Kavante são os responsáveis por todos os desaparecimertos e mortes ocorridas entre os civilizados e mesmo não o sendo, estes os responsabilizam.

A última referência explícita de conflito dos Xavante e outro grupo indígena é em relação aos Trumái, que segundo os irmãos VILIAS BOAS (1975, p. 26-30) foram expulsos de um afluente da margem esquerda do rio Culuene a mais ou menos 150 anos pelos Xavante, a quem chamam de "Assumadí"。Justificam essa interpretação baseando-se em duas narrativas dos Tru- 
mái: numa, estes índios contam que seus antepassados residiam ao ncrte do ponto onde hoje se encontram, nas marsens de um imenso laฐo, ao qual dão o nome de "Pararrú". Ai soireram vioIentos ataques de outra tribo de nome "Assumadi", que invadiu as suas terras, e, por isso, resolveram mudar-se, guiados por dois grandes chefes. Chegaram às margens do rio Culuene, onde dividirarm-se em dois grugos - um voltou às antigas aldeias, o outro prosseguiu viagem, subindo por esse rio, ao longo da margem direita, onde Ioram levantando inúmeras aldeias. A outra narrativa, considerada verdadeira pelos autores, é que os Truméi procederam não do baixo-X̄inğ, mas das cabeceiras de um afluente da margem esquerda do Culuene, concluindo que:

"Não é impossível, também, terem sido os Kavante os índios que expul saram os Truméi dos seus antisgos domínios a leste do Alto-Ringu. Assumadi, nome que os Trumái aplicam aos seus a gressores passados, tèm alguma semelhança fonética com a fala Kavarte. Cabe lembrar também, que esses indios devem ter atingido a resião do rio das Mortes e serra do Roncador há século e meio mais ou menos, época provável da imigração Trumái." (VIIIAS $\mathrm{BOAS}, 1975, \mathrm{p} \cdot 30$ )。

Os argumentos dos autores que tratam ou supõem conflitos entre os Xavante e outros grupos tribais não são convincentes, porém, dadas es condiç̃es históricas de tomada do território são muito prováveis esses conflitos, daí terem sido enumerados.

Com reiação aos seus vizinhos setentrionais, os Tapirapé, não consta ter havido confronto entre eles e os Ka- 
vante, embora o território tribal Tapirapé constitússe limite a este "... não haver notícia dos Xavante terem che gado até zá." (BALDU, 1970, p.49)。. De acordo com BALDUS (Idem, p.59), os Tapirapé não consideravan os Kavante como amigos, mas nada conseguiram dizer sobre estes indios, por eles denominedos "Kyrydjá", nem mesmo reconhecer colunas de fumaça produzidas pelos Xsvante:

"Dizian os Tapirapé não
serem os Ampaneá amiöos dos Eyrydjá, seus vizinhos orientais, chamados "Xavantes" pelos brasileiros. (...)

Mas os Tapirapé runca puderam mostran-me colunas de fureça produzidas pelos Kyrydjá, cujo ternitório na hinterlendia da margem direita do Tapirapé localizassem precisamente ao sudeste de Tampititam na. Não sabiam dizer nade acêrca deles, nem se Iembravam de algum encontro com eles.(..)" (BALDUS, 1970, p. 59). ,

A Ĺnica notícia em aue constam contatos entre os Xavante o os Tapirapé, no período, foi no Colégio Izabel, conforme o relatório de Cícero de ASSIS de 1875 (Apud MOREIRA NETO, 1971, p. 251-252)。 Porém, desse mesmo documento pode-se inferir que a situaçeo de contato era provocada e motivada pelos interesses da ação indigenista do Estado sobre os grupos indígenes do Areguaia, tendo como "recrutador" os "Kayapós"。

Fm vista do território Kayapó estar situado ao sul do local de imigração Xavante no Aragraia e também sudoeste na época de efetivação da ocupação do habitat mato grossense (NINUENDAJU, 1981, mapa anexo), deve ter havido muitos confrontos envolvendo os Xavante e os Kayapó, embora a única indica- 
ção dos mesmos seja dada pelo mesmo ASSIS, em 1875, quando se refere à prática de "aquisição de menores" para o Colégio Izabel (MOREIRA NETO; 1971, p. 25I).

Retomando o processo de ocupação da área situada no rio das Mortes, já foi citado que a primeira aldeia construída pelo grupo chefiado por "Butsè" se chamou "Wede'u" e que devido a ura epidemia que exterminou quase todos os velhos, abandonaram-na fundando "Burõtõró", ou também chamada pelos nomes de "Dzub'adze" ou "Tsõreprè". Presume-se que nesse local tenham passado cerca de trinta anos, rosto que a tradição oral = se refere à celebração da "xerfuração das orelhas" (38) de seis grupos de idade nesse local: HOTO RA (peixinho), ABAREU (piqui), NODZOU (milho), ANAROWA (esterco), TSADA'RO (sol) e AY'RERE (pequena palmeira). Consta que, até então, estavam todos unidos, formando uma única aldeia, mas a morte de um índio causou a separação do grupo de RAPA, que foi fundar nova al-

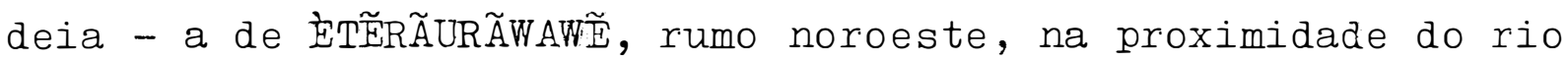
Culuene, onde foram perfuradas as orelhas de outros dois grupos de idade: dos HOTORÃ (peixinho) e dos TIROWA (carrapato). A este aldeamento, postericrmente, juntou-se o grupo de TSIA; mas por questão de lutas entre as duas aldeias, motivadas por questão de brigas de facções, justificadas por "feitiços", um grupo da aldeia de "Burõtõró" foi furdar outro aldeamento chamado "Wabdzèrèwaprè", em direção sudeste, no divisor de

(38) O DANÕNo, ou festa da perfuração das orelhas, é um rito de passagem Xavante que marca a transformação dos jovens (Waptè) em adultos guerceiros (Ritey'wa). Esta festa é realizada de acordo com os grupos de idade, ou conjunto de indivíduos que nasceram no mesmo lapso de tempo, aproxima damente 5 a 6 anos, entre una festa de Danõno e outra. 
águas dos rios Culuene e Areões, onde permaneceu dois ános, indo sucessivamente para as margens do Culuene, na direção oeste, e depois em direção norte, seguindo o curso do culuene. Nesta migração fundaram duas aldeias, chamadas "Wedetede" e a cutra "Oniudu" (GIACCARIA e HEIDE, 1972, p. 23-24)。

Com isto teve início uma série de constantes separações e uniões, apresentando uma permanente mobilidade horizontal do grupo tribal, tendo como motivos epidemias, feitiços, mortes, brigas entre grupos locais, enfim, rivalidades das próprias fações que se uniam temporiamente a outra (RAVAGNANI, 1978, p. 126-127). De qualquer forma, esse processo de migrações sucessivas, divisões, fundação de novos aldeamentos possibilitou aos Xavante o controle de uma imensa área situada no quadrante formado entre $048^{\circ}$ e o $51^{\circ}$ meridiano e $12^{\circ}$ e $016^{\circ}$ paralelo (GIACCARIA e HEIDE, 1972 , p. 34 - mapa). Nessa vasta área, os Xavante ocuparam ${ }^{(39)}$ : o das Mortes, na região de São Domingos; a região do rio Culuene e rio Sete de Setembro; toda a região compreendida pelo vale entre os rios das Mortes e Culuene e denominada lagoa; a região dos formadores do rio Ronuro, nos locais denominados "batovi" e "paraíso"; a região do rio Suiá-Missu, seguindo a Serra do Roncador, loca-

(39) Este processo migratório levantado por GIACCARIA e HEIDE (1972, p. 23-29), está minuciosamente posto em mapa (Idem, p. 35), sendo possível recuperar adequadamente não só o habitat Xavante, como a localização dos diversos aldeamentos construídos, alguns dos quais os índios foram violentamente expulsos e chacinados, quando do avanço econômico na primeira metade do século XX. O processo descrito por esses autores coincide com o nosso levantamento de campo realizado entre 1977 a 1979. É lamentável, somente, que os dados disponíveis limitam-se à dispersão geográfica do grupo, às aldeias construídas e aos motivos internos que causaram as divisões. 
lizando-se nos braços da margem direita deste rio; finalmente, transpondo o rio das Mortes, um grupo se localizou c na região de "São Marcos" e outro na de "Sangradouro"。

De qualquer forma, nos limites do período ora tratado, o novo habitat Xavante protegia-os das frentes de expansão goianas e matogrossenses e que, nessa época, arrasavam com as populações nativas com que se defrontavam. Mas o rio Araguaia constituía o.limite dos colonizadores, além do qual era "sertão desconhecido", porém bastante cobiçado por suas riquezas.

A longo prazo, porém, o habitat era muito vulnerável, como bem demonstra Ravagnani:

"(...) Os rios Araguaia e Mortes eram navegáveis em toda sua extensão e um convite para futuras penetrações. O primeiro constituía, desde há muito, uma séria tentação para se comunicar com a Província do Pará. As tribos que habitavam sua margem direita, os Kayapó e Tapirapé principalmente, já estavam submetidas. Faltava, entretanto, um maior desenvolvimento do capitalismo ainda em ascensão para que fosse economicamente explorado em sua plenitude.

A parte meridional não apresentava nenhum obstáculo natural a qualquer tentativa de ocupação. Seus habitantes, os índios Borôro, há longo tempo estavam dominados, decadentes, divididos, reduzidos em sua população e servindo a seus cclonizadores na redução 
de novos grupos. No limite ocidental havia total segurança. A Serra do Roncador seguida pela região do alte Xingu permanecia impenetrável, principalmente pelas várias cachoeiras existentes, tornando- o inaproveitável para a navegação, além de indígenas totalmente desconhecidos。o norte do território estava guarnecido pelas serras Tapirapé, do Matão e Gradaus, que ocupavam imensa extensão de terras inóspitas. Apenas os flancos. oriental e meridional eram bas- tante suscetíveis a invasões. E eram justamente os que estavam voltados para as frentes pioneiras, embora guardassem relativa distância. Esta era, realmente, a segurança com que os Xavânte contavam." (RAVAGNANI , 1978, p. 125-126).

Como bem destacou Ravagnani, os flancos oriental e meridional eram suscetíveis de invasões: o primciro, representado pelos rios Araguaia e das Mortes, não só navegaveis em toda a sua extensão, mas que penetravam no centro do território Xavante; o segundo, era representado pela área ocupada pelos Bororo, a anos em contato com o branco, pela qual cruzavam as rotas terrestres utilizadas nas relações entre as Províncias de Goiás e Mato Grosso.

Na verdade, pouco foi o tempo ell que puderam viver tranquilamente no novo território, pois foi pelas duas regiões apontadas como vulneráveis que começaria a invasão do território. tribal Xavante em Mato Grosso. Agora com uma agravante: estavam cercados, não podendo dispor de novas imigrações e de fugirem de um contato que seria inevitável, tão logo a sociedade nacional volta 
a se expandir com todo o ímpeto no centro-oeste.

Em 1854, o presidente da Província de Goiás ordenou a formação de uma expedição civilizadora, sob o comando de Frei Segismundo de Taggia, encarregado do aldeamento do Jamimbu, à procura dos Xavante hostis da região do rio das Mortes, "que têm aí numerosas aldeias" (BAIDUS, 1970, p. 59). A expedição foi composta, além do Frei Taggia, por dez praças de linha, por seis índios Xavante da aldeia do Capitão Felipe Xavante e também por civịs.

Depois de muitas interrupções para o preparo do equipamento e engajamento dos elementos, a expedição partiu do porto de Piedade. Desceu o Araguaia até a foz do rio das Mortes, subindo-o durante dez dias - percorrendo-o por umas cinquenta léguas, até chegar ao caminho que conduzia à aldeia dos Xavante "bravos"。Nesse local parou para limpar as armas e mantimentos que tinham se molhado devido a quatro dias de chuvas torrenciais. A seqülencia dos acontecimentos será deixada por conta da transcrição literal do relatório de PEREIRA DA CUNHA, de 1856, que bem caracteriza o tipo de política indigenista ado tada:

"... não avistando fumaças da parte da Aldeia, mandou o capitão Pedro Chavante com algumas praças, e índios examinar se os Chavantes bravos estavam na Aldeia, e recomendou-lhe que, encontrando-os não consentisse bolir com êles, e no caso, contrário rastejar-se-ão até alcançá-los, e voltasse a dar- Ihe parte de tudo. Esta comitiva partiu no dia 17 e ̀̀ 19 reconhecendo que estava perto dêles, o capitão, subindo a uma árvore, descobriu a rancha 
ria, e em vez de voltar, como Ihe fôra recomendado, escondeu - se no ćaminho por onde iam buscar água e lenha, e apenas acoitou-se com alguns de seus companheiros de viagem, viu passar quatro índias, detendo-as e reconhececendo que eram Chavantes, elas the disseram que na Aldeia só existia um velho por terem os moços saído à caça de queixadas, porém que era melhor voltar, porque sua gente estava com vontade de brigar, e não queria paz, mas que poderia sempre conversar com o velho. Chegados à Aldeia, - velho não queria falar, sim lançar frexas, contudo sempre conseguiram conversar com ele, pondo-o em cêrco: o capitão fez-lhe vêr que era seu parente que tinha ido com o missionário para levar-lhes mimos, e não para brigar, e que desejava a paz; 0 velho respondeu que os cristãos são muito maus, que quando êles estiveram no Carretão sofreram judiações, com palmatória, tronco, corrente, chicote e colar, que não obstante isso esperasse pelos outros com quem podia conversar, porém, as mulheres aconselharam ao capitão, e companheiros que retirassem porque êles eram poucos, e não podiam com sua gente。A vista disso o capitão disse aos seus - retiremo-nos que êles não estão de bôa tenção, mas antes de saírem, contra as recomendações do missionário, carregaram xicununs, esteiras, frexas, etc., e tendo caminhado duas léguas 
e meia, mostrando-se alguns da comitiva cansados, disse o capitão - pois bem pousemos aqui, porém é preciso que o cabo faça ter sentinelas, porque os índios bravos vem hoje atacar-nos - e não tomando o cabo as providências precisas, ao deitar-se foi morto a cacête, assim como um soldado. Aos gritos de um paisano, que teve tempo de levantar-se com arma, acudiram os índios mansos e com tiros fizeram fugir os bravos, que seguiram atraz dalgumas praças que corriam sem armas. Segundo informou o missionário foram mortos quatro, ou cinco dos índios bravos, e o que matou o cabo apoderou-se da arma do mesmo, disparando-e feriu alguns índios mansos. Passado o conflito, achou o soldado Peregrino dos Anjos com duas feridas na testa, desacordado, e com a arma na mão, e carregando-o continuou a comitiva em seu regresso, " e no dia 20 pelas 10 horas da noite achava-se o missionário, que logo mandou aplicar aos doentes os remédios necessários, e como as armas não estivessem em estado de com elas poderem resistir, ser a gente pouca, e haver perdido parte do mantimento por causa das chuvas, tornou para Jamimbu, onde chegou à 5 de junho ( ...)." (Apud MOREIRA NETO, 1971, p. $\frac{\text { 217- }}{217}$ 219)。

o texto expoe claramente os traços que marcavam as relações entre os Xavante e os agentes dos interesses na- 
cionais. Por parte dos Xavante, fica claro que queriam manter sua liberdade e independência, uma vez que o contato que haviam experimentado com o's brancos foi profundamente negativo aos olhos dos Xavante. Da parte da "civilização" ficam igualmente claras as intenções para o contato: desimpedir a região cara a ampliação da coloñização; utilização de força armada para alcançar os objetivos; uso de grupos indígenas para alcan çar os intentos, fossem estes grupos diferentes ou pertercentes ao mesmo tronco linguístico e cultural, como no caso; a forma como o Estado e a ação missionária se uniam buscando a adequação dos interesses dominantés da irente de expansão(40). Outra notícia que provavelmente envolve os Xavante situa-se no período em que a atividade do extrativismo vegetal, fundado na borracha, possibilitou uma retomada, breve mas intensa, da expansão econômica em todo o norte do centro-

(40) A série de contatos hostis dos Xavante com os brancos foi profundamente marcante na visão de mundo tribal, a ponto da tradição oral, conservada ainda hoje mesmo pelas gerações mais jovens, só ver possível o contato a partir do momento em que os Xavante passaram a pacificar os brancos, ou "amansar o Waradzu" como dizem. Na tradição oral está sintetizada na lenda "A Pacificação dos Brancos", relatada por GIACCARIA E HFIDE (I975b, p。139-145).

Em entrevista recente de Mário Juruna ao "Pasquim",' o contato com os civilizados foi assim explicado ao jorna lista: "(...) Então Xavante fugiu muito. Agora Xavante não pode fugir mais. Xavante tá cansado dê-fugir. No rio das Morte foi nós, índio, que atraiu branco. Branco tinha medo da gente. Então a gente procurou branco, sem flecha, sem borduna, com mulher e criança. Mesmo asฐim, branco tinha medo da gente, mesmo depois da gente ter sido ex-.pulso da cabeceira do rio Xingu. Deu muito trabalho a gen te atrair branco. Branco sempre com medo. Foi uma luta' amansar branco。( (...)" (MARTINS, 1982, p. 209)。 
-oeste, com o crescimento da importância dos rios navegáveis, das rotas comerciais, e dos caminhos terrestres de ligação entre as províncias. Com esta atividade, a economia rural de algumas regiões foi revitalizada, voltarido o indio a constituir um empecilho ao "desenvolvimento". A notícia consta do relatório do presiderte da Província de Mato Grosso, CARDOSO JR., de 1871, em que relata que ra região que liga Mato Grosso a Goiás, todo o trecho entre "Sanzrador" e o rio Araguaia, é considerado perigoso e inseguro pelos colonos (Apud MOREIRA NE TO, 1971, p。 163-164).

Julgando as informações como corretas, o trecho a que se refere o relatório compreendido ertre o "Sangrador" e o rio Araguaia, situa-se ao longo da margem direita do rio das Mortes e no sentido oeste-leste ou oeste-nordeste até o rio Araguaia, acabava por xenetrar em território Xavante. Esta ampla área constituía, na época, habitat de vários grupos tribais: dos Bororo, ao sul, indo depois ao longo do vale do rio Garças até o Araguaia; dos Kayapó ao norte, da margen esquerda dos formadores do rio das Mortes, depois pelo divisor de águas, até tomar a região dos formadores do rio Culuene e por este acima; dos Xavante, no vale compreendido pelo Araguaia e das Mortes (NIMUENDAJU, 1981, mapa anexo)。

O relatório trata de forma suposta a autoria dos ataques, já que consta terem sido promovidos primeiro por "coroados", depois cor "Caia oó". Não consta que a região tenha si do habitada por "Coroados", podendo desta forma referir-se indistintamente por este nome aos Bororo, que eram, porém, sobejamente conhecidos pelos agentes do Estado nessa épocá, como aos Xavante。A designação "Caiapó" poderia referir-se tanto aos Kayapó própriamerte ditos, como também a outro grupo que 
manifestasse hostilidade para com o contato com os brancos. Em qualquer caso, a prohabilidade das hostilidades também envolverem os Xavante é muito alta. Interessa constatar, porém, que a ação indigenista no período, adequando-se aos interesses dominantes representados pela frente extrativis ta, com seus apêndices comerciais e agro-pastoris, era de neutralização dos grupos indígenas que opusessem resistêrcia à o cupação econômica. Esse objetivo fica plenamente caracterizado pela possibilidade de instalação de destacamentos militares em diversos lugares, não havendo informações posteriores de terem sido instaladas ou não.

Outra notícia envolvendo possivelmente os Xavante é de 1886, ano em que o engenheiro José Feliciano Rodrigues de MORAIS, a serviço do presidente da Província de Goiás, subiu no vapor Araguaia setenta e duas léguas do rio das Mortes, desde sua confluência com o Araguaia até o porto Rodovalho. Nesse local, a missão cumpriu seu objetivo ao encontrar-se com outra expedição que havia partido em 30 de março de 1887, com onze praças do exército e dois civis, comandados pelo capitão Antônio Tupy Ferreira Caldas, da capital da Província de Mato Grosso. Essa segunda expedição desceu o rio das Mortes num total de duzentas léguas até o mesmo porto, onde encontrou o marco da expedição goiana, terminando sua missão. Pelas infor- " mações, no retorno, tiveram problemas com índios e, embora não conste o nome da tribo, são interpretados como Xavante, pela descrição dos índios e da borduna usada como arma de guerra e de arremesso, por RAVAGNANI (1978, p。133-134 e 144 - nota 43) e, antes, por souzA (1953, p. 17-18).

Nos últimos anos do século XIX, há outra notícia de tentativa de pacificação dos Xavante bravios do rio das 
Mortes, tarefa que coube ao dominicano Frei Gil Vilanova. Partiu com uma canoa, remadores contratados e víveres. Entretanto, ao atingir a foz do rio das Mortes, os remedores se recusaram a continuar viagem, devido ao terror que tinham daqueles índios (RAVAGNANI, 1978, p。134).

Até o final do século XIX os Xavante conseguiram manter-se relativamente isolados do contato com os brancos, ainda que tenham sido observadas algumas hostilidades e enfrentamentos provocados por tentativas de penetração no território tribal do grupo. Porém, essa atitude e autonomia tribal só era possível na medida em que o capitalismo ainda não havia se desenvolvido plenamente no Brasil, notadamerte no setor agrário, possibilitando a existência de vida social não subordinada aos mecarismos de reprodução ampliada do capital, e por isso mesmo, poderdo manter-se pré-capitalista, ou mantendo uma organização econômica, política e social não-capitalista.

Durante a primeira metade do século XX, quarido se observa uma nova frerte de expansão econômica no cenưro-oeste, movida pela exploração pecuária, que impunha o controle, posse e ocupação das terras habitadas pelos Xavante, todo o período se transformou num campo fértil de hostilidades e de massacres promovidos contra os índios, malgrado a política indigenista protecionista e a existência de um aparato institucional do Estado destinado a fazer cumprir o protecionismo (4l). A medida

(4I) o Serviço de Proteção aos Indios (S.P.I.) foi criado em 20 de julho de 1910, através do Decreto no 8072。 Em 15 de novembro de 1911, pelo Decreto 9214, era fixada as linhas mestras da política indigenista brasileira que propunha respeito às tribos indígenas e a sua forma de vida e costumes, proteção ao índio em seu habitat, etc。 
que os interesses econômicos da frente pecuária passam a capitalizar os ânimos do Estado e das Missões, todos os esforços se concentraram na "pacificação" do grupo tribal, objetivo alcançado pela equipe coordenada pelo sertanista Francisco Meirelles que passou a atuar a partir de 1944, conseguindo o primeiro contato em 1946, e em 1949 o principal Erupo Xavante já estava dentro do Posto Indígena Pimentel Barbosa.

Reduzidos os Xavante em Postos Indígenas, toda essa região estava agora aberta à ocupação do capital, tendo as agências do Estado bem cumprido o papel de instrumento a serviço dos interesses dominantes。

Para terminar o presente item, é interessante observar que muito se escreveu, na época, buscando interpretar a ação de hostilidade desses índios para com a "civilização", geralmente explicada pela imagem traiçoeira que guardaram do branco da época em que as primeiras bandeiras os atacaram impiedosamente, ou quando foram maltratados nos aldeamentos oficiais. Dois autores exemplificam: Egon SCHADEN, na "apresentação" da obra de GIACCARIA e HEIDE (1972, p. 7 e 8), e Darcy RIBEIRO (1977，p。65-68). O primeiro interpreta a hostilidade Xavante como produto da ação dos "desbravadores do sertão" em séculos passados:

"Até há dois decênios persistia na tradição xavánte a imagem do branco traiçoeiro como reminiscência de episódios que em séculos passados marcaram a história da invasão do território tribal pelos des bravadores do sertão.Por muito tempo essa imagem manteve nos Xavánte um espírito agressivo diante do mundo dos bran- 
cos, o que Ihes garantia a independência e também a integridade de sua cultura. Afinal pacificados e atraídos ao ccnvívio ccm o homem civilizado, são talvez a tribo jê em que hoje se acentua mais o ritmo das influências pertuoadoras desse convívio." ( SCHADEN, 1972, p. 7 )。

Para Darcy RIBEIRO a hostilidade dos Xavante, depois de voltar a ocupar seu antigo território foi consequencia da experiência que tiveram nos aldeamentos:

"(..) Ali os Akwẽn tiveram oportunidade de conviver intimamerte com guarnições militares e de experimentar a vida civilizada。 Não devem ter apre ciado a experiência, porque lō go depois, começaram a escapar rimö ao Norte, para o antigo território tribal. (...) Um grupo que denotava maior aversão ao convívio dos civilizad $s$ e que passou a ser conhecido como Xavante ( o.) (RIBEIRO, 1977, p. 65)。

Evidentemente que a experiência que tiveram com represertantes da sociedade nacional, deixou uma imagem totalmente negativa desta, förnecendo-lhes o sustentáculo ideo lógicc para o isolamento e hostilidade para com a ocupação econômica de seu habitat。 Crê-se, porém, que a explicação não pode se limitar aos aspectos ideológicos, culturäis ou sociais, mas tem que ser buscada na recuperação da totalidade 
que a situação envolvia (42).

\subsection{A Questão da Origem Tribal dos Xavante}

Como foi dito anteriormente, há sobre os Xavante no século XIX uma questão teórica poîêmica: se refere à origem dos Xavante enquanto grụo tribal e à explicação dada para a sua suposta origem. De modo geral, a produção antropológica recente, funajada em relatos do século XIX, explica a origem do grupo afirmando que esses formavam, juntamente com os Xerente, um único grupo tribal, denominado Akuên. Os Akuên habitavam originalmente a bacia do Tocantins, desde o sul de Goiás até o Maranhão, estendendo-se do são Francisco ao Araguaia. Após os contatos com a civilização. Na aldeia do Carretão os Akuên

(42) Com relação ao estigma de índios bravios e traiçoeiros, é de se observar que os Xavante têm consciência de que o objetivo da sociedade nacional é neutralizar suas ações agressivas. Isso faz com que esses índios utilizem a seu favor os estereótipos que contra eles existem secularmente, mantendo assim um certo grau de autonomia e de afastamento dos nacionais. Mas áreas próximas às Rs. Is. os agentes da sociedade nacional (fazendeiros, posseiros, etc。) conservam a opinião de que os Xavante são traiçoeiros e assassinos, ficando sempre temerosos de um mal entendido com eles ou de que invadam e ataquem as fazendas e ou posses。

Os estereótipos contra o índio acabam, assim, adquirindo um duplo sentido para os próprios Xavante: por um lado, são utilizados pelos próprios Xavante para dar vazão à agressividade que reprimem em relação aos brancos: por outro lado, servem para manter uma certa-distância entre o grupo tribal e os brancos.

Essa mesma situação havia sido observada por IARAIA e da MATTA (1979, p。177-179) em relação aos Gaviões。 
retornaram ao seu antigo habitat, passando a haver uma polarização de opiniões sobre o contato, gerando duas facções: uma denotando simpatia pela manutenção do contato com os brancos; a outra, manifestando verdadeira aversão ao convívio com os civilizados. O grupo que manifestava simpatia continuou a viver no território tradicional, passando a ser conhecido como Xerente; a facção que denotava aversão iniciou em direção ao Araguaia uma imigração, hostilizando os colonizadores e passou a ser chamada de Xavante.

Não se trata de uma simplificação da argumentação utilizada, mas a própria arguição dada, conforme se pode inferir de três conhecidos autores que tratam da questão.

Para a autora de o fndio na História do Brasil, a questão é exposta da seguinte maneira:

"( ...) Os Akwen, que ocupavam a bacia do Tocantins, desde o Sul de Goiás até o Maranhão e do rio São Francisco ao Araguaia, tinham sido atingidos, primeiro, pelos bandeirantes faiscadores de ouro, os criadores de gado e finalmente os seringueiros. Em 1785, cerca de 5 mil índios foram aldeados pelo governador de Goiás junto a um estabelecimento militar. A experiência não deve ter sido boa, porque anos mais tarde a aldeia de Carretão ficou deserta, retornando os índios ao seu território tradicional. Os Akwen dividiram-se, então, em dois grupos. 0 mais arredio, conhecido como Xavante, emigrou para a margem esquerda do Tocantins, em 1824, depois para o Araguaia (1859) e finalmente para o rio das Mortes, 
em Mato Grosso. Defendeu seu território, mantendo em pânico tanto as populações indźgenas como as sertanejas vizinhasaté que foi pacificado por Francisco Meireles, funcionário do S.P.I。 em 1946。 A outra divisão dos Akwen, os Xerentes, instalou-se na margem direita do Tocantins. Mostraram-se menos hostis que os Xavante e em 1870 começaram a ser catequizados por Frei Antônio de Ganges, capuchinho. Não demorou muito para que moradores sertanejos se apossassem das terras dos Xerente. Formou-se o arraial Tereza Cristina, rebatizado Piabanhas, gerando graves conflitos entre Indios e sertanejos. O próprio imperador Pedro II teve de intervir, destinando uma reserva para usufruto exclusivo dos Xerente. Nela havia excelentes pastagens e os moradores não tardaram a ocupá-las com seu gado. Até hoje os Xerente reclamam as terras doadas pelo imperador, que até entrou em seus contos místicos como um herói ancestral。( BEIRO, 1983, p。73-74).

Essa exposição é praticamente a mesma dada por Darcy RIBEIRO em Os Indios e a Civilização, sendo que a primeira é uma simplificação da argumentação desse autor. Embora não acrescente nenhum fato novo, far-se-á abaixo a citação literal dessa interpretação, dada a importância de seu autor na comunidade acadêmica:

"A história dos Akwên repete a 
dos Timbira。( ..) Ocupavam originalmente a bacia do Tocantins, desde o sul de Goiás até o Maranhão, estendendo-se do rio São Francisco ao Araguaia. Antes de enfrentarem os criadores de gado que os alcançaram vindos do Oeste, do Norte e do sul, tiveram de fazer face às bandeiras e aos garimpeiros que devassaram seu território em busca de ouro e diamantes. Sua oposição aos civilizados foi tão tenaz que eles chegaram a ser responsabilizados pela decadência de Goiás .

Entraram em relações pacíficas com os brancos em 1785 quando um governador de Goiás cumulou de brindes e honrarias um grupo de índios aprisionados e os devolveu às suas aldeias com propostas de paz. Os Akwên que se mantinham até então irredutíveis acorreram à capital da provincia, surgindo ali um número de três mil e quinhentos para estabelecer-se junto dos cristãos.

Para acomodá-los foi organizado o aldeamento de $D$ 。 Pedro II ou Carretão, com casas arruadas, dotado de um engenho de açúcar e controlado por um estabelecimento militar vizinho. Ali os Akwên tiveram oportunidade de conviver intimamente com guarnições militares e de experimentar a vida civilizada. Não devem ter apre ciado a experiência, porque logo depois, começaram a escapar rumo ao Norte, para o antigo território tribal. Anos 
depois o aldeamento que dizem ter concentrado cinco mil índios, estava praticamente deserto e os Akwên reiniciaram suas hostilidades。Um grupo que denotava maior aversão ao convívio com civilizados e que passou a ser conhecido como Zavantes, começou a deslocar- se para a margem esquerda do Tocantins ( 1824 ), depois para - Araguaia (1859) acabando por se estabelecer nos campos do rio das Mortes. Dali partiam em assaltos às populações sertaneja e indígenas das vizinhanças, mantendo-as em pé de guerra até há poucos anos.

$$
(\ldots \circ)
$$

Os Akwên, que voltaram a se fixar no seu antigo território, à margem direita do Tocantins, passaram a ser conhecidos como Xerente. Estes grupos revelaram maior disposição para conviver com os civilizados. Por volta de 1870 foram procurados em suas aldeias por um capuchinho, frei Antônio de Ganges, com o propósito de catequizá-los. Aos poucos foi-se concentrando em torno da igreja e da casa do missionário uma população sertaneja que invadia, lentamente, com seus rebanhos os campos de caça dos indios, formando-se um arraial chamado Tereza Cristina, hoje Piabanhas." (RIBEIRO, 1977, p. 64, 65 e 66).

Se os dois autores já citados simplificam a questão, não documentando e fundamentando as explicações e análi- 
ses formuladas, o mesmo não ocorre com a tese de doutoramento que leva o título A Experiência Xavante com o Mundo dos Brancos。 RAVAGNANI (1978) faz uma ampla exposição fundamentada em relatcs de viajantes e descrições etnográficas do século XIX e do atual, acabardo pox chegar, em linhas gerais, à mesma formulação dos dois autores citados; porém, com uma scfisticação na argumentação.

Inicia afirmardo que não há dúvida de que os Xavante e Xerente viveram na segunda metade do século XVIII no centro e norte da Província de Goiás, e que "parece terem formado um único grupo chamado Akuen。(...)" (Idem, p. 99).

Baseando-se en citações de EHRENREICH, José Feliciano de OLIVEIRA, Basílio de MAGAIHÃEs, Darcy RIBEIRO, VIAICHER, COUDREAU e VIANNA, conclui que as tribos em discussão:

"... são divisões de um único grupo ə que na época dos depoimentos relatados, início do século XIX, formavam dois grupos distintos mas culturalmente muito próximos。(...) o que nos leva a crer numa ruptura recente e não violenta tendo em vista que continuaram habitando o mesmo território embcra em aldeias separadas, e de se unirem algumas vezes formando uma frente única aos colonizadores ou tribos hostis。 ( ...)" (Idem, p。100-101).

Em seguida, o auton passa a explicar o motivc que teria levado os Akuên à cisão e à saída de uma parte deles. Novamente baseado em citações de COUDREAU, MAYBURY-LEWIS, Hermano $R$ 。da SILVA, DUROURE, AUDRIN, Darcy RIBEIRO, AURELI, Amí car A. B。 MAGALEÃES, PATERNOSTRO e outros, e fazendo a distinção entre cisão e separação, conclui que foram as frentes de 
expansão que causaram a cisão tribal (Idem, p. 102-104). A separação se deu após a fuga do Carretão, sendo asşim exxlicada:

"Uma vez experimentado 0 convívio com os colonizadores, as opiniões devem ter se polarizado, pois quase à mesma época deparamos com uma facção que desceu à procura do governador Fernardo Delgado Freire de Cas tilho, pedindo-lhe para serem aldeados, e isto em 1810. Apesar da recusa do governador voltaram carregados de brindes. Três anos depois, outra facção, com provas de hostilidades, atacou o presídio de Santa Maria. Era quando os favoráveis se mantinham em seu território indiferentes ou até desejosos pelo contato com os "civilizados", enquanto aqueles que se recusavam a isto, com grande mobilidade horizontal procuravam se afastar, espalhando-se pelo norte da província, atacando arraiais, fazendas e aldeias... A estes os colonizadores ccmeçaram a thes chamar de Xavante e por suas atitudes deram-lhes os adjetivos "feroses", "bravios", "bárbaros"... Aos outros chamaram-lhes de Xerênte.

Os primeiros foram se concentrando paulatinamente na margem squerda do Tocantins, mais resguardada, já que a frente pastoril descia a margem direita, mais próxima dos criadores das Províncias da Bahia, Piaú e Maranhão. Os Xerênte mansos se envolveram relativamente, nesta época, com os nacionais. Os Xavânte 
bravios continuaram à procura de um habitat seguro que encontraram a oeste, e aos poucos foram se aglomerandc nas margens do Araguaia até transpô-lo, continuando sempre sua marcha até o rio das Mortes." (RAVAGNANI , 1978, p。105-106)。

Após sua lonøa argumentação ccnclui que os dois blocos devem ter se formado lo so depois da fuga do Carretão no início do século XIX, se concretizando no final da primeira década. Na segunda década, estavam já divididos em "mansos" e "bravos", mas habitando o mesmo território. A medida que as frentes de expansão avançam, começam a se distanciar geograficamerte, indo um grupo em direção ao Araguaia e, posteriormente, fugindo do contato que não pretendiam (Idem, p. 106-107)。

A questão da origem tribal dos Zavante e/ou Xerente não tem importância alguma em si mesma, tendo em vista os objetivos do presente trabalho. Porém, é interessante sob duplo ponto de vista: por um lado, obriga a refletir sobre as explicações científicas que são dadas para um ferômeno qualquer, que vão sendo reproduzidas e acabam por se transformar em "verdade", que não são mais questionadas no âmbito da produção/reprodução do conhecimerto; por outro lado, obriga a recuperar determinada ordem explicada, extrapolando o fato $\mathrm{em}$ si mesmo e as informações que sobre ele se forjam, para dentro ainda de limites teórico-metodológicos buscar o entendimento da totalidade.

Do ponto de vista etnológico, é inquestionável a origem comum dos dois grupos, bem como de outros que compõem o grande tronco linguístico-cultural macro-jê e, particularmente, 
da família Jê. As questões defrontadas são outras: é possível se afirmar quando ocorreu a cisão do grupo? o material etnográfico e documental disponível possibilita que se faça inferência do período aproximado em que isso ocorreu? A explicação causal possui consistência?

Se as informações da tese da origem comum estiverem corretas, a ordem cronológica das ocorrências seria a seguinte: até início do século XIX formariam um único grupo tribal, sendo que as fontes documentais se refeririam a esses indios como Akuên; a partir da segunda década desse século occrreria a divisão, um grupo pasłando a manter relações pacíficas com os agentes da colonização ou, no mínimo, não mantendo confrontos hostis, sendo que passariam a ser denominados Xerente; no mesmo período e situação, outro grupo passaria a manter relações hostis com os colonizadores ou, no mínimo, os evitariam, passando a ser denominados Xavante. Quanto ao habitat, entre o final do século XVIII e primeira década do XIX, se localizariam na mesma região, mas em territórios contíguos; axós isso, os Xerente permaneceriam na margem direita do Tocantins, enquanto os Xavante se deslocariam para a margem esquerda, depois para o Arasuaia e finalmente para o rio das Mortes.

Conforme já se disse anteriormente, a maioria dos documentos referentes aos dois primeiros séculos de ocupação do território nacional tratam as populações indígenas genericameñe por "gentios", ou denominações similares, não se preocrpando em especificar o nome tribal. Por isso, até a metade do século XVIII não se encontra uma única referência sobre os Xavante, Xerente ou Akuên. Essa situação também é assinalada por RAVAGNANI (1978, p。13) que tenta tratar a situação provável do grupo tribal tomando por base as condições de ocupação 
do centro-oeste, sem especificar qualquer situação particular em relação a esse grupo tribal (Idem, cp。1-14)。

A primeira informação documentada, a carta do Governador D。 João Manuel de Mello, de 29 de dezembro de 1762, referia-se explicitamente aos Zavante. Toda a documentação posterior, já citada anteriormente, continuou a utilizar a nominação Xavante, o mesmo ocorrendo no documento referente ż"primeira pacificação". A documentação posterior referente aos aldeamentos ou às hostilidades cometidas por índios se referiam nominalmente aos Xavante e, quando fosse o caso, aos Xerente.

Revendo os documentos citados, não se encontrauma única referência aos "Akuên", antes, durante ou após a "primeira pacificação".A documentação posterior evidencia ainda outro aspecto da questão: com exceção dos índios Xavante ou Xerente aldeados, a hostilidade desses indígenas em reIação às frentes de exparsão econômica da sociedade nacional, e a repressão contra os mesmos, não afetou somente aos Xavante, mas igualmente aos Xerente, cuja hostilidade é apontada, por exerplo, no ano de 1838 e mesmo ainda em 1881, conforme consta do relatório do presidente da Província de Goiás, Leite Morais (Apud MOREIRA IETO, 1971, p。270 e s。).

Pelo exposto, não se encontra a menor sustentação na afirmação que esses índios eram Akuên, depois passaram a ser Xavante e Xerente. Da mesma forma, a explicação de que a cisão foi provocada por diferentes posturas em face do contato com o branco - dos Xavante, hostil; dos Xerente, amigável - não encontra respaldo nas fontes documentais que tratam das hostilidades promovidas por ambos os grupos. Evidentemente que a permanência Xerente numa região, em que a ocupação econômica 
se consolidava com maior rapidez que nas frentes de penetração, impunha ao grupo ou o extermínio ou a sibmissão, sendo que o grupo se submete, ao mesmo tempo que sofria drásticas conseqư̂encias provocadas pela depopulação. Na medida em que os Xavante optam pela fusa em direção aos sertões, ainda não atingidos pela expansão econômica, a. situaçãc será significativamente difererciada. Tão logo as frentes pioneiras da expansão os atingia, registravam-se novos conflitos. Vinha novamente a fuga; mes ccmo a exparñão e ampliação capitalista é contínua, logo os atingia. seguindo-se o conflito. Isto quer dizer que as condições conjunturais aue acabaram por afetar a cada um dos grupos tribais foram profundamente diferenciadas e erquanto tal é que devem ser analisadas。

Assim, as fontes de informação que acabam servindo de sustentículo à hipótese de que houve cisão, de que o nome da tribo era um e dexois passou a serem outros, etc. estão calcadas em relatos de viajantes, em informações etnográficas do século XIX e, principalmente, na sistematização acadêmica posterior. Em geral, os viajartes e etnógrafos do século XIX não estavam preocupados com a questão da fidedignidade da pesquisa científica - o que seria exigir demais deles; contentavam-se em relatar o que viam e ouviam, procurando interpretar as informações com base nas condições sócio-econômicas e teórị co-metodológicas possíveis para a época. Assim, vão-se encontrar análises de que os Xavante e os Xerente eram um mesmo grupo, assim postas:

"Pertencem ao grupo dos "Akuens" e são irmãos legítimos dos Cha vantes, hoje retirados nas regiões do rio das Mortes, mesmas feições, mesmes armas,mesmos enfeites e utensílio, e mesmo idioma também." (AJDRIN, 
apud RAVAGNANI, 1978, p。100)。

"Nenhum dos dois tem razão (o autor refere-se a Couto de $\mathrm{Ma}-$ galhães e a Coudreau), pois que acuen... tanto se aplica aos Chavantes, quanto aos Cherentes e recorre à autoridade de José Feliciano de Oliveira para explicar o termo: "Acuen ou a-cuên ou ac-uên significa a gente, humano, indivíduo da espécie humana o. " (BASILIO DE MAGALHÃES, apud RAVAGNANI, 1978, p。1.2 - nota 44)。

".. a palavra Xerente é corrupão (sic) de Xavante que então passara pela modificação vocabular obedecendo as leis lexicographicas que se formou, logo se deu a frąmentação da tribu。." (VIANNA, apud RAVAGNANI, 1978, p. 112 - no ta 44).

Com base nessas "informações" ou interpretações, além das posteriores, como a de Darcy Ribeiro, é que se conclui que ambos eram um mesmo grupo, os "akuên". Mas não pára nessas informações, pois a unidade Xavante-Xerente e as causas da cisão possuem outras informações:

"Hermano Ribeiro da Silva anota: 'Faz cerca de 80 annos uma das facções desta última nação - está se referindo aos Xerênte - ao fugir das tentativas de pacificação que se processavam nas alturas de Santa Maria, investiu para as margens do Araguaia, cujo leito transpoz..', informação esta obtida, segundo o autor, dos índios Karajá e catequistas." 
(SIIVA, apud RAVAGNANI, 1978, p. 103)。

"... para José Audrin, quando no século XIX a catequese do rio Tocantins se iniciou, a tribo já estava dividida, então uma parte 'consentiu em ficar entregue aos cuidados dos PP.Capuchinhos, enviados ali pelo Império. São justa-. mente aqueles que começaram a ser chamados Cherentes ...' 'Uma outra parte numerosa recusou a evangelização, atravessou o Tocantins e procurou as vertentes do Araguaia'." (AUDRIN, apud RAVAGNANI, 1978, p. 103).

"... alguns velinos Karajá relataram a Hermano que antigamente, durante o estio anual, moços guerreiros Xerentes atra vessavam o Araguaia e iam visitar os Xavante. Isto perdurou até que os chefes Xavantes proibiram estas visitas alegando que traziam doenças mortais dos cristãos." (RAVAGNANI, 1978, p. 114 - nota 72)

Não se crê que sejam necessários comentários maiores: ouvi dizer.., um velho Carajá contou..., informação dos catequistas..., um mito diz..., etc. Em que condições podem essas informações serem validadas? Os Carajá eram inimigos ferrenhos dcs Xavante, que invadiram e tomaram parte de seu território tribal; aos catequistas, enquanto agentes dos interesses dominantes, interessava reler os fatos em conformidade com as conveniências de sua obra cristianizadora.

Para que se possa analisar adequadamente essas 
"interpretações" históricas, as migrações de grupos tribais e uma origem explicativa de muitos dos grupos, é elucidativo um comentário de MOREIRA NETO (1971, p. 291), sobre esse tipo de produção do século XIX:

"(..) Em alguns cascs, a intencionalidade do uso de tais designativos (o autor se refere à distinção entre índios "civilizáveis" e "não-civilizáveis") se comprova pela tentativa de elaboração de uma Eseudo-história, pela qual se explicaria, através de pretensas migrações, a relação entre os dois ou mais dêsses grupos localizados em províncias muito distantes. Um exemplo característico é o da "origem" dos índios Canelas do Maranhão que c Bispo Azeredo Coutinho relaciona a uma pretensa migração dos Botocudos de Minas; derrotados pelos brancos e seus aliados Goitacá, em 1767 , teriam ido refugiar-se no Maranhão. Todos os sucessos, narrados com abundância de minúcias pelo Bispo, são absolutamente fantasiosas e destinam-se, explicitamente, a justificar expedições punitivas contra os Canelas. (...)" (MOREIRA NETO, 1971, p. 291).

A citação acima desvenda o caráter ideológico dessas "interpretações", em conformidade com os interesses dominantes, o que pode ter ocorrido perfeitamente no caso Xavante-Xerente, sem que os pesquisadores tenham se dado conta do fato。

É pelos motivos expostos que não se pode tomar 
essas interpretações envolvendo os Xavante como factualmente verídicas, mas como uma formulação que carece de fidedignidade e cuja reprodução pode comprometer a elaboração científica, caso não se façam as ressalvas necessárias ou os pesquisadores não exercitem a necessária criticidade, que a produção do conhecimento exige a todo momento。

"Nossos antepassados crią
ram o mundo em que estamos.
Transmitiram-nos informaçoses
acerca da circunstancia, con-
densadas nas setenças decla-
rativas que tratam das coisas,
de suas propriedades e das re-
lações que elas mantêm entre
si. As sentenças declarativas
que constituem a interpretação
da circunstância são transmi-
tidas de geração a geração,
pelas tradiços orais, pelas
salas de aula, pelos livros e
formam uma intricada rede em
que somos apanhados, sem mesmo
disso chegarmos a ter clara
consciência." (HEGENBERG, l974,
p. 3l).


7. CONCLUSÕES

o que se propôs estudar no presente trabalho foram as condições históricas de inserção dos índios Xavante no processo de desenvolvimento do capitalismo no Brasil, durante - período mercantil-escravista nacional, analisando-se o papel da política indigenista enquanto instrumento a serviço dos interesses dominantes。

Para que esta ampla problemática fosse estudada, distinguiram-se três ordens de questões: na primeira, tratou-se do desenvolvimento do capitalismo no Brasil; na segunda, estudcu-se a política indigenista engendrada em conformidade com os interesses dominantes do capital, em cada período econômico; finalmente, analisou-se o processo histórico por que passaram os Xavante, em vista da' expansão econômica e da política indigenista。

Pelo que se apresentou ao longo do presente trabalho, é possível concluir que tratar as sociedades indígenas de forma isolada e autônoma leva a uma distorção da realidade, pois os indígenas se inserem, de forma direta ou indireta, no processo de desenvolvimento histórico do capitalismo no 
Brasil. A caracterização dessa inserção pôde ser verificada pela reconstrução histórica dos Xavante e de sua relação com a colonização 。

Com a expansão da colonização, os Xavante foram privados de sua infra-estrutura econômica, perderam autonomia enquanto grupo, passando à formar uma configuração social que, direta ou indiretamente, dependiam dos interesses dos colonizadores. Essa dependência, realizada pela expropriação intensiva de seus meios de produção, obrigou-os a deslocamentos sucessivos, a fim de se apossarem de territórios onde pudessem desenvolver suas atividades produtivas e- reproduzir as condições de existência tribal.

Durante o período compreendido pelo presente trabalho, a supremacia dos colonizadores imprimiu às relações entre índios e brancos um caráter essencialmente colonial, mesmo quando essas se realizavam sob condições econômicas e políticas nacionais, sendo regidas pela oposição entre etnia colonizadora/etnia colonizada. Esta oposição étnica norteou a submissão dos Xavante aos interesses coloniais, quer pela expropriação de suas terras, quer pela exploração de sua força de trabalho. Nesse contexto, as migrações sucessivas, inda que tenham permitido a sobrevivência tribal do grupo, acabou transformando-os em reservatório dos interesses do capital sob duplo aspecto: por um lado, enquanto "reservas" de terra que poderia ir sendo apropriada na medida em que o capitalismo se ampliava e se desenvolvia no Brasil, por outro, enquanto "reserva" de mão-de-obra que poderia ser integrada à estrutura produtiva quando esta se efetivasse. De qualquer forma, esses processos caminharam lado a lado e representaram faces da mesma moeda: a subordinação das populações indígenas aos interes- 
ses do capital, sob as condições da economia colonial e mercantil-escravista nacional.

Essa inserção subordinadora não significou, porém, a destruição da identidade social dos indígenas, que permaneceram (e ainda permanecem) considerando-se e sendo considerados como índios pelos segmentos sociais coloniais e, depois, nacionais. Com isso, os Xavante, assim como outros grupos tribais, se inseriram na estrutura global da sociedade capitalista numa dupla situação: por um lado, enquanto grupo social pertencente ao -segmento social mais inferior da estrutura de classes; por outro, enquanto categoria social diferenciada por fatores econômicos, sociais e culturais, que participaram da economia regional de tal forma que as relações que estabeleceram com os demais segmentos sociais os transformaram em minoria e os colocaram numa situação de dependência. Nesse sentido, a subordinação dos indígenas ao capitalismo não significou a destruição de sua vida tribal, isto é: continuaram a existir enquarto formas de organização da produção não-capitalista (nesse caso, "primitiva")。Mesmo sofrendo o violento processo de expropriação de seus meios de produção e o extermínio de parcelas ponderáveis de sua população, sucumbindo frente às guerras ofensivas, bandeiras e conflitos, os Xavante continuaram a produzir e reprcduzir as condições para continuarem a ser Xavante, mantendo, assim, sua identidade tribal. Na medida em que esse prccesso de contínua produção e reprodução das condições para continuar a ser índio se dava com os Xavante, por sucessivos deslocamentos para novos habitat, o grupo teve que continuamente construir e reconstruir sua identidade tribal. Isso implicou a síntese dos vários elementos contraditórios que compõem o mundo tribal e o mundo capitalista, síntese esta 
construída pela reinterpretação, em confcrmidade com a visão de mundo desses indígenas, das situações históricas que os envolviam e dos novos padrões econômicos, sociais e culturais com que tinham que se defrontar.

Ainda que o próprio capital tenda a impôr às demais relações de produção sua categoria e sua importância, o que significa historicamente a subordinação às condições de reprodução ampliada do capital, isto não implica a eliminação das contradições, muito pelo contrário, é neste espaço contraditório que se realizam as condições de subordinação e de resistência das relações de produção não-capitalistas, à forma determinada de dominação do capital. Nesse asfecto, é de se destacar que a recuperação do processc histórico Xavante indica que a subordinação, por um lado, nem sempre se deu de forma direta - subordinação do trabalho ao capital - mas que mecanismos indiretos acabavam por impôr os interesses do capital; por outro lado, aponta para o fato de que as presumíveis formas de resistência - como a fuga, por exemplo- na verdade não passaram de mecanismos que o capital usou (e ainda usa) para expropriar as terras indígenas e ir penetrando em regiões que até então não estavam sob seu domínio. A resistência indígena não se caracteriza, assim, por sua aparência, mas pela manutenção de uma estrutura econômica que não é somente não-capitalista, mas anti-capitalista: a manutenção dos meios de produção como propriedade coletiva; a organização produtiva baseada em relações sociais de trabalho ccletivo ou cooperativc; a distribuição regida por mecanismos de reciprocidade, etc. Não se pode, porém, querer analisar esta contradição como a fundamental que acabará por provocar a transformação do modo de produção capitalista, marcando o axarecimento de um novo 
modo de produção. A contradição básica situa-se a nível da própria estrutura econômica dominante - é a contradição entre o desenvolvimento das forças produtivas que fassam a encontrar - limite de seu desenvclvimerto nas relações de produção capitalistas。

Tem-se que reconhecer, portanto, que a resistência indígena à penetração do capital, indicada pelas lutas contra a expropriação das terras, contra a proletarização, contra a desfiguração do mundo tribal, etc。, não indica a cons tituição de um ou mais modos de produção sob a dominância do capitalismo, mas uma luta esfecífica dessa categoria social, que procura manter a sua existência de acordo com a única forma que conhece e deseja: como índio. t́ possível que a resistência indígena acabe por ser engolida pela expansão capitalista, mas como a transformação histórica não se realiza de forma milagrosa e sim em conformidade com as práticas concretas dos agentes sociais, pode ser que a resistência indígena se mantenha, assuma proporções ainda maiores, a ponto de continuamente reproduzir suas formas de existência coletiva até que a transformação histórica da sociedade humana tenda a uma equalização das contradições vividas pela profunda desigualdade de existência das classes。

Muito se tem ainda a estudar sobre a questão indígena e o desenvolvimentc do capitalismo no Brasil. o corte histórico do presente trabalho, abrangendo os períodos econômicos de formação do capitalismo no Brasil - colonial e mercantil-escravista - implica por si mesmo a continuidade dos estudos, abrangendo o período mais recente: o da economia exportadora capitalista retardatária - desde 1888 até o presente. 
Esta será uma tarefa bastante árdua, pois abrangerá uma problemática das mais complexas. A nível econômico, a dominância passa a ser marcada pelo nascimento e consolidação do processo de industrialização. Ao lado da dominância do capital industrial e, depois, do financeiro, continuou o processo expansionista de ocupação econômica das regiões onde o capital industrial e, depois, do financeiro, implicou uma nova transformação da estrutura e organização do setor agrário. Ao desenvolvimento econômico corresponderá um agravamento nas relações entre índios e brancos, isto é: na política indigenista. A dimensão que a problemática indígena atingiu no período, ganhando proporções internacionais, exigiu a intervenção direta do Estado que organizou um aparato de Estado incumbido de regulamentar as relações entre as populações indígenas e a scciedade nacional, buscando o protecionismo ao mesmo tempo que salvaguardava a continuidade da expansão eccnômica e os interesses do capital. Essa medida não foi suficiente, porém, para por fim aos conflitos que continuaram a marcar a nossa história recente, caracterizados pelas mesmas situações do passado: a expropriação das terras indígenas pelo capital e a eliminação dos entraves que impediam a expansão. Neste novo quadro econômico e político reaparecem os Xavante. Primeiro, impedindo a ocupação econômica do planalto centro-oriental brasileiro pelo latifúndio criatório e, depois, agro-pastoril. Conflitos sangrentos envolvendo os índios Xavante e os agentes da colonização marcaram a primeira metade do século XX, até que ocorreu a pacificação do grupo, em meados deste século pelo Serviço de Proteção aos Indios. Estava, pois, aberta a região para a ocupação econômica, apoiada pela cobertura institucional do Estado que organizou para tanto a Fundação Brasil Central, prece- 
dida pela Expedição Roncador-Xingu. Com a efetivação da ocupação econômica, a problemática dos Xavante passará a ser de luta pela terra e pela manutenção de sua identidade.

Este vazio deixado pelo corte histórico do presente trabalho é evidente. É preciso que se reconheça, porém, que muitos foram os aspectos que não se conseguiram abranger e que poderão se constituir em problemas para novas pesquisas. A nível da estrutura econômica, os trabalhos disponíveis elucidam satisfatoriamente a dominância do capital, mas dado que as condições de rrodução se davam sob situações variantes em relação aos caminhos trilhados pelo capitalismo, enquanto modo de produção, é preciso que se estudem as formas concretas de organização da produção, e como estas se articulavam à estrutura econômica colonial e, depois, nacional, de modo a propiciar a acumulação. Aspecto profundamente ligado a este é a necessidade de estudos mais profundos sobre as relações sociais de produção. A forma dominante foi a escravatura, não há dúvida alguma, mas não era a única, posto que segmentos produtivos organizavam a produção de forma diferenciada da escravista . Outro aspecto que exige maiores pesquisas é com relação à contradição interna da economia colonial e da economia mercantil-escravista nacional. De modo geral, os trabalhos existentes, ainda que explicitem aspectos contraditórios, não chegam a fazer uma análise profunda da contradição que essas formas de realização econômica assumiram em relação ao desenvolvimento do modo de produção capitalista, bem como das contradições que se davam no interior mesmo da estrutura econômica da formação social brasileira.

Com relação à análise da política indigenista, a produção acadêmica se reduz a dois trabalhos, entre outros que 
tratam de modo geral e superficial, que aprofundam dois períodos históricos: de 1500 a 1640 (THOMAs, 1982) e o século XIX (MOREIRA NETO, 1971), Fica, assim, um vazio de praticamente dois séculos (XVII e XVIII) que necessitam de reconstrução histórica profunda e fidedigna. Os trabalhos citados, porém, deixam ainda lacunas que precisam receber a atenção dos pesquisadores. Com referência ao período que vai até 1640, é preciso que se pesquise a realização da política indigenista metropolitana de acordo com as regiões do território nacional que, em conformidade com a exploração econômica colonial, sejam problemáticas na relação entre índios e os agentes da colonização. Quanto ao século XIX, carece de sistematização a polı́tica indigenista desenvolvida nas regiões sudeste e sul, que do ponto de vista do capital foram regiões fundarnentais na medida em que foi na primeira que a economia mercantil-escravista cafeeira se realizou e, na segunda, se ampliou em decorrência da sua expansão. Vendo a questão a partir de pressupostos teórico-metodológicos que buscam a recuperação da totalidade histórica, a questão indígena carece, ainda, de trabalhos que resgatem de forma profunda toda a plenitude de situações (econômicas, ideológicas, jurídico-políticas) que envolvem a questão indígena.

Nesse contexto seriam muito úteis pesquisas que recuperassem a participação indígena enquanto força de trabaIho e enquanto uma categoria social que era e é parte integrante da estrutura social brasileira. Outra linha de pesquisa, igualmente importante e relacionada à anterior, refere-se ao estudo da ideologia dominante em relação ao índio como um contingente populacional estereotipado como "não útil enquanto força de trabalho"。 Os estudos que foram feitos nas páginas 
precedentes, ainda que perifericamente, demonstram que o indio foi útil e necessário como mão-de-obra, só sendo sabstituido na medida em que os interesses do próprio capital impunham o tráfico de escravos negros como uma das atividades básicas do comércio mercantil. Assim, a ideologia do índio "indolente" e "preguiçoso" só se justifica face a oütros interesses do capital, como por exemplo a expropriação de suas terras。

o presente trabalho, é, pois, uma contribuição, entre outras, para que a questão indígena seja estudada não por si própria, mas como uma ordem problemática que, historicamente, se insere no processo de desenvolvimento histórico da sociedade humana. Muito ainda, porém, está por se fazer e pesquisar. 
Titre: "LE XAVAN'TE ET LA POLITIQUE INDIGENISTE AU BRÉSIL AUX SIECLES XVIII E XIX". Auteur: José Claudinei Lombardi. Promoteur: Oriowaldo Queda.

Ce travajl est une étude des conditions historiques dinsertion des indiens "Xavantes" dans le processus du développement, au capitalisme au Brésil, aboutíssant aux conclusions suinartes: traiter les sociétés indigènes de façon antonome constitue une distorsion de la réalité, car les indigènes s'insèrent dans le processus de développement du capitalisme an Erésil.

Le cas des "Xavantes" met en évidence que I'exparsion de la colonisation a fait en sorte que les indiens formassent une configuration sociale dépendante des intèrêts des cclonisateurs. Ia suprématie de ces derniers a donné aux relations entre les indiens et les blancs un caractère essentiellement colonial; cette suprématie est régie par loposition "ethnie cclonisatrice"/"ethnie colonisée", orientant la sou- 
mission des "Xavantes" aux intérêts coloniaux et, ensuite, nationaux. Ces processus ont représenté la subordination des populations indigènes aux intérêts du Capital.

Cela n'a pas signifié, cependant, la destruction de l'identilé sociale des indigènes, qui ont continué à se considérer et à être considérés comme indiens. L'insertion des "Xavantes" dans 'la structure globale capitaliste a eu lieu, soit en tant groupe social appartenant à la couche la plus basse de la structure de classes, soit en tant que catégorie sociale différenciée, quoique dépendante. Nonobstant le fait de souffrir le violent processus d'espropriation de ses moyens de production et l'extermination de plusieurs parcelles de sa population, les "Xavantes" ont continué à produire et à reproduire les conditions nécessaires pour demeurer "Xavantes", conservant leur identilé tribale.

Ce processus a exigé que les "Xavantes" construissent et reconstruissent continuellement leur identité tribale, ce qui a impliqué la synthése des différents éléments contradictoires qui composent le monde tribal et le monde capitaliste, synthése élaborée par la réinterpretation des situations historiques dans lesquelles ils se trouvaient pris.

Le capital tend à imposer aux autres relations de prodution sa catégorie et son importance, ce qui n'élimine pas ses contradictions; c'est dans cet espace que se réalisent les conditions de subordination/résistance des relations de prodution non-capitalistes à la forme de domination du capital. La résistance indigéne ne se caractérise pas, ainsi, par som apparence, mais par la conservation d'une structure économique non-capitaliste qui s'oppose à la pénétration du capital. Cela n'indique pas la constitution d'un ou plusieurs mo- 
des de production sous la dominande du capital, mais une lutte spécifique de cette catégorie sociale qui cherche à maintenir son existence domme indienne. 
9. LITERATURA CITADA'.

ALANCASTRE, J.P., 1864。Estudos Históricos - Annaes da Província de Goyas, In: Revista do Instituto Histórico e Geográfico Brasileiro. Rio de Janeiro, Vol. 27.

ALBISETTI, C。e A. COLBACCHINI, 1942. Os boróros orientais orarimogodoque do planalto oriental de Mato Grosso. São Paulo, Nacional, Brasiliana, Série Grande Formato 4.

ALBISETTI, C。 e A.J.VENTURELLI, 1962。 Enciclopédia Bororo: Vocabulários e etnografia. Campo Grande, Museu Regional Dom Bosco, Vol.I I.

AZEVEDO, A., 1961。Geografia Humana do Brasil. São Paulo, Companhia Editora Nacional.

BAIDUS, Ho, 1945. Os Tapirapé. In: Revista do Arquivo Mrunicipal. São Paulo, 101, março de 1945, p.67-75.-

BAIDUS, H., 1970。 Tapirapé: Tribo Tupi no Brasil Central. São Paulo, Companhia Editora Nacional e Editora da Universidade de São Paulo.

BORELII, S.H.S。 e M.I.M. LUZ, 1984。Introdução。In: COMISSÃo 
PRO-INDIO DE SÃO PAULO, 1984. Indios no Estado de São Pau10: Resistência e Transfiguração . São Paulo, Yankatu Editora/Comi ssão Pró-Indio.

BRAVERMAN, H॰, 1977. Trabalho e Capital Monopolista。 Rio de Janeiro, Zahar Editora。

CANO, W., 1981. Raízes da Concentração Industrial em São Pau1o. 2a ed. São Paulo, T.A. Queiroz Editor.

CARDOSO, F。H॰, 1962. Capitalismo e Escravidão no Brasil Meridional. São Paulo, Difusão Européia do Livro.

CARDOSO, F.H., 1973. As Classes Sociais na América Latina. São Paulo, (exemplar mimeografado).

CARVALHO, E.A., 1979。 As Alternativas dos Vencidos: Indios Terena no Estado de São Paulo. Rio de Janeiro, Editora Paz e Terra.

CASTRO, A.M。 e E.F. DIAS, 1974. Introdução ao Pensamento Sociológico。 Rio de Janeiro, Livraria Eidorado Tijuca.

CASTRo, A.Bo, 1980. A Economia Política, o Capitalismo e a Escravidão. In: IAPA, J.R॰A॰, Org॰, 1980. Modos de Produção e Realidade Brasileira. Petrópolis, Vozes, p。67-107.

CosTA, E.V., 1966. Da Colônia à Senzala. São Paulo, Difusão Européia do Livro.

DOBE, M॰, 1981. A Evolução do Capitalismo. 8 ed. Rio de Janeiro, Zahar Editores.

FERNANDES, F。, 1960。 Ensaios de Sociologia Geral e Aplicada. São Paulo, Iivraria Pioneira Editora.

FERNANDES, F。, 1975. A Investigação Etnológica no Brasil e ou- 


\section{tros ensaios Petrópolis, vozes.}

FRANCO, M.S.C., '1969. Homens Livres na Ordem Escravocrata。 São Paulo, Instituto de Estudos Brasileiros.

FREUND, J., 1973. Les Theories des Sciences Humaines. Paris, Presses Universitaires de France.

FURTADO, C., 1982. Formação Econômica do Brasil。 18 ed. São Paulo, Companhia Editora Nacional.

GIACCARIA, B。e A。 HEIDE, 1972. XAVANTE: (Auwẽ Uptabi: Povo Autêntico). São Paulo, Editorial Dom Bosco.

GIACCARIA, B. e A.HEIDE, 1975a。 Jerônimo Xavante Conta. Campo Grande, MT, Publicação no 1 da "Casa da Cultura" .

GIACCARIA, B. e A.HEIDE, 1975b。Jerônimo Xavante Sonha. Campo Grande, MT, Publicação no 2 da "Casa da Cultura" .

GNACCARINI, J.C.A., 1972. Estado, ideologia e ação empresarial na agro-indústria açucareira do Estado de São Paulo. São Paulo, Universidade de São Paulo, (Tese de Doutoramento). GOIDMANN, I。, 1980. Ciências Humanas e Filosofia - o gue é a Sociologia. 8 ed. São PauIo, DIFEL-Difusão Editorial. HEGENBERG, L。, 1974. Explicações Científicas: Introdução à Filosofia da Ciência. 2a ed. São Paulo, Editora Pedagógica e Universitária e Editora da Universidade de São Paulo.

HINDESS, B。e P.Q。HIRST, 1976. Modos de Produção Pré-Capitalistas。 Rio de Janeiro, Zahar Editora.

HOFF, S., 1983 o Movimento da Produção de Excedentes numa Região Pioneira (Nas Pegadas do Trabalho: Café e Idéias). Maringa, PR, Universidade Estadual de Maringá, maio de 1983, (exemplar mimeografado)。 
HOORNAERT, E。 e outros, 1977. História da Igreja no Brasil. Petrópolis, Vozes.

HOORNAERT, E。, Org., 1982。 Das Reduções Latino-Americanas às Lutas Indígenas Atuais: IX Simpósio Latino-Americano da CEHIIA, Manaus, 29 de Julho à 01 de Agosto de 1981。 São Paulo, Edições Paulinas.

IANNI, 0., 1962. As Metamorfoses do Escravo são Paulo, (s. ed.) .

IANNI, O., 1962. "Raça e Classe". In: Educação e Ciências Sociais. Ano VII, Vol. 10, CB PE, Rio de Janeiro, JaneiroAbril de 1962 .

IANNI, 0., 1978. A Luta pela Terra: História social da Terra e da Luta pela Terra numa área da Amazônia Petrópolis, RJ, Editora Vozes.

IANNI, 0., 1980. Aspectos da Formação Social Escravista. In: LAPA, J.R.A., Org., 1980. Modos de Produção e Realidade Brasileira。 Petrópolis, Vozes, p。157-165.

KAUTSKY, K., 1980. A Questão Agrária. São Paulo, Proposta Editorial。

LAPA, J.R॰A., Org॰, 1980. Modos de Produção e Realidade Brasileira. Petrópolis, Vozes.

LAPA, J.R.A., 1982。 OAntigo Sistema Colonial. São Paulo, Brasiliense, (Primeiros Vôos 8 ).

LARAIA, R.B. e R。MATTA, 1979. Indios e Castanheiros: A Empresa Extrativa e os Indios no Médio Tocantins. 2 ed。Rio de Janeiro, Editora Paz e Terra. 
LENIN, V., 1982. O Imperialismo: Fase Superior do Capitalismo. 2 ed. São Paulo, Global.

LONBARDI, J.C。 e M。 NAKAMURA, 1981. Organização Social da Produção dos fndios Kaingang e Guarani de Mangueirinha: uma Contribuição à Discussão da Problemática Agrária。 Limeira, SP, Instituto superior de Ciências Aplicadas, (exemplar mimeografado)。

LOMBARDI, J.C., 1983. Uma Nova Abordagem para a Questão Indígena. In: Universidade e Sociedade. Maringá, PR, Universidade Estadual de Maringá, Ano 1, no 1, dezembro/1983.

LOMBARDI, J.C., 1985. A questão Indígena e o Desenvolvimento do Capitalismo no Brasil (Estudo da Experiência Xavante com - Mundo dos Brancos, desde a Economia Colonial à Mercantil-Escravista Nacional - Século XVI ao XIX)。 (Relatório de Pesquisa)。(não publicado).

MANTeGA, G., 1984. A Economia Política Brasileira. São Paulo, Polis/Petrópolis, Vozes.

MARTINS, E。, 1982. Nossos Indios, Nossos Mortos. 4a ed。 Rio de Janeiro, Editora Codecri.

MARTINS, J.S., 1980。 Expropriação e Violência: a questão política no campo. São Paulo, Editora Hucitec.

MARX, K., 1981. Formações Econômicas Pré-Capitalistas。 3 a ed. Rio de Janeiro, Paz e Terra.

MARX, ․, 1982. O CAPITAL - Crítica da Economia Política - Livro I, Volume I。 São Paulo, DIFEL-Difusão Editorial.

MARX, K。, 1982. O CAPITAL - Crítica da Economia Política - Livro I, Volume II。 São Paulo, DIFEL-Difusão Editorial. 
MARX, K。, 1980. O CAPITAI - Crítica da Economia Política - Livro II, Volume III。Rio de Janeiro, Editora *Civilização Brasileira。

MARX, K., 1980。 O CAPITAL - Crítica da Economia Política - Livro III, Volume IV. Rio de Janeiro, Editora Civilização Brasileira。

MARX, K。, 1981。O CAPITAL - Crítica da Economia Política - Livro III, Volume V。.Rio de Janeiro, Editora, Civilização Brasileira.

MARX, K॰, (s.d•). O CAPITAI - Crítica da Economia Política Livro III, Volume VI。Rio de Janeiro, Editora Civilização Brasileira.

MARX, K., 1983. Contribuição à Crítica da Economia Política. 2@ ed. São Paulo, Martins Pontes.

MAYBURY-LEWIS, D., 1967。Akwé-Shavante Society. Oxford, Carendon Press。

MELATTI, J.C., 1980。 Indios do Brasil。3 ed. São Paulo, Editora Hucitec; Brasília, Instituto Nacional do Livro.

MELLO, J.M॰C。, 1975. O CAPITALISMIO TARDIO (Contribuição à Revisão Crítica da Formação e Desenvolvimento da Economia Brasileira). Campinas, Universidade Estadual de Campinas, (Tese de Doutoramento).

Monteiro, J.M., 1984. Vida e Morte do fndio: São Paulo Colonial. In: COMISSÃO PRÓ-fNDIO DE SÃO PAULO, 1984。 fndios no Estado de São Paulo: Resistência e Transfiguração. São Paulo, Yankatu/Comissão Pró-fndio de são Paulo.

MOREIRA NETO, C.A., 1971. A Política Indigenista Brasileira 
Durante o Século XIX. Rio Claro, Faculdade de Filosofia, Ciências e Letras de Rio Claro (Tese de Doutoramento).

MULLER, R。A.P., 1976. A Pintura do Corpo e os Ornamentos Xavante: Arte Visual e Comunicação Social.Campinas, IFCH, Universidade Estadual de Campinas (Dissertação de Mestrado) NIMUENDAJU, C., 1981. Mapa Etno-Histórico de Curt Nimuendaju. Rio de Janeiro, Secretaria de Planejamento da Presidência da República, Fundação Instituto Brasileiro de Geografia e Estatística, Secretaria de Cultura do MEC e Fundação Nacional Pró-Memória.

NOSELLA, M.L.C.D., 1981. As Belas Mentiras: a ideologia subjacente aos textos didáticoso 5 a ed. São Paulo, Moraes.

NOVAIS, F.A., 1981. Portugal e Brasil na Crise do Antigo Sistema Colonial, São Paulo, Editora Hucitec.

PALACIN, L., 1972. Goiás 1722/1822.... Goiânia, Oriente/Departamento Estadual de Cultura.

PRADO JR。, C., 1979. Formação do Brasil Contemporâneo (Colônia)。 16a ed. São Paulo, Editora Brasiliense。

PRADO JR., C., 1982。História Econômica do Brasil。27 a ed. São Paulo, Editora Brasiliense.

RAVAGNANI, O.M., 1978. A Experiência Xavante com o Mundo dos Brancos. São Paulo, Escola de Ciências Sociais, da Fundação Escola de Sociologia e Política de são Paulo (Tese de Doutoramento).

RIBEIRo, B.G॰, 1983。 O Indio na História do Brasil。 São Paulo, Glo bal . 
RIBEIRO, D., 1977. Os Indios e a Civilização - A Integração. das Populações Indígenas no Brasil Moderno. 2a ed. Petrópolis-RJ, Editora Vozes.

SCHADEN, E., 1972. Apresentação。In: GIACCARIA, B。 e A。 HEIDE, 1972. Xavante (Auwẽ Uptabi: Povo Autêntico). São Paulo, Editorial Dom Bosco.

SCHADEN, E., 1977. Homem, Cultura e Sociedade no Brasil: Seleções da Revista de Antropologia. 2a ed. Petrópolis, RJ, Vozes.

SILVA, J。G., 1982. O Que é Questão Agrária. 5a ed. São Paulo, Brasiliense (Coleção Primeiros Passos, 18).

SILVA, L.M.L.A., 1976. No Limiar da Industrialização - estado e acumulação de capital, 1919-1937. Campinas, SP, Instituto de Filosofia, Ciências Humanas, da Universidade Estadual de Campinas ( $T e s e$ de Doutoramento).

SILVA, M.A.P.I., 1980. NOMES E AMIGOS: da prática Xavante a uma reflexão sobre os jê. São Paulo, Departamento de Ciências Sociais, Faculdade de Filosofia, Letras e Ciências Humanas, da Universidade de São Paulo (Tese de Doutoramento).

SILVA, S., 1980. Expansão Cafeeira e Origens da Indústria no Brasil。 3a reimpressão, São Paulo, Editora Alfa-Omega.

SINGER, P.I., 1968. Desenvolvimento Econômico e Evolução Urbana. São Paulo, Nacional e EDUSP.

THOMAS, G., 1982。 Política Indigenista dos Portugueses no Brasil: 1500-1640. São Paulo, Edições Loyola.

VILLAS BOAS, O. e C. VILLAS BOAS, 1975. XINGU: Os Indios e seus Mitos. São Paulo。 Editora Edibolso. 


\section{APÊNDICE}

APÊNDICE I: Legislação Indigenista no Período Colonial.

Conteúdo básico da legislação indigenista aprovada ou promulgada no período colonial (*).

- O primeiro decreto real sobre a política indigenista brasileira data de 15ll. O regimento do Rei D. Manuel I, datado de 22 de fevereiro de 15ll, foi dirigido ao capitão do navio "Bretoa".Além de recomendações técnicas, determinava a conduta da tripulação em relação aos indígenas que a expedição haveria de encontrar nas costas brasileiras: proibição estrita de ofender, de algum modo, os indígenas ou de causar-Ihes prejuízo. Estabelecia penas extraordinariamente duras aos delituosos: a perda da metade dos salários e, de acordo com a categoria do delinqtente, castigo que correspondesse ao delito.

(*) Os dados básicos sobre a questão foram compilados de: HOORNAERT e outros (1977); NELATTI (1980); RAVAGNANI (1978); RIBEIRO (1977); RIBEIRO (1983); THOMAS (1982)。 
- Em 02 de junho de 1537, o Papa Paulo III, edita a Bula "sublimis Deus", onde declarava os índios verhadeiros homens e Ihes reconhecia a capacidade de aceitar a fé cristã. Proibia - Papa a escravização e espoliação de todos os índios convertidos ou pagãos.

- Data de 1549 o Primeiro Regimento do Governo Geral do Brasil, onde fica explicitado que a conversão indígena constituía o motivo principal do povcamento do Brasil, recomendando que os nativos fossem bem tratados e que thes fossem concedida toda a reparação, nos casos em que sofressem algum dano. Ao mesmo tempo, o documento permitia que se desse combate aos índios inimigos, sob o argumento de "guerra justa", sendo os mesmos mortos ou feitos prisioneiros.

- Im 20 de março de 1570 o Rei D. Sebastião promulgou a primeira lei sobre a liberdade dos índios brasileiros. Contudo, a lei real proporcionava a liberdade completa unicamente a uma parte dos indígenas; aprovando uma escravidão controlada, justificando a escravidão indígena sob a dupla suposição de "guerra justa" e da prática de antropofagia.

- Em 06 de janeiro de 1574 uma Junta criada pelo rei D. Sebastião para acurar os reclamos dos colonos contra a lei de 1570, decidiu pela probição da escravidão dos índios que viviam junto aos portugueses ou nos aldeamentos jesuíticos; reconhece a aquisição lícita de escravos índios para os casos de guerra justa, resgate e auto-alienação。

- Em 24 de fevereiro de 1587, D。Felipe II, outorga uma lei 
tentando resolver as oposições dos colonizadores contra os jesuítas, resolvendo manter os padres da Companhia de Jesus na administração das aldeias. Esta lei confirma a validade da lei de 1570, quanto à questão da escravização, porém, esta lei determina medidas para possibilitar aos colonos o recrutamento de mão-de-obra indígena, sem contudo Ihes tirar a liberdade, isto é, índios livres poderiam ser contratados pelos colonos, recebendo salário correspondente.

- Em 22 de agosto de 1587, D. Felipe II editou um Decreto: os índios deveriam viver nas aldeias como "súditos livres do Rei", poderiam adquirir terras próprias e estariam à disposição dos colonos, de acordo com as necessidades.

- Em 11 de novembro de 1595 o rei D. Felipe II voltou a definir em lei a "guerra justa": todos os índios que não fossem escravizados como prisioneiros de uma expedição guerreira ordenada pelo Rei deveriam poder viver "...em sua liberdade natural, como homens livres que são sem poderem. ser como cativos constrangidos a cousa alguma"。

- Em 26 de julho de 1596 nova lei fez definitivamente dos jesuítas os responsáveis principais da política indigenista no Brasil. Entregou-lhes com exclusividade a tarefa de recolher os índios do sertão e de fazê-los assentar-se na costa, nas vizinhanças dos estabelecimentos europeus. o trabalho indígena passava a ser regulamentado: cada colono podia empregar os indígenas em seus estabelecimentos por dois meses, no máximo; essas mesmas condições foram estendidas aos padres. Para a inspeção da aplicação da legislação foram criados dois 
ofícios: o "procurador de índios" e o "juiz de índios", o procurador tinha função apenas consultiva, enquanto o juiz teria competência para uma "decisão legal" no caso das disputas entre índios e colonizadores。

- Em 1605, o rei D. Felipe III, determinou em lei que somente os índios antropófagos e os prisioneiros de guerra declarada pelo governo deveriam ser considerados como escravos e todos os demais gente livre。

- A lei de 30 de julho de 1609, que seria aplicada ao Estado do Maranhão, recém criado, explicitava que os índios eram homens livres, não só os convertidos à fé cristã, como também os gentios; que não seriam compelidos a trabalhos forçados ou deslocados de seu habitat contra a sua vontade; se engajados em trabalho dos colonos, receberiam salários; que teriam direito a suas terras e propriedades, podendo comerciar livremente com os moradores; que os escravos índios fossem imediatamente libertos; finalmente, a lei dispunha que aos jesuítas ficavam confiadas a proteção dos índios, a missão de buscá-los e repartí-los ao serviço público e particular。

- Em 10 de setembro de 1611, D. Felipe III, pressionado pelos colonos brasileiros que não só continuaram a praticar a escravidão, mas a apresentar como causa propicia e até necessária aos interesses da Coroa, legislou que a liberdade dos índios era reconhecida em tese. Reputou legítimo cativeiro os índios aprisionados em "guerra justa", autorizando os colonos a comprarem aos índios os prisioneiros destes "resga- 
te". Aconselhava, ainda, a criação de colônias correcionais sob a ingspeção dos brancos. Concedeu aos colonos a co-responsabilidade na administração das aldeias, criando a instituição de Capitães leigos, a quem caberia o governo temporal das aldeias. Finalmente, os capitães assumiram também a anterior tarefa dos jesuítas de ganhar para os novos estabelecimentos os índios do sertão。

- Em 1639, dado o violento massacre que os colonos promoviam com os indígenas brasileiros, notadamente as bandeiras paulistas que atacavam as missões jesuíticas no extremo-sul do país, o Papa Urbano VIII editou uma nova Bula, de 22/04/ 1639, na qual reafirmava a do Papa Paulo III(de 28/05/1537), ameaçando com a excomunhão aos que incorressem no cativeiro e venda de índios. A publicação desta Bula provocou um levante dos colonos de São Paulo, que acabaram expulsando os jesuítas desta capitania em 1640. A reintegração dos mesmos se deu em 1643, por Carta Régia。

- Em 20 de março de 1642, D. João IV baixou nova lei proibindo a escravidão dos índios.

- Im 10 de novembro de 1647, dadas as atrocidades cometidas pelos colonos no Norte da Colonia, a Coroa expediu um Alvará, em que reconhecia a liberdade dos índios, eliminava as administrações e os administradores, mas estabelecia que os índios poderiam livremente servir e trabalhar com quem bem lhes parecesse e melhor pagasse por seu trabalho.

- Em 1653 chegava ao Maranhão o Padre Antonio Vieira com ins- 
truções da Corte para entregar aos jesuitas a questão inaígena, demonstrando as intenções de que se queria mesmo restaurar a liberdade dos índios. A reação dos colonos foi das mais exacerbadas, com acusações aos inacianos no sentido de que estes usavam em rrovieito próprio e exclusivo o trabalho indígena. Com esta reação, o governo português, através da Provisão de 17 de outubro de 1653, reinstalou a escravidão nos casos de "guerra justa" e de "resgate"; introduziu, ainda, dispositivos que impediam qualquer índio de escapar do cativeiro.

- Em Iisboa, o Padre Vieira conseguiu a revogação, em rarte, da Provisão de 17 de outubro de 1653. Assim nova legislação era outorgada em 1655, conservando-se "os quatro antigos casos de escravidão", ficando revogadas as demais, e novamente as entradas ao sertão, a repartição dos escravos apreendidos, foram entregues aos jesuítas. Essa legislação pôs, ainda, nas mãos da missão jesuítica, o julgamento sobre as circunstâncias em que o índio poderia ser escravizado。

- A reação dos colonos não se fez esperar. Desta feita foram os governadores os coagidos a modificar esta lei, culminando com a expulsão dos inacianos em 1661, porque estes combatiam a caça humana ilegal.

- o poder dado anteriormente aos jesuítas passou a ser ques tionado não somente por colonos, mas também pelas demais ordens religiosas. Com isto, tem-se novo retrocesso。 Através da lei de 12 de setembro de 1663, era retirado o poder temporal dos jesuítas sobre os índios e o poder espiritual pas- 
sou a ser dividido entre as demais ordens religiosas.

- Em 1679 foi renovada a proibição do tráfico vermelho, os Jesuítas foram repostos no poder temporal, sendo-lhes entregue a administração e cura dos índios. Isto significou que os índios foram entregues à tutela dos Jesuítas que procuraram fundar numerosos aldeamentos e dividiram com outras ordens religiosas a "civilização dos índios".

- Em Ol de outubro de 1680, D. Pedro II, rei de Portugal, baixou novo Alvará, restaurando, em parte, a legislação anterior, favorável à Companhia de Jesus e aos índios. Essa lei definia os índios como "primários e naturais" senhores da terra. Abolia totalmente a escravidão, embora ainda se tenha disposto sobre a divisão dos índios em três partes: uma ficaria nas aldeias para tratar da lavoura, subsistência pró pria e dos índios descidos de novo; a outra seria distribuída entre os moradores; e a terceira se agregaria aos padres da Companhia de Jesus para os acompanharem ao sertão"。

- Em 02 de setembro de 1684, no entanto, outra lei restabelecia as "administrações particulares" dos índios。

- Em 1686 os jesuítas retornaram ao Maranhão, sendo sua atuação definida na Carta Régia e Regimento das Missões, datados desse ano, no qual estes padres teriam de dividir o poder espiritual e temporal sobre os índios com outras ordens religiosas。

- A penetração estrangeira fez com que recrudescesse novamente 
a questão do aprovisionamento de índios, que passaram a ser necessários não só como trabalhadores, mas também como guerreiros. Assim, em 1688, renovaram-se as expedições de resgate: o Índio que não fosse considerado aliado era imediatamente acusado de "inimigo" e passível de "guerra justa". As expedições particulares voltaram a ser autorizadas e o aprisionamento, antes clandestino, passou a fazer-se abertamente, sendo os índios arrastados aos engenhos e às propriedades agrícolas dos colonos。

- Em 21 de abril de 1702, através de Carta Régia, o governo português deu proibição expressa ao cativeiro indígena. Fazia exceção apenas à sua administração, por tempo limitado, a quer voluntariamente pacificasse os índios.

- Em 09 de março de 1718 era editada nova lei, que mais uma vez justificava os aprisionamentos e a escravidão.

- Em Carta Régia de 10 de junho de 1726, voltava-se a reafirmar a proibição da escravidão indígena, embora permitisseas governadores dar os índios a salário a pessoas de reconhecida confiança。

- Em 1744, O Papa Benedito XIV editou uma Bula na qual proibia, sob pena de excomunhão, o cativeiro, fosse secular ou eclesiástico 。

- Em provisão de 08 de maio de 1746, criou-se em São Paulo uma junta de missões com a finalidade de regular todos os assuntos concernentes aos índios. A 17 de junho de 1747 deu vá- 
rias providências acerca dos aldeamentos. A 30 de maio de 1753 ordenou que se enviassem os índios domesticados com seus respectivos missionários ao centro das tribos selvagens para "chamar seus irmãos à civilização".

- A Bula papal de 1744, porém, só foi implementada por decisão do homem forte de Portugal na época, o Marquês de Pombal, que pela lei de 06 de junho de 1755, extingiu o cativeiro dos índios。

- Pela lei de 28 de maio de 1757, as aldeias foram elevadas a vilas e criou-se o regime do Diretório, que substituía a tutela missionária pela do Estado, representado por um funcionário secular. O Diretório dos Indios, porém, não alterara o regime anterior: o Diretor recebia um sexto do produto das expedições de que participavam índios por ele tutelados. Com isso, incrementava-se, novamente, as atividades de coleta, em detrimento das agrícolas, porquanto umas e outras dependiam do b̈raço indígena, cada vez mais escasso.

- Em 1758 foi aprovado um regimento que promulgava as últimas leis do Marquês de Pombal em favor dos índios, a ponto de se rem consideradas como a principal legislação do período colonial. Essa legislação reconhecia os índios como livres, sem nenhuma ressalva; ordenava a restituição de seus bens; dava preferência para ocupar os cargos públicos aos mestiços de brancos e índios; proibia apelidá-los de caboclo ou negro; retirava o poder temporal dos missionários, sendo que os indígenas ocupariam os cargos locais em suas respectivas aldeias. Criava o cargo de Diretor de fndios, que seria no- 
meado pelos governadores para cada aldeia, tendo por objetivo que estes orientassem os indígenas na adoção dos gostumes dos civilizados。

- Pela lei de 03 de setembro de 1759, os jesuítas foram expulsos do reino e de seus domínios, os seus bens foram sequestrados em favor do Estado. Os inacianos haviam cumprido o seu papel como agente colonizador: a ocupação do território estava consolidada e a soberania da Coroa. não corria mais perigo。

- Em 1798, através de nova lei, era suprimido o cargo de Diretor de Indios. Devido à série de irregularidades e abusos cometidos pelos próprios diretores. Esta lei mantinha a liberdade dos índios, mas dava-Ihes o estado de menor. 
APÊNDICE II. Legislação Indigenista do período Mercantil-Escravista Nacional

Ainda que seja possível identificarem-se os traços característicos que permaneceram no transcorrer de todo o período compreendido entre o processo de decadência da economia colonial e de constituição da economia mercantil-escravista nacional, da consolidação e crise desta, como: as guerras de extermínio contra indígenas e a expropriação de suas terras, existem especificidades nas linhas gerais que assume a política indigenista, conforme se pode verificar pelo conjunto das leis do período ${ }^{(*)}$ :

- Carta Régia de 12 de maio de 1798 abole e extingue os dispositivos do Diretório Pombalino。A lei propõe como objetivo a integração do índio à sociedade colonial; porém, determina a organização dos índios em corpos de trabalho, estabelecendo-se determinado número de anos em que deveriam servir obri-

(*) As fontes consultadas para a exposição das leis desse período foram: MOREIRA NETO (197I, Parte II); RIBEIRO (1983) e MELATTI (1980)。 
gatoriamente; determina, ainda, que os índios que não possuam estabelecimento próprio ou ocupação fixa sejam compelidos ao trabalho público ou particular. Proíbe a "guerra ofensiva" aos índios, mas permite adotar um sistema "defensivo" - que, no fundo, significa a mesma coisa. Iibera o comércio com os índios a todos, proibindo-se a introdução entre eles de arma "e tudo mais que possa dar-lhes ocasião de intentarem empregar contra os seus "benfeitores". As terras indígenas passam a ser livres para a exploração de qualquer recurso natural, bem como para a sua ocupação por colonos brancos.

- Carta Régia de 13 de maio de 1808 ordena a guerra ofensiva contra os Botocudos de Minas Gerais e que se considere a todos os índios "Botocudos", pegos de armas nas mãos, como prisioneiros de guerra, ficando os mesmos a serviço do comandante por 10 anos, ou "pelo tempo que durar sua ferocidade e antropofagia" 。

- Carta Régia de 05 de novembro de 1808 ordena as mesmas providências contra os índios Kaingang de São Paulo, estabelecendo que os "prisioneiros de guerra", tomados por milicianos ou particulares, poderão destiná-los ao trabalho pelo prazo de 15 anos.

- Carta Régia de 1ㅇ de abril de 1809 reitera as normas para a campanha contra os índios de Minas Gerais. Introduz alguns outros dispositivos: autoriza a entrada de bandeiras, oficiais ou particulares, desde que com permissão do Comandante da Província; estabelece o cativeiro durante 15 anos, a con- 
tar do dia em que forem batizados; às expedições deverão fazer parte 2 religiosos, aos quais caberá ${ }_{e}$ catequese e batismo, a competente certidão, ratificando a condição de escravo dos índios apreendidos.

- Carta Régia de 13 de julho de 1809, dirigida ao governador da Capitânia de Minas Gerais, reafirmando que as áreas antigamente ocupadas pelos Botocudos fossem imediatamente distribuídas em sesmarias aos novos colonos para povoá-las e cultivá-las "... como o principal objeto das saudáveis providências que já tinha ordenado e continuaria a dar em benefício dos Povos dessa Capitania..."

- Carta Régia de 05 de setembro de 1811, em que aprova o plano do Desembargador Joaquim Theotônio Segurado, de estabelecimento das comunicações entre Goiás e Pará e da colonização dos territórios incultos que se estendem entre as duas Capitanias. Aprova a constituição de uma sociedade de comércio, com todas as facilidades e privilégios para a implantação da navegação no rio Tocantins e o estabelecimento de colônias ao longo desse rio. Em caso de ocorrer conflitos entre os colônos e os índios, franqueia as mesmas "graças" e "privilégios" concedidos aos Povos da Capitania de Minas Gerais, principalmente contra as "nações Apinagé, Chavante, Cherente e Canoeiro", pois "... não resta, presentemente, outro partido a seguir senão intimidá-las, e até destruí-las, se necessário for, para evitar os danos que causam". Aos índios que se mostrarem "fiéis vassalos" determina "... usar de toda a moderação e humanidade, procurando convencê-los da utilidade que lhes resultará de se conservarem em boa inteli- 
gência..."

- Carta Régia de 24 de março de 1819 trata da "civilização dos índios denominados Kayapó, habitantes do sertão do Rio Paraná, defronte da Barra do Tietê". Manda reservar-lhes uma légua de terras e nomear um diretor para os aldear e dirigir na forma do Diretório do Pará. Do mesmo modo que os Kayapó meridionais, trata dos índios de diversas Vilas do Ceará, Pernambuco e Paraíba, dispensando-os do pagamento de diversos subsídios impostos e quotas à Fazenda Pública e aos Diretores, pois esses índios "。otendo consideração à fidelidade e amor à minha real pessoa contra a minha real soberania"。

- Decisão no 210, do Ministério da Guerra, de 26 de setembro de 1825, refere-se à nomeação de Comandante e força das bandeiras contra os índios selvagens da Província de Goiás.

- Resolução de 18 de outubro de 1825, do Ministério do Império, recomenda ao Presidente da Província do Espírito Santo, a adoção de medidas para prevenir o uso de força militar contra os índios Botocudos do Rio Doce e de que se empregue as maiores diligências para com os índios, facilitando-lhes auxílio e "... abatendo-se de quaisquer atos de barbaridade e vingança, e promovendo, por todos os meios possíveis de brandura e afabilidade, a sua total civilização ..." 。

- Decisão de 20 de dezembro de 1825, do Ministério da Marinha, aprova a criação de uma companhia de índios para o serviço do Arsenal da Marinha do Maranhão e dos navios da Armada. Rạ 
tificando medidas adotadas desde o período colonial, estabe- lece a adoção de conscrição coercitiva de índios jovens ao Arsenal, porém, estes são empregados não só em navios da Armada e em Arsenais, como na navegação fluvial dos vários rios da Amazônia e Maranhão。

- Provisão da Mesa do Desembargo do Paço, de 20 de dezembro de 1826, face às queixas e representações dirigidas pelos Índios da Província do Rio Grande do Norte sobre a usurpação de suas terras e pedindo a reintegração de posse de parte delas, decide pela garantia das terras aos agricultores que as expropriaram.

- Decisão no 59, do Ministério da Justiça, de lo de março de 1830, declara que os índios devem ser governados pela legislação geral do Império (Constituição de 1824).

- Lei de 27 de outubro de 1831 revoga as Cartas Régias que mandaram fazer guerra e pôr em servidão aos índios; desonera todos os índios do cativeiro; passa a considerar os índios como "órfãos", passando a responsabilidade sobre eles aos Juízes de Órfãos.

- Decreto da Regência de 03 de junho de 1833, nos termos da lei de 1831, encarrega os Juízes de Orfãos dos Municípios respectivos da administração dos bens dos índios.

- Decreto no 4, de 18 de junho de 1833, isenta do pagamento dos dízimos e demais tributos aos indivíduos que se estabelecerem nas margens do rio Arinos e manda suprir com gados 
e instrumentos agrários o aldeamento do Salto Augusto e ou-

- tros que se fundarem nas margens do referido rio.

- Decreto de 06 de julho de 1833 cria na Província de Minas Gerais, um colégio de educação destinado à instrução de índios jovens de ambos os sexos. Nesse colégio deverão ser ensinados os dogmas da religião cristã, os princípios de educação civil e moral, as primeiras letras, ofícios mecânicos, princípios de aritmética e gramática brasileira.

- Em outro Decreto de 06 de julho de 1833, manda estabelecer, no Lago dos Tigres, Província de Goiás, um porto de embarque para o Pará e formar ali, com índios não civilizados, uma povoação com o nome de Porto Vermelho. Estabelece que para ali deverão ser mandados os "índios não civilizados" de São José de Mossamedes e do Carretão.

- Decreto no 285 de 24 de junho de 1843 autoriza o Governo a mandar vir da Itália missionários capuchinhos e distribuí- Ios pelas Províncias, em Missões。 As medidas adotadas nesse decreto dão aos capuchinhos o controle sobre a política indigenista do Império, não somente no que se refere à atividade missionária, mas à própria execução e direção das medidas oficiais para com os Índios. Esse decreto autoriza o governo a fazer as despesas necessárias cara a vinda dos missionários, bem como para sua distribuição pelas Províncias: autoriza, ainda, a criação de seis Loterias cujo produto seria aplicado na aquisição ou construção de prédios, capelas e demais instalações necessárias para o estabelecimento da Ordem, bem como para as despesas extraordinárias com as Mis- 
sões a serem implantadas.

- Lei no 317 de 21 de outubro de 1843, o legislativo autoriza - Governo a reunir e metodizar a legislação dispersa sobre indígenas num único instrumento legal, onde deveriam ser tra tados os princípios básicos da catequese e civilização dos mesmos。

- Decreto no 373, de 30 de julho de 1844 estabelece que a distribuição dos missionários capuchinhos fica dependendo do Governo Imperial; tudo o que disser respeito ao ministério sacerdotal, os padres estarão subordinados unicamente aos Bispos, ou ao Superior local da Ordem, onde existirem; ficam os missionários proibidos de solicitar ao superior Geral de Roma o desligamento da Missão ou transferência para outro lugar que não tenha sido designado pelo Governo.

- Decreto no 426, de 24 de julho de 1845, em que outorga o dis posto na lei no 317. Dispõe sobre a nomeação de um Diretor Geral dos Indios, nomeado pelo Imperador, e da nomeação de um Diretor para cada aldeia, bem como demais quadros considerados necessários (tesoureiro, almoxarife, cirurgião, pedestres, oficiais de ofício, etc.)。Estabelece, também, a presença de um missionário, pelo menos, em cada aldeia. As idéias básicas do decreto são: atração dos índios selvagens e conversão dos índios ao cristianismo, proibindo-se expressamente o uso da força e violência para a atração dos índios às aldeias; educação religiosa e instrução primária, a cargo dos missionários; prevê-se, também, instrução dos índios nas artes mecânicas, promovendo-se o estabelecimento de oficinas 
nas aldeias, mas, mais particularmente, o aproveitamento deles na cultura ou lavoura; demarcação dos distritos das ${ }^{c}$ aldeias e das terras concedidas aos índios, em comm ou separadamente; os índios podem de simples usufrutuários virem a ser proprietários; proteção aos índios, quer em suas pessoas e liberdades quer em seus contratos, quer em seus serviços, quer em suas terras; quando necessário, proteção militar aos Índios e às aldeias; proibição de serem dados a serviço particular, porém, mantém a tradição colonial de recrutamento de índios para as obras públicas; estabelece garantia de jor nais ou salários aos índios, quando chamados a serviço público ou da aldeia, etc.

o Diretor Geral e os Diretores das aldeias são constituídos procuradores dos índios, podendo nomear quem os represente perante a justiça e autoridades. Entre as atribuições do Diretor Geral de Indios, está a de conseguir os recursos necessários para a lavoura e comércio. Também cabe a ele informar ao Governo Imperial sobre a conveniência da conservação ou remoção dos aldeamentos, ou a reunião de dois ou mais aldeamentos num único. Feito isto, cabe ao mesmo Diretor indicar ao Governo o destino que se deveria dar às terras que foram abandonadas espontaneamente pelos indios ou desocupadas por efeito da disposição anterior. Compete ao mesmo Diretor Geral, a decisão sobre a transferência de populações indígenas inteiras e o estabelecimento dos modos e critérios de demarcação das terras indígenas. Cabe, ainda, determinar a porção das terras que deve ficar reservada para as plantações dos índios, bem como a porção delas que posæam ser arrendadas。 
- Lei no 601, de 18 de setembro de 1850 - a "Lei de Terras" divide o território brasileiro em "terras públicas", as terras de domínio do Estado, e ".terras particulares", provenientes de um título legítimo de propriedade ou de uma simples posse legalizada. As terras consideradas "devolutas" só poderiam ser apropriadas mediante a compra e a venda, sendo que o rendimento dessas transações deveriam ser destinados pelo Governo kara promover a vinda de imigrantes europeus para o Brasil. As terras expressamente concedidas aos índios foram consideradas como "terras particulares", estabelecendo-se a exigência de que toda e qualquer propriedade seja demarcada e titulada, tanto as obtidas por compra e . venda como as provenientes de um título legítimo de propriedade ou de simples posse legalizada. Das terras consideradas "devoIutas", a lei determina que deveriam ser reservadas áreas para a colonização indígena, afirmando-se o princípio do direito do índio ao território de suas aldeias. Autoriza, porém, o governo a vender as terras devolutas como e quando julgar mais conveniente.

- Decisão do Ministério do Império, em 21 de outubro de 1850, portanto um mês após a aprovação da "Lei de Terras", mandando incorporar aos próprios nacionais as terras dos índios que já não viviam aldeados, mas sim dispersos e confundidos na massa da população civilizada. Essa decisão, dirigida ao presidente da Província do Ceará, assim coloca a questão: "... por julgar não poderem ter mais aplicação ao fim a que foram originalmente destinadas... em consequência de não existirem aí hordas de índios selvagens... mas somente descendentes deles confundidos na massa da população civiliza- 
da..."

- Aviso de 02 de janeiro de 1854, dirigido pelo Ministério do Império ao presidente da Província do Maranhão, respondendo afirmativamente à consulta sobre recrutamento compulsório de indios para o trabalho público e particular。 Não considera Iimitativa, também, a permissão de se promover, como no passado colonial, o descimento de índios de todas as idades e sexos para o serviço dos lavradores.

- Decreto no 1318, de 30 de janeiro de 1854, manda executar a Lei no 601, de 18 de setembro de 1850. Anexo ao decreto há um longo e detalhado regulamento para a execução da lei, a fim de promover e facilitar as transferências de terras públicas ou devolutas para o domínio privado, prevendo-se os atos jurídicos e outras providências que consagrem definitivamente o direito pleno de propriedade sobre as mesmas.

= Decreto no 2747, de 16 de fevereiro de 1861, dá execução à Lei no 1067, de 28 de julho do ano anterior, que criou o Ministérios dos Negócios da Agricultura, Comércio e Obras Públicas, ao qual passam a ficar sujeitos os problemas que eram da competência do Ministério do Império. Entre esses, estão os registros de terras possuídas, a legitimação ou revalidação das posses, sesmarias ou outras concessões do Governo Geral ou das Províncias; a concessão, medição, demarcação, descrição, distribuição e venda de terras pertencentes ao Estado. Do novo Ministério passa também a depender a competência sobre "colônias militares" e das "colônias penais". Finalmente, a Pasta da Agricultura passa a abranger, 
também, a catequese e civilização dos índios e as missões e aldeamentos indígenas。

- Decreto no 1808, de 20 de agosto de 1870, autoriza o Governo a subvencionar a navegação a vapor no rio Araguaia e a tomar outras providências em benefício da mesma.

- Decisão no 276, de 20 de agosto de 1870, do Ministério da Agricultura, cria no. Araguaia um estabelecimento sob a denominação de "Colégio Izabel", destinado à instrução religiosa e profissional dos meninos das diversas tribos daquela região 。

- Decisão no 277, do Ministério da Agricultura, na mesma data, dando providências para o estabelecimento de uma missão encarregada da catequese da tribo Cambio.

- Decisão do Ministério da Fazenda, de 16 de abril de 1872 , contrária à pretensão de índios da Aldeia de são Pedro, em Cabo Frio, de pensões para a educação superior de seus fiIhos. Ao mesmo tempo destacai que a legislação visa "... proteger e tratar dos índios pobres e da educação de seus filhos, a qual não deve ser outra senão a que consiste na instrução primária..." 。

- Decisão no 127, do Ministério da Agricultura, Comércio e Obras Públicas, de 08 de março de 1878 , recomenda que se deva declarar extintos os aldeamentos que estiverem abandonados, cedendo uma parte aos índios que ainda nela permanecerem, dando-se às terras o destino determinado. Essa decisão 
destina-se ao Presidente da Província do Paraná。

- Decisão no 306, do Ministério da Agricultura..., de 17 de maio de 1878, dirigida ao Presidente da Província do. Paraná, aconselha que se consiga convencer, por meios persuasórios, aos índios de Guarapuava, de aceitarem as terræis que thes foram marcadas, devendo as demais. ficarem sob domínio particular. Recomenda, ainda, já que não é competência do Governo Imperial, que se procure o Governo da Província para a criação de foŗas regulares para fazer a guarnição dos Iugares em que fazendeiros se sintam ameaçados pela invasão de suas terras por índios。 
AP⿳ิNDICE III - Relato da "Primeira Pacificação" dos Xavante

A "primeira pacificação" dos Xavante, ocorreu entre 1784 e 1788, durante o governo de Tristão da Cunha. O comando da expedição foi confiado a José Rodrigues Freire que, por causa de uma queda do cavalo, deixou o comando ao alferes Miguel de Arruda e Sá. A expedição contava com 98 soldados, vários intérpretes e um grupo de Kayapó da aldeia de São José Mossamedes. Dada a importância do evento, segue abaixo alguns trechos que o historiam.

"Debaixo das ordens do novo Comandante continuou a nossa Bandeira a sua marcha até encontrar os bárbaros homicidas, que afincamente regeitaram tôdas as propostas de paz,....

Capacitando-se pois o Comandante da impossibilidade de trazer à razão aquêle gentio indócil e tenaz, mais por uma errada suspeita, que por fereza de gênio, procurou para dar cumprimento às expressas recomendações do Excelentíssimo Capitão General aprisionar alguns indivíduos daquela rebelde nação, o que fàcilmente conseguiu pela destreza do doméstico gentio Caiapó, que levava em sua companhia, e que voluntariamente nos acompanhava nesta expedição, desejoso de combater protegido das nossas armas com os índios Xavantes, aos quais havia jurado um antigo, e irreconciliável ódio. Concluída felizmente esta ação marchou para a Capital o Alferes Arruda, levando prisioneiros consigo a um va- 
lente Xavante, quatro Índias, e algumas crianças da. mesma nação.

A sua chegada encheu de inexplicável júbilo o humano coração de $\boldsymbol{S}$. Excelência por ver satisfeitos os seus desejos, e uma parte das suas experanças.

Iogo pôs em liberdade os prisioneiros, e os tratou, com o maior carinho, e afabilidade, para que perdendo a opinião, que erradamente formavam da sua tirania, convertessem em amor o ódio, que nos tinham, e preferissem viver conosco nas nossas urbanas habitações, que com as feras nas suas rústicas aldeias.

Ao Índio Xavante honrou com o nome de Tristão da Cunha, ação que grandemente encheu de vaidade o amor próprio daquêle bárbarc, que apesar da sua grossería, e brutal educação, sabia conhecer os obséquios, e não era insensível às aten ções, com que o tratava o grande Cacique dos Brancos.

Passados alguns meses dispôs o Excelentíssimo Capitão General ao novo Tristão da Cunha a partir para a sua terra natal, encarregado de fazer certa a sua nação do humano acolhimento, que em nós achara, para que despida das erradas preocupações, em que vivia a nosso respeito, se resolivesse a deixar as suas brenhas e a vir participar entre os brancos dos doces frutcs da sociedade civil, ficando dêsse modo em perpétuo esquecimento tôdas as hostilidades, que nos haviam feito, e todos os crimes, que contra nós haviam aleivosamente perpretado.

Disposto, o novo Tristão a partir, prometeu à 'S. Excelência o desabusar inteiramente a sua nação do mau conceito, que de nós fazia.

$$
(\text { o..) }
$$

Apresentando-se o Índio Tristão na sua aldeia, onde já tinha sido chorado várias vêzes por morto, a sua nação não pode dar crédito ao que via, nem ao menos às proposição que êle fazia a nosso respeito; mas tomado por traidor à Pátria, correu grande risco a sua vida; finalmente depois de grandes debates, e de alguma sorte convencidos das instâncias do grande Tristão, assentaram voltar êste com um seu irmão, e algumas índias a darem parte à $S$. Exceléncia, que êles aceitavam a paz, e se dispunham a vir render-lhe obediência, e que assim the mandasse fazer lavouras na paragem, onde haviam de ser aldeadcs, e que no verão futuro os mandasse enccntrar com mantimentos na travessia de Amaro Leite, cuja campanha é inteiramente falta de caças.

Nesta certeza tendo S. Excelência destinado o sítio do Carretão, distante desta Capital vinte e duas léguas, 
para ali fundar a nova aldeia, a qual estabeleceu com o nome de Pedro III, S. Excelência se dispôs a mandar fazer tôdas as necessárias plantações para a subsistência doś novos hospedes. No princípio do verão tornou $V$. Excelência a incumbir ao Tenente de Dragões Manoel José de Almeida o marchar com uma escolta de pedestres, e índios da nação Caiapó, e alguns Acrôas, para the servirem de intérpretes a encontrar no sertão de Amaro Leite com o gentio, (...) não vendo vestígio algum de chegar o dito gentio, mandou ao Tristão com uma escolta a explorar a campanha, a té quie finalmente encontraram com um lote de guerreiros, que andavam em montaria, e os conduziram à presença do Tenete, que os acariciou, quanto the foi possível, afim de animá-los a irem buscar a sua gente que ele vinha receber com os precisos socorros; voltaram os ditos índios, e dali a poucos dias percebeu o dito Tenente ter nas suas vizinhanças grande número de gentio todo de guerra, e pela sua experiência alcançou nos que o vinham visitar, achando- o com pouca saúde, e poucas forças que eles se dispunham a surpreendê-1o: o dito Tenente tomou as precisas precauções, procurando desvanecer ao gentio do receio, que ainda conservava a nosso respeito, vindo no conhecimento, que um índio Acrôa os tinha posto de ma fé。

o Cacique Caiapó, que ali se achava, lcgo que o Tenente acabou a sua prática, principiou a sua, dizendo ao Xavante, que êle tinha conhecido, tanto da primeira vez, como da segunda, que tinha acompanhado os brancos, àquele diligência, que êles eram máus pois que a sua nação se rendera logo à primeira instância dos brancos, e -que êles se desenganassem inteiramente, que a não aceitarem as proposições, que thes nham feito, e a continuarem nos seus insultos, e rapinas, que todo o poder dos brancos acompanhado dêle Caiapó, e das mais nações Acrôas, Chacreabás, Carajás e Javaés, recairia sôbre êles, e castigariam por sua vez a sua rebeldia: ao que respondeu o Xavante: que nada disso era preciso, pois que eles se davam por persuadidos, e que iam capacitar a sua nação a entrar no futuro estio...

Nos princípios do verão partiram alguns dêstes a encontrar os parentes: porém vendo S. Excelência, que se passava o prefixo tempo, sem ter notícia alguma, poucas esperanças the restaram da sua vinda.

Mas tendo So Excelência encarregado ao Capitão de Dragões José de Melo e Castro a construção de um novo registro nas margens do Rio Tocantins, vizinhanças do Arraial do Pontal, afim de evitar o extravio do ouro desta Capitania para a do Pará, dali avisou o dito Capitão à $S$. Excelência, 
que naquelas alturas se achavam mais de dois mil índios Xavantes ainda receoscs de entrarem; mas tendo thes desvanecido os seus receios, firgindo que S. Excelência o dirigia ali positivamente a recebe-Ios, os puzera a caminho guiados por um soldado Dragão, afim de thes aprontar os mantimentos necessários。 Sua Excelência com essa notícia ficou sumamente satisfeito; e ao mesmo tempo cercado dos maiores cuidados, vendo entrar em uma Capitania tão falha de fôrças como esta semelhante número de gentio, que nunca pensou, nem esperava de uma nação a mais atrevida, em um ano mais estéril de mantimentos, e a Fazenda Real inteiramente exaurida de meios, para poder suprir as indispensáveis despesas.

Estas ponderações agitaram fortemente o espírito de S. Excelência, o.. fêz uma conferência com os decutados da Junta da Fazenda, e as pessoas mais cordatas desta Vila, assentando-se ser conveniente dividir a dita nação em duas aldeias, tanto para bem de subsistência, como para the diminuir - orgulho, que the podia fomentar o seu grande número, formando-se a segunda aldeia nas Salinas, margem do Rio Araguaia, distante da primeira quarenta léguas, e com este projedo mandou S. Excelência fazer ali plantações, meter gados, e dar as mais providências para êste novo estabelecimento.

Desejando S. Excelência evitar aos moradores do caminho o incômodo da passagem do gentio, conhecendo o grande horror que tinham concebido a esta nação, tanto pela sua ferocidade, como pela sua multidão, ordenou se dirigisse a marcha pelas estradas menos povoadas, o que não the foi possível conseguir apesar das suas diligências; pois os que cá se achavarn, os guiavam pelos arraiais, que já conheciam, sendo geral o susto, e'receio dos habitantes... porém é de admirar, que com alguns dias de demora no Arraial do Pilar se passasse de um extremo a outro, convertendo-se todo o susto e horror, em amor e carinho, ..

Além dêstes brindes concorreram os lavradores com mantimentos, não só para a sua hospedagem naquêle arraial, mas ainda para a sua aldeia..

Sua Excelência fêz marchar logo o Alferes Miguel de Arruda e Sá para o arraial de Amaro Leite e recebê-los, e conduzí-los para o lugar do seu destino; e ao mesmo tempo incumbiu ao Sargento-mór da Cavalaria Alvaro José Xavier de ir esperar a dita nação na paragem, onde se divide o caminho para as Salinas, encarregado de lhe propôr a dita divisão, em que S. Excelência tinha o maior empenho; igualmente encarregou ao Capitão de Dragões José Pinto da Fonseca de marchar para a aldeia de Pedro III e dar tôdas as providências necessárias para 
receber, e aldear o dito gentio, acelerando, quanto the fôsse possível, as plantações, e construções de algumas fábricas nece šsárias a assegurar a subsistência dos novos hospedes.

o Sargento-mór apesar de tôdas as suas diligências nada code conseguir no tocante a divisão, no que não quizeram convir por modo alsum, dizendo que quando se determinaram a abandonar as suas brenhas, era para viverem com os brancos, e não em tanta distância, quanto era a das Salinas, cujo clima era bem dêles conhecido por pouco sadio, e muito infestado de mosquitos.

\section{$(\ldots)$}

Sua Excelência se dispôs a dar tôdas as providências, que the foram possíveis, renovando as suas ordens ao Capitão de Dragões José da Fonseca, afim de que puzesse todos os seus esforços em providenciar todo o preciso, para hospedar tão grande família, que se dispunha a entrar naquela aldeia; contendo-os ali, não the permitindo o virem inundar a Capital, como pretendiam...

Finalmente com seis meses de marcha, dentro da Capitania por não the permitir o seu grande peso andarem mais de meia légua por dia pelo grande número de velhos, cegos, e estropiados, e infinitas crianças carregando uns, e outros sôbre seus ombros; nesta figura entrou esta grande familia na aldeia de Pedro III, no dia 7 de janeiro de 1788, cuja multidão jămais se tinha visto nesta Capitania, além do resto, que ainda se espera entrar no estio vindouro.

... ali se contiveram, e conservam há trës meses; não vindo à Capital, senão o maioral com os chefes mais principais da nação, na conformidade das ordens de S. Excelência, que se empenhou em recebê-los com uma pompa capaz de the impôr respeito, e fazerem das nossas fôrças muito diferente conceito. Sua Excelência tratou, e brindou ao maioral de tal sorte, que se recolheu à sua aldeia tão contente, como satisfeito, publicando nela os benefícios recebidos; e fazendo imediatamerite uma fala à nação, persuadindo-a das nossas boas intenções a seu respeito, e animando-os ao trabalho, como S. Excelência the tinha recomendado, para cujo fim the fazia entrega das ferramentas, que para êles tinha recebido, tudo se ouviu e aceitou com mil demonstrações de júbilo, e festejo ao seu uso.

Vendo S. Excelência a grande multidão de inocentes, que esta nação conduziu, e desejoso de vê-los alistados por filhos da Igreja, ordenou logo ao vigário da Freguesia de Pilar, e cujo pastor pertence êste novo rebanho, para ir àquela aldeia imprimir o caráter espiritual do santo Batismo... 
.. que conseguida esta felicidade, grandes vantagens devemos esperar do seu braço forte, fazendo mais em pou cas horas, do que os negros em fruitos dias.

Tendo o nosso Excelertíssimo General a satisfação de ter libertado os povos desta Capitania de outras tantas feras, que the devoravam as entranhas; e ao mesmo tempo a incomparável glória de ter grangeado à Igreja igual número de filhos, com outiros tantos vassálos ao Império Português:"

$$
\begin{aligned}
& \text { (FREIRE, "Relação da Conquista } \\
& \text { do Gentio Xavante", } \\
& \text { RAVAGNAII, 1978, p.42-51)。 apud }
\end{aligned}
$$

Em seguida, a aldeia foi cerimonialmente entregue aos índios, tendo proferido discurso o Capităo de Dragões José Pinto da Fonseca e o chefe Xavante, Arientomô-Iaxêqui, proferìdo um juramento formal. A data da cerimônia foi.13 de janeiro de 1788 e vários autores consideram a entrada dos índios em Carretão esta data. Segue a transcrição do discurso do representante do governador e o juramento do maioral Xavante:

"O nosso capitão grande a quem os brancos, os negros e as nações da vossa côr, xacriabás, carajás, javaezes e caiapós, obedecem, aquelle mesmo que, compadecido das vossas misérias, nos enviou a convidar-vos nas vossas próprias terras, afim de deixardes a vida errante, em que viveis como indomáveis feras, e virdes entre nós gozar dos commodos que vos offerece a sociedade civil, debaixo da muito alta, poderosa e maternal proteç̧ão de nossa augusta soberana, a Senhora D. Maria I, rainha de Portugal, que habita além do grande lado ocea no, me envia aqui a receber-vos, e cumprimentar-vos de sua par te, e segurar-vos as suas boas intenções, offerecendc-vos estes presentes, signaes de una eterna alliança, com que deseja firmar a paz, união e perfeita amizade, com que reciprocamente nos devemos tratar.

Ao mesmo temno, em nome do vosso capitão grande, vos faço entrega d'esta aldêa, que para vosso domicilio tem destinado, a qual pertencendo-vos de hoje em diante como propria, também sereis perpetuos possuidores d'estes dilatados campos, riós e bosques, até onde vossas vistas possam alcançar. 
$E$, para que o nosso capitão grande fique assaz persuadido de vossa resolução, sabendo de sciencia certa a fé, obediencia e inteira sujeição que a sua pessoa tributais, e à nossa imvicta e amabilissima rainha, se faz preciso que firmais a vossa fidelidade com o juramento de uma perpetua, inalterável e eterna alliança."

$$
\text { (AIAANCASTRE, 1864, p. 335-336) }
$$

$$
\text { o Juramento a que o "maioral" dos Xavante foi }
$$
obrigado a fazer, está assim registrado:

"Arientomô-Iaxê-qui, maioral da nação Chavante de Quá, em nome de toda a minha nação, juro e prometo a Deus de ser, como já sou de hoje em diante, vassallo fiel da rainha de Portural, Maria I, a quem reconheço por minha soberana senhora, mãi e protectora; e de ter perpetua paz, união, e eterna alliança com os brancos; o que assim me obrigo a cumprir e guardar para sempre. Aldêa de Pedro III, 13 de janeiro de 1788 . - Arientomô-Iaxê-qui - O. vigário de Crixá, João Baptista Gervazio Pitaluga - 0 sagento mór, Alvaro José Xavier - o Sargento mór, Bento José Marques - o capitão de Dragões, José Pinto da Fonseca - O alferes de pedestre Miguel de Arruda e Sá - O capitão, Manoel José de Almeida."

-(Idem, p. 336)。 